\title{
\#USGS science for a changing world
}

\section{Geologic Studies in Alaska by the U.S. Geological Survey, 1999}

U.S. Geological Survey Professional Paper 1633

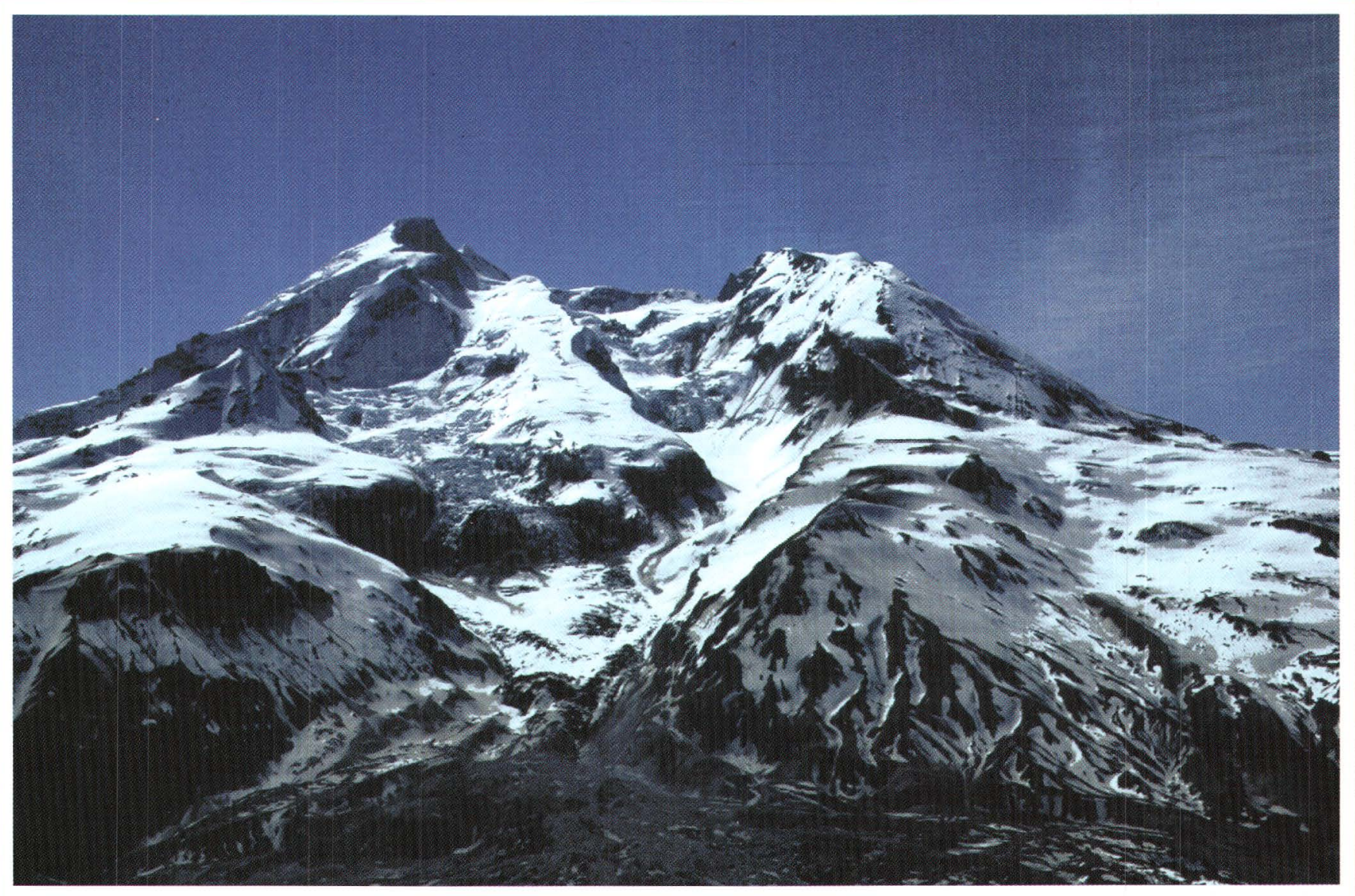


Cover. Redoubt, a massive snow- and ice-covered 10,200-ft-high volcano located 105 miles southwest of Anchorage, has erupted three times in the past 100 years $(1902,1966-67,1989-90)$. The last eruption was characterized by repeated episodes of lava-dome growth and subsequent destruction. The resulting pyroclastic flows mixed with ice and snow to create massive lahars, several of which completely inundated the 1-mile-wide Drift River valley and flowed 25 miles to enter the sea. The largest flows-comparable to the average discharge of the Mississippi River-swept past and through the Drift River Oil Terminal, threatening the oil storage and loading facility. View is of north flank. Photograph by C.A. Neal, June 4, 1996. 


\section{Geologic Studies in Alaska by the U.S. Geological Survey, 1999}

Edited by Larry P. Gough and Frederic H. Wilson

U.S. Geological Survey Professional Paper 1633 


\section{U.S. Department of the Interior}

Gale Norton, Secretary

\section{U.S. Geological Survey \\ Charles G. Groat, Director}

First printing March 2001

For sale by U.S. Geological Survey, Information Services

Box 25286, Denver Federal Center

Denver, CO 80225

This publication is also available online at:

http://geology.cr.usgs.gov/pub/ppapers/p1633/

Any use of trade, product, or firm names in this publication

is for descriptive purposes only and does not

imply endorsement by the U.S. Government 


\section{Contents}

Introduction

By Larry P. Gough and Frederic H. Wilson 1

\section{HAZARDS}

Redoubt Volcano and the Alaska Volcano Observatory, 10 years later

By Game McGimsey

Snowy Mountain: A pair of small andesite-dacite stratovolcanoes in Katmai National Park

By Wes Hildreth, Judy Fierstein, Marvin A. Lanphere, and David F. Siems 13

\section{GEOLOGIC FRAMEWORK}

The Insular-Intermontane suture zone (IISZ) of the western Coast Mountains of southeastern Alaska and British Columbia and the Adria-Europe suture zone (AESZ) of southern Europe-General description and comparison of global-scale tectonic features

By David A. Brew 35

Quaternary geology, Cold Bay and False Pass quadrangles, Alaska Peninsula

By Frederic H. Wilson and Florence R. Weber 51

Reconnaissance geology north of the Hoholitna River, Taylor Mountains D-1 1:64,360-scale quadrangle, southwestern Alaska

By Robert B. Blodgett and Frederic H. Wilson 73

Use of Landsat MSS and TM imagery to improve reconnaissance geologic mapping in the Ruby quadrangle, west-central Alaska

By Keith A. Labay, Frederic H. Wilson, and Kuuipo A. Burleigh 83

\section{ENVIRONMENT AND CLIMATE}

Holocene vegetation history of the northern Kenai Mountains, south-central Alaska

By Thomas A. Ager.

Biogeochemistry of arsenic and cadmium, Fortymile River watershed, east-central Alaska

By Larry P. Gough, James G. Crock, Warren C. Day, and Jim Vohden. 109 


\section{RESOURCES}

Geochemistry of lithologic units, Fortymile River study area, east-central Alaska

By Bruce M. Gamble, Warren C. Day, and Mitch W. Henning .

\section{BIBLIOGRAPHIES}

U.S. Geological Survey reports on Alaska released in 1999

Compiled by John P. Galloway. 135

Reports about Alaska in non-USGS publications released in 1999 that include USGS authors

Compiled by John P. Galloway. 139 


\section{Contributors to this Professional Paper}

\section{Anchorage}

Burleigh, Kuuipo

Gamble, Bruce M.

Gough, Larry P.

Labay, Keith A.

McGimsey, Robert G. (Game)

Wilson, Frederic H.

U.S. Geological Survey

4200 University Dr.

Anchorage, AK 99508-4667

Henning, Mitchell W.

Alaska Department of Natural Resources 550 W.7th Ave., Suite 900B

Anchorage, AK 99501-3577

\section{Denver}

Ager, Thomas A., Mail Stop 980

Crock, James G., Mail Stop 973

Day, Warren C., Mail Stop 973

Siems, David F., Mail Stop 973

U.S. Geological Survey

P.O. Box 25046, Mail Stop

Denver Federal Center

Denver, CO 80225

\section{Fairbanks}

Vohden, James

Alaska Department of Natural Resources

3700 Airport Way

Fairbanks, AK 99709

Weber, Florence R.

U.S. Geological Survey

794 University Ave.

Fairbanks, AK 99709-3645

\section{Menlo Park}

Brew, David A., Mail Stop 901

Fierstein, Judy, Mail Stop 910

Galloway, John P., Mail Stop 901

Hildreth, Edward W. (Wes), Mail Stop 910

Lanphere, Marvin A., Mail Stop 937

U.S. Geological Survey

345 Middlefield Road, Mail Stop _

Menlo Park, CA 94025

\section{Others}

Blodgett, Robert B.

1135 N.W. Circle Blvd.

Corvallis, OR 97330 



\title{
Geologic Studies in Alaska by the U.S. Geological Survey, 1999
}

\author{
Edited by Larry P. Gough and Frederic H. Wilson
}

\section{Introduction}

\author{
By Larry P. Gough and Frederic H. Wilson
}

The collection of nine papers that follow continue the series ${ }^{1}$ of U.S. Geological Survey (USGS) investigative reports in Alaska under the broad umbrella of the geologic sciences. The series presents new and sometimes preliminary findings that are of interest to earth scientists in academia, government, and industry; to land and resource managers; and to the general public. Reports presented in Geologic Studies in Alaska cover a broad spectrum of topics from various parts of the State (fig. 1), serving to emphasize the diversity of USGS efforts to meet the Nation's needs for earth-science information in Alaska.

The papers in this volume are organized under the topics: Hazards, Geologic Framework, Environment and Climate, and Resources. This organization is intended to reflect the scope and objectives of USGS geologic programs currently active in Alaska. The two Hazards studies discuss volcano-related topics in the seismically active southcentral Alaska region. The first paper revisits the eruptive events of Redoubt Volcano that occurred more than a decade ago and the subsequent development of the Alaska Volcano Observatory (AVO). This treatise documents the historic impact of this eruption and briefly summarizes the state of our knowledge of the other Cook Inlet, Alaska Peninsula, and Aleutian Island volcanoes. Finally, it discusses the recent role that AVO has had in seismic station installation and hazard assessment at volcanically active sites throughout the world. The second paper discusses the eruptive history of Snowy Mountain in the upper Alaska Peninsula. Because subsets of its 25-30 lava flows erupted as packages in short episodes, calculation of the volcano's lifetime average volumetric eruption rate is problematic. A portion of the cone was hydrothermally weakened and collapsed in the late Holocene producing a $22-\mathrm{km}^{2}$ debris avalanche.

Geologic Framework studies provide background information that is the scientific basis for present and future earth science investigations. The first paper compares and contrasts the Insular-Intermontane suture zone (IISZ) of southeast Alaska with the Adria-Europe suture zone (AESZ) of Switzerland and Hungary. The study develops the hypothesis that the zones have distinct differences as well as similarities and neither is a simple lithotectonic terrane boundary. The second paper discusses the relation among volcanic, glacial, and tectonic activity in the Cold Bay and False Pass 1:250,000-scale quadrangles on the Alaska Peninsula. During Pleistocene time, continental-shelf glaciations and two massive volcanic centers were the dominant controls over landscape development. The third paper gives detailed geologic information for Paleozoic rocks within the Taylor Mountains D-1 quadrangle portion of the Holitna

\footnotetext{
1 From 1975 through 1988, Geologic Studies in Alaska was published as a series of USGS Circulars, which were titled "The United States Geological Survey in Alaska: Accomplishments during 19xx." From 1989 to 1994 , the series was published as the more formal USGS Bulletins. As a result of a reorganization in 1995 of USGS publications, the series has been published as USGS Professional Papers.
} 
Lowland of southwestern Alaska. Because of the excellent preservation of megafossils, these Silurian and Ordovician strata lend themselves to detailed statigraphic investigations. Further, low thermal alteration indices of this area have made them a potential target of petroleum exploration. The final report in this section discusses the development of a new spectral enhancement approach for interpreting Multispectral Scanner (MSS) and Thematic Mapper (TM) satellite images. This technique enhances the use of remote sensing data in identifying geologic units in areas that have been poorly investigated. This study used this technique to better define the distribution of a JMtu (mafic, ultramafic, and sedimentary) unit and a PzZrqs (pelitic and quartzitic schist) unit.

Environment and climate studies are the emphasis of two papers. One presents the first radiocarbon-dated postglacial vegetation history of the Kenai Mountains of southcentral Alaska. This reconstruction is the result of the analysis of pollen assemblages and peat from sediments collected in Tern Lake and presents a minimum age for deglaciation of these interior valleys at 9,310 $200 \mathrm{yr}$ B.P. Current vegetation, however, developed within the past ca. 2,500 years. A second study discusses the cycling of arsenic and cadmium in sub-arctic boreal forest ecosystems typical of interior Alaska and defines the importance of various natural (geogenic) sources. The transport and uptake into vegetation of these elements from soils developed from loess as well as soils developed from the major rock units is presented. The bioaccumulation of cadmium in willow (Salix sp.) and its potential consequence to the health of browsing animals is discussed.

Papers related to resource issues comprise the topic of the final report. This paper presents a brief statistical summary of the geochemistry of rock samples collected in the east-central portion of the Eagle 1:250,000-scale quadrangle. This study helps define the rock unit source of both resource- and environmental-based chemical elements of interest in the Fortymile mining district.

Two bibliographies at the end of the volume list reports covering Alaska earth science topics in USGS publications during 1999 and reports about Alaska by USGS authors in non-USGS publications during the same period. 


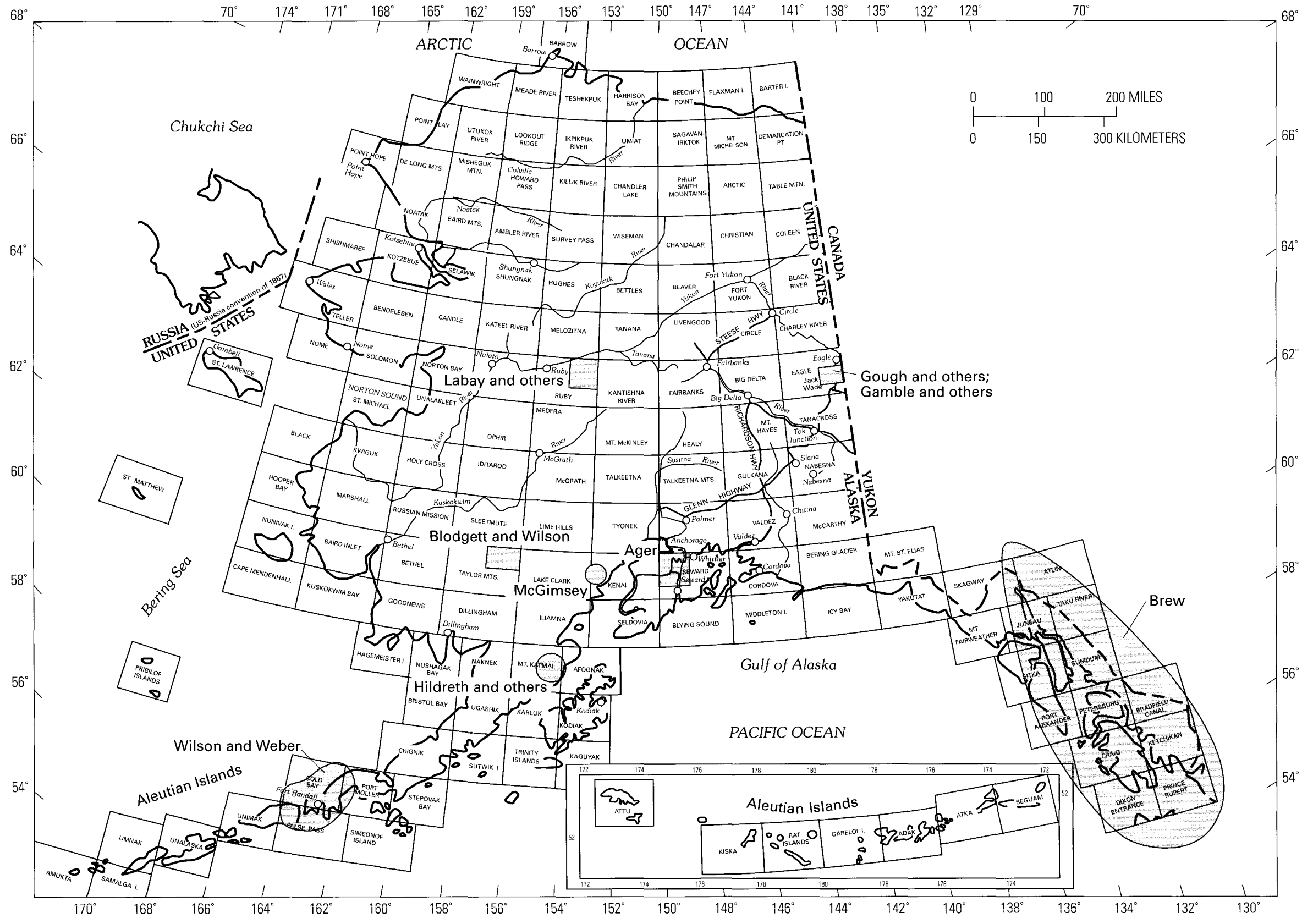

Figure 1. Index map of Alaska showing 1:250,000-scale quadrangles and locations of study areas discussed in this Professional Paper. 



\title{
Redoubt Volcano and the Alaska Volcano Observatory, 10 Years Later
}

\author{
By Game McGimsey
}

The sun was still low on the Alaska horizon late in the morning of December 15, 1989, as the 747-400 jumbo jet carrying 245 people from Amsterdam began its approach into Anchorage International Airport. As the plane descended through 26,000 ft into the regional cloud blanket over Talkeetna, day became night, and an ominous silence gripped the cabin as all four engines automatically shut down and gritty ash and sulfurous gas filled the air. The pilots had descended into a dense ash cloud produced a few hours earlier by an explosive eruption from Redoubt Volcano, 105 miles west of Anchorage (fig. 1). Fortunately, after gliding powerless for 8 frightful minutes and falling nearly $12,000 \mathrm{ft}$ - to within $2,000 \mathrm{ft}$ of the ground-disaster was averted when the engines were restarted and the plane landed successfully in Anchorage (Casadevall, 1994). The eruption of Redoubt Volcano and its impact on aircraft safety ushered in a new era of hazard assessment and volcano monitoring in Alaska.

December 14, 1999, marked 10 years since Redoubt Volcano began a 6-month eruption that disrupted transportation and commerce in south-central Alaska, threatened the Drift River Oil storage and loading Terminal (DROT), and caused more than $\$ 160$ million in economic loss and property damage (Brantley, 1990; Miller and Chouet, 1994). Installation of the Redoubt seismic network was completed only a year prior to the eruption, allowing staff from the newly created Alaska Volcano Observatory (AVO) to monitor the activity and issue warnings. The eruption response propelled AVO from infancy to adulthood.

Prior to 1988, only one of the four Cook Inlet volcanoes was considered seismically monitored-Augustine - where a network was maintained by the University of Alaska Geophysical Institute (UAFGI). A few seismic stations were also maintained on two other volcanoes, Spurr and Iliamna, by U.S. Geological Survey (USGS) seismologists from Menlo Park, Calif., working through the National Earthquake Hazard Reduction Program (J.A. Power, oral commun., 2000). In the vicinity of Redoubt, two UAFGI stations had been operating since the early 1970's (Power and others, 1994). The combined efforts involved about 13 seismic stations. AVO was created in 1988, following the 1986 eruption of Augustine Volcano, to focus Federal and State scientific expertise, monitoring resources, hazard assessment, and eruption response toward the 41 historically active volcanoes in Alaska. Efforts to increase seismic coverage in Cook Inlet began in earnest during the summer of 1988 with installation of three more stations to complete the Redoubt network and additions or upgrades to the equipment on Spurr, Iliamna, and Augustine. The AVO monitoring program at Redoubt began in October 1989 - 2 months prior to the eruption - as the new stations became operable.

When Redoubt erupted, AVO consisted of a skeletal staff of about one full-time and three to five part-time individuals who relied primarily on occasional reports from pilots and local observers to learn of volcanic activity outside of the Cook Inlet area. During the Redoubt eruption response, the juvenile AVO became a fully functional organization with permanent staff, new and upgraded equipment, and a resolve to fulfill its mission of monitoring all of Alaska's active volcanoes. With an average of one to two eruptions per year in the Aleutian volcanic arc (46 documented eruptions since 1986), and cargo and passenger flights steadily increasing along the North Pacific air corridor (fig. 2; table 1), the need for improved monitoring capabilities beyond Cook Inlet became imperative. In 1996, with Congressional funding provided through the Federal Aviation Administration (FAA), AVO expanded its seismic monitoring program to volcanoes down the Alaska Peninsula and in the Aleutian Islands. At the close of 1999, AVO had about 103 seismic stations in 13 networks capable of monitoring the seismicity at 21 volcanoes (fig. 3). Daily analysis of satellite imagery spanning the north Pacific from the Kurile Islands to the Cascade Range of the United States (fig. 4) allows the tracking of ash plumes and the surveillance of thermal activity at restless and erupting volcanoes. Ground-based geologic studies have accompanied the seismic installations, thus providing the basis for hazard evaluation and interpretations of future and ongoing eruptive activity.

AVO staff have gained valuable experience in the 10 years following the Redoubt eruption. In addition to responding to an average of one to two eruptions and two to three volcanogenic seismic crises (intense seismic swarm beneath a volcano that may or may not culminate in an eruption) in the Aleutian arc per year, including the 1992 eruption of Spurr Volcano and the 1996 seismic swarm at Iliamna Volcano, AVO scientists have participated in seismic station installation and hazard assessment at Pinatubo (Philippines), Soufriere Hills (Montserrat), Guagua Pichincha (Ecuador), Tungarahua 


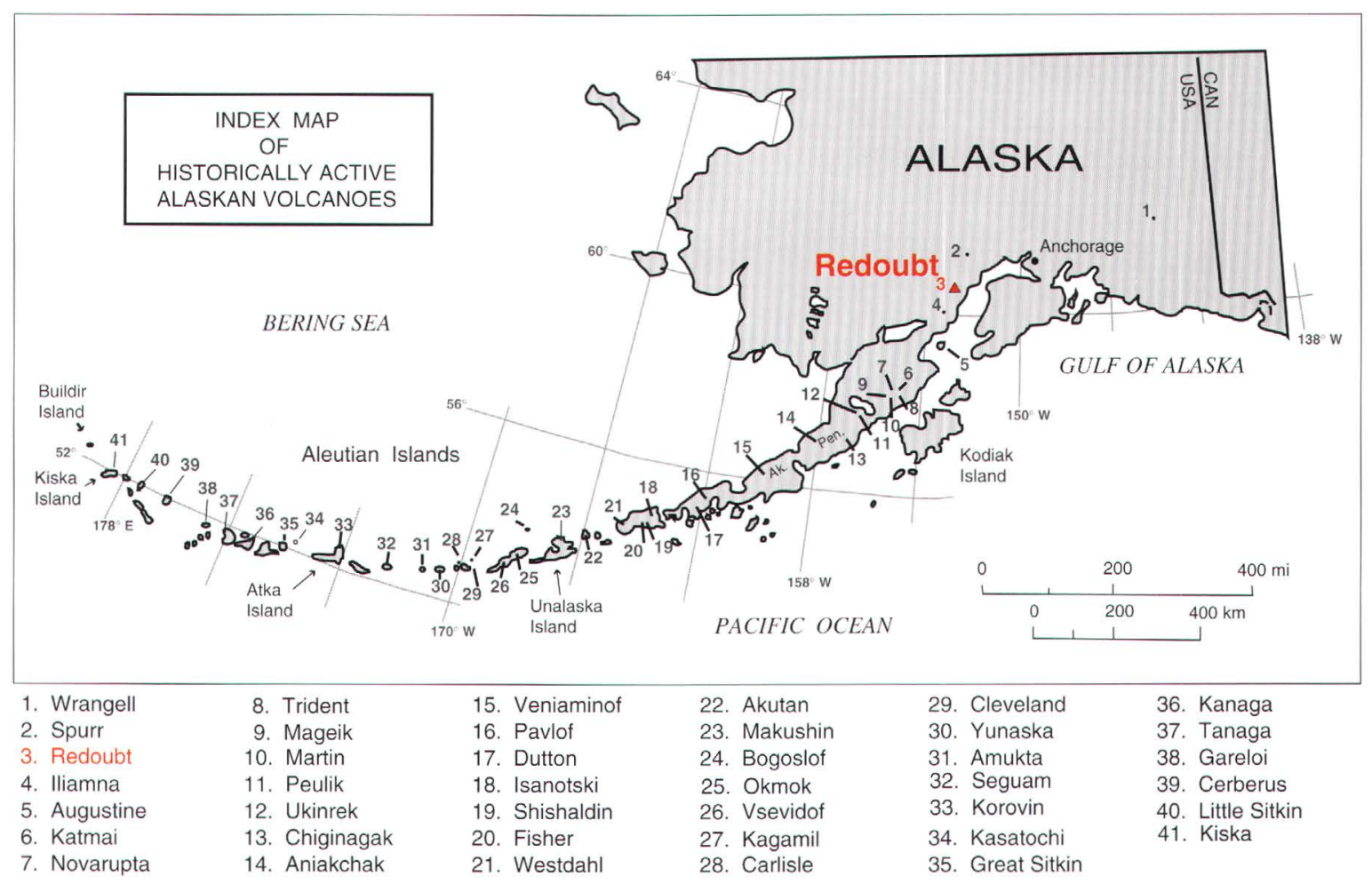

Figure 1. Location of historically active volcanoes in Alaska (Miller and others, 1998).

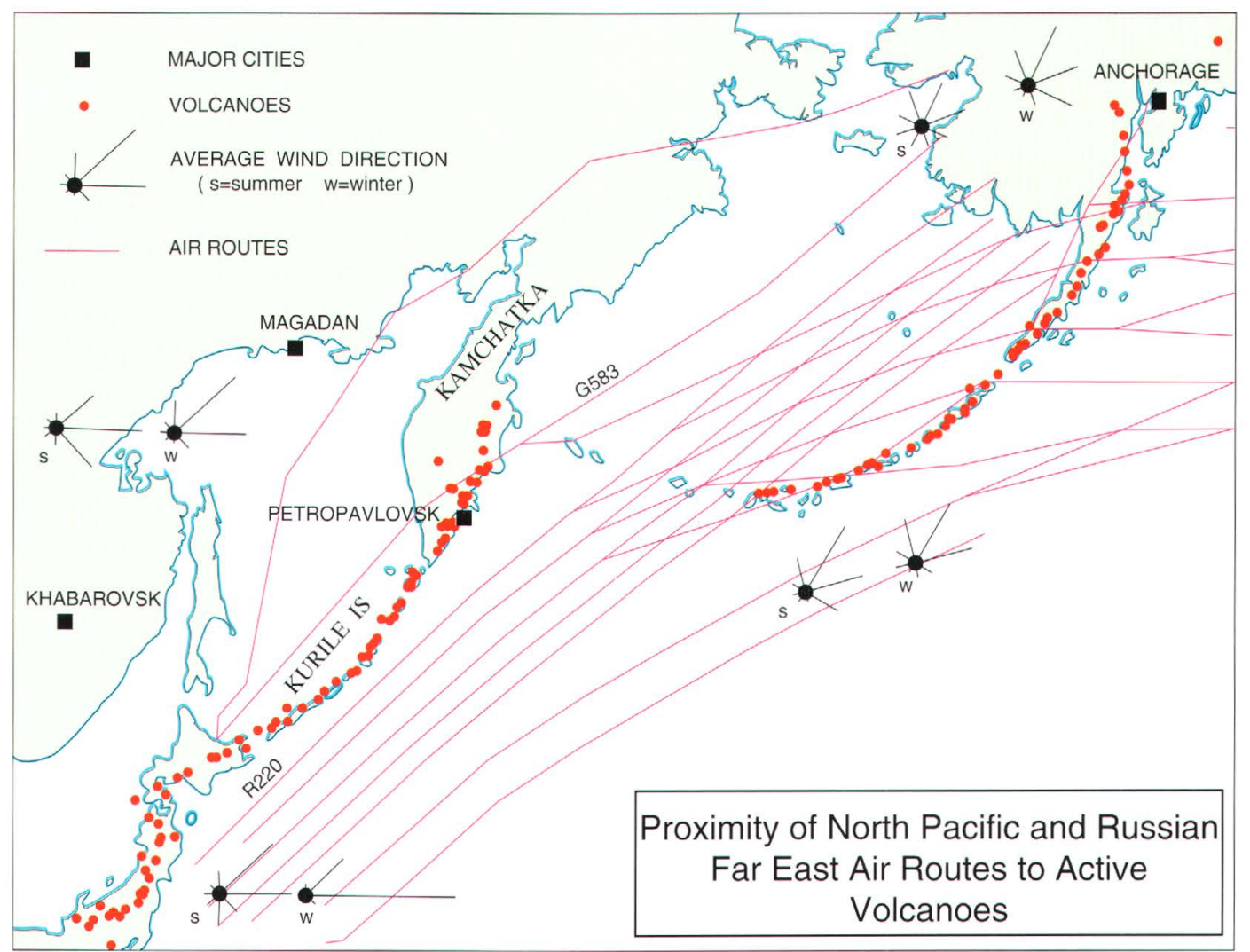

Figure 2. North Pacific (NOPAC) air routes and the 100 active volcanoes in Alaska, Kamchatka, and the Kurile Islands; windrose diagrams show that most of these air routes are downwind or cross the belt of active volcanoes. In 1998, more than 20,000 passengers and millions of pounds of cargo were being transported daily over these routes, including more than 90 percent of the all-cargo flights between Asia and North America. From Miller and Casadevall (2000). 

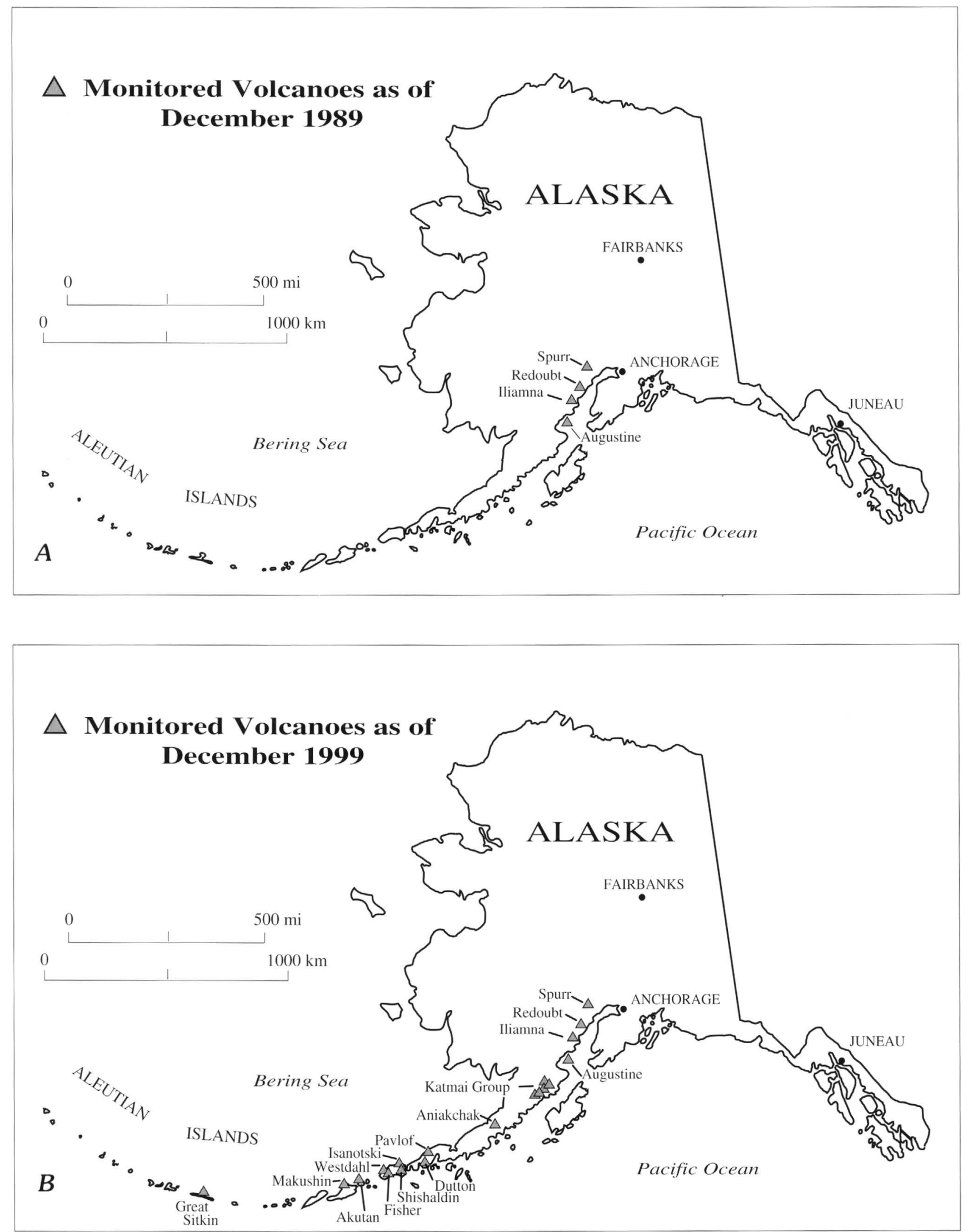

Figure 3. A, Seismically monitored volcanoes in Alaska as of 1989. B, Seismically monitored volcanoes in Alaska as of 1999. The Katmai group network monitors seven closely spaced young volcanic centers: Griggs, Katmai, Novarupta, Trident, Mageik, Martin, and Snowy. 


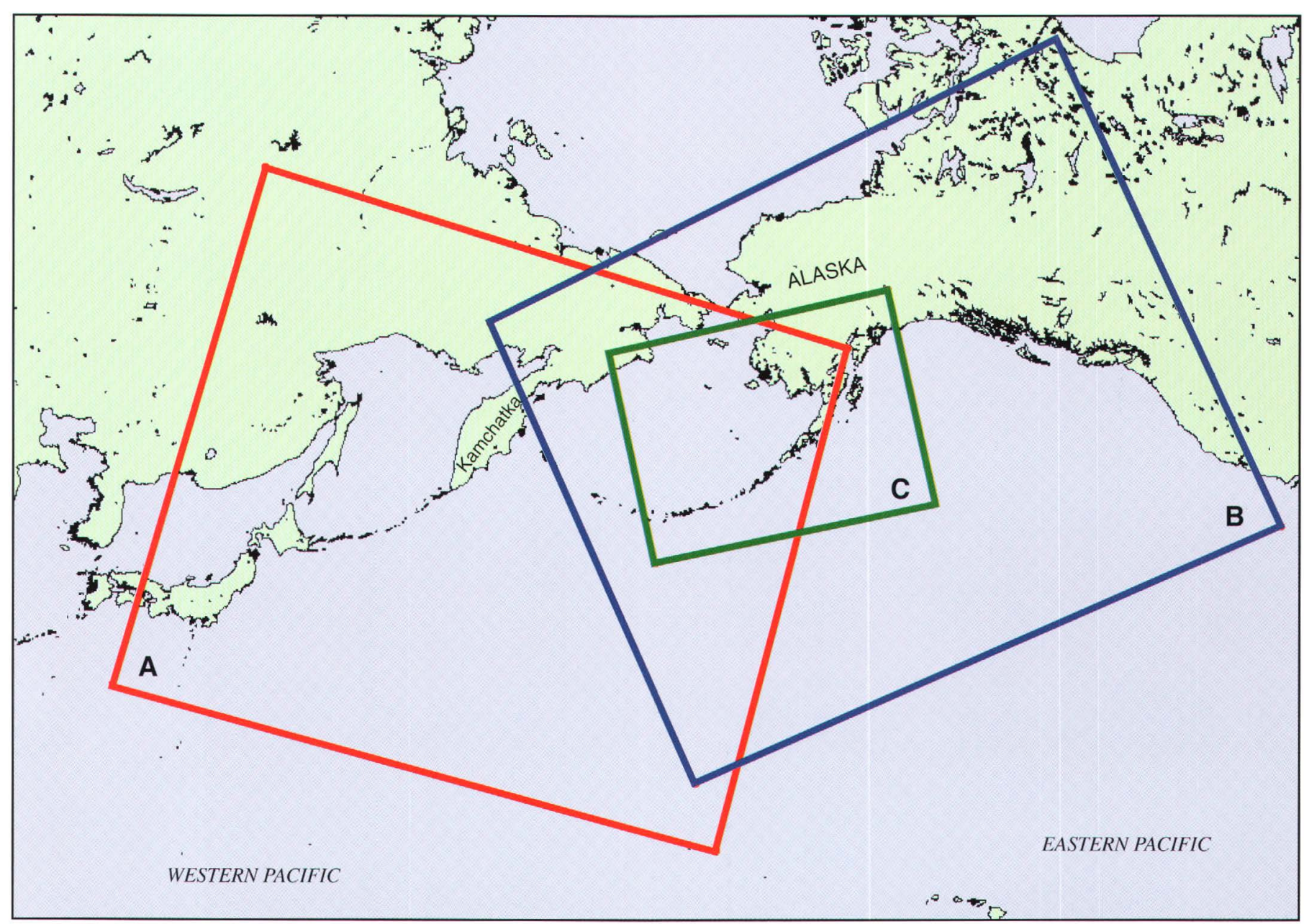

Figure 4. Map showing AVO satellite coverage used to monitor volcanic activity. Box A shows Geostationary Meteorologic Satellite coverage, 8-km resolution, 24 images/day. Box B shows Geostationary Orbiting Environmental Satellite (GOES) coverage, 8-km resolution, 48 images/day. Box C shows GOES, daytime only, 2-km resolution, 48 images/day in summer and 10 images/day in winter; polar orbiting Advanced Very High Resolution Radiometer satellite coverage is $1 \mathrm{~km}$ resolution, 4 images/day of the western Pacific (Kamchatka), and 10 images/day of the eastern Pacific (Alaska).

Table 1. Air traffic (number of flights) along the North Pacific and Russian Far East air routes.

[Data courtesy Gail Ferguson, FAA Anchorage Center Traffic Management Supervisor, oral commun. ND, no data. Air traffic is projected to increase by a factor of 3 by the year 2017 (Miller and Casadevall, 2000)]

\begin{tabular}{ccc}
\hline \multirow{2}{*}{ Year } & \multicolumn{2}{c}{ Number of flights } \\
\cline { 2 - 3 } & $\begin{array}{c}\text { North Pacific } \\
\text { air routes }\end{array}$ & $\begin{array}{c}\text { Russian Far East } \\
\text { air routes }\end{array}$ \\
\hline 1990 & 39,800 & ND \\
1995 & 48,324 & 1,039 \\
1999 & 62,009 & 5,774 \\
\hline
\end{tabular}

(Ecuador), and several restless volcanoes in Nicaragua. At this writing, AVO has about 17 full-time scientists and technicians and 27 part-time staff divided between offices in Anchorage and Fairbanks.

Ten years after the last eruption at Redoubt, snow and ice accumulation have refilled the upper Drift Glacier canyon on the north flank and nearly buried the lava dome emplaced in the summit crater by the last eruption (figs. $5 A, 5 B$ ). A new glacial tongue extends down from the canyon and has merged with, and overridden, the beheaded piedmont lobe of Drift Glacier (figs. 5B). Vegetation has reclaimed the lower flanks, tributary valleys, and Drift River valley walls, mostly covering the proximal tephra accumulations (figs. $5 \mathrm{C}$ ), which were as deep as $25 \mathrm{~cm}$. Rust Slough, which once threatened oil storage tanks at DROT when the Drift River changed course during one of the early eruption-induced mud flows, is now sediment filled and readjusted to a seasonal braided flow regime. As surface vegetation gains a foothold, only the dozens of acres of dead spruce trees - trunks buried as deep as $2 \mathrm{~m}$-remain as a testament to the muddy flood waters that once inundated the area. Reinforced dikes now guard the storage tanks and an 

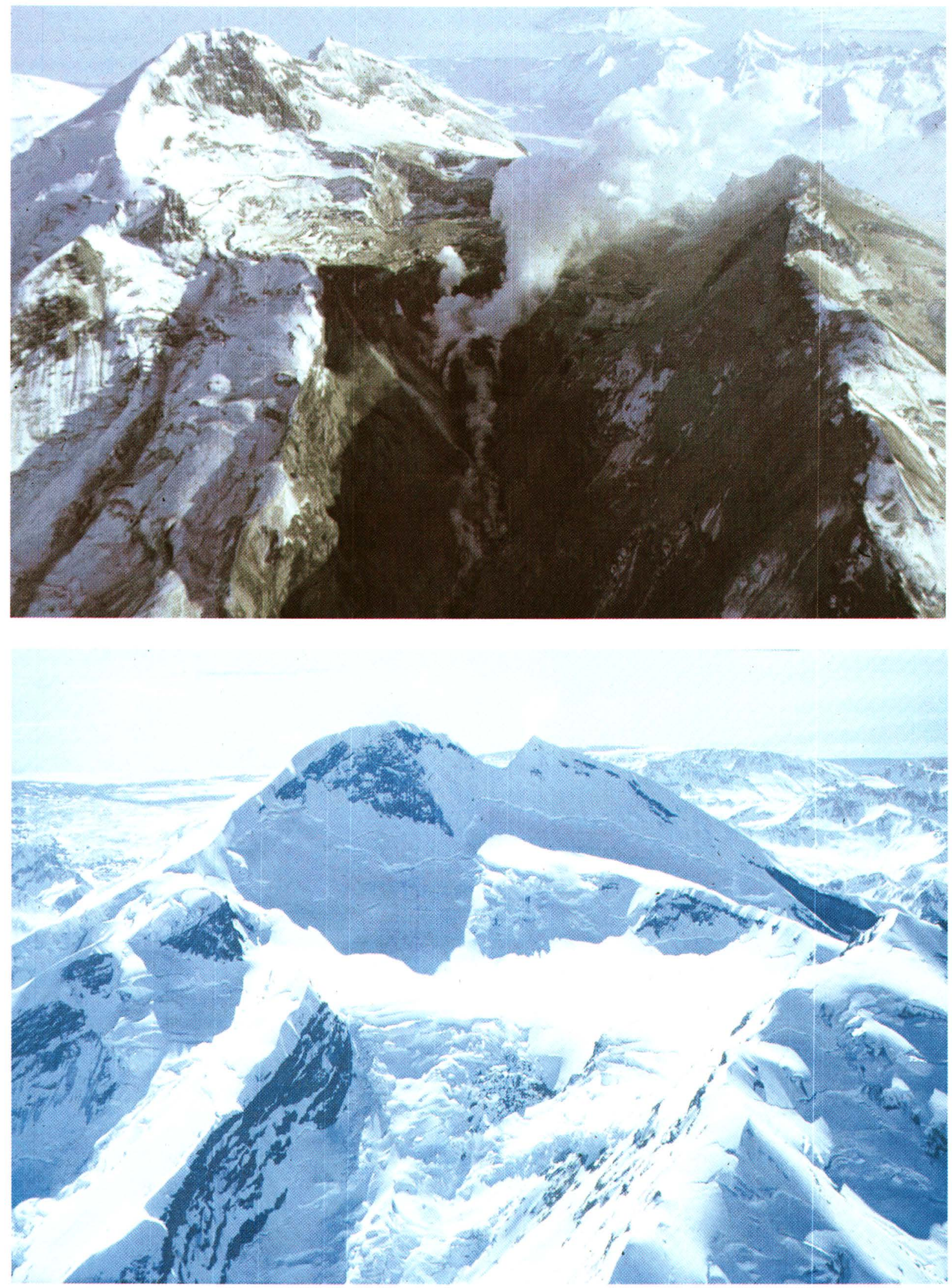

Figures 5A. Redoubt Volcano, north flank. Snow and ice accumulation in the summit crater and upper canyon of Drift Glacier. Photo on top taken April 11, 1990; photo on bottom taken September 28, 1999. 

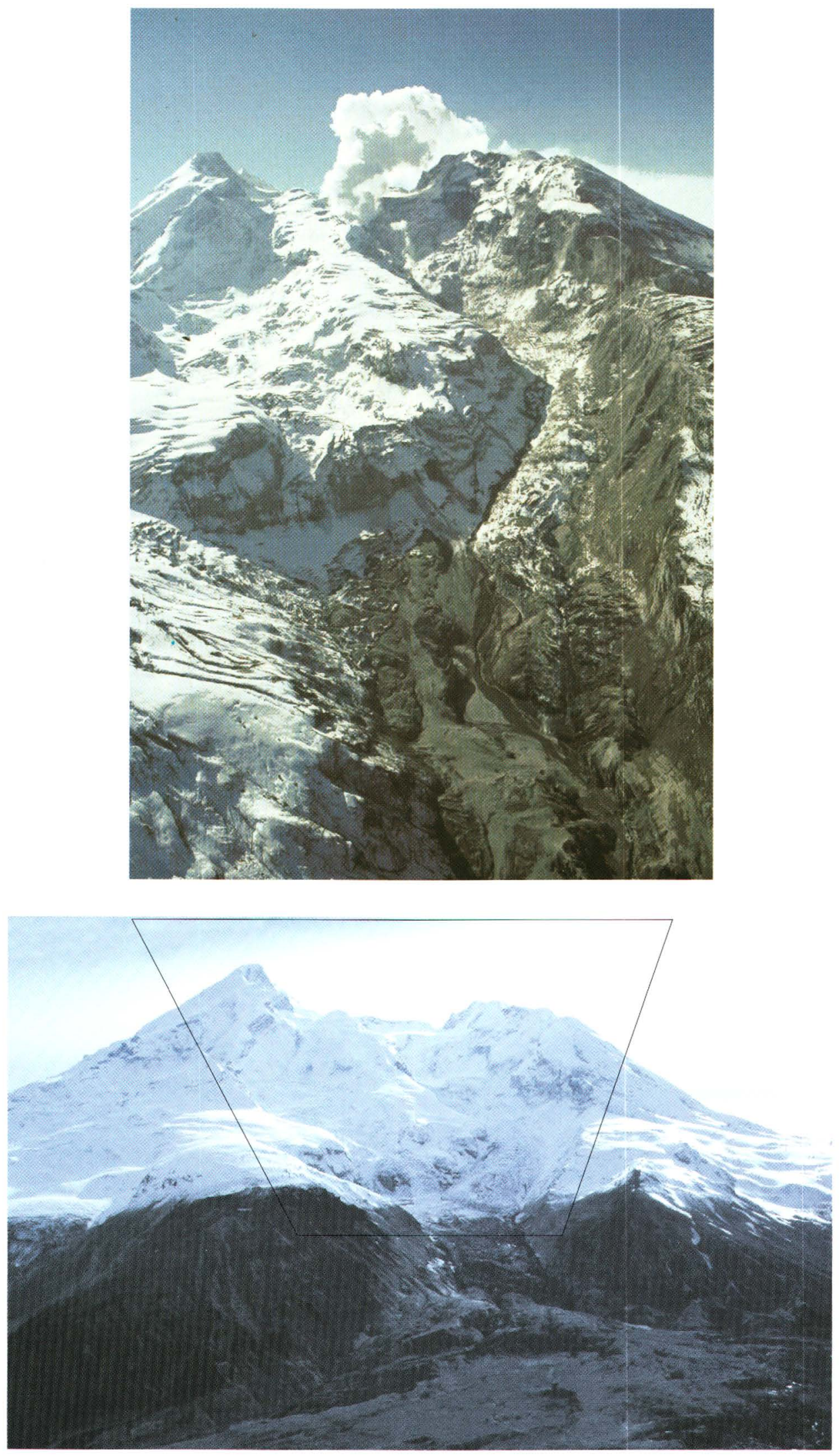

Figures 5B. Upper canyon of Drift Glacier. Photo on top taken on April 25, 1990 (Steve Brantley); photo on bottom taken September 28, 1999. Inset box shows approximate area shown in top photo. Note the advancing glacial tongue (immediately below box) that merges with, and laps onto, the piedmont lobe of Drift Glacier. 



Figures 5C. Lower north flank and piedmont glacier. Photo on top, taken May 30, 1990, shows damage to vegetation from 25 $\mathrm{cm}$ of tephra accumulation. Photo on bottom, taken September 28, 1999, shows revegetation. Inset box shows area portrayed in top photo. 
elevated "safe" house has been constructed at DROT to protect personnel from high water. The lower Drift River has reestablished its main channel to Cook Inlet and the upper and middle sections of Drift River continue to adjust and redistribute the massive amount of sediment and debris delivered during the eruption.

The seven-station seismic network at Redoubt continues to record normal background seismicity (approximately one to two magnitude- 0.5 and higher volcanic earthquakes per week, a level sustained since $1991-\mathrm{S}$. McNutt, oral commun., 2000). Fumaroles on and around the dome still emit steam, which occasionally forms a wispy cloud over the summit. These steam clouds can be seen from Anchorage and the Kenai Peninsula during favorable weather conditions and often prompt calls to AVO from concerned citizens.

Due largely to the efforts of AVO during the past 10 years, aircraft traversing Alaskan skies are far less likely to plunge into a gritty ash cloud. As for Redoubt, the volcano presently sleeps under the watchful eyes of AVO. With three eruptions during the past 100 years, Redoubt will likely wake from its slumber sometime during the new century and once again put AVO to the test.

Reviewers: J. Paskievitch, C. Searcy

\section{References Cited}

Brantley, S.R., ed.,1990, The eruption of Redoubt Volcano, Alaska, December 14,1989-August 31, 1990: U.S. Geological Survey Circular $1061,33 \mathrm{p}$.

Casadevall, T.J., 1994, The 1989-1990 eruption of Redoubt Volcano, Alaska: Impacts on aircraft operations: Journal of Volcanology and Geothermal Research, v. 62, p. 301-316.

Miller, T.P., and Casadevall, T.J., 2000, Volcanic ash hazards to aviation, in Sigurdsson, H., Houghton, B.F., McNutt, S.R., Rymer, H., and Stix, J., eds., Encyclopedia of Volcanoes: Academic Press, p. $915-930$.

Miller, T.P., and Chouet, B.A., 1994, The 1989-1990 eruptions of Redoubt Volcano: An introduction: Journal of Volcanology and Geothermal Research, v. 62, p. 1-10.

Miller, T.P., McGimsey, R.G., Richter, D.H., Riehle, J.R., Nye, C.J., Yount, M.E., and Doumoulin, J.A., 1998, Catalog of the historically active volcanoes of Alaska: U.S. Geological Survey Open-File Report 98-582, $104 \mathrm{p}$.

Power, J.A., Lahr, J.C., Page, R.A., Chouet, B.A., Stephens, C.D., Harlow, D.H., Murray, T.L., and Davies, J.N., 1994, Seismic evolution of the 1989-1990 eruption sequence of Redoubt Volcano, Alaska: Journal of Volcanology and Geothermal Research, v. 62, p. 69-94. 


\title{
Snowy Mountain: A Pair of Small Andesite-Dacite Stratovolcanoes in Katmai National Park
}

\author{
By Wes Hildreth, Judy Fierstein, Marvin A. Lanphere, and David F. Siems
}

\section{Abstract}

Snowy Mountain is a small andesite-dacite volcanic center that originated about $200 \mathrm{ka}$. Eruptions have taken place from two vents $4 \mathrm{~km}$ apart that built contiguous edifices that extensively overlap in age, though only the northeastern vent has been active in the Holocene. Sector collapse of the hydrothermally weakened upper part of the northeastern cone in the late Holocene produced a $22-\mathrm{km}^{2}$ debris avalanche and left a $1.5-\mathrm{km}^{2}$ amphitheater that was subsequently occupied by a blocky lava dome. Many products of the southwestern vent are olivine-bearing (55.5-62.2 percent $\mathrm{SiO}_{2}$ ), whereas those of the northeastern vent are largely pyroxene dacites (61.7-63.7 percent $\mathrm{SiO}_{2}$ ). Estimates of eruptive volume yield $8 \pm 3 \mathrm{~km}^{3}$ for the northeastern edifice, $5 \pm 2 \mathrm{~km}^{3}$ for the southwestern, and $13 \pm 4 \mathrm{~km}^{3}$ for the Snowy Mountain center as a whole. Only half to two-thirds of this material remains in place on the glacially ravaged skeletal edifices today. Because subsets of Snowy Mountain's 25-30 lava flows erupted as packages in short episodes, calculation of the volcano's lifetime average volumetric eruption rate $\left(0.04-0.09 \mathrm{~km}^{3} / \mathrm{k}\right.$.y. $)$ is a potentially misleading exercise. Nominally, the lifetime rate for Snowy Mountain is similar to that estimated for each of the cones of nearby Trident volcano (fig. 1), but it is 3-10 times smaller than long-term rates for Mounts Mageik and Katmai. Snowy Mountain is typical of the close-set arrays of small cones characteristic of late Quaternary andesite-dacite arc volcanism in the Katmai district.

\section{Introduction}

The Snowy Mountain volcanic center consists of a contiguous pair of andesite-dacite stratocones that straddle the rangecrest of the Alaska Peninsula about $15 \mathrm{~km}$ northeast of Mount Katmai. Snowy Mountain is the only late Quaternary eruptive center along the $30-\mathrm{km}$ stretch of the main volcanic line (fig. 1) that separates the closely grouped Katmai cluster (Hildreth and Fierstein, 2000) from the even closer set chain of four stratovolcanoes that begins with Mount Denison (fig. 1). Built along the preexisting regional drainage divide in a zone of high precipitation, these volcanoes have suffered intense glacial erosion, not only during the Pleistocene but continuously throughout the Holocene. Snowy Mountain itself, rising to an elevation of $2,161 \mathrm{~m}(7,090 \mathrm{ft})$, remains today the source of 10 substantial glaciers (fig. 2). Because glacial ice still covers nearly 90 percent of the edifice, the principal rock exposures are limited to narrow ice-bounded arêtes at higher elevations and ice-scoured lava-flow benches at lower elevations.

Snowy Mountain was named during the National Geographic Society expedition to Katmai in 1917 (Griggs, 1922, p. 131). The name chosen evidently reflected how impressed those explorers were with its extensive mantle of snow and ice as seen from upper Katmai River, which was their closest approach to the edifice and provided a vista similar to that illustrated in our figure 3 . They did not identify the mountain as a volcano.

The region around Snowy Mountain is uninhabited National Park wilderness and access is unusually difficult, even for Alaska. The nearest town is King Salmon, $120 \mathrm{~km}$ to the WNW. Hikers and climbers are exceedingly rare in the mountains northeast of Mount Katmai, but aerial sightseeing has recently become common. In the many bays along Shelikof Strait (fig. 1), commercial fishing boats are common and aircraft-supported camping, sportfishing, poaching, and ranger patrols take place sporadically.

Our attention was initially drawn to Snowy Mountain by the identification of persistent diffuse seismicity on and northwest of the volcano (Ward and others, 1991). We thought it worthwhile to investigate the volcanological nature of the remote edifice as background for interpreting the seismic activity (Jolly and McNutt, 1999). On investigating, we were surprised to find that Snowy Mountain remained one of the least known volcanoes in the entire Aleutian arc. So little work had been done in the area that the regional reconnaissance geologic map of Keller and Reiser (1959) had designated Snowy Mountain as "igneous rocks, undifferentiated," lumping it with deformed volcanic rocks of Tertiary age. In Volcanoes 


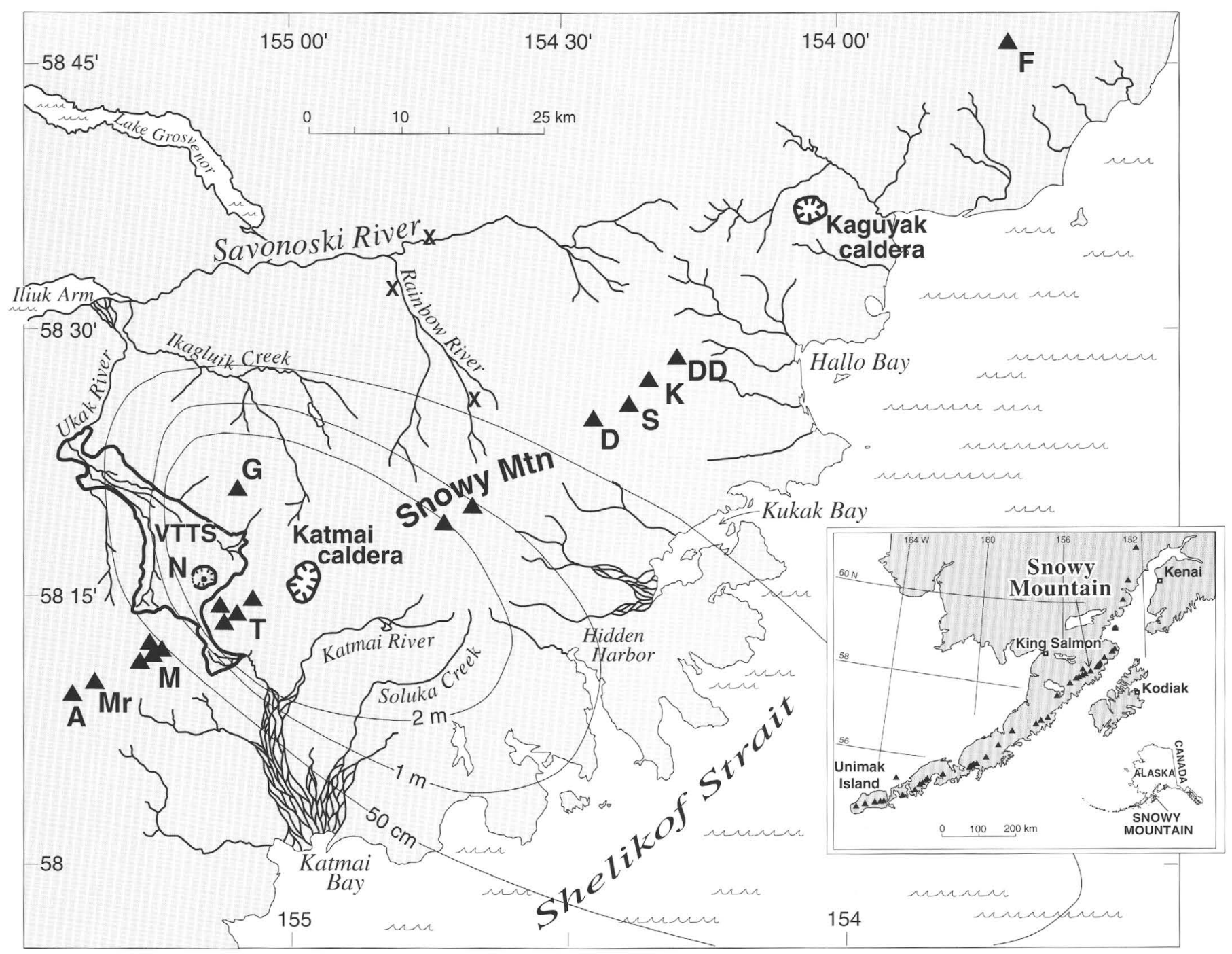

Figure 1. Regional location map showing position of the two Snowy Mountain volcanoes along the late Quaternary volcanic axis, which straddles the drainage divide of this stretch of the Alaska Peninsula. Triangles indicate andesite-dacite stratovolcanoes, identified by letter: A, Alagogshak; Mr, Martin; M, Mageik (cluster of four); T, Trident (cluster of four); G, Griggs; D, Denison; S, Steller; K, Kukak; DD, Devils Desk; F, Fourpeaked. VTTS, Valley of Ten Thousand Smokes ash-flow sheet (outlined area), which erupted at Novarupta (N) in June 1912. Isopachs show thickness of cumulative plinian fallout from Novarupta, originally 1-2 m thick at Snowy Mountain. Were pyroclastic flows or debris flows to originate at Snowy Mountain, after descending glaciers, they could go down Rainbow River, Katmai River, Soluka Creek, or the unnamed drainages ending in Kukak Bay or Hidden Harbor. Bold "X" symbols locate three cutbank exposures of debris-flow deposits mentioned in text.

of the World (Simkin and Siebert, 1994), Snowy Mountain was listed as a stratovolcano, its status given as "Fumarolic," but no further information was provided save location and elevation. The lack of previous attention to Snowy Mountain is especially well illustrated by its entry in Volcanoes of North America (Wood and Kienle, 1990, p. 73) where its purported photograph is actually of Mount Denison and its accompanying map polygon represents an area predominantly of basement rocks. The regional 1:250,000 geologic map of Riehle and others (1993), on the other hand, represents the extent of Snowy Mountain's volcanic rocks rather well, though no additional data are given.
Although our own work is no more than a detailed reconnaissance, we did visit most of the outcrops. Our fieldwork was accomplished entirely by helicopter while in transit between Kaguyak and Katmai volcanoes, where we were conducting more detailed volcanological studies in 1998 and 1999.

\section{Basement Rocks}

Quaternary volcanic rocks of Snowy Mountain overlie three distinctive suites of basement rocks (Riehle and others, 
1993). Most exposures north of the volcano consist of subhorizontal or gently dipping siltstone and sandstone of the Jurassic Naknek Formation (Detterman and others, 1996). Intruding these rocks are several porphyritic granitoid plutons of Tertiary age, into which the glaciers north and northwest of Snowy Mountain have incised spectacular canyons. South and southwest of the volcano, its lava flows rest on altered volcanic rocks that have received little attention. Erupted from several ill-defined centers, these rocks are ordinary arc andesites and dacites, either undeformed or gently warped, slightly to severely altered hydrothermally, and mostly of Neogene (Shew and Lanphere, 1992) and probably in part early Quaternary age.

Like the adjacent volcanic clusters along the Quaternary chain (fig. 1), Snowy Mountain straddles the peninsular drainage divide, having been constructed atop an antecedent rangecrest that had been glacially sculpted from the three basement suites. Although the northwest slope of the range is the steeper at Snowy Mountain, the gentler southeast slope has undergone more severe glacial stripping of the Quaternary volcanic rocks. Moreover, it still retains more extensive ice cover (figs. 2, 3). The asymmetry of erosion may reflect

(a) greater precipitation on the Shelikof Strait (Pacific) side of the range, (b) easier relative erodability of the punky Tertiary volcanic rocks underlying the southerly slopes of Snowy Mountain, and (c) early Pleistocene entrenchment of the northwest-flowing glaciers. Concentration of the northwesterly ice tongues within granite-walled gorges apparently helped preserve the Quaternary lavas on the interfluves between them (fig. 2). Finally, (d) ice-sheet movement northward onto the Alaska Peninsula from the icecap over Kodiak Island (Mann and Peteet, 1994) during Pleistocene glacial maxima could have contributed to greater erosion on the south slope of the volcano.

\section{Ice-Mantled Double Edifice}

Along the rangecrest, the Snowy Mountain volcanic center exhibits three principal summits (figs. 2, 3), Peaks 6770 , 7090 , and 6875. Radial dips, vent facies, and intrusive relationships, however, define just two stratovolcanoes. The ice-filled 6,100-ft saddle between Peaks 6770 and 7090 marks the contact between cones, as clearly defined by opposing stacks of lava flows that dip $20^{\circ}-25^{\circ}$ off those peaks and meet each other at the saddle (fig. 2). Peak 6770 is a large remnant of the northerly shell of the southwestern cone; it stands about $500 \mathrm{~m}$ northwest of its own eroded vent complex (fig. 3; Knob 6600+) and consists of stacked lava flows that dip radially (W., N., and NE.) away. Peak 7090, true summit of Snowy Mountain, is similarly a large ice-ravaged remnant of the westerly shell of the northeastern cone; the peak stands $900 \mathrm{~m}$ west of its vent and its lava flows dip radially from SW. through W. around to N. (fig. 2). Of Snowy Mountain's three rangecrest summits, only Peak 6875 is actually a volcanic vent, being a Holocene lava dome that occupies the crater of the severely eroded northeastern stratovolcano.

The contiguous cones are both predominantly of late Pleistocene age. Judging by its highly and universally eroded condition, the southwestern cone does not appear to have been active in the Holocene. Each volcano has been the source of at least 12-15 andesite-dacite lava flows, a few of which thicken downslope to 50-200 $\mathrm{m}$ distally. The scattered present-day outcrops add up to only $2.4 \mathrm{~km}^{2}$ for the southwestern cone and $6.5 \mathrm{~km}^{2}$ for the northeastern. Interpolation between outcrops and conservative extrapolation downslope suggest original lava-covered areas of $30-40 \mathrm{~km}^{2}$ and $35-45 \mathrm{~km}^{2}$, respectively, not counting probable intracanyon lava tongues subsequently removed by glaciers. Nearly 90 percent of the compound edifice is therefore either currently ice covered or has been glacially stripped.

\section{Southwest Snowy Mountain Edifice}

The Southwest Snowy cone is exposed in 10 discrete areas of outcrop (fig. 2). Most interesting (and probably worthy of further study) is a remnant of the vent complex, preserved as a SSE.-trending ridge $700 \mathrm{~m}$ long and $300-400 \mathrm{~m}$ wide, just south of Peak 6770 (figs. 2-4). The ridge is bounded on most sides by a 200-m-high cliff (fig. 4), the upper half of which consists of chaotic (or locally crudely stratified) coarse breccia, much of it lightly agglutinated or otherwise indurated. On the east face the breccia is cut by several dikes, and on the west face it is intruded from below by a 300-m-wide, steeply jointed intrusive mass, which is probably a remnant of a vent-filling plug (fig. 4). The poorly sorted fragmental debris is block-rich proximal ejecta, not lava-flow breccia, and the blocks range texturally from scoriaceous and partly glassy to vesicle poor and devitrified. Texturally contrasting blocks sampled on the ridgetop are both olivine-andesite (55.6-55.7 percent $\mathrm{SiO}_{2}$ ), the most mafic eruptive material found anywhere at Snowy Mountain.

Immediately north of the vent complex, Peak 6770 exposes a proximal stack of at least six andesitic lava flows on its south-facing 100-m-high scarp (fig. 4). As the largest preserved remnant of the cone, the stack dips radially around the conical sector that swings from west through north to northeast (fig. 2). Most of the cone's surviving mass is concentrated in its northwest buttress, which is ice covered except for two windows of andesite at elevations of 4,700-5,200 ft and $3,800-4,900 \mathrm{ft}$ (fig. 2). These windows expose, respectively, one and three NW.-dipping lava flows. The top flow in the lower window is a plagioclase-rich pyroxene andesite (62.2 percent $\mathrm{SiO}_{2}$ ), similar to the capping flow on the summit, Peak 6770 .

The WNW. arête of Southwest Snowy is an ice-bounded outlier made up of at least three andesitic lava flows (fig. 5 ). It is separated from the main part of the edifice by an arête of gray-green Tertiary andesite as well as by ice. The arête of Southwest Snowy lavas extends northwest from Crag 5720 and broadens into a cliff-bounded mesa (elevation 5,300 


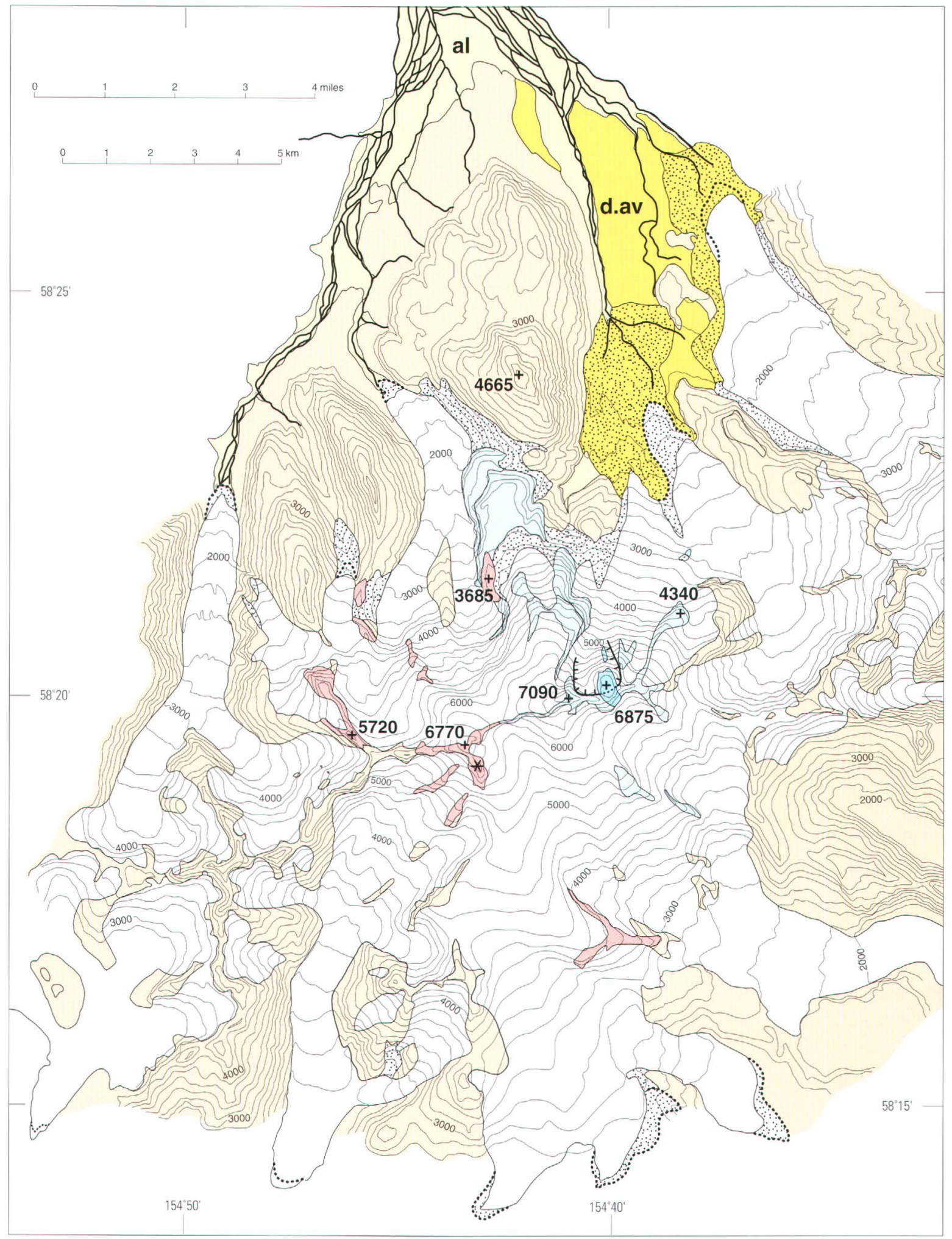

Figure 2A. Simplified geologic map of Snowy Mountain volcanic center. Exposed lavas of Southwest Snowy volcano in red, of Northeast Snowy volcano in blue. Vent complex of former indicated by “*." Holocene lava dome occupying amphitheater (hachured) of latter is darker blue. Most of both cones covered by glacial ice (white). Basement rocks undivided are beige; they are largely Jurassic sedimentary rocks north of the volcanoes and largely Tertiary volcanic rocks to the south, although Tertiary intrusive rocks are also common in both sectors. Active alluvium (al) is pale yellow; debris avalanche deposit (d.av) is bright yellow. Glacial till is stippled. Stippled part of debris avalanche deposit was superficially remobilized when overrun by Neoglacial advance (and subsequent retreat) of Serpent Tongue Glaciers. Terminal positions of glacier snouts are dotted for 1951, entire for 1984-87. Contour interval $200 \mathrm{ft}$; selected elevations are given in feet (1 $\mathrm{m}=3.28 \mathrm{ft}$ ). 


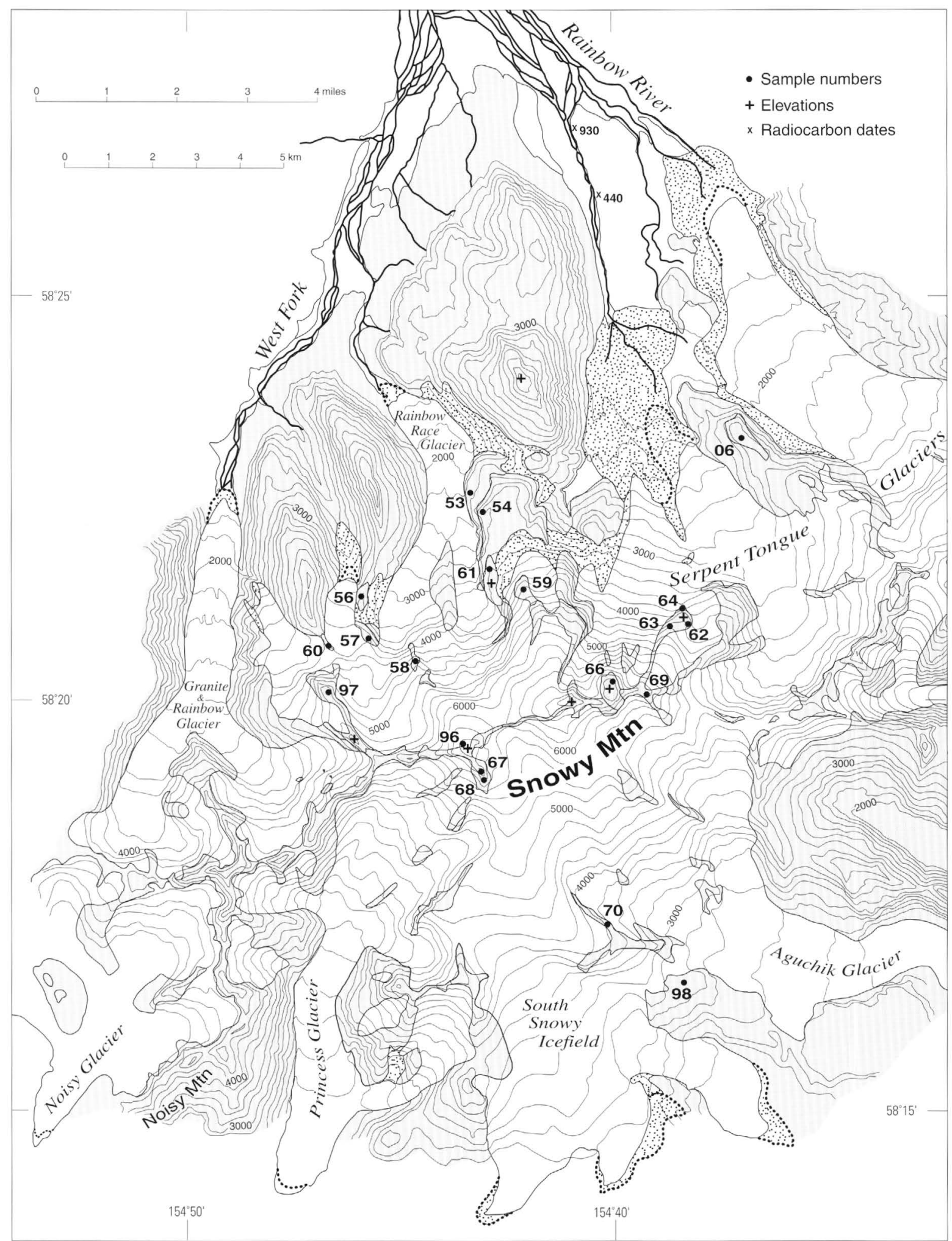

Figure 2B. Place names mentioned in text and locations of samples listed in tables 2 and 3. There being no ambiguity, only the last two digits of the sample numbers given in the tables are shown on the map. Same base as panel $A$. Topography simplified from USGS 1:63,360 quadrangles Mt. Katmai A2, A3, B2, and B3. In northern part of map, sites of two radiocarbondated samples atop Rainbow River debris avalanche are indicated by $\times 440$ and $\times 930$, as discussed in text. 

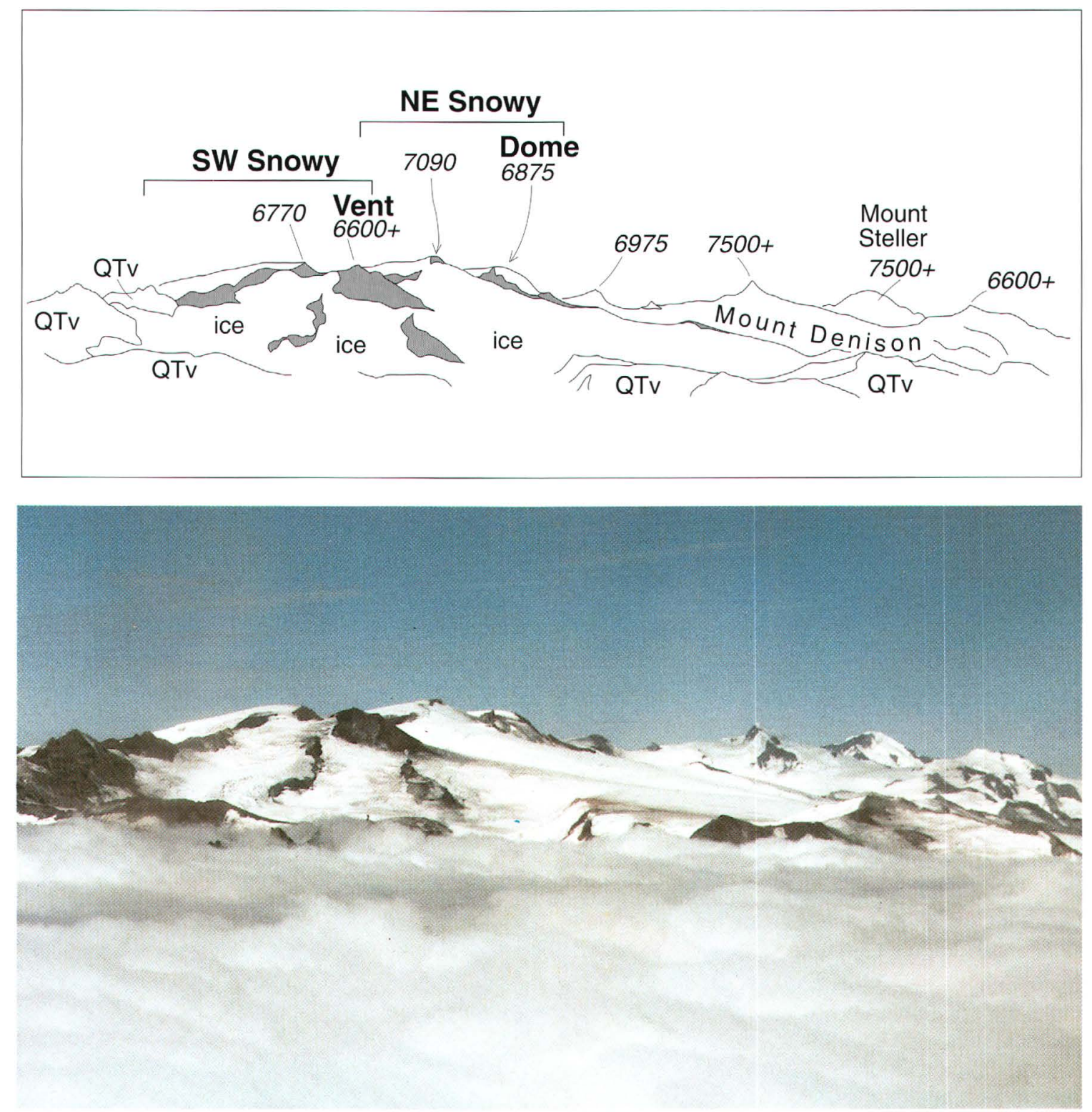

Figure 3. Alaska Peninsula rangecrest, July 1997: A 25-km-long reach of the main divide as seen northeastward from upper Katmai River (fig. 1). Left half of panorama shows the pair of Snowy Mountain volcanoes; right half shows Denison and Steller volcanoes, as indicated in labeled profile. Mount Steller lies $4 \mathrm{~km}$ behind (ENE. of) Mount Denison. Products of the two Snowy Mountain vents are shaded. QTv, volcanic rocks, largely andesitic to dacitic, of several unidentified centers, of late Tertiary and possibly early Quaternary age (Shew and Lanphere, 1992; Riehle and others, 1993). Elevations in feet $(1 \mathrm{~m}=3.28 \mathrm{ft})$.

ft) scoured on an andesite lava flow $\left(60.9\right.$ percent $\left.\mathrm{SiO}_{2}\right)$ that thickens to $100 \mathrm{~m}$ distally (fig. 5). This rests on an even thicker andesitic lava flow that was not sampled (fig. 5).

A few kilometers north of this arête, two ridge-capping andesite remnants, each about $700 \mathrm{~m}$ long, rest directly on Jurassic basement rocks. Each consists of a single lava flow $60-80 \mathrm{~m}$ thick of olivine-bearing pyroxene andesite (59.9, 58.7 percent $\mathrm{SiO}_{2}$ ). Although only $4-5 \mathrm{~km}$ from the vent complex, these lavas are today the most distal products of the Southwest Snowy cone preserved north of the drainage divide.

South of the divide, a parallel pair of kilometer-long cleavers of rubbly andesite trend and dip southwest away from the vent complex, and a large lava tongue, mostly ice covered, extends about $5 \mathrm{~km}$ southeastward (fig. 2). The latter consists of one or possibly two lava flows forming a $150-\mathrm{m}$ high bench at its eroded terminus, the only good exposure. The rim-forming lava of this 4,000-ft bench ( $5 \mathrm{~km}$ southeast of the vent; sample $2570 ; 70$ in fig. $2 B$ ) is olivine-bearing pyroxene andesite (57.9 percent $\mathrm{SiO}_{2}$ ). 

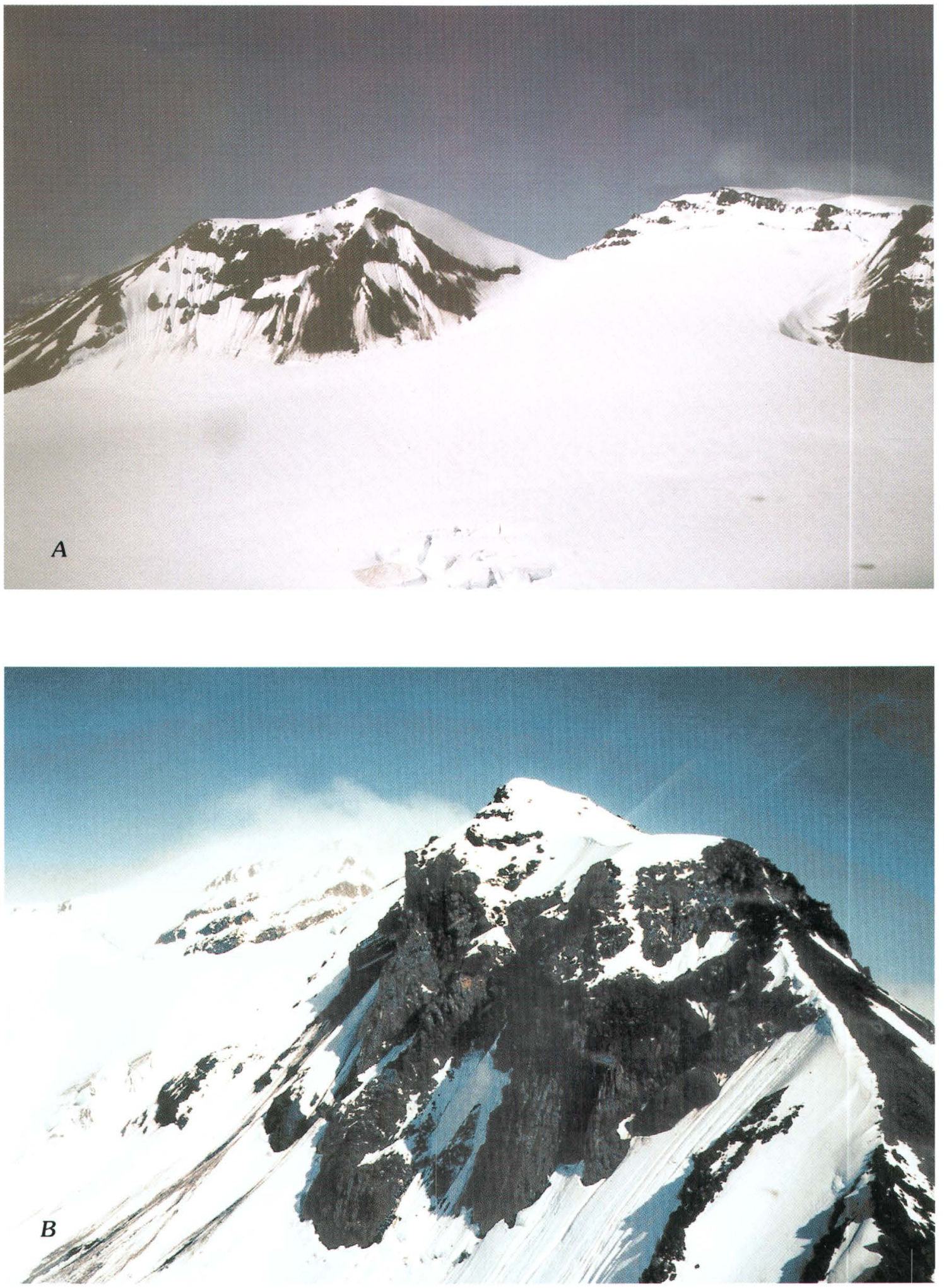

Figure 4. Two views of Southwest Snowy edifice, July 1998. A, East side of intrusive vent complex (swayback knob 6600+) and, at right, north-dipping stack of lava flows that make up Peak 6770. Vertical exposures visible are, respectively, $225 \mathrm{~m}$ and $175 \mathrm{~m}$. View toward WSW. $B$, Southwest face of intrusive complex (knob 6600+), with lava stack of Peak 6770 in background clouds. View toward NNE. Foreground face, about $200 \mathrm{~m}$ high, consists below of steeply jointed intrusive andesite, overlain by rim cliff of chaotic vent breccia, which is densely agglutinated and cut by dikes. These rocks are in turn overlain by remnants of three lava flows, each 10 to $15 \mathrm{~m}$ thick, that cap knob $6600+$. 


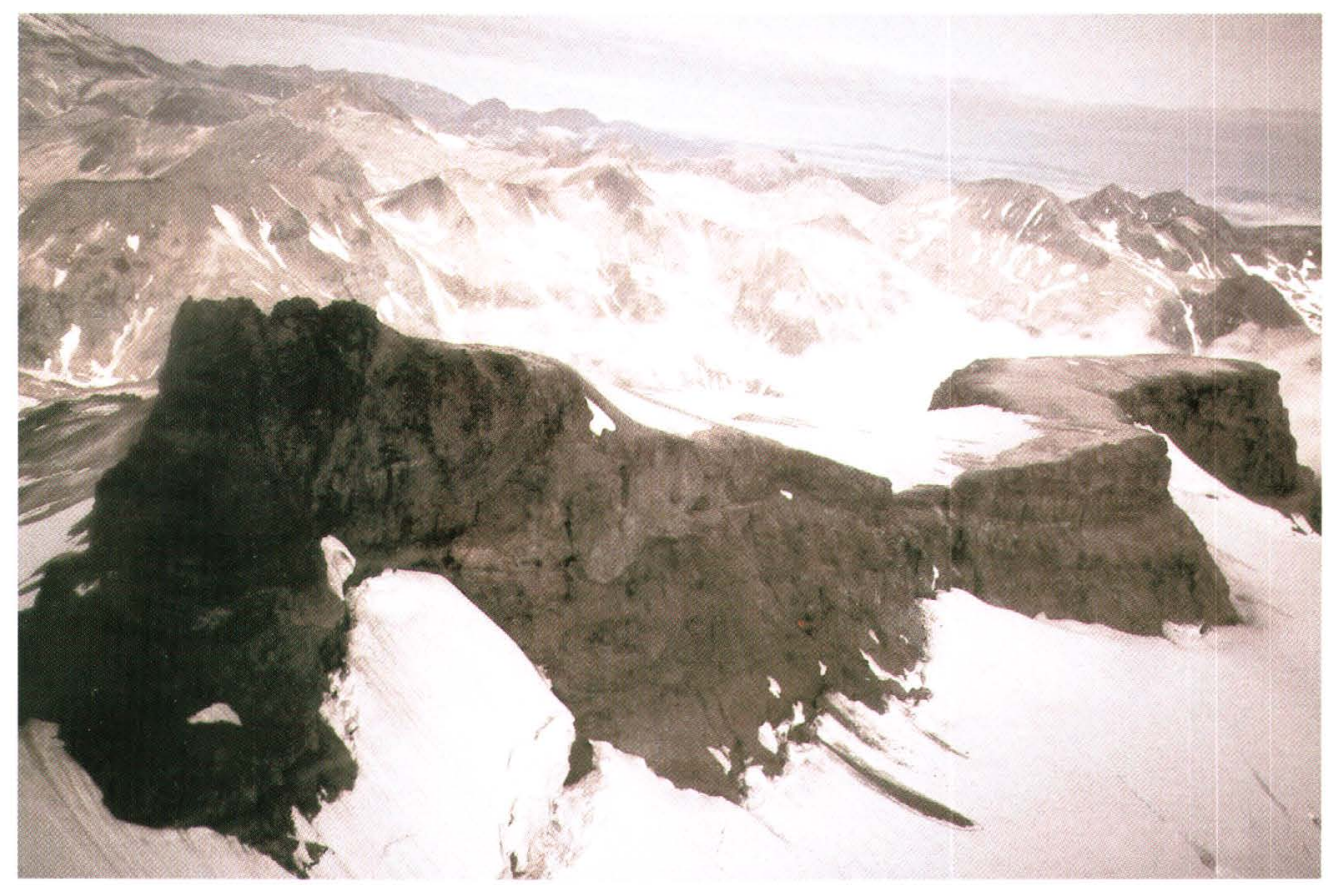

Figure 5. Three andesite lava flows forming the glacially carved, sinuous, WNW. ridge of Southwest Snowy volcano, July 1999. At right, mesa $5300+$ is scoured atop the middle flow, which is only 10-15 m thick at the left but thickens distally to $100 \mathrm{~m}$ at its eroded terminus. Ramping over this flow from the left, the top flow (rich in black glassy zones) maintains a 60 -m-thick remnant that forms Crag 5720 . Base of the lowest flow is ice covered; flow is $60 \mathrm{~m}$ thick in foreground and as thick as $150 \mathrm{~m}$ distally (below the promontory at far right). Its upper part is brecciated and oxidized, and locally (as at the lower left) the flow appears to be compound. View westward to nameless mountains of pre-Quaternary basement rocks on the Ikagluik-Rainbow divide. Pale-gray veneer on mesa (and on many distant slopes) is pumice-fall deposit of 1912 from Novarupta, which lies $23 \mathrm{~km}$ WSW.

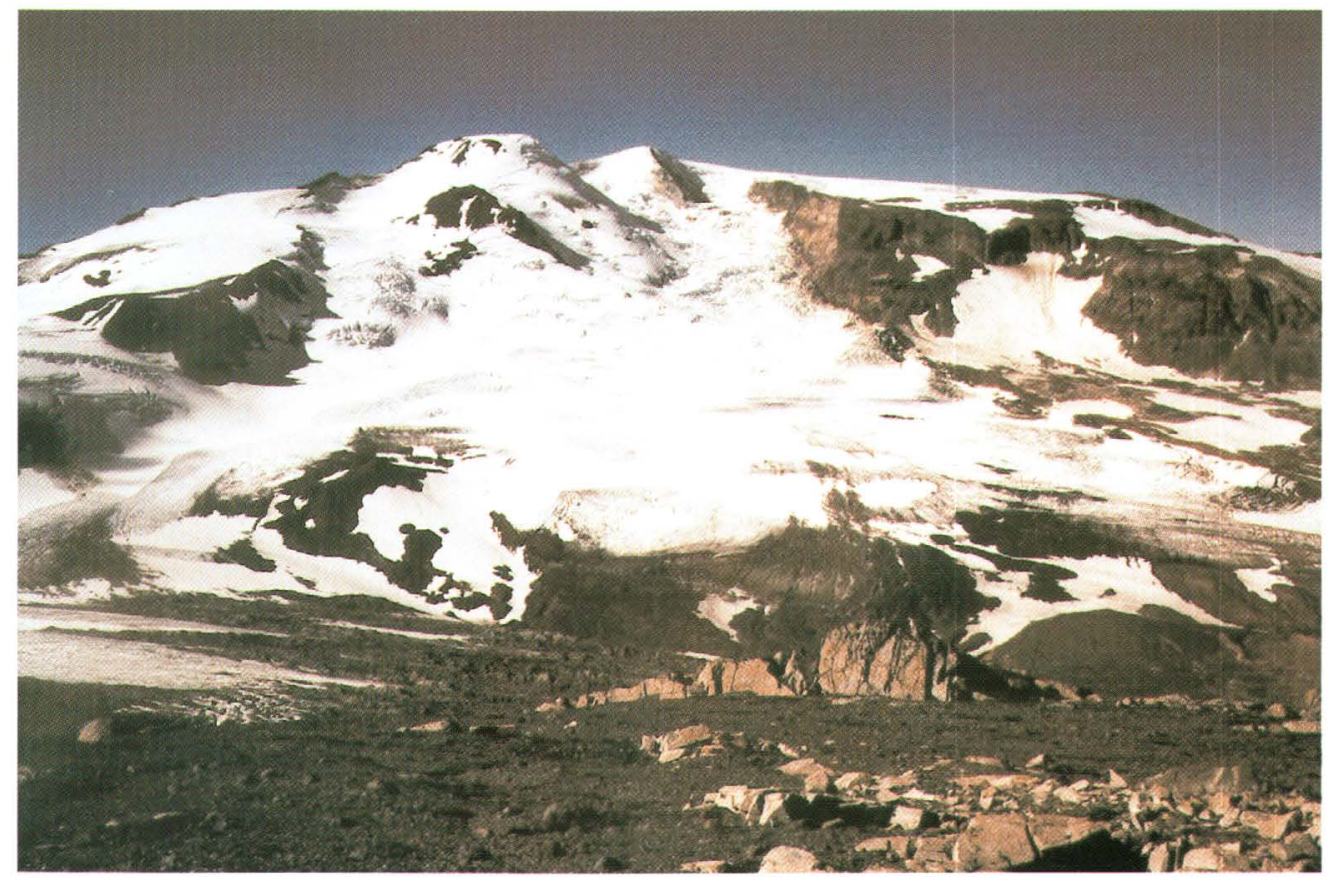

Figure 6. Ice-topped Holocene lava dome (Peak 6875) on central skyline, partly filling ice-mantled amphitheater on northeast slope of Northeast Snowy edifice, July 1999. True summit (Peak 7090) lies just behind dome to its right. Radial dips surrounding amphitheater define Pleistocene edifice. Smooth skyline slope at right is north-dipping planeze that extends northward into staircase stack of thick coulees (just out of frame to right), illustrated in figure 10. Amphitheater originated by sector collapse and subsequent modification by ice of the acid-altered core of the edifice. Exposed walls of the amphitheater are hydrothermally altered orange-brown, yellow, and white, severely so in permeable breccia zones. Intact remnant of outward-dipping edifice lavas (surrounded by snow) lies at northeast foot of the lava dome. View southwestward across Serpent Tongue Glacier from ridge 3075 (sample site K-2606; 06 in fig. 2), 6 km from the dome. 


\section{Northeast Snowy Mountain Edifice}

The northeasterly cone of the contiguous pair is likewise in large part a Pleistocene edifice, but unlike its companion it has erupted at least once during the Holocene. Nearly as iceravaged as the other cone, it nonetheless has almost three times more ice-free surface exposure. Most exposures, however, are along or north of the rangecrest, even though the vent itself lies right on the divide. Because such unilateral asymmetry is unlikely to reflect the eruptive behavior of a free-standing unconstrained cone, it seems required that a large fraction of the edifice have been glacially stripped from the south slope (fig. 2).

\section{Holocene Dome}

The Holocene lava dome was extruded just inside the headwall of a parabolic amphitheater, open to the northeast (fig. 6), probably directly above the long-term conduit of the stratovolcano. Lavas exposed on the amphitheater walls are severely ice eroded and hydrothermally altered, contrasting with the fresh dome lava, which is coarsely blocky, scoriaceous to densely vitrophyric, black to dark gray-brown, and little eroded (despite its 10- to 30-m-thick cap of ice). The dome has more than $500 \mathrm{~m}$ of relief concealed by ice on its north side (fig. 7) and $250 \mathrm{~m}$ of relief well exposed on its southeast side (fig. 8). The southeasterly exposure is a stubby exogenous flow lobe that drapes off the dome and distally overlies hydrothermally altered lavas of the crater headwall (fig. 8), perhaps also penetrating a now-concealed breach in that headwall. A smaller exogenous lobe (fig. 9) hangs off the ice-clad southwest face of the dome, and the ice-covered NNW. nose of the dome (figs. 6,7) might be a third one. A sample from atop the dome is plagioclase-rich pyroxeneandesite vitrophyre, which at 62.8 percent $\mathrm{SiO}_{2}$ is virtually a dacite. Of all the units we sampled at Snowy Mountain (fig. $2 B$ ), only the dome lava contains amphibole, and it has only a trace.

\section{Amphitheater}

The amphitheater containing the dome occupies a $50^{\circ}$ sector high on the cone and widens distally (fig. 6). Such amphitheaters can sometimes be no more than breached summit craters, filled and enlarged by glacial ice, but they also commonly form catastrophically by sector collapse (with or without concurrent eruption), generating debris avalanches and derivative stream-borne debris flows. A hummocky debrisavalanche deposit just beyond the termini of the Serpent

Tongue Glaciers (fig. 2) is derived principally from the Northeast Snowy amphitheater, as indicated by its abundance of hydrothermally altered andesitic debris, which imparts a characteristically pale-orange color to the bulk deposit. The avalanche deposit is present only in the valley directly north of the amphitheater, and the altered core of the volcano now occupied by the amphitheater is the only known source for the orange debris.

Evidence against forming the entire amphitheater by sector collapse, however, is the intact planeze of edifice lavas (surrounded by ice) at the northeastern foot of the dome (figs. 6, 7). This NE.-dipping remnant of the original shell of the cone, located at the northeast edge of the amphitheater, was evidently bypassed by the avalanche, which can thus be inferred to have issued only from the western two-thirds of the amphitheater. The western and southern headwalls of the amphitheater are higher and more pervasively altered than the eastern wall, consistent with the inferred source asymmetry. The sector collapse greatly enlarged what was probably a former crater, and the amphitheater has itself been enlarged by subsequent glacial erosion.

The amphitheater thus circumscribed occupies an apparent collapse area of about $1.5 \mathrm{~km}^{2}$, whereas the avalanche deposit (described more fully in a later section) originally covered an area of at least $22 \mathrm{~km}^{2}$ and ranged from 5 to $50 \mathrm{~m}$ in thickness. If the average thickness of the whole deposit were in the range 10-20 $\mathrm{m}$, then its (pre-erosional) volume would have been between 0.2 and $0.45 \mathrm{~km}^{3}$. Derivation of such a volume entirely from the $1.5-\mathrm{km}^{2}$ amphitheater therefore requires that the average original thickness of the mass displaced need only have been $150-300 \mathrm{~m}$. As the present-day relief on the south and west walls of the amphitheater is $100-300 \mathrm{~m}$ (plus an unknown thickness of ice infilling its floor), the volumetric match is satisfactory despite the uncertainties.

Prior to extrusion of the Holocene dome, the previous summit vent (probably an ice-filled crater) had been the focus for long-term hydrothermal weakening of the upper part of the cone. The crater and much of its altered envelope slid away northward, plausibly destabilized by intrusion of magma that subsequently produced the lava dome, leaving behind an amphitheater much larger than any original crater. After extrusion of the dome inside the amphitheater, accumulation of ice produced three discrete glacial tongues, one descending along each side of the dome, a third separating the dome from the isolated remnant planeze, and all three merging downslope into the main glacier (figs. 6, 7).

\section{Cone-Forming Lavas}

The stacks of lava flows exposed in several ice-free segments around the rim of the amphitheater all dip radially away at $20^{\circ}-45^{\circ}$ (figs. 2, 6-9). Some of the steepest dips, adjacent to the dome, may have been increased slightly by tilting during dome extrusion. Steeply dipping ultraproximal lavas are dominated by flow-breccia zones (figs. 8, 9); the accompanying massive interior zones are generally only 5-10 $\mathrm{m}$ thick proximally but thicken downslope as dips diminish. Such breccia zones provide the main avenues of permeability for acid fluids to spread away from the conduit and crater, 


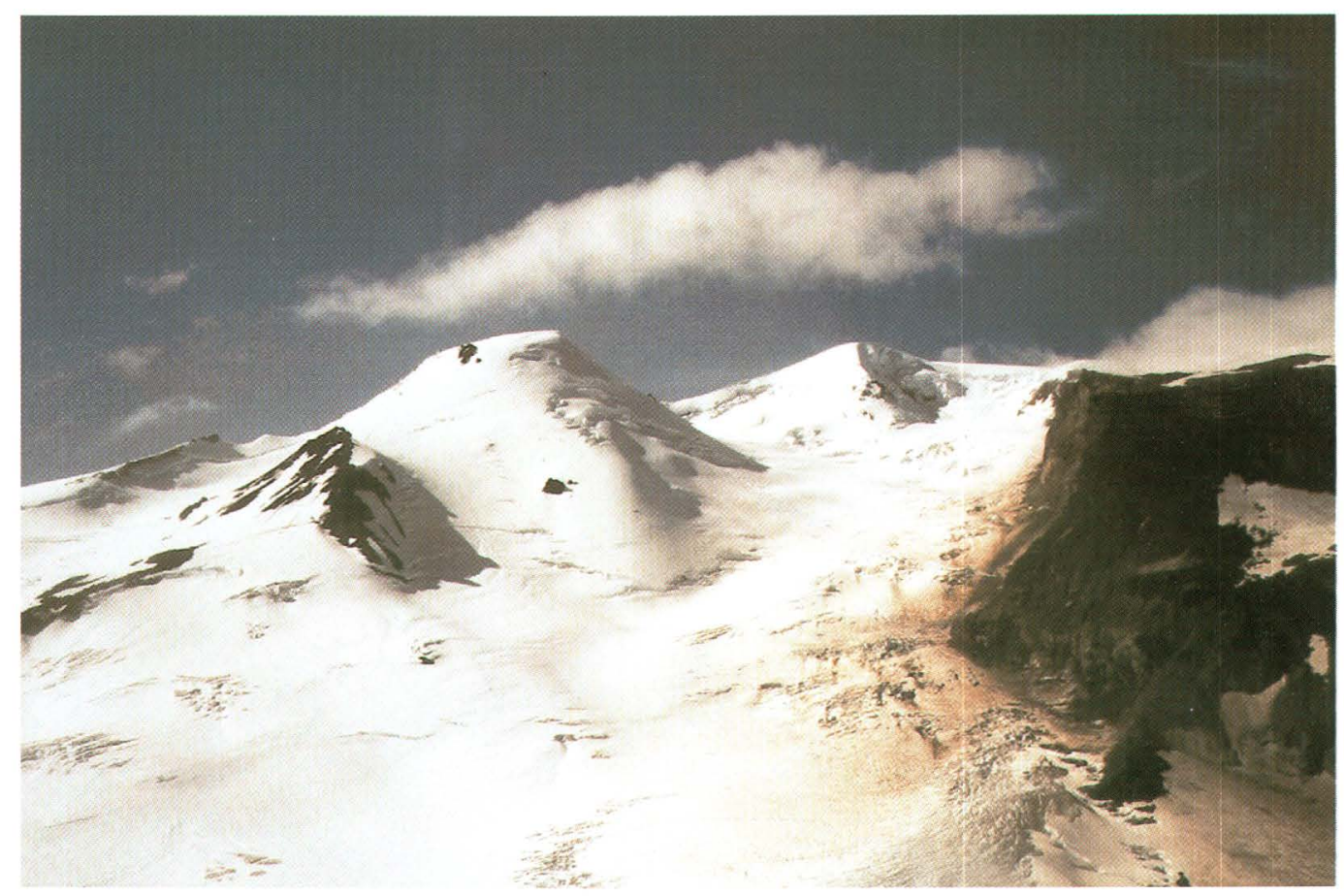

Figure 7. Southeastward view of Holocene lava dome (Peak 6875) extruded at head of amphitheater seen in figure 6. Icy summit on right skyline is Peak 7090, part of the headwall. Its lavas, like those of the two prows at the left and the 300-m cliff at the right, dip radially away from the dome, serving to define the gutted center of the Northeast Snowy edifice. Relief on the ice-covered north face of the dome exceeds $500 \mathrm{~m}$. Reddish-brown discoloration of glacier surface at right is caused by rockfall and windblown sand and silt from disintegrating cliff of hydrothermally altered andesite at right. Upper part of Serpent Tongue Glacier in foreground. Photo July 1998.

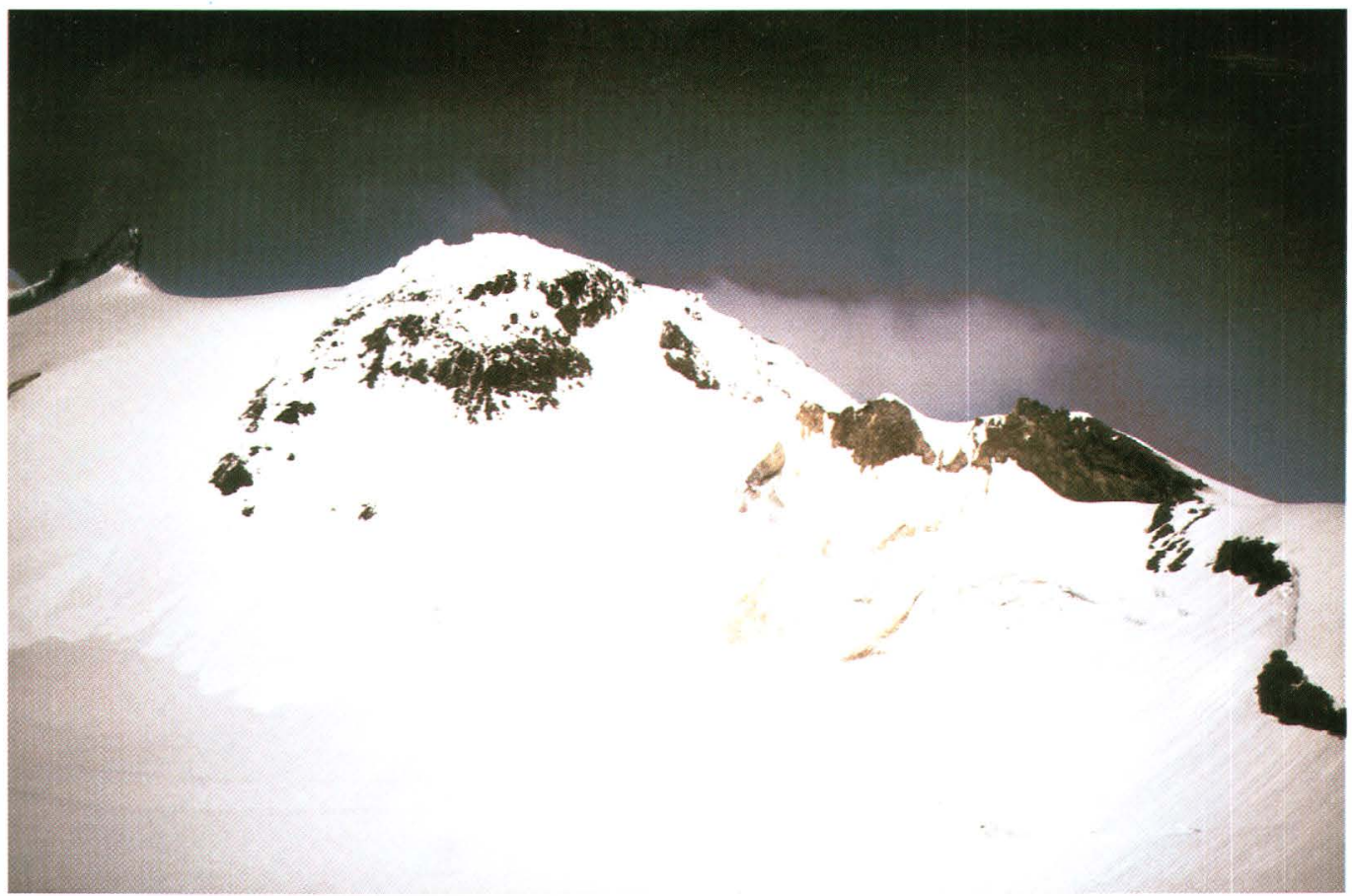

Figure 8. Steep exogenous lava lobe that drapes 250-m-high southeast face of Holocene lava dome (Peak 6875) occupying gutted core of Northeast Snowy edifice, July 1998. Best exposures of ice-mantled but little-eroded blocky lava dome are here on its southeast side. Remnants of stacked lava flows that built the ice-ravaged Pleistocene edifice dip $25^{\circ} \mathrm{E}$. at right, $45^{\circ} \mathrm{WSW}$. on crag at upper left. Within the lava stacks, permeable breccia zones are hydrothermally altered rusty orange- and yellow-brown; massive zones (flow interiors) are fresh and dark gray. View northwestward. 


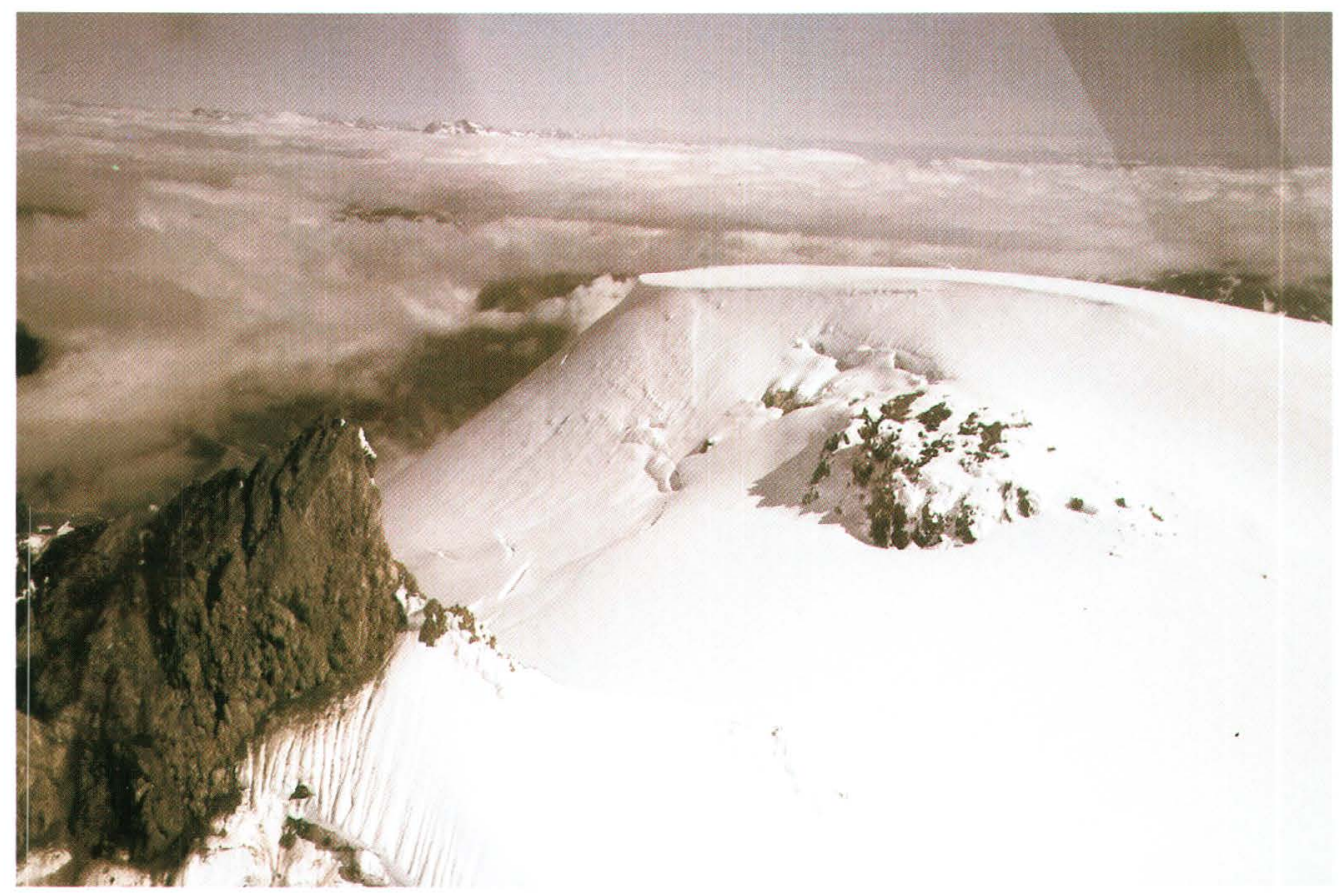

Figure 9. View northeastward past Crag 6700+ to southwest face of Holocene dome (Peak 6875), which exposes a 25-m-thick stubby lobe of fresh, little-eroded, blocky andesite. Crag at left lies on south rim of cirque-amphitheater and midway between the dome and Peak 7090 (fig. 2); it consists of coarse lava-flow breccia that dips as steeply as $45^{\circ}$ WSW., away from the dome. Smoothed and corniced snow surface atop dome is a transient eolian feature that conceals a capping of crevassed ice as thick as $30 \mathrm{~m}$. Foreground snow saddle is about $100 \mathrm{~m}$ below top of dome and about $70 \mathrm{~m}$ below top of Crag 6700+. Photo July 1998.

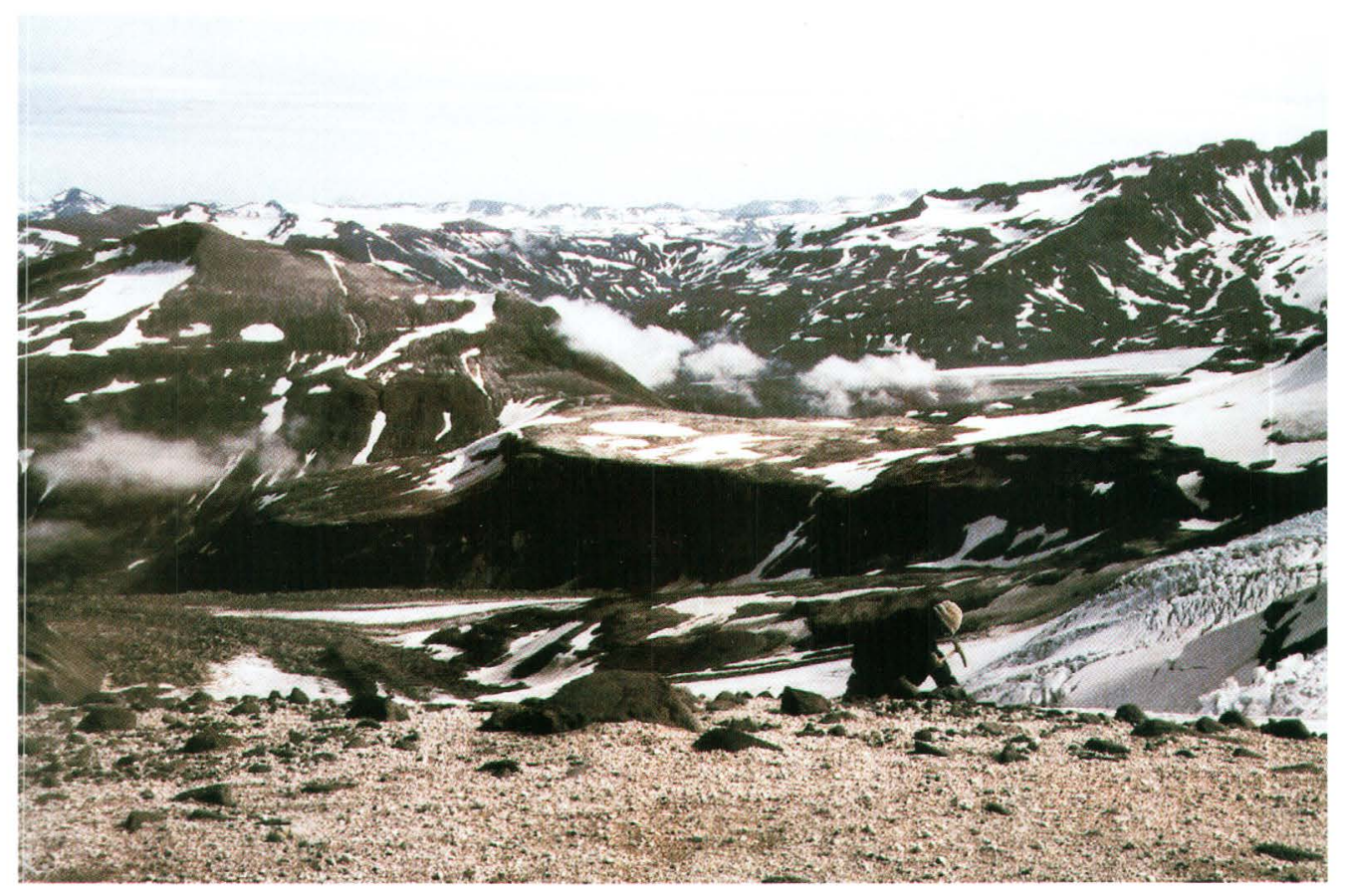

Figure 10. Glacially scoured staircase of andesite-dacite lava flows that descends northward from Northeast Snowy volcano and divides the forks of Rainbow River, July 1999. Lowest and second benches are compositionally identical dacite lavas, each $150 \mathrm{~m}$ thick. Small mesa right of center (Bench 3685) is a third (andesitic) lava flow 30-50 m thick, apparently banked in against the stack of thicker flows and probably derived from the other (southwest) cone. Still higher bluff (above snow slope at the right margin) is another dacite flow about $200 \mathrm{~m}$ thick. Forming the broadest bench, the second flow of the stack yields a K-Ar age of $171 \pm 8 \mathrm{ka}$ (table 1). At left in middle distance, smooth-sloping Peak 4665 consists of pre-Quaternary basement rocks, as do most of the skyline peaks and ridges. View is northeastward across head of Rainbow Race Glacier from sample site K-2597 (97 in fig. 2) on WNW. ridge of Southwest Snowy edifice. 
promoting hydrothermal alteration within the cone's outwarddipping lava stacks for as much as $2 \mathrm{~km}$ radially (e.g., fig. $6)$.

Three samples from two of the NE.-dipping flows in the stack that extends from the cirque rim $2.5 \mathrm{~km}$ northeastward to bench 4340 (figs. 2, 6) are mutually similar pyroxene andesites (61.7-61.8 percent $\mathrm{SiO}_{2}$ ). The top flow on the east shoulder of the amphitheater (fig. 8) is plagioclase-rich pyroxene dacite (63.7 percent $\mathrm{SiO}_{2}$ ), slightly more evolved than the adjacent Holocene lava dome.

Most of the surviving volume of the Northeast Snowy cone forms a great staircase of thick lava flows that descends 6 $\mathrm{km}$ northward from Peak 7090 (figs. 2, 6, 10). Proximal exposure is limited by ice cover, so only a single, vertically jointed lava flow, $100 \mathrm{~m}$ thick, crops out along the amphitheater's west wall above the $6,000-\mathrm{ft}$ level. Farther down that sidewall, just below the strongly altered zone shown in figure $6, \mathrm{~N}$.-dipping stacks of at least six lava flows are exposed on cliffs below lava benches at 5,400 ft and 4,600 ft (fig. 6). As much as half the material in these 300 -m cliff sections along the western Serpent Tongue Glacier is flow breccia, many zones of which have been selectively discolored yellow- or orange-brown by hydrothermal fluids that visibly affected them for as far as $3 \mathrm{~km}$ north of the vent-plugging dome. A few kilometers northwest, the (unaltered) west side of this same stack of flows is well exposed as a series of cliff-bounded lava benches that extends to an elevation as low as $2,000 \mathrm{ft}$ along the eastern wall of Rainbow Race Glacier (fig. 10). Three of these bench-forming distal lava flows, each 150-200 m thick, are pyroxene dacite (63.1-63.6 percent $\mathrm{SiO}_{2}$ ) and are among the most evolved products identified at Snowy Mountain. An accompanying flow only $30-50 \mathrm{~m}$ thick (figs. 2,10 ) is olivinebearing pyroxene andesite $\left(57.7\right.$ percent $\left.\mathrm{SiO}_{2}\right)$ that banked against the stack of dacites and probably erupted from the Southwest Snowy vent, $4 \mathrm{~km}$ south.

The great thickness of these lava flows at their eroded termini, which are today just upstream of a granite-walled glacial gorge (fig. 2), suggests that some or all of them could originally have extended many kilometers farther down Rainbow River.

\section{Fumaroles}

No fumaroles have been observed on Southwest Snowy, but two separate areas on Northeast Snowy were reported to have been steaming in the summer of 1982 (Motyka and others, 1993). They recorded diffuse steam emissions issuing at $89^{\circ} \mathrm{C}$ from holes melted in the ice capping Peak 7090 , and they mentioned steaming ground on the dome, Peak 6875. On helicopter flights in late July of both 1998 and 1999, we looked closely at Peak 7090 , hovered all the way around Peak 6875, and landed atop the latter without seeing any emissions or detecting any fumarolic odors. Either the emissions have diminished, or we overlooked them, or thickening icecaps have suppressed them. The ice capping the dome in 1998-1999 (figs. 6-9) was many times more voluminous than that visible in aerial photographs taken in July 1951 (such details are obscure in the 1984 aerial photographs in our possession), so the third possibility seems not unreasonable.

\section{Debris Avalanche and Debris Flows}

\section{Rainbow River Debris-Avalanche Deposit}

A hummocky debris-avalanche deposit is well preserved between the eastern forks of Rainbow River (fig. 2) as far as $14 \mathrm{~km}$ north of the amphitheater headwall at Peak 7090. Though extensively overgrown with scrub alder, exposures of the deposit are abundant and are generally pale orangebrown, reflecting derivation principally from the hydrothermally altered core of the edifice. The present-day headwall and western sidewall of the amphitheater consist of altered andesite of similar color (fig. 6). Block-rich hummocks, many of them 100-400 $\mathrm{m}$ across, stand as high as $30 \mathrm{~m}$ above adjacent depressions on the deposit surface. Relief adjacent to glacier-fed stream gorges incising the medial part of the deposit reaches $40 \mathrm{~m}$ and locally may even exceed $50 \mathrm{~m}$. The avalanche sheet generally thins northward, but even distal remnants have hummocks and ridges $20-30 \mathrm{~m}$ high. The moving avalanche was generally valley confined, not climbing the sidewalls appreciably, though it did apparently overrun three bedrock ridges in its path (fig. $2 A$ ) that stand $100 \mathrm{~m}$ or more above the surface of the deposit.

The main glacier-fed streams have cut channels right through the deposit and a few lesser streams head in the deposit itself. Much of the sheet, however, still lacks integrated drainage and remains marked by numerous depressions (20-400 m wide), many of which are pond filled and lack surface outlets. An unknown fraction of the distal part of the sheet has been removed, principally having been reworked as alluvium on the braided outwash plain of Rainbow River (fig. 2). Proximally, any avalanche debris that may have been deposited supraglacially has since been swept away by glacial transport. Medially, the deposit was overrun by Little Ice Age (A.D. 1400-1900) advance of three lobes of the Serpent Tongue Glaciers (fig. 2). Recession of those ice tongues during the last century or so has exposed overrun swaths of the avalanche deposit extending $1.5-2.5 \mathrm{~km}$ beyond present glacier termini that were superficially remobilized as till (fig. 2). Below the modern glacier termini, about $10 \mathrm{~km}^{2}$ of the deposit are little modified, $7 \mathrm{~km}^{2}$ have been overrun and re-exposed by glacier fluctuations, and at least $5 \mathrm{~km}^{2}$ have been reworked as alluvium. The original area of the deposit was thus no less than $22 \mathrm{~km}^{2}$, not including distal runout facies or the proximal devastated area (about $7 \mathrm{~km}^{2}$ ) now swept clean by younger ice.

Though it obviously postdates withdrawal of the regionally extensive late Pleistocene alpine valley glaciers (Riehle 
and Detterman, 1993), the emplacement age of the avalanche is poorly known. Because the deposit was overrun by the Little Ice Age advance of the Serpent Tongue Glaciers, it is likely to be older than 500 years. Poorly integrated surface drainage, meager soil development, and immature vegetation on the deposit, as well as scant erosion of the lava dome emplaced in its source amphitheater, are features that suggest a late Holocene age for the collapse.

The wind-scoured surface of the avalanche is generally barren or is directly overlain by remnants of the Novarupta ash fall of 1912. Distally, however, where the surface is protected by alders and willows, a few centimeters of eolian silt (incipiently transforming into soil) had accumulated atop the avalanche prior to deposition of the 1912 ash. At two distal bluff-rim sites (fig. $2 B$ ), we obtained radiocarbon ages from the base of such an organics-bearing silt. At the southerly site (fig. $2 B$ ), the basal $3-4 \mathrm{~cm}$ of incipient soil developed on the reworked top of the avalanche deposit yielded an AMS age of $440 \pm 40{ }^{14} \mathrm{C}$ yr B.P., which calibrates to a calendar age in the interval 1433-1471 A.D. At the northerly site, the basal $4 \mathrm{~cm}$ of a 10- to 13-cm accumulation of silty soil (resting directly on the primary avalanche deposit) yielded a conventional age of $930 \pm 120{ }^{14} \mathrm{C}$ yr B.P., which calibrates to a calendar age in the interval 997-1240 A.D. About $500 \mathrm{~m}$ downstream from the latter site, the avalanche deposit banks against a postglacial landslide deposit of local derivation and nonvolcanic composition. Atop this slide mass, the accumulation of Holocene eolian silt is as thick as $80 \mathrm{~cm}$, at least six times greater than the maximum thickness found atop the adjacent debris avalanche. We conclude that the Rainbow River debris avalanche broke loose from Snowy Mountain in the late Holocene, roughly 1,000-1,500 years ago.

\section{Debris Flows}

The glaciers of Snowy Mountain drain directly into no fewer than nine separate river valleys (fig. 1) - three forks of Rainbow River, two tributaries of Katmai River, the canyon of Soluka Creek, an unnamed gorge that runs to Hidden Harbor, and two canyons that drain to Kukak Bay. Just 4-12 km east of the volcano, three additional glacier-fed canyons run down to Kukak Bay, and a fourth drains to Rainbow River (fig. 1). All 13 drainages are susceptible to the flooding or debris-flow inundation that might be initiated by eruption or avalanching of the edifice or by fallout of proximal tephra on the ice. As the area is uninhabited, the main debris-flow hazard is to fish and wildlife resources.

We reconnoitered all the drainages just mentioned by means of low-altitude helicopter flights, searching for debrisflow deposits that might have originated at Snowy Mountain. The outwash-laden braided streams occupying these canyons have vigorously reworked such material into alluvium, leaving very few cutbanks in Holocene mass-flow deposits. Scattered remnants of 1912 or younger pumiceous debris flows and hyperconcentrated (phenocryst-dominated) sandflows reworked from the regional Novarupta fallout blanket of 1912 are present, but mass-flow deposits potentially attributable to Snowy Mountain are rare. In particular, primary runout deposits from the Holocene debris avalanche were sought but not identified downstream on the Rainbow and Savonoski Rivers (fig.1).

Debris-flow deposits several meters thick do form steep cutbanks at two isolated sites $23 \mathrm{~km}$ and $27 \mathrm{~km}$ north of Snowy Mountain's summit (fig. 1). Recognized from the air, neither site was visited owing to difficulty of access, so their age and provenance remain unknown. A third mass-flow deposit $11 \mathrm{~km}$ north of the summit banks against the debrisavalanche deposit on a local right-bank terrace of Rainbow River at an elevation of $950 \mathrm{ft}$ (figs. 1, 2). The massive orange-brown sandy deposit is $2-3 \mathrm{~m}$ thick, has a median grain size diameter of only $2.1 \mathrm{~mm}$, and contains only 10 weight percent clasts larger than $8 \mathrm{~mm}$ and merely one percent silt and clay (particles smaller than $0.063 \mathrm{~mm}$ ). Identifiable clasts are mostly phenocryst-rich andesites, about a third of them hydrothermally altered, along with fewer than 5 percent nonvolcanic basement rocks. Although the material certainly came originally from Snowy Mountain, the sandy deposit itself probably resulted from stream flow that transported material remobilized from the avalanche and flushed it of fine-grained constituents.

\section{Behavior of Glaciers}

The icefields blanketing Snowy Mountain distribute outward into 10 valley glaciers (fig. 2), altogether representing about $155 \mathrm{~km}^{2}$ of present-day ice. On Mount Mageik, another ice-clad volcano, similar in elevation to Snowy Mountain and only $35 \mathrm{~km}$ southwest along the rangecrest, we found the ice volume to have been shrinking substantially and the termini of all glaciers to have receded during the interval of 20th-century observation (Hildreth and others, 2000). Comparison of aerial photographs of Snowy Mountain taken in 1951 and 1983-84, however, reveals no similarly consistent pattern. (The following notes refer to behavior of glacier termini only during the 33-year interval 1951-1984. We know of no pre-1951 photographic record for Snowy Mountain, and our own 1998-99 observations yielded no quantifiable changes of terminal positions from those of 1984.)

To the northeast, the three lobes of the Serpent Tongue Glaciers behaved independently between 1951 and 1984. The terminus of the southwest lobe did not change position, that of the central lobe retreated $1,200 \mathrm{~m}$, and that of the larger northeast lobe (which originates on Mount Denison) retreated $400 \mathrm{~m}$. Prior to 1951 , the three lobes had retreated 1.5 to 2.5 $\mathrm{km}$ from their Neoglacial (probably Little Ice Age) maxima (fig. 2).

To the southeast of Snowy Mountain, the terminus of Aguchik Glacier (fig. 2), which fronts on a great outwash plain at the head of Kukak Bay, retreated 1,000 m between 1951 and 1984. To the south, the extensive South Snowy Icefield (fig. 
2) trifurcates distally into three modest ice tongues (fig. 2).

The southwestern and central tongues each retreated only 200 $\mathrm{m}$ from 1951 to 1984 , while the longer southeastern tongue retreated more than $600 \mathrm{~m}$. In contrast, only 4-5 km farther west, Princess Glacier (so named by Griggs, 1922, p. 131-132) has actually advanced $150 \mathrm{~m}$ since 1951 (fig. 2). A few kilometers still farther west, the East Katmai Icefield (fig. 2) contributes both to Noisy Mountain Glacier, which likewise advanced $150 \mathrm{~m}$ since 1951, and to north-flowing Ikagluik Glacier (just west of fig. 2), the terminus of which is unchanged since 1951.

Four glaciers on the northwest side of Snowy Mountain occupy canyons that converge into the west fork of Rainbow River (fig. 2). The westernmost and largest of the four (Granite \& Rainbow Glacier, confined in a granite-walled gorge) retreated $200 \mathrm{~m}$ between 1951 and 1984. The easternmost (Rainbow Race Glacier, likewise a large intracanyon ice tongue with a churning millrace of an outlet stream) retreated about $500 \mathrm{~m}$, although the exact position of its terminus is rendered ambiguous by extensive ice-cored moraine. As for the two lesser glaciers between these (fig. 2), the western terminus has remained virtually stationary, while the eastern has retreated $250 \mathrm{~m}$ since 1951 and at least $1,500 \mathrm{~m}$ from its Little Ice Age maximum (fig. 2). Only for this small glacier and for the three Serpent Tongue Glaciers is good evidence preserved for terminal positions of the Little Ice Age advances. Most of the other glaciers in the district terminate on valley floors filled with braided outwash gravels where vigorous fluvial reworking has removed any Neoglacial moraines.

The marked inconsistency of 20th-century glacier behavior in the Snowy Mountain area may in part reflect distribution of the 1912 Novarupta ash cover, superimposed on the climatically controlled, generally negative, regional ice budget. The blanket of crystal- and pumice-rich fallout of 6-9 June 1912 had a cumulative thickness of 1-2 m on Snowy Mountain. As the principal dispersal sector from Novarupta was toward the ESE. (Fierstein and Hildreth, 1992), the primary fall deposit thinned northward and eastward, respectively, to about $50 \mathrm{~cm}$ around both upper Rainbow River and Kukak Bay (fig. 1). Southwest of Snowy Mountain, however, the deposit thickened to more than 3 $m$ at Katmai River and on Mount Katmai (fig. 1). During the 9 decades since the great eruption, glacier flowage and surface erosion have stripped most of the 1912 ash from the glaciers northeast, east, and southeast of Snowy Mountain, but glaciers to the west and southwest retain thick fallout blankets, especially on their distal reaches. Of the 14 glaciers just mentioned, the ash-covered ones to the west have generally advanced or stagnated historically, whereas the ashfree glaciers farthest east have all receded. The buff pumice mantle apparently retards glacial ablation.

Exhibiting comparable behavior still closer to Novarupta, where the 1912 pyroclastic blanket is several meters thick, the termini of three of the five Knife Creek Glaciers advanced about $100 \mathrm{~m}$ between 1951 and 1987, actually edging out over the adjacent 1912 ash-flow sheet at the head of the Valley of
Ten Thousand Smokes (Hildreth and others, 2000). Positions of the other two termini did not change. The heavily ashcovered advancing glaciers did so despite the fact that two of them had been partially decapitated by the 1912 collapse of Katmai caldera. In contrast, the largely ash-free glaciers of Mount Mageik, which lies just upwind of the principal 1912 fallout sector, have all retreated since 1912 (Hildreth and others, 2000).

Despite the advances of several ash-insulated ice tongues, the ice budget for most glaciers in the region has clearly been negative during the last century or so. As little as 8000 years ago, moreover, these glaciers were far thicker and, coalescing with numerous others, extended many tens of kilometers beyond their recent termini (Riehle and Detterman, 1993). Holocene shrinkage of the glacial cover on steep parts of an edifice like Snowy Mountain elevates the likelihood of failure of oversteepened glacial deposits, cliffy stacks of rubbly lava flows, and hydrothermally altered parts of the volcano. By lifting the deformable ice envelope sealing such unstable materials, the retreat of glaciers can actually increase the hazards of debris avalanches and derivative downstream debris flows.

\section{Geochronology}

Northeast Snowy volcano erupted at least once during the Holocene, as shown by its "postglacial" vent-plugging lava dome, but most of the edifice is severely eroded glacially. To determine how long the volcano has been active, we sought to date some of its oldest lava flows by the K-Ar method. Because the northward-descending staircase of lava flows (figs. 2, 10), which extends from the present summit all the way down to an elevation of 2,000 ft, represents the largest surviving fraction of the edifice, it seemed likely that the basal flow of the stack could be one of the earliest products of the volcano. Our sample of that (dacitic) flow was partly glassy so instead we dated a fully devitrified sample from the compositionally identical overlying flow (K-2554; 54 in fig. 2), determining a high-precision age of $171 \pm 8 \mathrm{ka}$ (table 1).

Sample selection criteria and analytical methods were identical to those described by Hildreth and Lanphere (1994). Because we were seeking high-precision age determinations for late Pleistocene rocks, we employed the multiple-collector mass spectrometer (Stacey and others, 1981) at the U.S. Geological Survey in Menlo Park.

In contrast to Northeast Snowy, there is no evidence that the Southwest Snowy volcano has erupted in the Holocene, as all its products are severely eroded (figs. 4,5 ). The paired edifices occupy adjacent but virtually exclusive areas, so stratigraphic evidence of relative ages by overlap or interfingering is generally lacking. At their mutual saddle, which is largely ice covered (fig. 2), their lava flows appear to abut directly, and exposure is inadequate to discern a relative age. Along the narrow strips of exposure adjacent to the saddle (fig. 2), 
the lava flows from Northeast Snowy are notably more altered hydrothermally. At a single location (Bench 3685; fig. 2), $4 \mathrm{~km}$ north of the summit of Southwest Snowy, a lone lava flow apparently derived from that edifice banked against the previously eroded staircase of flows from the other (northeast) edifice (fig. 10). That flow (sample K-2561; tables 2, 3) is olivine bearing, more mafic ( 57.7 percent $\mathrm{SiO}_{2}$ ), and much thinner than the stack of thick dacite lavas against which it banks. This relationship, if correctly interpreted, provides the only direct stratigraphic evidence for temporal overlap of the active lifetimes of the adjacent ice-mantled edifices.

This stratigraphic inference is supported by a K-Ar age of $92 \pm 10 \mathrm{ka}$ (table 1) for the major southeast-trending lava lobe erupted from Southwest Snowy (fig. 2). This flow (sample $\mathrm{K}-2570$; tables $1-3$ ) is compositionally similar to the northerly flow just discussed (K-2561; 61 in fig. 2), and it may be the basal Quaternary lava flow on the south side of the edifice. Where its ice-mantled snout crops out on a bench at 4,000 ft, exposure during our visits was inadequate to discern whether the flow rests directly on the Tertiary andesites exposed downslope or whether another lava flow from Southwest Snowy separates them.

On the north side of Southwest Snowy, a basal lava flow that rests on Jurassic basement $3.3 \mathrm{~km}$ northwest of the summit yielded an age of $199 \pm 9 \mathrm{ka}$ (table 1). Somewhat surprisingly, the uppermost lava flow of the summit-forming stack atop Peak 6770 gave an (analytically indistinguishable) age of $196 \pm 8 \mathrm{ka}$ (table 1). As these lava flows bracket most others preserved on Southwest Snowy, it seems apparent that much of the small cone grew very rapidly. More than 100 k.y. of glacial erosion ensued, however, scouring away much of the southern flank of the volcano before the big southeast-trending lava lobe was emplaced at $92 \pm 10 \mathrm{ka}$. No younger units are recognized at Southwest Snowy.

In summary, it is inferred from present data that eruptive activity began by $200 \mathrm{ka}$ at Southwest Snowy and by $170 \mathrm{ka}$ at Northeast Snowy. Lava-producing eruptions have been few and widely spaced at both cones. The latest activity recognized at Southwest Snowy took place about $92 \mathrm{ka}$, whereas Northeast Snowy has been active as recently as the late Holocene.

\section{Composition of Eruptive Products}

All samples taken from Snowy Mountain are andesites and dacites, the great majority being plagioclase-rich twopyroxene andesites (table 2). Most rocks have 20-40 percent plagioclase phenocrysts as large as $3 \mathrm{~mm}$, about 10 percent pyroxene phenocrysts (orthopyroxene and clinopyroxene in varied but subequal proportions), and 1-3 percent opaque oxide microphenocrysts - largely titanomagnetite. A few lava flows also contain small amounts of olivine, and some of the more mafic products of the Southwest Snowy cone have

Table 1. Whole-rock potassium-argon ages and analytical data.

[Analysts: Potassium by D.F. Siems: Argon by F.S. McFarland and J.Y. Saburomaru. Constants: $\lambda=$ $\left.0.581 \times 10^{-10} \mathrm{y}^{-1}: \lambda_{\beta}=4.962 \times 10^{-10} \mathrm{y}^{-1} ;{ }^{40} \mathrm{~K} / \mathrm{K}=1.167 \times 10^{-4} \mathrm{~mol} / \mathrm{mol}\right]$

\begin{tabular}{|c|c|c|c|c|c|c|}
\hline \multirow{2}{*}{$\begin{array}{l}\text { Sample } \\
\text { number }\end{array}$} & \multirow{2}{*}{$\begin{array}{l}\text { Location } \\
\text { (see fig. 2) }\end{array}$} & \multicolumn{2}{|c|}{ Weight percent } & \multicolumn{2}{|c|}{ Radiogenic ${ }^{40} \mathrm{Ar}$} & \multirow{2}{*}{$\begin{array}{c}\text { Calculated } \\
\text { age }\end{array}$} \\
\hline & & $\mathrm{SiO}_{2}$ & $\mathrm{~K}_{2} \mathrm{O}$ & $\left(10^{-13} \mathrm{~mol} / \mathrm{g}\right)$ & (percent) & \\
\hline K-2554 & $\begin{array}{l}\text { NE Snowy volcano. } \\
\text { Second flow of stack } \\
\text { to north: } 3000 \text {-ft rim } \\
\text { facing Rainbow Race } \\
\text { Glacier; } 4.9 \mathrm{~km} \text { NNW. } \\
\text { of Peak } 7090 \text {. }\end{array}$ & 63.6 & $2.083 \pm 0.008$ & 5.132 & 10.5 & $171 \pm 8 \mathrm{ka}$ \\
\hline $\mathrm{K}-2557$ & $\begin{array}{l}\text { SW Snowy volcano. } \\
\text { Basal lava flow on } \\
\text { basement at } 4000-\mathrm{ft} \\
\text { point, } 3.3 \mathrm{~km} \mathrm{NNW.} \\
\text { of Peak } 6770 .\end{array}$ & 58.7 & $1.405 \pm 0.002$ & 4.034 & 18.8 & $199 \pm 9 \mathrm{ka}$ \\
\hline K-2596 & $\begin{array}{l}\text { SW Snowy volcano. } \\
\text { Top lava flow on SW } \\
\text { Summit, Peak } 6770 .\end{array}$ & 61.4 & $1.740 \pm 0.006$ & 4.899 & 16.5 & $196 \pm 8 \mathrm{ka}$ \\
\hline K-2570 & $\begin{array}{l}\text { SW Snowy volcano. } \\
4000 \text {-ft rim of ice- } \\
\text { mantled lava flow, } \\
5.2 \mathrm{~km} \text { SE. of Peak } \\
6770 .\end{array}$ & 57.9 & $1.217 \pm 0.003$ & 1.618 & 6.8 & $92 \pm 10 \mathrm{ka}$ \\
\hline
\end{tabular}


Table 2. Estimated phenocryst contents of eruptive products of Snowy Mountain volcanic center.

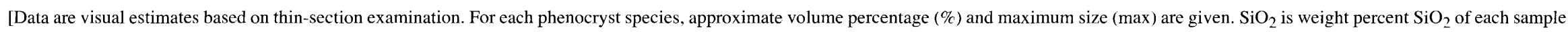

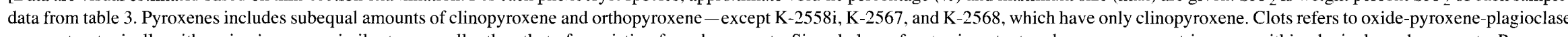

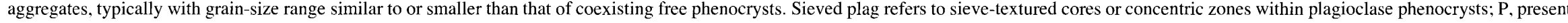
in a few grains; C, common in many grains (but not most). Cone ( $\mathrm{NE}$ or $\mathrm{SW}$ ) and sector are given to assist reader in locating sample number on figure 2]

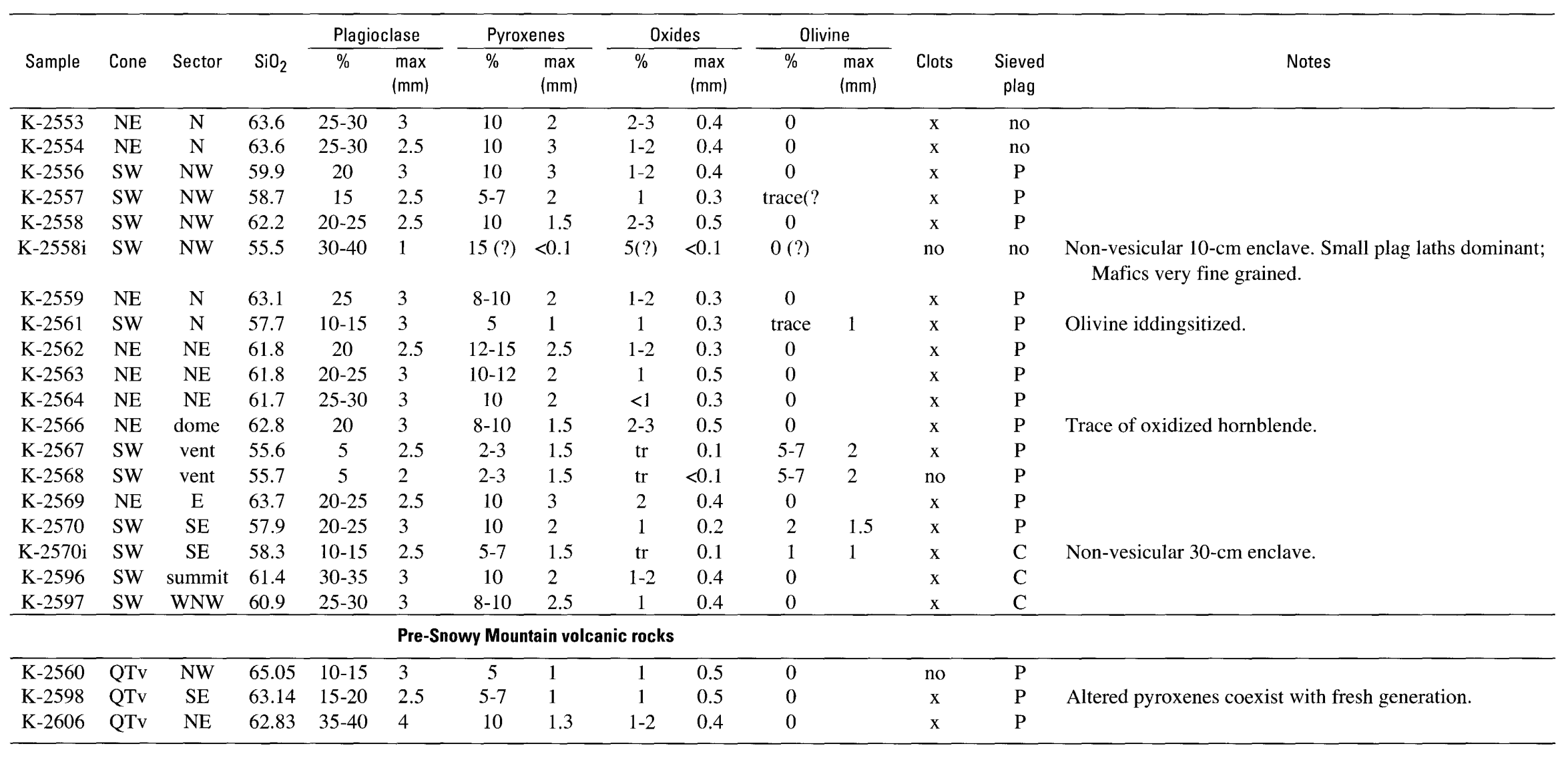


Table 3. Chemical analyses of eruptive products.

[The ten major oxides (reported in weight percent) are normalized to $\mathrm{H}_{2} \mathrm{O}$-free totals of 99.6 weight percent (allowing 0.4 weight percent for trace oxides and halogens). Determinations by wavelength-dispersive XRF in USGS laboratory at Lakewood, Colorado; D.F. Siems, analyst. Precision and accuracy are discussed by Bacon and Druitt (1988) and Baedecker (1987). FeO* is total iron calculated as FeO. "Original total" is the volatile-free sum of the ten oxides, as analyzed, before normalization, with total iron calculated as $\mathrm{Fe}_{2} \mathrm{O}_{3}$. LOI, weight loss on ignition at $900^{\circ} \mathrm{C}$. Cone and sector are given to assist reader in locating sample number on figure 2]

\begin{tabular}{|c|c|c|c|c|c|c|c|c|c|c|c|c|c|c|}
\hline Sample & Cone & Sector & $\mathrm{SiO}_{2}$ & $\mathrm{TiO}_{2}$ & $\mathrm{Al}_{2} \mathrm{O}_{3}$ & $\mathrm{FeO}^{*}$ & $\mathrm{MnO}$ & $\mathrm{MgO}$ & $\mathrm{CaO}$ & $\mathrm{Na}_{2} \mathrm{O}$ & $\mathrm{K}_{2} \mathrm{O}$ & $\mathrm{P}_{2} \mathrm{O}_{5}$ & LOI & $\begin{array}{c}\text { Origina } \\
\text { total }\end{array}$ \\
\hline \multicolumn{15}{|c|}{ Snowy Mountain } \\
\hline K-2553 & $\mathrm{NE}$ & $\mathrm{N}$ & 63.6 & 0.69 & 15.74 & 5.67 & 0.11 & 2.69 & 5.36 & 3.62 & 1.92 & 0.21 & 0.54 & 98.83 \\
\hline K-2554 & $\mathrm{NE}$ & $\mathrm{N}$ & 63.6 & 0.67 & 15.84 & 5.51 & 0.11 & 2.71 & 5.45 & 3.62 & 1.91 & 0.20 & 0.03 & 99.33 \\
\hline K-2556 & SW & NW & 59.9 & 0.70 & 16.67 & 6.54 & 0.12 & 3.83 & 6.77 & 3.41 & 1.46 & 0.19 & -0.04 & 99.68 \\
\hline K-2557 & SW & NW & 58.7 & 0.70 & 16.69 & 6.86 & 0.13 & 4.32 & 7.41 & 3.25 & 1.34 & 0.18 & -0.14 & 99.47 \\
\hline K-2558 & SW & NW & 62.2 & 0.66 & 16.11 & 5.89 & 0.12 & 3.17 & 6.01 & 3.50 & 1.72 & 0.18 & 0.11 & 99.16 \\
\hline K-2558i & SW & NW & 55.5 & 0.75 & 17.41 & 8.08 & 0.14 & 5.18 & 8.71 & 2.73 & 1.03 & 0.12 & 0.24 & 99.18 \\
\hline $\mathrm{K}-2559$ & $\mathrm{NE}$ & $\mathrm{N}$ & 63.1 & 0.62 & 16.51 & 5.54 & 0.10 & 2.84 & 5.42 & 3.55 & 1.76 & 0.18 & 1.27 & 98.48 \\
\hline K-2561 & SW & $\mathrm{N}$ & 57.7 & 0.74 & 16.88 & 7.15 & 0.13 & 4.89 & 7.46 & 3.27 & 1.21 & 0.18 & 0.49 & 99.01 \\
\hline K-2562 & $\mathrm{NE}$ & $\mathrm{NE}$ & 61.8 & 0.61 & 16.56 & 5.72 & 0.12 & 3.26 & 6.11 & 3.66 & 1.55 & 0.20 & 0.25 & 98.20 \\
\hline K-2563 & $\mathrm{NE}$ & $\mathrm{NE}$ & 61.8 & 0.60 & 16.75 & 5.69 & 0.11 & 3.21 & 6.01 & 3.70 & 1.51 & 0.20 & 0.26 & 99.45 \\
\hline K-2564 & $\mathrm{NE}$ & NE & 61.7 & 0.61 & 16.58 & 5.77 & 0.12 & 3.32 & 6.09 & 3.65 & 1.52 & 0.20 & 0.26 & 99.31 \\
\hline K-2566 & $\mathrm{NE}$ & dome & 62.8 & 0.57 & 16.49 & 5.21 & 0.11 & 3.02 & 5.88 & 3.79 & 1.53 & 0.19 & 0.41 & 99.29 \\
\hline K-2567 & SW & vent & 55.6 & 0.70 & 16.21 & 7.16 & 0.13 & 7.16 & 8.50 & 3.08 & 0.85 & 0.20 & 0.36 & 99.18 \\
\hline K-2568 & SW & vent & 55.7 & 0.69 & 16.18 & 7.14 & 0.13 & 7.14 & 8.47 & 3.04 & 0.87 & 0.20 & 0.35 & 98.90 \\
\hline K-2569 & $\mathrm{NE}$ & $\mathrm{E}$ & 63.7 & 0.61 & 16.08 & 5.22 & 0.11 & 2.75 & 5.47 & 3.78 & 1.72 & 0.20 & 0.19 & 99.17 \\
\hline K-2570 & SW & SE & 57.9 & 0.72 & 16.81 & 6.59 & 0.13 & 4.88 & 7.82 & 3.37 & 1.13 & 0.21 & 0.49 & 99.38 \\
\hline K-2570i & SW & SE & 58.3 & 0.74 & 16.44 & 6.56 & 0.12 & 5.10 & 7.82 & 3.16 & 1.29 & 0.13 & 0.68 & 99.05 \\
\hline K-2596 & SW & summit & 61.4 & 0.67 & 16.17 & 6.14 & 0.12 & 3.46 & 6.37 & 3.49 & 1.63 & 0.18 & 0.04 & 99.15 \\
\hline K-2597 & SW & WNW & 60.9 & 0.71 & 16.91 & 6.10 & 0.12 & 3.13 & 6.43 & 3.59 & 1.54 & 0.20 & 1.00 & 98.35 \\
\hline \multicolumn{15}{|c|}{ Pre-Snowy Mountain volcanic rocks } \\
\hline K-2560 & QTv & $\mathrm{NW}$ & 65.0 & 0.52 & 16.11 & 4.41 & 0.09 & 2.49 & $5 . \overline{54}$ & 3.79 & 1.38 & 0.22 & 1.71 & 97.69 \\
\hline K-2598 & QTv & SE & 63.1 & 0.68 & 15.89 & 5.16 & 0.10 & 3.74 & 5.53 & 3.61 & 1.56 & 0.19 & 1.81 & 97.17 \\
\hline K-2606 & QTv & NE & 62.8 & 0.65 & 16.37 & 4.91 & 0.09 & 3.30 & 5.89 & 3.89 & 1.47 & 0.18 & 2.16 & 97.33 \\
\hline
\end{tabular}

several percent olivine phenocrysts as large as $2 \mathrm{~mm}$. Amphibole was found only in the Holocene lava dome, and in our sample it is rare and opacitized. Quartz, sanidine, and biotite are absent. Groundmass textures are normal for intermediate lavas, ranging typically from partly glassy and vesicular in ejecta and in flow exteriors to crystalline and massive in thick flow interiors. As in many andesites, the plagioclase phenocrysts typically make up two or several coexisting populations. Some crystals are weakly zoned and relatively uncomplicated whereas others variously exhibit oscillatory zoning, dissolution surfaces with overgrowths, sieve-textured zones or cores, intergrowths with other grains, or polycrystalline clots (usually including pyroxenes and oxides). Such complexity preserves evidence for multistage pre-eruptive thermal and ascent histories generally involving magma mixing and remobilization of stalled crystallizing batches (e.g., Singer and others, 1995; Coombs and others, 2000).

Major-element determinations by X-ray fluorescence spectroscopy are given for 19 Snowy Mountain samples in table 3; the data are illustrated in figure 11 and the sample locations shown in figure $2 B$. Four additional analyses (fig. 11) of samples said to be from Snowy Mountain were tabulated by Kienle and others (1983), but neither sample locations, analytical methods, nor laboratory were specified. No other chemical data for the Snowy Mountain volcanic center are known to us.

All Snowy Mountain samples plot in the medium-K field (fig. 11A) and far into the calcalkaline field on a conventional FeO*/MgO vs. $\mathrm{SiO}_{2}$ diagram (fig. $11 B$ ). An alkali-lime intersection (fig. $11 C$ ) at 63.5 percent $\mathrm{SiO}_{2}$ defines a calcic suite (Peacock, 1931), as previously also determined for Novarupta (Hildreth, 1983) and for nearby Mageik, Martin, and Alagogshak volcanoes (Hildreth and others, 1999; 2000). The $\mathrm{SiO}_{2}$ contents of lava flows range from 55.6 to 63.7 percent, and the two magmatic enclaves analyzed gave 55.5 and 58.3 percent. This range is comparable to those of suites from Trident, 


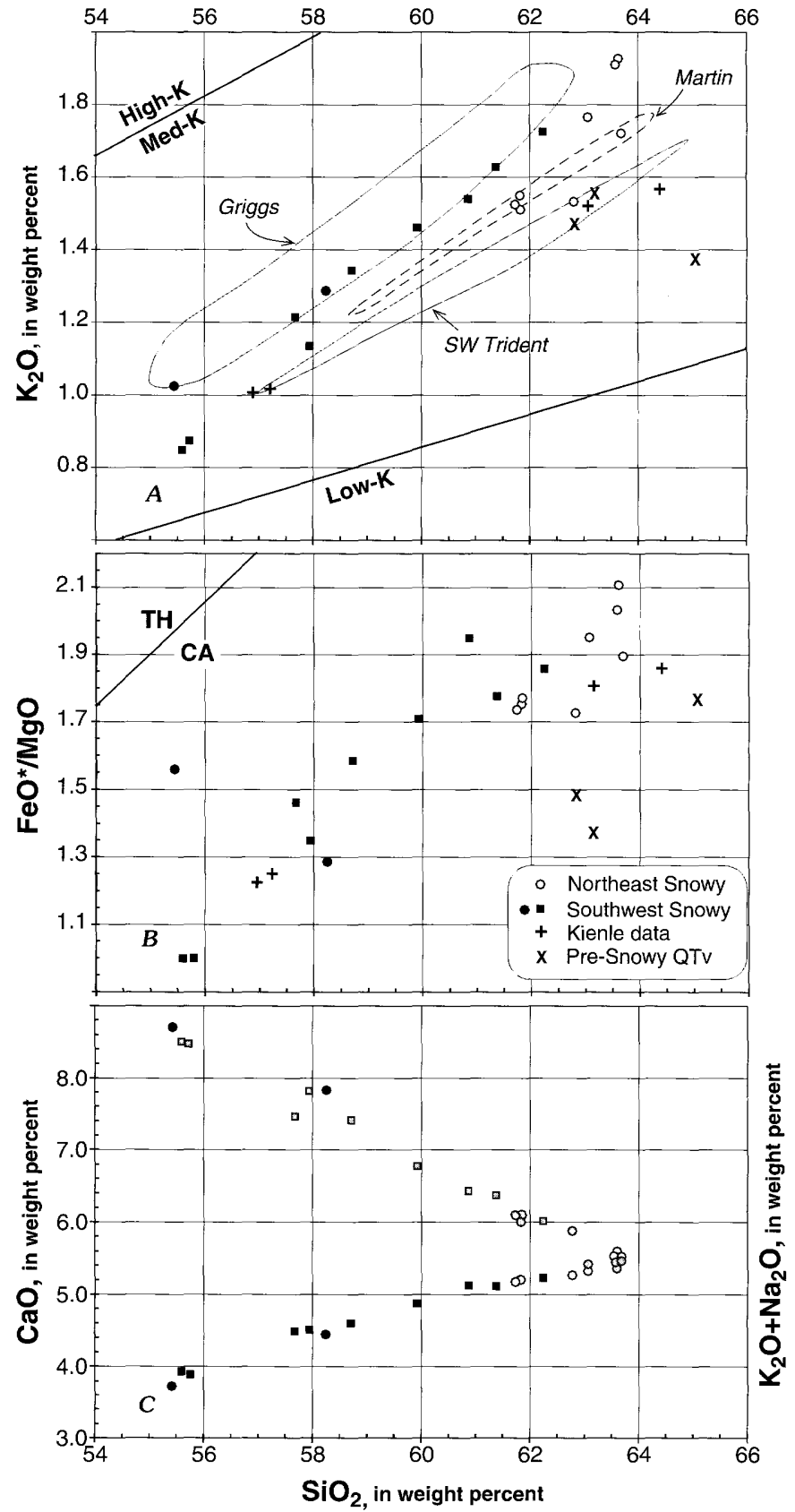

Figure 11. Whole-rock compositional data for Snowy Mountain samples as identified in inset. Filled circles for Southwest Snowy are magmatic enclaves (tables 2, 3). "Kienle data" $(+)$ are four analyses reported by Kienle and others (1983) for unlocated samples said to have been taken from Snowy Mountain. In addition to Snowy data, fields outlining the compositional ranges determined for our suites of samples from nearby Mount Griggs ( $n=75)$, Mount Martin $(n=13)$, and Southwest (New) Trident $(n=15)$ are shown for comparison. $A$, $\mathrm{K}_{2} \mathrm{O}$ vs. $\mathrm{SiO}_{2}$. $B, \mathrm{FeO}^{*} / \mathrm{MgO}$ vs. $\mathrm{SiO}_{2}$. $C, \mathrm{CaO}$ (upper array) and total alkalis (lower array) vs. $\mathrm{SiO}_{2}$. Data from Hildreth and others (1999, 2000); Hildreth and Fierstein (2000); and table 3 of this report. TH/CA is conventional field boundary between tholeiitic and calcalkaline suites. $\mathrm{FeO}^{*}$ is total iron calculated as $\mathrm{FeO}$. The nomenclatural division between andesite and dacite lies at 63 percent $\mathrm{SiO}_{2}$ and is simply a conventional tick on a natural continuum in many arc suites.
Martin, and Alagogshak but much more restricted than those of Novarupta and Mount Katmai (Hildreth, 1987; Hildreth and others, 1999; Hildreth and Fierstein, 2000). Snowy Mountain eruptive products form a typical low-Ti arc suite, containing only $0.57-0.75$ percent $\mathrm{TiO}_{2}$. Contents of $\mathrm{Al}_{2} \mathrm{O}_{3}$ are ordinary for arc suites, ranging from 15.7 to 17.4 percent. Relatively primitive material has not erupted at Snowy Mountain, most samples having less than 5.2 percent $\mathrm{MgO}$, but (at 7.1 percent $\mathrm{MgO}$ ) the olivine-bearing scoria blocks from the vent complex of Southwest Snowy do rank among the most magnesian Quaternary volcanic products yet recognized in the Katmai district.

Figure 11 shows that products of Southwest Snowy (55.5-62.2 percent $\mathrm{SiO}_{2}$ ) are generally less silicic than those of Northeast Snowy (61.7-63.7 percent $\mathrm{SiO}_{2}$ ) and that they also tend to have slightly higher $\mathrm{K}_{2} \mathrm{O}$ at equivalent values of $\mathrm{SiO}_{2}$. The Holocene lava dome (at $62.8 \mathrm{SiO}_{2}, 1.53 \mathrm{~K}_{2} \mathrm{O}$; fig. $11 \mathrm{~A}$ ) is less silicic than several older lava flows from Northeast Snowy and is, relatively, one of the least potassic.

Three samples of the highly eroded basement volcanic suite directly underlying the Snowy Mountain lavas were studied and analyzed (tables 2, 3). All three are pyroxene dacites, petrographically and chemically rather similar to silicic members of the Snowy Mountain suite, though relatively less potassic and distinctively more hydrated (see LOI, table 3). Thought to be of early Quaternary or late Tertiary age, these rocks are slightly altered remnants of a previous generation of arc volcanoes that apparently lay along or close to the same alignment as that of the modern volcanic chain (figs. 1,2).

\section{Volume Estimates}

Owing to the extensive glacial erosion and the presentday ice blanket, estimates of eruptive volume are not very accurate for these cones. Exposures of Quaternary volcanic rocks today add up to about $6.5 \mathrm{~km}^{2}$ for Northeast Snowy and only $2.4 \mathrm{~km}^{2}$ for Southwest Snowy. Extrapolation beneath the ice between outcrops yields minimum areas originally lavacovered of $31 \mathrm{~km}^{2}$ and $36 \mathrm{~km}^{2}$, respectively. Conservative estimates of lost volumes of distal lavas, not counting probable intracanyon lava tongues, could raise total areas to $40 \mathrm{~km}^{2}$ and $45 \mathrm{~km}^{2}$, respectively.

For converting such areas to volume estimates, a cone model is inappropriate because the volcanoes straddle a narrow rangecrest ridge of pre-Quaternary basement rocks and because their bilaterally emplaced lavas draped irregularly rugged topography on both flanks. Along the main drainage divide, Tertiary rocks crop out as high as 5,500 ft only $1 \mathrm{~km}$ east of the vent-plugging 6,875-ft dome of Northeast Snowy and as high as $6,000 \mathrm{ft}$ only $1.5 \mathrm{~km}$ west of the vent of Southwest Snowy (fig. 2). Although Snowy Mountain lavas are preserved on the north flank down to elevations as low as 2,000 $\mathrm{ft}$, they are flanked there by ridges of basement rocks higher in several places than $4,000 \mathrm{ft}$. The volume approximation is best treated, therefore, in several parts - two thick near-vent 
piles and several separate stacks of outflow lavas that infilled paleotopography north and south of the divide.

The thick proximal part of the Northeast Snowy cone had an original area of about $10 \mathrm{~km}^{2}$ and that of the Southwest Snowy cone about $6 \mathrm{~km}^{2}$. The present-day summits, Peaks 7090 and 6770 , respectively, do not appear on structural grounds to be eroded much below their original elevations. If this be true, primary relief on the two proximal piles might have averaged about $650 \mathrm{~m}$ and $450 \mathrm{~m}$, respectively. On this basis, cone-model calculations yield volumes of $2.2 \mathrm{~km}^{3}$ for the northeast proximal pile and $0.9 \mathrm{~km}^{3}$ for the southwest.

Volumes of outflow stacks are even harder to approximate because the deeply incised (pre-volcano) bedrock surface is so discontinuously exposed beneath the lavas and ice. Where they issue from the proximal piles some lava-flow stacks appear to be $400-600 \mathrm{~m}$ thick, but (in contrast to individual lava flows that commonly thicken downslope) the stacks tend to thin distally, probably owing to spreading and shingling during outflow and to more rapid erosion along paleovalleys. At their eroded termini today, radially emplaced stacks of lava flows are no thicker than $300 \mathrm{~m}$ on the north slope and as thin as $100-150 \mathrm{~m}$ on the south slope. On the basis of all these weakly constraining observations, we estimate the original outflow volume of Northeast Snowy to have been in the range 4-8 $\mathrm{km}^{3}$ and that of Southwest Snowy in the range $3-6 \mathrm{~km}^{3}$. Adding these crude estimates to the proximal-pile volumes given above yields $8 \pm 3 \mathrm{~km}^{3}$ for the northeastern edifice, $5 \pm 2$ $\mathrm{km}^{3}$ for the southwestern, and an eruptive volume of $13 \pm 4 \mathrm{~km}^{3}$ for the Snowy Mountain center as a whole. Only half to twothirds of this material has survived glacial erosion and remains in place on the skeletally sculpted edifices today.

\section{Discussion}

Snowy Mountain is a small andesite-dacite arc volcano that apparently originated at least $200 \mathrm{k} . \mathrm{y}$. ago. Eruptions have taken place from two vents $4 \mathrm{~km}$ apart. Their eruptive lifetimes overlapped extensively, though only the northeastern vent has erupted in the Holocene. Products of the southwestern vent are generally more mafic than those of the northeastern, which extend to dacite. No dacitic pumice deposits were seen proximally, and no regionally widespread ash layer has been tied to Snowy Mountain. Although we found no evidence for major explosive events, the modern ice cover and the recurrent regional glaciations of the past dissuade us from concluding firmly that no such activity ever took place here during the Pleistocene.

The modest eruptive volume $\left(13 \pm 4 \mathrm{~km}^{3}\right)$ and the longevity of the volcano $(199 \pm 9 \mathrm{k} . \mathrm{y}$.) make the calculation of an average volumetric eruption rate $\left(0.04-0.09 \mathrm{~km}^{3} / \mathrm{k}\right.$.y.) a potentially misleading exercise. Nominally, the lifetime average eruption rate for Snowy Mountain is similar to that estimated for each of the cones of Trident volcano (fig. 1), but it is 3-10 times smaller than the long-term rates for Mounts Mageik and Katmai (Hildreth and Fierstein, 2000; Hildreth and others, 2000). Many or most andesite-dacite stratovolcanoes, however, erupt in spurts (Hildreth and Lanphere, 1994), and there is little evidence for volumetrically steady-state production, storage, or eruption of magma at such centers. At the extreme, $13 \mathrm{~km}^{3}$ of magma (equivalent to the entire volume of Snowy Mountain) erupted at nearby Novarupta in 60 hours in June of 1912 (Fierstein and Hildreth, 1992).

Accordingly, the evidence (albeit modest and inconclusive) at Snowy Mountain suggests that much of its eruptive volume could have been produced during a limited number of events widely separated in time. The pair of Snowy Mountain cones consist altogether of only about 25-30 lava flows, so even if these were ideally spaced, gaps between eruptions would be as long as 6,000 years. Pairs or stacks of conformable lava flows of closely similar composition suggest that there were in reality far fewer eruptive episodes and therefore at least some breaks much longer in duration. (This analysis ignores minor ash outbursts that leave no substantial depositional record in such terrain.) Production of multi-flow stacks during episodes lasting a few years to decades is a common mode of stratovolcano behavior, as illustrated locally by the eruption in 1953-60 of four overlapping andesite-dacite lava flows at Southwest Trident volcano (Hildreth and others, 2000; Coombs and others, 2000).

Another example is Mount Martin, $40 \mathrm{~km}$ southwest of Snowy Mountain (fig. 1), which consists of a small fragmental cone and a staircase of 10 overlapping coulees of blocky dacite, each 75-100 m thick, that descend northwestward for $10 \mathrm{~km}$. The extremely asymmetrical distribution of lava flows with respect to the summit vent (fig. 12) resembles the stacked array of Southwest Trident, the Holocene array of flows from the East Summit of Mount Mageik (Hildreth and others, 2000), and the staircase of flows on the north side of Snowy Mountain (fig. 12). Interflow conformity within parts of such stacks and the compositional similarities of subsets of successive flows within such stacks suggest rapid sequential emplacement. At Mount Martin, the whole pile is Holocene and much or all of it could have erupted on a timescale of decades to centuries (fig. 12). At Snowy Mountain, the three thick conformable dacites at the bottom of the stack (fig. 12) could likewise have been emplaced in rapid succession.

The small adjacent cones of Snowy Mountain are characteristic of late Quaternary andesite-dacite arc volcanism in the Katmai volcanic district. Along the same rangecrest (fig. 1), four discrete cones of Mount Mageik, four cones of Trident, and two of Mount Katmai, as well as Alagogshak volcano, Mount Martin, and several peripheral lava domes, form a chain only $30 \mathrm{~km}$ long, display eruptive volumes of $1-30 \mathrm{~km}^{3}$ each, and have mutual spacings of only $1-8 \mathrm{~km}$. The close-set array of small cones contrasts strikingly with such giant stratocones as Veniaminof and Shishaldin (each well over $100 \mathrm{~km}^{3}$ ) farther down the chain, and it conflicts with the conventional myth of evenly spaced arc volcanoes $40-70 \mathrm{~km}$ apart. Additional, comparably close-set arrays of stratovolcanoes on the Alaska Peninsula include the Pavlof and Stepovak Bay groups (Wood 
and Kienle, 1990) and, just northeast of Snowy Mountain (fig. 1), the Denison-Steller-Kukak-Devils Desk chain. Although the last-named chain is very poorly known, eruptive volumes of the four contiguous cones probably fall in the range 5-15 $\mathrm{km}^{3}$ each, and the mutual spacing of their vents is $3-4 \mathrm{~km}$. (Mount Steller is not even spelled correctly on many published maps; it is named for Georg Wilhelm Steller, 1709-1746, naturalist on the 1741 voyage of Vitus Bering.)

Why are so many, closely spaced, mostly small, andesitedacite volcanoes perched directly atop the peninsular drainage divide from Alagogshak to Devils Desk (fig. 1)? It has been suggested (e.g., Keller and Reiser, 1959; Kienle and others, 1983) that the volcanic chain in the Katmai district is built on the crest of a regional anticline in the Mesozoic basement rocks. Examination of the geologic map and structural cross sections of Riehle and others (1993), however, shows that the volcanoes do not necessarily lie right along the ill-defined structural crest and that the "anticline" is at best a broad regional warp defined by strata dipping only $5^{\circ}-20^{\circ}$ and complicated by a variety of oblique lesser folds. Additionally complicated by the intrusion of numerous Tertiary plutons into the warped Mesozoic strata, it seems very unlikely that any such upper-crustal structure controls the linear alignment of the Quaternary volcanic chain illustrated in figure 1. Alternatives to upper-crustal control include (1) a narrowly linear pattern of fluid release from the subducting slab, (2) a sharp convecting corner or some other mechanism producing a narrowly linear curtain of magma generation and ascent in the mantle wedge, or (3) some linear structure in the deep crust that traps and stores mantle-derived magma batches long enough for assimilation, fractionation, and admixture of local partial melts to reestablish buoyant ascent (Hildreth and Moorbath, 1988). The observation that Mount Griggs, a 20- to $25-\mathrm{km}^{3}$ stratovolcano $12 \mathrm{~km}$ behind the main volcanic chain (fig. 1) has produced an eruptive suite significantly more potassic (fig. 11) than any of the contemporaneous centers along the chain
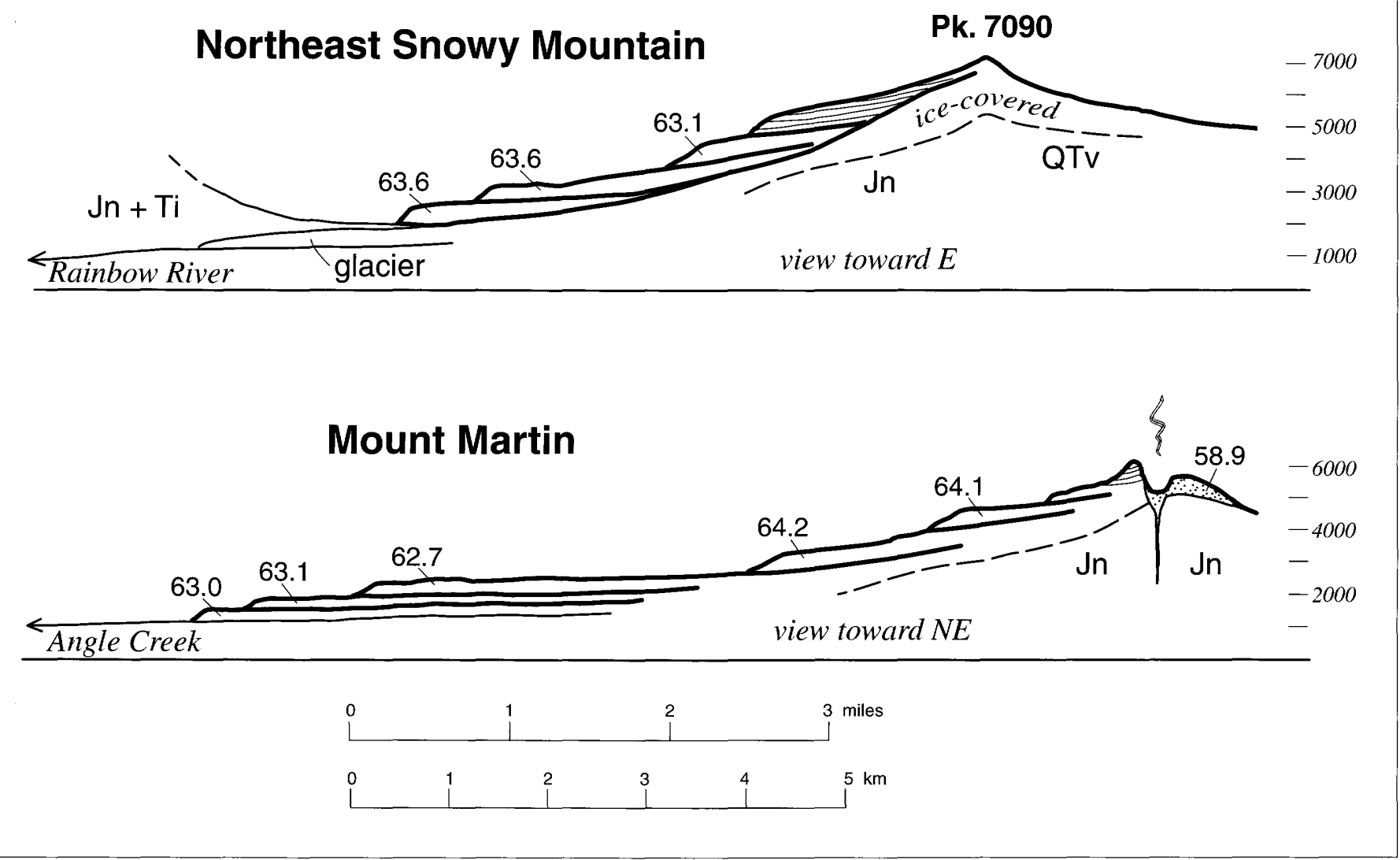

Figure 12. Comparative profiles of conformable staircase stacks of dacitic lava flows on north flanks of Snowy Mountain and Mount Martin, which lie along the same rangecrest $44 \mathrm{~km}$ apart (fig. 1). Weight percent $\mathrm{SiO}_{2}(63,64)$ is indicated for most flows. Although lavas of the two centers are compositionally similar (fig. 11), the three distal coulees from Northeast Snowy are 150-200 m thick, those from Mount Martin about $100 \mathrm{~m}$ thick. Lavas higher in the stacks are thinner at Northeast Snowy, thicker at Mount Martin. Elevations are in feet $(1 \mathrm{~m}=3.28 \mathrm{ft}$. No vertical exaggeration. Jn, Jurassic Naknek Formation; Ti, Tertiary intrusive rocks; QTv, pre-Snowy Mountain altered volcanic rocks. 
itself generally supports the notion of deep influence. Perhaps an unusually narrow belt of magma storage in the deep crust or mantle-crust transition zone leads to some degree of mixing and modulation of any mantle-derived compositional diversity beneath the main chain. Antecedent to renewed dike transport toward the upper crust and distribution into discrete eruptive centers, such deep-crustal storage and modulation might account for the grossly similar compositional trends of Snowy Mountain and many of the Katmai cluster volcanoes nearby (Hildreth and Fierstein, 2000).

Although the along-arc distribution of andesite-dacite magma into many small, close-set eruptive centers, as observed in the Katmai district and in a few other stretches of the Alaska Peninsula-Aleutian arc, is not a general feature of the whole Quaternary arc, the extremely linear arrangement is. The single-file chain of volcanoes that stretches $2,500 \mathrm{~km}$ from Cook Inlet to Buldir Island (Miller and others, 1998) contrasts drastically with the Japanese, Cascadian, Mexican, and Andean arcs, where the Quaternary volcanic zones are typically several tens of kilometers wide and where numerous volcanoes scatter far behind the volcanic front. In the Alaska Peninsula-Aleutian arc, instead of hundreds of volcanoes behind the volcanic front, there are only a handful of Quaternary centers (e.g., Griggs, Ukinrek, Amak, and Bogoslof; Simkin and Siebert, 1994). Although offsets of alignment do divide the chain into several segments, some process or deep structure imposes on this arc an extraordinarily narrow linearity that is not typical of arcs worldwide.

\section{Volcano Hazards}

The principal volcano hazards in this wilderness region are to aviation, fish and wildlife resources, and backcountry travelers. The volcano is so remote that a future eruption as large as any past event at Snowy Mountain is unlikely to have any impact on ground-based people or property. Another large debris avalanche might muddy the waters in a coastal harbor or downstream on the Savonoski River for a season or two. The principal danger is from phreatomagmatic and magmatic eruptions that can reasonably be anticipated to produce ash clouds that could rise to altitudes of 5-12 km, i.e., as high as $40,000 \mathrm{ft}$, endangering any passing aircraft. It is unlikely that ashfall from such an eruption at Snowy Mountain would produce more than a light dusting at Kodiak or Cook Inlet settlements. Many other volcanoes nearby are characteristically more explosive than Snowy Mountain appears to have been and thus pose greater ash-cloud hazards to aviation.

In all probability, renewed eruptive activity at Snowy Mountain or any of its companion volcanoes would be preceded by days to months of increased seismicity. A persistent cluster of shallow earthquakes north and west of Snowy Mountain has been recognized since at least 1965 (Ward and others, 1991), at depths of 5-10 km in basement rocks, 5-20 km from the volcanic line. A few shallow earthquakes (magnitudes
1-2) have also taken place beneath or close to the Snowy Mountain edifice itself. In 1998, Alaska Volcano Observatory (AVO) expanded its Katmai seismic network to deploy several seismometers north of Snowy Mountain, thus sharpening the precision of locating small earthquakes and improving the ability to detect seismic activity potentially precursory to eruptions. Were signs of unrest to be detected, AVO would implement additional instrumental and observational monitoring and would notify various authorities, the media, and the aviation community of the impending hazard.

\section{Acknowledgments}

Tracey Felger and Dave Tucker helped with the fieldwork, James Saburomaru and Forrest McFarland with K-Ar dating, and John Paskievitch with field logistics. Helicopter pilots Bill Springer and Jim Sink took us safely to outcrops that would have been a helluva hike. We thank Game McGimsey and Manuel Nathenson for careful reviews of the manuscript.

\section{References Cited}

Bacon, C.R., and Druitt, T.H., 1988, Compositional evolution of the zoned calcalkaline magma chamber of Mount Mazama, Crater Lake, Oregon: Contributions to Mineralogy and Petrology, v. 98, p. 224-256.

Baedecker, P.A., ed., 1987, Methods for geochemical analysis: U.S. Geological Survey Bulletin 1770.

Coombs, M.L., Eichelberger, J.C., and Rutherford, M.J., 2000, Magma storage and mixing conditions for the 1953 eruptions of Southwest Trident volcano, Katmai National Park, Alaska: Contributions to Mineralogy and Petrology, v. 140, p. 99-118.

Detterman, R.L., Case, J.E., Miller, J.W., Wilson, F.H., and Yount, M.E., 1996, Stratigraphic framework of the Alaska Peninsula: U.S. Geological Survey Bulletin 1969-A, $74 \mathrm{p}$.

Fierstein, J., and Hildreth, W., 1992, The plinian eruptions of 1912 at Novarupta, Katmai National Park, Alaska: Bulletin of Volcanology, v. 54, p. $646-684$.

Griggs, R.F., 1922, The Valley of Ten Thousand Smokes: Washington, D.C., National Geographic Society, 340 p.

Hildreth, W., 1983, The compositionally zoned eruption of 1912 in the Valley of Ten Thousand Smokes, Katmai National Park, Alaska: Journal of Volcanology and Geothermal Research, v. 18, p. 1-56.

Hildreth, W., 1987, New perspectives on the eruption of 1912 in the Valley of Ten Thousand Smokes, Katmai National Park, Alaska: Bulletin of Volcanology, v. 49, p. 680-693.

Hildreth, W., 1991, The timing of caldera collapse at Mount Katmai in response to magma withdrawal toward Novarupta: Geophysical Research Letters, v. 18, p. 1541-1544. 
Hildreth, W., and Fierstein, J., 2000, The Katmai volcanic cluster and the great eruption of 1912: Geological Society of America Bulletin, v. 112, p. $1594-1620$.

Hildreth, W., and Lanphere, M.A., 1994, Potassium-argon geochronology of a basalt-andesite-dacite arc system: The Mount Adams volcanic field, Cascade Range of southern Washington: Geological Society of America Bulletin, v. 106, p. 1413-1429.

Hildreth, W., and Moorbath, S., 1988, Crustal contributions to arc magmatism in the Andes of central Chile: Contribution to Mineralogy and Petrology, v. 98, p. 455-489.

Hildreth, W., Fierstein, J., Lanphere, M.A., and Siems, D.F., 1999, Alagogshak volcano: A Pleistocene andesite-dacite stratovolcano in Katmai National Park, in Kelley, K.D., ed., Geologic Studies in Alaska by the U.S. Geological Survey, 1997: U.S. Geological Survey Professional Paper 1614, p. 105-113.

Hildreth, W., Fierstein, J., Lanphere, M.A., and Siems, D.F., 2000, Mount Mageik: A compound stratovolcano in Katmai National Park, in Kelley, K.D., and Gough, L.P., eds., Geologic Studies in Alaska by the U.S. Geological Survey, 1998: U.S. Geological Survey Professional Paper 1615, p. 23-42.

Jolly, A.D., and McNutt, S.R., 1999, Seismicity at the volcanoes of Katmai National Park, Alaska; July 1995-December 1997: Journal of Volcanology and Geothermal Research, v. 93, p. 173-190.

Keller, A.S., and Reiser, H.N., 1959, Geology of the Mount Katmai area, Alaska: U.S. Geological Survey Bulletin 1058-G, p. 261-298; map scale $1: 250,000$.

Kienle, J., Swanson, S.E., and Pulpan, H., 1983, Magmatism and subduction in the eastern Aleutian arc, in Shimozuru, D., and Yokoyama, I., eds., Arc Volcanism: Physics and Tectonics: Tokyo, Terra Scientific Publishing Company, p. 191-224.

Miller, T.P., McGimsey, R.G., Richter, D.H., Riehle, J.R., Nye, C.J., Yount, M.E., and Dumoulin, J.A., 1998, Catalog of the historically active volcanoes of Alaska: U.S. Geological Survey Open-File Report 98-582, $104 \mathrm{p}$.

Mann, D.H., and Peteet, D.M., 1994, Extent and timing of the Last Glacial Maximum in southwestern Alaska: Quaternary Research, v. 42 , p. 136-148.

Motyka, R.J., Liss, S.A., Nye, C.J., and Moorman, M.A., 1993, Geothermal resources of the Aleutian arc: Alaska Division of Geological \& Geophysical Surveys Professional Report 114, $17 \mathrm{p}$.
Peacock, M.A., 1931, Classification of igneous rock series: Journal of Geology, v. 39, p. 54-67.

Riehle, J.R., and Detterman, R.L., 1993, Quaternary geologic map of the Mount Katmai quadrangle and adjacent parts of the Naknek and Afognak quadrangles, Alaska: U.S. Geological Survey Map I-2032, scale 1:250,000.

Riehle, J.R., Detterman, R.L., Yount, M.E., and Miller, J.W., 1993, Geologic map of the Mount Katmai quadrangle and adjacent parts of the Naknek and Afognak quadrangles, Alaska: U.S. Geological Survey Map I-2204, scale 1:250,000.

Shew, N., and Lanphere, M.A., 1992, Map showing potassium-argon ages from the Mount Katmai and adjacent parts of the Naknek and Afognak quadrangles, Alaska Peninsula, Alaska: U.S. Geological Survey Miscellaneous Field Studies Map MF-2021-E, scale $1: 250,000$.

Simkin, T., and Siebert, L., 1994, Volcanoes of the world: Tucson, Ariz., Geoscience Press, 349 p.

Singer, B.S., Dungan, M.A., and Layne, G.D., 1995, Textures and Sr, $\mathrm{Ba}, \mathrm{Mg}, \mathrm{Fe}, \mathrm{K}$, and $\mathrm{Ti}$ compositional profiles in volcanic plagioclase: Clues to the dynamics of calc-alkaline magma chambers: American Mineralogist, v. 80, p. 776-798.

Stacey, J.S., Sherrill, N.D., Dalrymple, G.B., Lanphere, M.A., and Carpenter, N.V., 1981, A five-collector system for the simultaneous measurement of argon isotope ratios in a static mass spectrometer: International Journal of Mass Spectrometry and Ion Physics, v. 39, p. $167-180$.

Ward, P.L., Pitt, A.M., and Endo, E., 1991, Seismic evidence for magma in the vicinity of Mt. Katmai, Alaska: Geophysical Research Letters, v. 18, p. $1537-1540$.

Wood, C.A., and Kienle, J., eds., 1990, Volcanoes of North America: Cambridge University Press, $354 \mathrm{p}$.

Reviewers: G. McGimsey, M. Nathenson 


\title{
The Insular-Intermontane Suture Zo
of the Western Coast Mountains of
} Southeastern Alaska and British Columbia and the Adria-Europe Suture Zone (AESZ) of Southern Europe-General Description and Comparison of Global-Scale Tectonic Features

\author{
By David A. Brew
}

\section{Abstract}

The western Coast Mountains of southeastern Alaska and British Columbia are marked by a global-scale suture zone, here called the Insular-Intermontane suture zone (IISZ), between the Insular superterrane (west) and the Intermontane superterrane (east). The youngest and most obvious component in the zone is the Coast Range megalineament (CRML). A similar global-scale suture zone in southern Europe, here called the Adria-Europe suture zone (AESZ), is between the European superterrane (north) and the Adriatic superterrane (south) at depth. The Periadriatic lineament (PAL) is the youngest and most obvious component of the AESZ. Both of these suture zones are products of similar processes and have complicated evolutionary histories. They have distinct differences as well as similarities and neither is a simple lithotectonic terrane boundary.

The IISZ is the main unifying geologic element of the western Coast Mountains. From north to south, it transects a variety of local geologic features. The IISZ is as much as $50 \mathrm{~km}$ wide and consists of five in-part-superimposed shear zones. The youngest and most obvious of these zones is the 800-km-long, NNW.-SSE.-trending, <1-km- to several-tensof-kilometers-wide CRML; it is the final expression of a long series of tectonic and intrusive events that occurred near and along the superterrane boundary from the Late Jurassic (or perhaps earlier) through the Cenozoic. The CRML is generally parallel to the strike of the adjacent rocks in the IISZ, bounds contrasting plutonic and metamorphic belts, and has associated geophysical gradients. Recently the term "Coast shear zone" has been used loosely and imprecisely for one or more of the structural elements that make up the IISZ.

The AESZ extends from southern Switzerland eastward into Hungary; it is at least $800 \mathrm{~km}$ long and varies from a NE.-SW. orientation on its west end to E.-W. on its east. The zone records tectonic, metamorphic, and intrusive events that occurred during the Cenozoic near and along the superterrane boundary. The tectonic events included both N.- and S.-directed contractional and E.-W. strike-slip faulting. The youngest of these events produced the crustal-scale geomorphic and structural PAL. Like the CRML, the PAL is parallel to the strike of the adjacent rocks in the AESZ, bounds contrasting plutonic and metamorphic belts, and has associated geophysical gradients.

The original lithotectonic terrane boundaries that are responsible for both the IISZ and the AESZ have been obscured by younger faulting, folding, metamorphic, and magmatic events. Although much more is known about the events in the AESZ than in the IISZ, comparison of the two zones indicates that the tectonic processes that formed them are generally similar. The major differences are that (1) the IISZ has a much longer history of development and few of the original features are preserved - features that would perhaps be comparable to those still preserved in the AESZ; (2) the IISZ has all the original plate boundary thoroughly obscured, whereas the AESZ has the original plate boundary preserved as much of its northern edge; (3) the AESZ contains a much smaller volume of plutonic rocks; and (4) the AESZ is marked by numerous ophiolitic bodies, but the IISZ has none.

\section{Introduction and General Description of the Suture Zones}

There are many global-scale tectonic suture zones exposed on the surface of the Earth, but few form conspicuous lineaments. Of those that do, the Indus-Tsangpo zone north of 

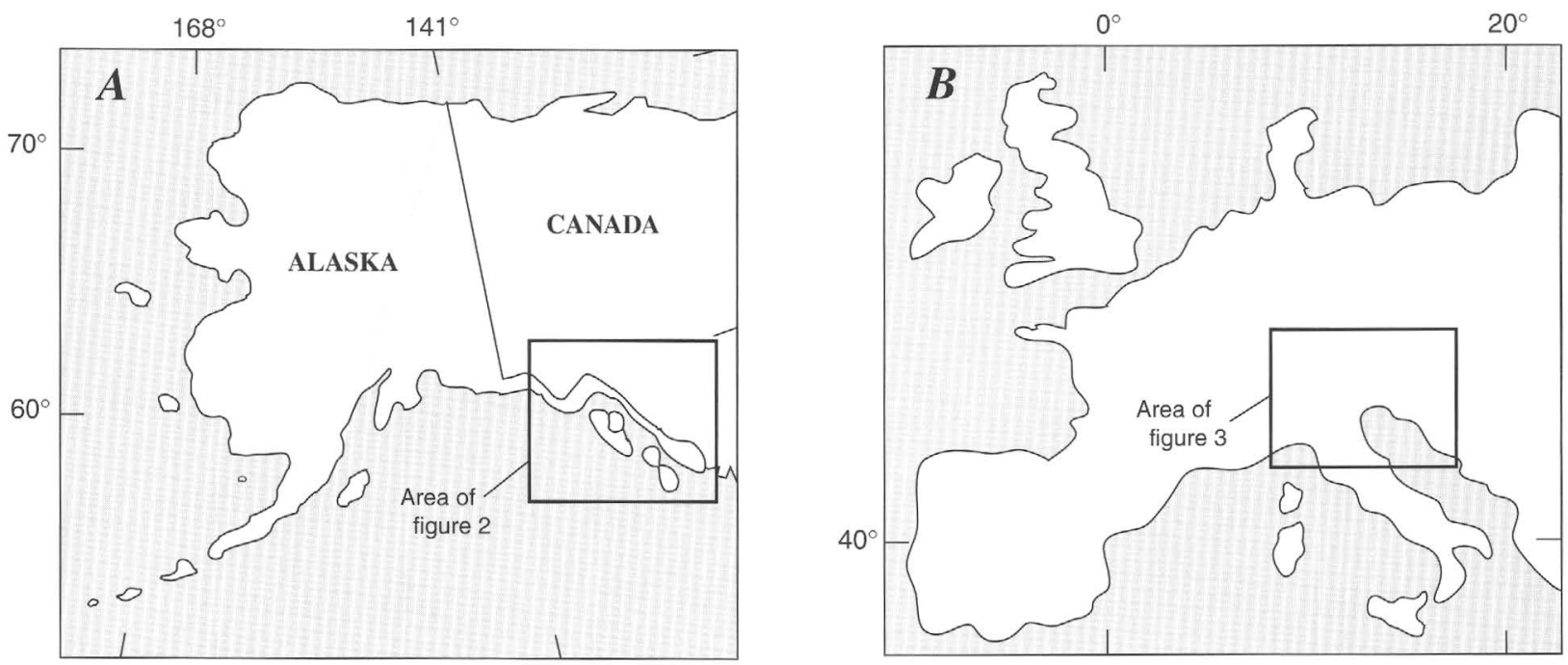

Figure 1. Outline maps showing $A$, Alaska, and $B$, Europe, and the areas covered by figures 2 and 3 . The areas of figures 2 and 3 are approximately the same, with figure 2 being $610 \mathrm{~km}$ both north-south and east-west and figure 3 being approximately 760 kilometers east-west and 590 kilometers north-south.

the Himalaya, the Denali zone of central Alaska, the Alpine fault of New Zealand, the Adria-Europe suture zone (AESZ) of southern Europe, and the Insular-Intermontane suture zone (IISZ) of northwestern North America are perhaps the most prominent (fig. 1). This article describes and compares the IISZ and the AESZ in a general way. For the purposes of this paper, a tectonic suture zone is defined generally as (1) a zone along which two (or more) different tectonic elements (plates or lithotectonic terranes) are juxtaposed; and more specifically as (2) that part of a suture zone where the largest number of events related to the juxtaposition are recorded. This definition thus excludes most foreland and hinterland rocks that were not fully involved in all of the suturing processes.

The main purpose of this article is to call attention to the IISZ of southeastern Alaska and adjacent areas, with the hope of stimulating detailed studies of it and of comparable globalscale tectonic suture zones. Another purpose is to provide a north-south linkage connecting the areas described in 14 separate and disconnected articles contained in a Geological Society of America Special Paper (Stowell and McClelland, 2000). These articles describe different aspects of the tectonics and geology between Skagway, Alaska, on the north and Bella Coola, British Columbia, on the south. Yet another purpose is to provide a measure of regional and global perspective for those articles.

The global-scale lineament zone (i.e., IISZ) of northwestern North America bounds the Insular superterrane on the west and the Intermontane superterrane on the east (fig. 2). It is one of the main unifying geologic elements in the western Coast Mountains of southeastern Alaska (Brew, 1996b, 1998a, 1998b; Brew and Ford, 1978, 1985b, 1997, 1998). The youngest and most obvious component of the IISZ is the Coast Range megalineament (CRML), which extends from near
Skagway, Alaska, on the north to south of Prince Rupert, British Columbia. As described below, some workers consider the CRML to represent the whole suture zone; this is because several elements in the IISZ are locally coincident with the CRML.

The CRML is an essentially straight fault zone whose youngest movement postdates the dominant 50-Ma granitic rocks of the Coast Mountains. In detail, it is not a continuous fault or lineament, but consists of a combination of straight, en echelon, and bifurcating segments (Brew and Ford, 1978). The lineament is readily recognizable because of Pleistocene/ Holocene erosion. The CRML is wholly within the IISZ and is generally parallel to the strike of the adjacent rocks, has associated aeromagnetic and gravity gradients, and bounds contrasting plutonic and metamorphic belts. Although the strongly linear nature of the CRML suggests a strike-slip origin, no shear-sense indicators or other reliable evidence for lateral movement has been reported for it. To the west of the IISZ are rocks of the Gravina overlap assemblage and the Alexander and Wrangellia terranes; pieces of those units occur in the zone itself, together with rocks of the Nisling and Stikine terranes. East of the IISZ are crystalline rocks of the Wrangellia, Stikine, and Nisling terranes.

A similar global-scale lineament zone (i.e., AESZ) in southern Europe (Clar, 1973; Bögel, 1975; Schmid and others, 1989, 1996; Sprenger, 1996) extends from northwestern Italy into Hungary; it passes through southern Switzerland, northern Italy, southeastern Austria, and northern Slovenia (fig. 3). The zone in Switzerland, Italy, and Austria consists of several connected and en echelon faults that together result in prominent several-kilometer-wide valleys. In Hungary, the zone is concealed by younger Tertiary sedimentary rocks of the Pannonian Basin (Haas and others, 1998; J. Haas, oral commun., 

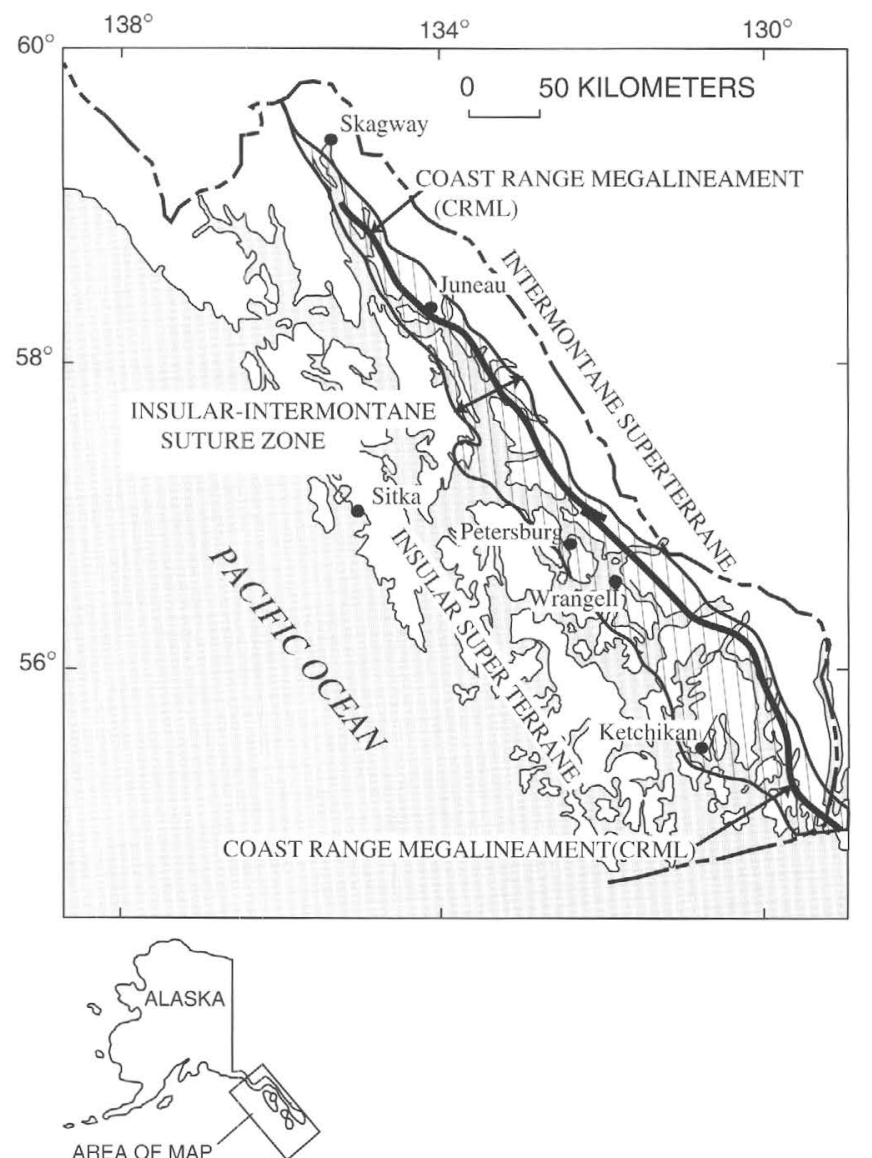

Figure 2. Map showing the Insular-Intermontane superterrane suture zone (IISZ) in southeastern Alaska and adjacent areas. The Coast Range megalineament (CRML) is shown as a single line (modified from Brew and Ford, 1998).

1998). The Periadriatic line (PAL) is the most conspicuous component in the zone. The westernmost part of the PAL is called the Insubric line or lineament; the west-central part, the Guidicarie lineament; the east-central part, the Pustertal lineament; and the easternmost part is called the Balaton lineament or mid-Hungarian line. The PAL, in most places, lies within rocks that originally belonged to the Adriatic superterrane. In general, crystalline rocks of the Austro-Alpine nappes are to the north of the PAL and late Paleozoic, Mesozoic, and Cenozoic rocks of the southern Alps and of the Dolomites are to the south. At depth, the AESZ as a whole is between the European superterrane and the Adriatic superterrane to the south.

Both the IISZ and AESZ have complicated evolutionary histories, and neither is a simple lithotectonic terrane boundary. In both cases, the original contacts of the colliding lithotectonic terranes have been obscured by younger faulting, folding, metamorphic, and magmatic events. In both cases, the zones that record the overall collisional events are much wider and much less obvious than are the prominent lineaments that mark the youngest events. Similarly, although the details and some major aspects of the two zones differ, the plate-tectonic processes that formed them were similar.

\section{Description of the Insular- Intermontane Suture Zone (IISZ)}

\section{General}

The IISZ is a northwest- to southeast-trending zone along the west side of the Coast Mountains in southeastern Alaska and adjacent Yukon and British Columbia (fig. 1). The zone is at least 1,000 km long, of which about $650 \mathrm{~km}$ are in southeastern Alaska. The zone ranges from a few to several tens of kilometers wide and is essentially straight. The Coast Range megalineament (CRML) is the youngest component of the several that define the zone; it is a series of continuous and en echelon topographic lineaments that locally follow discrete faults (Brew and Ford, 1978). The straightness of the CRML immediately brings a strike-slip-fault origin to mind for it and for the IISZ as a whole, but no convincing evidence supports that view for either the CRML or for other features in the zone. All of the kinematic indicators, mainly stretching lineations, associated with older features in the zone point to a dominantly contractional origin, with the northeast side having moved over the southwest on northeast-dipping faults (Hutton and Ingram, 1992; Ingram and Hutton, 1994). Recent assertions of both dextral (Hollister and Andronicos, 1997) and sinistral (Chardon and others, 1998) movement in and (or) adjacent to the zone are based on constructed formlines derived from foliation orientations; they are yet to be tested against the overwhelming shear-sense-indicator evidence for a contractional origin (Hutton and Ingram, 1992; Ingram and Hutton, 1994). Klepeis and others (1998) describe the details of an area in southernmost southeastern Alaska where their interpretation of available kinematic indicators essentially confirms the interpretations of other workers (Hutton and Ingram, 1992; Ingram and Hutton, 1994; Brew and Ford, 1998), albeit ascribing a transpressional origin to the IISZ. Andronicos and others (1999) propose a somewhat different interpretation for the local situation near Prince Rupert, British Columbia. Both of the areas studied by Klepeis and others (1998) and Andronicos and others (1999) lack a stratigraphic unit that is elsewhere critical to the direct interpretation of early parts of the IISZ history, namely the turbidite and associated volcanic rocks of the Early to early Late Cretaceous Gravina overlap assemblage (Brew and Ford, 1998). The Gravina assemblage rocks directly record the collision of the superterranes and bracket the younger magmatism and metamorphism in the IISZ.

The oldest movement in the zone as a whole was at least as old as Late Jurassic (Brew and Ford, 1998) and the youngest movement (on the CRML) postdates the dominant 50-Ma 


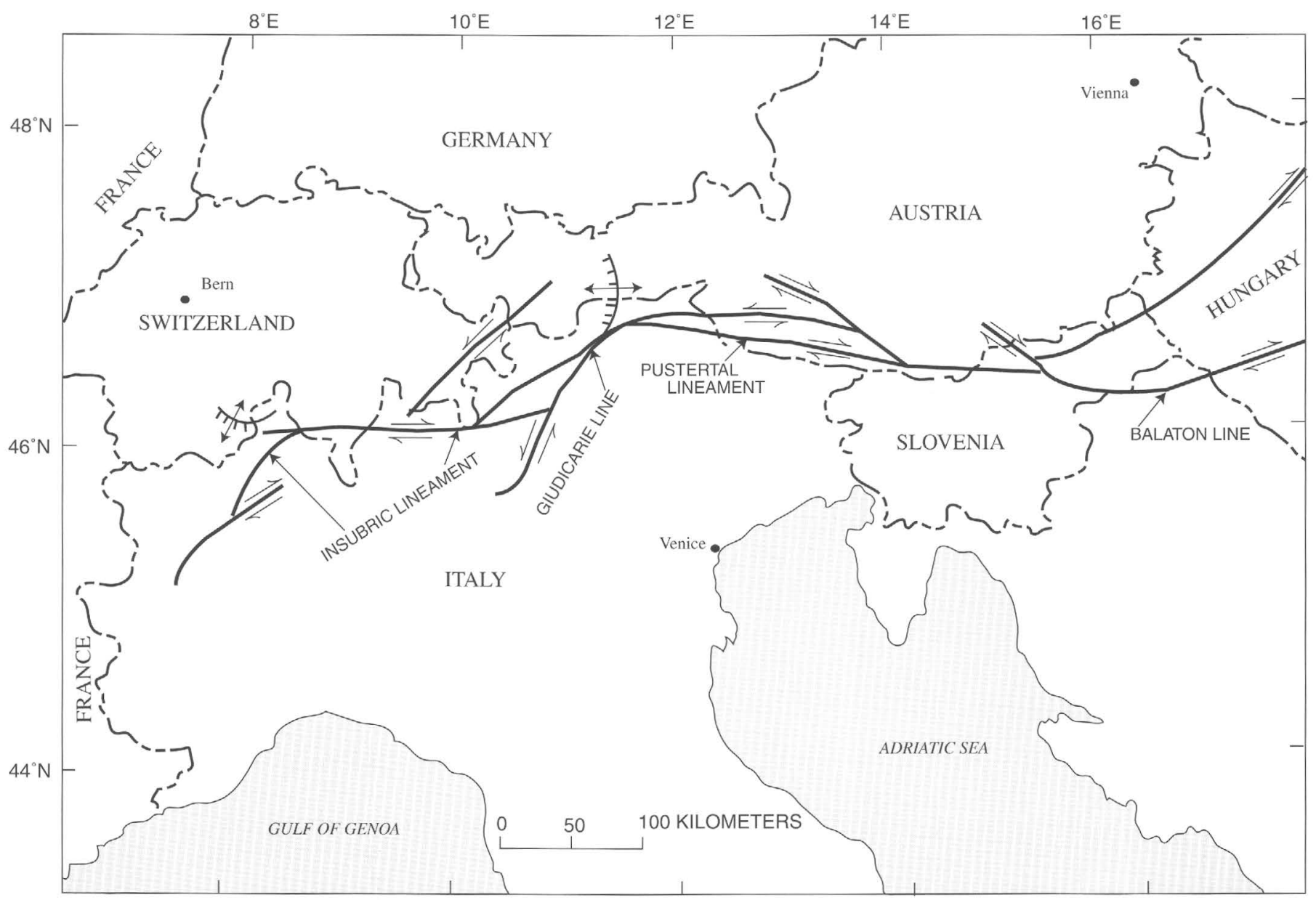

Figure 3. Map showing the Adria-Europe suture zone (AESZ) in southern Europe. The Periadriatic lineament (PAL) is shown as a single line made up of the Insubric, Giudicarie, Pustertal, and Balaton lineaments (modified from Schmid and others, 1989).

granitic rocks of the Coast Mountains. The CRML is more or less parallel to the strike of non-intrusive rock units on either side within the IISZ, and, as noted below, it bounds distinctive intrusive magmatic belts. It also bounds some contrasting metamorphic belts but is within others. The CRML and the IISZ as a whole are also associated with steep aeromagnetic and gravity gradients.

The IISZ records the Cretaceous-age collision between the Insular superterrane/minicontinent to the west and the Intermontane superterrane to the east, together with subsequent related events. There are, all together, five major sequential events involved, each of which generated a specific set of structural features. These features are described by Brew and Ford (1998) and are summarized below. The most conspicuous of these features is the Coast Range megalineament (CRML; Brew and Ford, 1978), but that component of the IISZ represents only the final event, namely the mid- to late Tertiary uplift of the Coast Mountains. The IISZ lies entirely within the southeastern Alaska "coincident zone" described by Brew and Ford (1985b). As pointed out to the author by R.W. Tabor (written commun., 1999), very little of the direct evidence for the initial suturing of the Insular and Intermontane superterranes remains.

\section{Nomenclature}

Before describing the IISZ as the term is used in this article, the reader is alerted to the fact that there are current problems with both the concept and nomenclature for the different structural components of the zone. The situation is complicated because some of the different components in the zone are locally superposed and (or) concordant. As discussed below, most of the confusion stems from various workers accepting "Coast shear zone" as a general term that encompasses all, some, or one of the different structural features that make up the IISZ.

Some examples of uses different than that followed here are: Karl and others (1996) used the term "Coast shear zone" for what is actually the CRML as defined here. Hollister 
and Andronicos (1997), L.S. Hollister (Princeton University, written commun., 1997), and Chardon and others (1998) all attempted to describe the "Coast shear zone," but did not provide a workable set of kinematic, stratigraphic, or lithotectonic criteria that would allow others to replicate their geographic placement of the feature. Rusmore and others (1998) defined the "Coast shear zone" as the zone into which the Great Tonalite Sill composite plutons were emplaced (Hutton and Ingram, 1992; Ingram and Hutton, 1994); they also required that their "Coast shear zone" be the western limit of the uplift of the Coast Mountains. However, the distribution of plutons and the western limit of uplift are not coincident in either southeastern Alaska (Brew, 1994; Brew and Ford, 1998) or in the part of British Columbia (Parrish, 1983) that Rusmore and others (1998) studied.

\section{Lithotectonic Terranes and Magmatic and Other Belts}

The Insular and Intermontane superterranes contain contrasting stratigraphic sequences. The Insular superterrane minicontinent west of the IISZ consists of the Alexander and superjacent Wrangellia terranes of Late Proterozoic to Early Jurassic age, together with the Gravina overlap assemblage of Late Jurassic to Late Cretaceous age. The Alexander terrane consists mainly of sedimentary rocks and some volcanic rocks deposited in a long-lived oceanic-arc system (fig. 4). The superjacent Wrangellia terrane flow and fragmental volcanic and associated abundant sedimentary rocks that rest on the Alexander terrane differ from the "type" Wrangellia terrane flood basalts and carbonates elsewhere in North America. This is because they are interpreted to have erupted through a thin juvenile to transitional continental crust, whereas the "type" Wrangellia volcanic rocks were erupted through oceanic crust. Much of the Insular superterrane has been intruded by granitic and gabbroic rocks of Paleozoic and dominant Mesozoic age. The Gravina overlap assemblage consists of turbidites and volcanic rocks derived largely from a Late Jurassic to early Late Cretaceous arc developed on the Alexander and Wrangellia terrane rocks.

The IISZ itself contains $<1-\mathrm{km}$ - to several-kilometersized terrane fragments from both the Insular and Intermontane superterranes. Alexander terrane, Wrangellia terrane, Gravina overlap assemblage rocks in the zone are derived from the Insular superterrane, and Stikine and Nisling terrane fragments are from the Intermontane superterrane described below.

As the term is used here, the Intermontane superterrane, which is to the east of the IISZ, includes the Late Proterozoic and lower Paleozoic Nisling (also known as Yukon-Tanana) terrane, Paleozoic and Mesozoic Stikine terrane, and the Jurassic and Cretaceous Bowser overlap assemblage. The Nisling terrane consists of locally quartz-rich metasedimentary rocks, metacarbonates, and metavolcanics interpreted to have been deposited adjacent to ancestral North America (fig. 4). The Stikine terrane consists of sedimentary and volcanic rocks of island-arc origin. The original relations between the Stikine and Nisling terranes are uncertain (Brew and others, 1994; Brew and Ford, 1994). The Coast Mountains themselves consist of abundant crystalline rocks metamorphosed from the Stikine and Nisling terranes, together with a few Paleozoic and abundant Cenozoic granitic plutons.

The IISZ both separates and contains distinct and different Mesozoic and Cenozoic magmatic and metamorphic belts. The most striking contrasts are the (1) confinement of the Muir-Chichagof belt of 120- to 110-Ma tonalites and granodiorites to the Insular superterrane, (2) confinement of both the approximately 100- to 90-Ma-old Admiralty-Revillagigedo belt of tonalites and granodiorites and the 125- to 110-Ma Klukwan-Duke belt of Alaska-type mafic-ultramafic bodies to the Gravina overlap assemblage and to the IISZ itself, (3) the confinement of the 55- to 70-Ma Great Tonalite Sill belt of tonalites to within the IISZ, and (4) the restriction of the voluminous 55- to 50-Ma granodiorites and granites of the Coast Mountains to the Intermontane superterrane. (The plutonic belt names used here are modified from those of Brew and Morrell 1980a, 1980b, 1983 and Brew, 1994).)

Less striking differences are also apparent in the distribution of the several major metamorphic belts present on the different sides of the IISZ (Brew and others, 1992). More important is the coincidence of the major Late CretaceousPaleocene Barrovian belt with the IISZ; this belt, together with the Great Tonalite Sill magmatic belt that runs through the region parallel to the CRML (fig. 2), obscured much of the evidence of some of the earlier events in the IISZ.

The IISZ is more-or-less coincident with both steep magnetic and gravity gradients (Brew and Ford, 1978; Jachens, 1984; Barnes, 1984; Brew and others, 1995; R.L. Morin, U.S, Geological Survey, oral commun., 1998; Saltus and others, 1999). A series of en echelon aeromagnetic highs lies under and adjacent to the eastern part of the zone, reaching values of about 300 nanoteslas. The highs are more continuous and closely aligned with the IISZ in southern southeastern Alaska than in the north, where the highs are more discontinuous. Isostatic gravity highs are also discontinuous along the IISZ, and in northern southeastern Alaska the values decrease abruptly eastward across the zone from +20 to about -50 milligals. In northern southeastern Alaska, the highs are coincident with the zone, but in southern southeastern Alaska, they trend more north-south and are located several tens of kilometers west of the IISZ. The IISZ is essentially aseismic throughout its length, but some offset of glacial deposits suggests west-sidedown post-glacial faulting.

\section{Evolution of the Suture Zone}

Brew and Ford (1998) described the history of tectonic, magmatic, and metamorphic events in the IISZ and related them to the five closely spaced structural zones that make up 


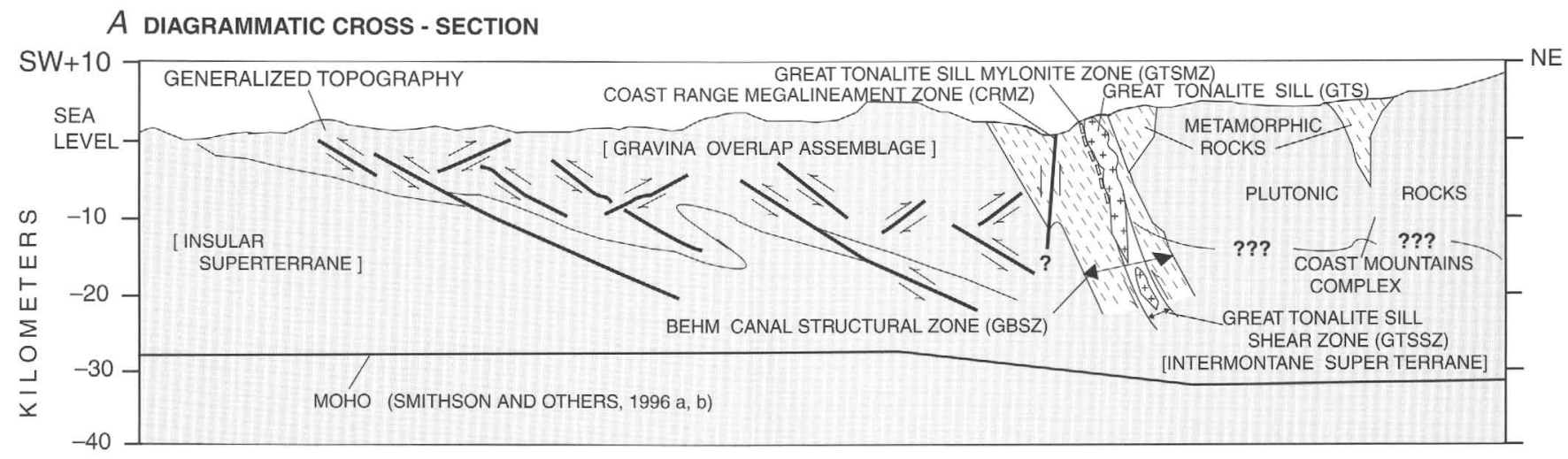

B AGE AND DISTRIBUTION OF STRUCTURAL ZONES

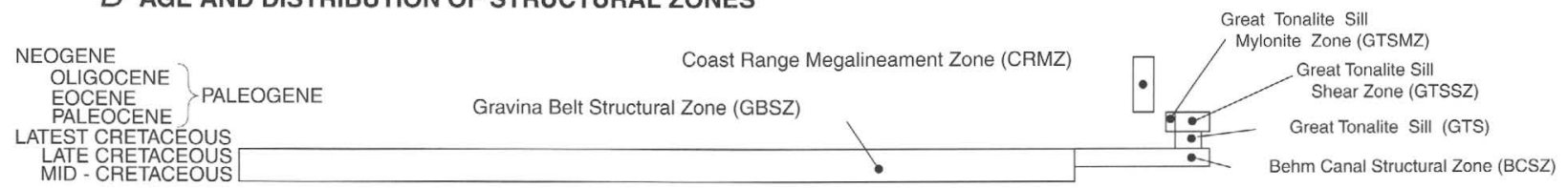

\section{AGE AND DISTRIBUTION OF PLUTONIC BELTS}

$50 \mathrm{Ma}$

U⿺
岁 $69-50 \mathrm{Ma}-55 \mathrm{Ma}$

$100-90 \mathrm{Ma}$

\section{$D$ LITHOTECTONIC TERRANES}

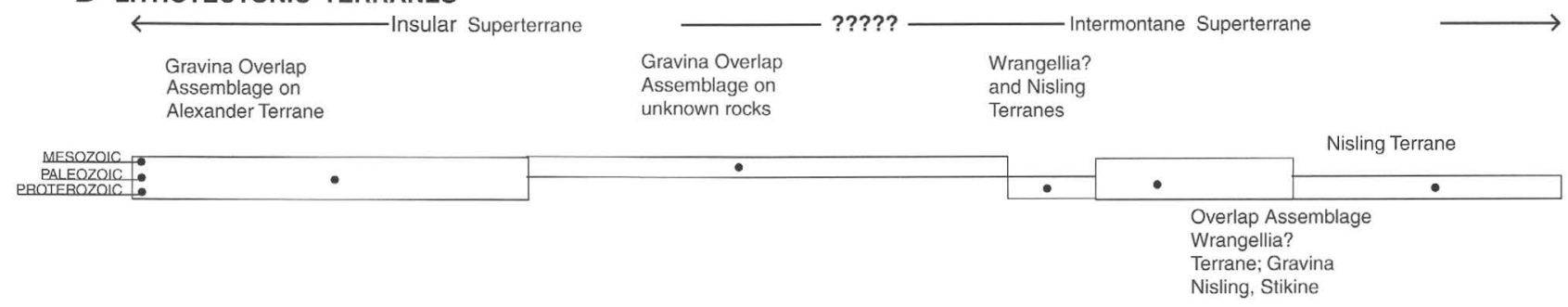

Figure 4. Diagrammatic sections depicting present-day relations of the five structural zones of the Insular-Intermontane superterrane suture zone (IISZ) and related plutonic bodies (after Brew and Ford, 1998). A, Diagrammatic cross section. Limits of bracketed units are uncertain; arrows show relative movement on faults; question marks indicate uncertainty; queried line below "Plutonic Rocks" indicates base of granitic part of Coast Mountains Complex. B, Age and distribution of structural zones. $C$, Age and distribution of plutonic belts. $D$, Age and distribution of lithotectonic terranes.

the IISZ. From oldest to youngest, the structural zones are the (1) Gravina belt structural zone of mid- to Late Cretaceous age that shortened and thickened Lower to Upper Cretaceous sedimentary, volcanic, and conglomeratic rocks of the Gravina overlap assemblage; (2) Behm Canal structural zone of latest Cretaceous age in which rocks of the Gravina overlap assemblage are juxtaposed with rocks of the Alexander and Wrangellia terranes of the Insular superterrane and with rocks of the Nisling terrane (Yukon-Tanana terrane equivalent) of the Intermontane superterrane; (3) Great Tonalite Sill (GTS) shear zone of latest Cretaceous and Paleocene age that controlled the emplacement of the GTS plutons within the Behm Canal structural zone, mostly between about 85 and $56 \mathrm{Ma}$; (4) Great Tonalite Sill mylonite zone of Paleocene and Eocene age that indicates near-vertical sub-solidus movements in a narrow zone along the footwall of the GTS during and after the sill's emplacement; and (5) Coast Range megalineament zone of inferred Eocene to Holocene age, which was the major western boundary of Coast Mountains uplift. Figure 4 depicts the present relations of the five structural zones, and figure 5 is a diagrammatic interpretation of the evolution of the structural zones and, hence, of the IISZ. Perhaps the most important feature to be noted in figure 5 is the hypothetical history of changes in position and continuity of the original Insular- 
Intermontane superterrane boundary in space and time, leading to the near impossibility of identifying it uniquely in today's outcrops.

\section{Description of the Adria-Europe Suture Zone (AESZ)}

\section{General}

The Adria-Europe suture zone (AESZ ) is a more or less west- to east-trending zone of topographic lineaments and faults between the southern Alps and the Dolomites on the south and the northern edge of the Austro-Alpine and Pennine nappes. These lineaments and faults are mainly in a series of interconnected valleys in western and northern Italy, southernmost Switzerland, and Slovenia (fig. 3). The westernmost part of the zone, in northwestern Italy, is oriented southwest-northeast; going eastward, it turns to a general east-west orientation in southernmost Switzerland and northcentral Italy. The northeast-southwest-trending Giudicarie line is a left-lateral strike-slip segment of the AESZ that connects the Insubric and Pustertal lineaments (fig. 2). According to Selverstone (1988), the Giudicarie line appears to be related to the tectonic denudation of the western end of the Tauern window in Austria to the north. However, according to Fügenschuh and others (1997), there is no tectonic or geographic connection between the two. The AESZ is at least $800 \mathrm{~km}$ long and may be as much as $300 \mathrm{~km}$ longer to the east underneath the late Tertiary cover of the Pannonian Basin in Hungary (Hippolyte and others, 1999). It is from five to a few hundreds of kilometers wide; the individual lineaments that make up the prominent Periadriatic lineament (PAL) are defined by a narrow set of splayed and joined faults. In the broadest sense, the width of the zone is actually defined by the rocks in the nappes that extend several tens to hundreds of kilometers north of the zone that originally belonged to the Adriatic superterrane. However, by defining the AESZ as the place where multiple tectonic events occurred, only part of the northern Alps are included, and the AESZ is several tens of kilometers wide. Although highly variable, the AESZ and the PAL are more or less parallel to the strike of rock units on either side; the PAL bounds contrasting metamorphic belts and has a belt of relatively small and discontinuous intrusions along it (Davidson and others, 1996). Another characteristic is the abundance of associated ophioitic bodies. In the west, in particular, the zone has associated steep geophysical gradients (Schmid and others, 1989; Wybraniec and others, 1998). The western end is complicated by its direct association with the Ivrea zone (the western part of the Insubric lineament, fig. 3 ), where mantle and lower crustal rocks are exposed at the surface (Quick and Sinigoi, 1992; Quick and others, 1994; Quick, 1998; Handy and others, 1999).

The AESZ records the Late Cretaceous- and Tertiary-age collision of the Adriatic superterrane with the European superterrane to the north, as well as subsequent related events. For convenience, the term "Adriatic superterrane" is used here for the rocks of southern origin; the term thus includes the African continent, African and European continental-margin rocks, and any possible minicontinental fragments that existed in the Piedmont Ocean separating the two continental plates of proto-Africa and proto-Europe (Bosellini, 1996; Avigad and others, 1993). Different parts of the AESZ have different histories, but in general the record includes (1) original northward thrusting of the Piedmont Ocean rocks and African plate rocks over the preexisting European basement to the north, (2) metamorphism of some of the overthrust rocks, (4a) southwardvergent back thrusting in the western part of the zone, (3) intrusion of tonalitic and other magmas discontinuously along the zone (Davidson and others, 1996), (4b) northward-vergent thrusting in the eastern part, (5) back-thrusting at various places, (6) contractional followed by left-lateral strike-slip movement along the Giudicarie line segment of the AESZ, and (7) uplift near the center-longitudinal part of the zone and the development of the lineaments that are obvious today. The most conspicuous of these features are the lineaments; they are called the Insubric line or lineament in the west in Italy and Switzerland, and the Pustertal line or lineament in northern Italy and southern Austria (fig. 3). Schmid and others (1989) mapped the Insubric lineament as several short connected segments, suggesting that that may be a common style for the Periadriatic lineament. The most comprehensive descriptions of the AESZ are given by Bögel (1975), Schmid and others (1989), and Sprenger (1996); the last two sources concentrate on the western and the eastern exposures of the AESZ, respectively. As pointed out to the author by R.W. Tabor (U.S. Geological Survey, written commun., 1999), much of the direct evidence for the initial suturing of the Adriatic and European superterranes is still present.

\section{Stratigraphic Sections and Geophysical Belts}

The Adriatic and the European superterranes contain different stratigraphic sequences. The Adriatic superterrane has a relatively thin crust and its interoceanic-arc rocks range in age from Ordovician to Cretaceous. The clearest differences are present on opposite sides of the Pustertal lineament; to the south is a thin section of Paleozoic sedimentary and volcanic rocks overlain by the thick spectacular Mesozoic carbonates and shales of the Dolomite Mountains of the southern Alps. Those rocks are, in general, less deformed than are those in the areas immediately north of the lineament; the rocks to the north are mainly metamorphosed pelitic and volcanic rocks that are now part of the Austro-Alpine crystalline nappe package, even though most of them originally were part of the Adriatic superterrane. In this same area, the PAL is clearly the result of only the last movements in the collision zone (Bosellini, 1996), and the original collision boundary is now fragmented and modified by later faulting, intrusion, and 


\section{EARLY LATE CRETACEOUS}

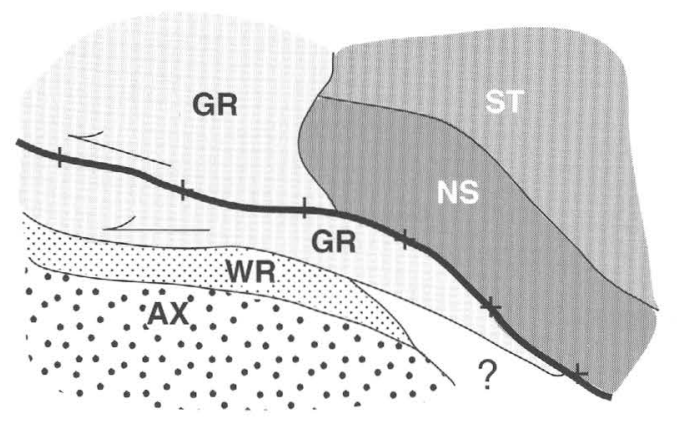

LATEST CRETACEOUS

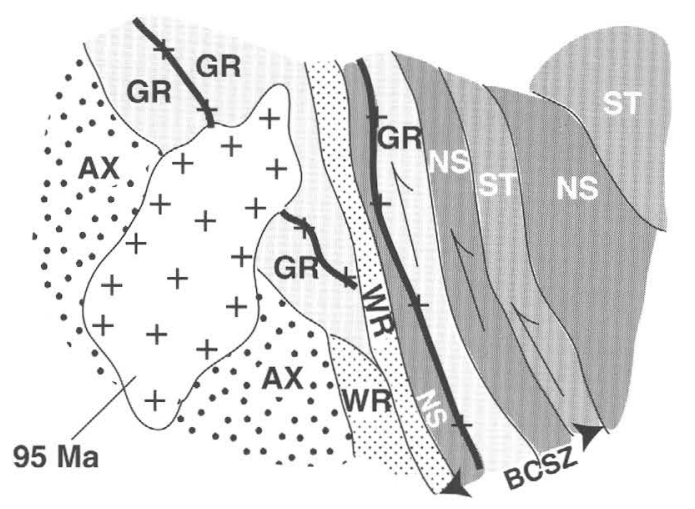

EOCENE

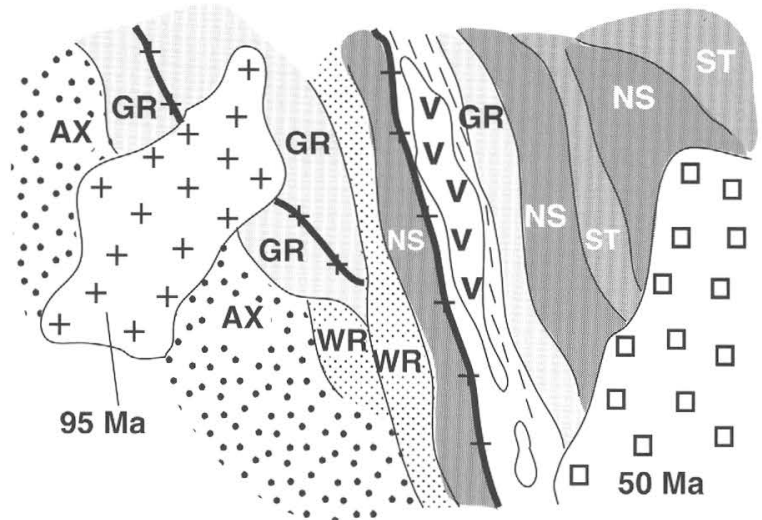

LATE CRETACEOUS

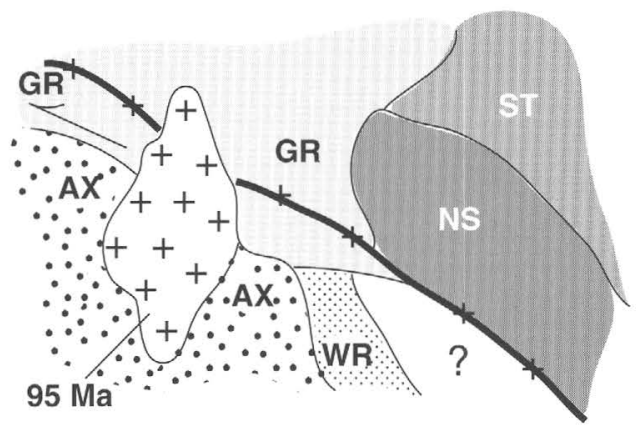

\section{PALEOCENE}

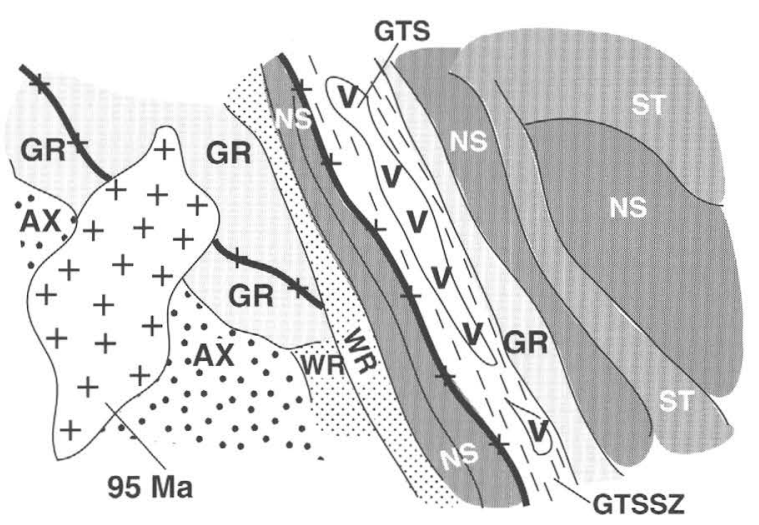

$95 \mathrm{Ma}$

Figure 5. Diagrammatic sections showing the evolution of the IISZ in southeastern Alaska and adjacent areas; line with "+'s" represents the original Insular-Intermontane superterrane boundary. AX, Alexander terrane; BCSZ, Behm Canal structural zone; CRML, Coast Range megalineament; GR, Gravina overlap assemblage; GTS, Great Tonalite Sill; GTSMZ, Great Tonalite Sill mylonite zone; GTSSZ, Great Tonalite Sill shear zone; NS, Nisling terrane; ST, Stikine terrane; WR, Wrangellia terrane; ?, Oceanic crust(?). 
metamorphism. C.M. Davidson (written commun., 2000) has pointed out the almost ubiquitous presence of ophiolitic bodies in the AESZ, in part very close to the PAL.

Geophysically, the western part of the AESZ is associated with discontinuous, strong gravity anomalies that more or less parallel the zone (Schmid and others, 1989) and are close to it. The recently compiled gravity map of Europe (Wybraniec and others, 1998) shows a strong arcuate negative Bouguer anomaly associated with the western end of the AESZ. To the east, Sprenger (1996) makes the point that a similar belt of anomalies lies appreciably to the north of the AESZ and ascribes the divergence to transpression or to irregular subsurface forms of the colliding plates. There apparently is no distinct seismicity associated with the AESZ (Simkin and others, 1994; Bosellini, 1996), but Sprenger (1996) relates one recent event (described below) to the zone.

\section{Evolution of the Suture Zone}

Most evidence (Schmid and others, 1989, 1996) indicates that the earlier Cenozoic movements affecting the two superterranes was contractional, with the Adriatic superterrane having overriden the European superterrane; in the western part of the AESZ the movements were northwest vergent; those in the eastern part were north vergent. This difference, plus the effects of later uplift and extension in the AustroAlpine rocks north of the zone probably explain the existence of several strike-slip faults in the central part of the AESZ (fig. 3) and the dominance of strike-slip movement in the late Tertiary. The south-vergent contractional faulting discussed below is younger than the main collision event; it is essentially large-scale back-thrusting, although it was interpreted by Clar (1973) as representing a fundamental difference in vergence of the collisional system.

The evolution of the Adria-Europe suture zone varied from west to east. In the west, near the bend in the zone (fig. 3), Schmid and others (1989) described a complicated sequence of events. (1) It starts with pre-Oligocene northwestward-directed thrusting of the tonalite and mafic rocks of the Ivrea zone; the mylonite zone developed in the ecologitic and crystalline rocks of the Sesia zone originally north of the superterrane boundary. (2) Those events were followed by Oligocene extension, erosion, magmatism, and sedimentation across the boundary. (3) Those events were followed by post-Oligocene thrusting of the same sense as the original collision. (4) Uplift and south-inclined rotation of the area to the north preceded further uplift, back thrusting of opposite sense, continued rotation, and strike-slip faulting. (5) Intrusion of granite and tonalite along the back-thrust zone preceded the development of associated mylonite units close to what is now called the Insubric lineament. These events are summarized schematically in figure 6. Schmid and others (1989) argue that most of these events occurred in a semicontinuous transpressive dextral strike-slip environment. The Sesia zone rocks noted above, and the Schistes Lustres unit still farther north, are interpreted by Avigad and others (1993) to have been part of the Adriatic plate to the south. Thus here, as in other localities, the conspicuous expression of the AESZ (the Insubric lineament) is tens of kilometers to the south of the true northern margin of the AESZ.

In the central part of the AESZ, in the vicinity of the Dolomites, Bosellini (1996) described a sequence of events that started with the Cretaceous-age southward subduction of the European plate beneath the African plate. The European plate had some oceanic crust and some marginal oceanic sediments attached to it; the African plate had its leading orogenic wedge attached to it as well as some oceanic sediments. The subduction was followed by continuing Eocene to Oligocene movements of the same sense-those movements resulted in the main Alpine folding events. Caught up in the folding were ophiolitic bodies that were associated with the oceanic crust, oceanic sediments, and with the orogenic wedge. This was accompanied by both some small-scale south-vergent backthrusting. Finally, during Miocene to Holocene time erosion exhumed the northern Alps, and the Pustertal lineament was eroded between the uplifted northern and southern Alps (the Dolomites). These events are summarized schematically in figure 7. Bosellini does not describe large-scale rotations like those noted above as present in northwestern Italy, and he argues that the northern Alps are dominated by northvergent structures and the southern Alps by south-vergent ones. Bosellini argues that all of these events occurred in a contractional environment and that strike-slip movements were rare.

\section{Comparison of the IISZ and AESZ}

The IISZ and the AESZ are similar in many aspects but also differ in some. Table 1 describes features common to the two zones; it is apparent that the main differences are (1) age of movement, (2) geographic linearity/non-linearity, (3) width of the suture zones, (4) volume of associated plutonic rocks, (5) ophiolitic bodies in the AESZ but not in the IISZ, (6) distribution of geophysical anomalies, (7) sense of movement, and (8) degree of development. These eight topics are discussed here, with speculations as to why the differences exist.

The difference in age of movement - with the IISZ having been active from Early Cretaceous (and perhaps earlier) through Late Tertiary and perhaps into the Holocene and the AESZ having been active from Late Cretaceous through middle Tertiary and also perhaps into the Holocene-is due to differences in age of the large-scale tectonic plate movements that led to the formation of the zones. This is by itself trivial. However, the difference is significant because the IISZ developed during a relatively long period, from perhaps as old as Late Jurassic to the Quaternary, whereas the AESZ has developed to its present configuration between the Tertiary and Quaternary. Although the features in the two zones were initiated at different times, 
1. pre-Oligocene thrusting along mylonite belt 1

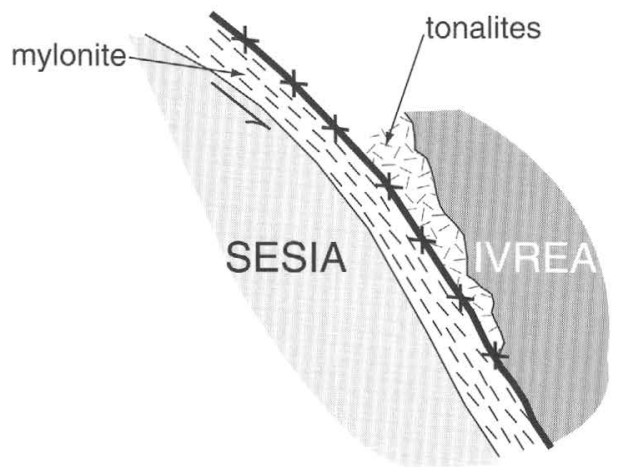

3. post - Oligocene thrusting

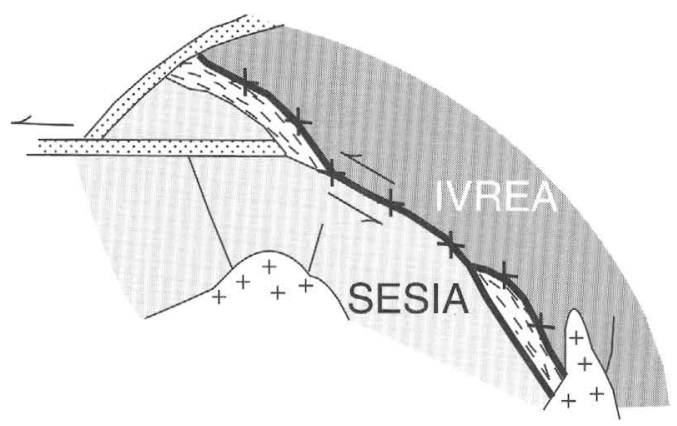

5. futher uplift and back thrusting (belt 2) $60^{\circ}$ rotation

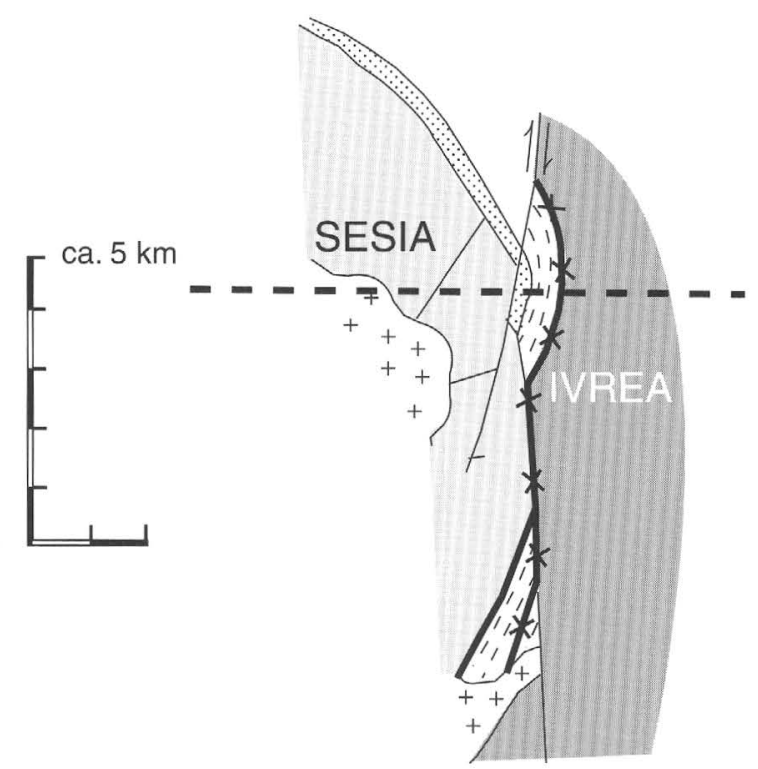

2. Oligocene extension, erosion, magmatism and sedimention

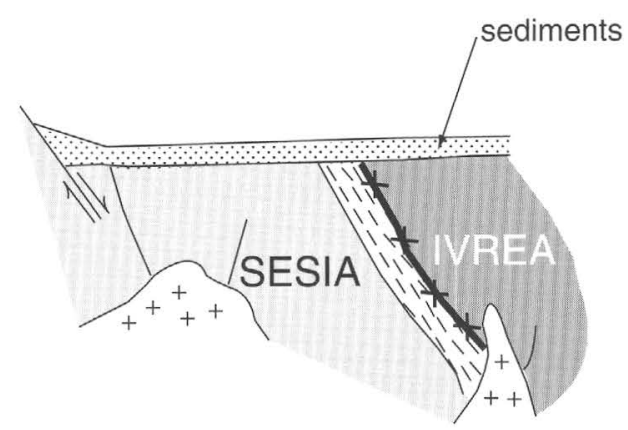

4. differential uplift of Sesia unit $30^{\circ}$ rotation

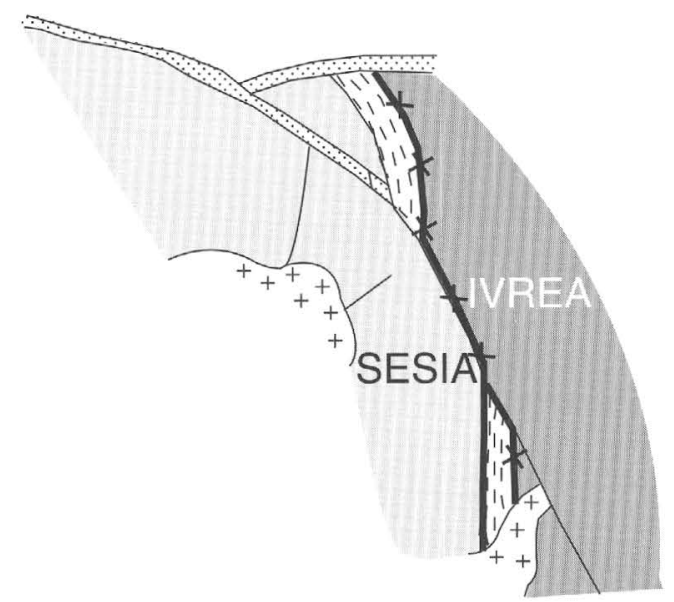

6. schematic present-day section

mylonites of

belt 1 (pre - Oligocene)

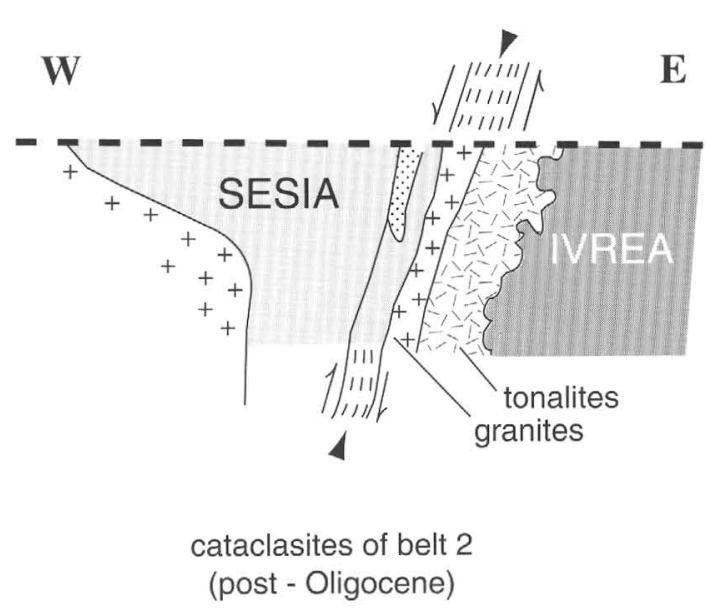

Figure 6. Diagrammatic sections showing the evolution of the Adria-Europe suture zone (AESZ) at its western end where it coincides with the segment of the PAL called the Insubric lineament (modified from Schmid and others, 1989); in all diagrams, the line with " $x$ 's" represents the original Adriatic-European superterrane boundary; dashed line in diagrams 5 and 6 is present erosion surface. 


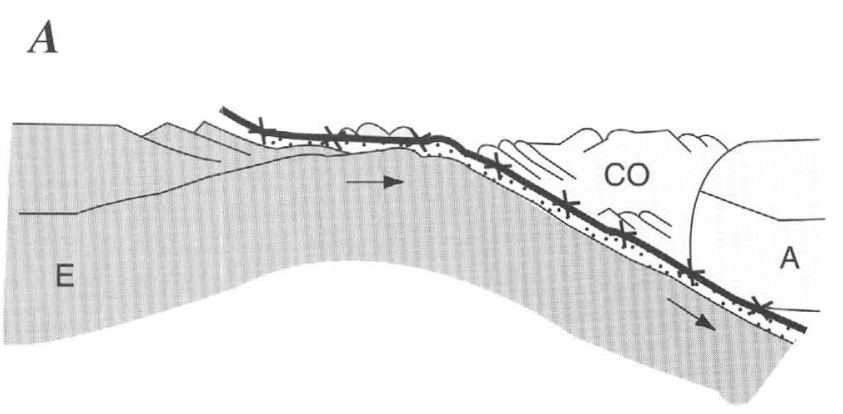

$\boldsymbol{B}$

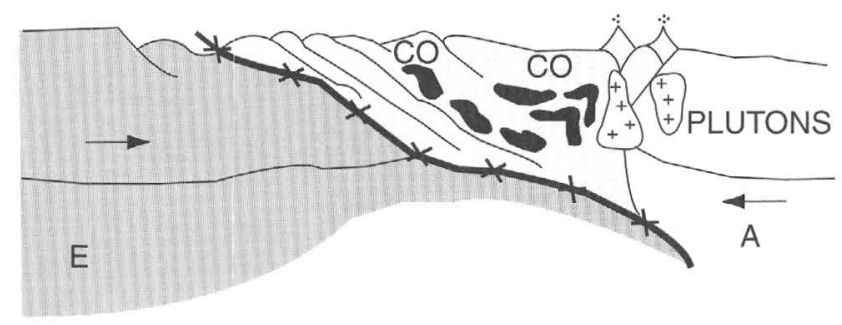

C

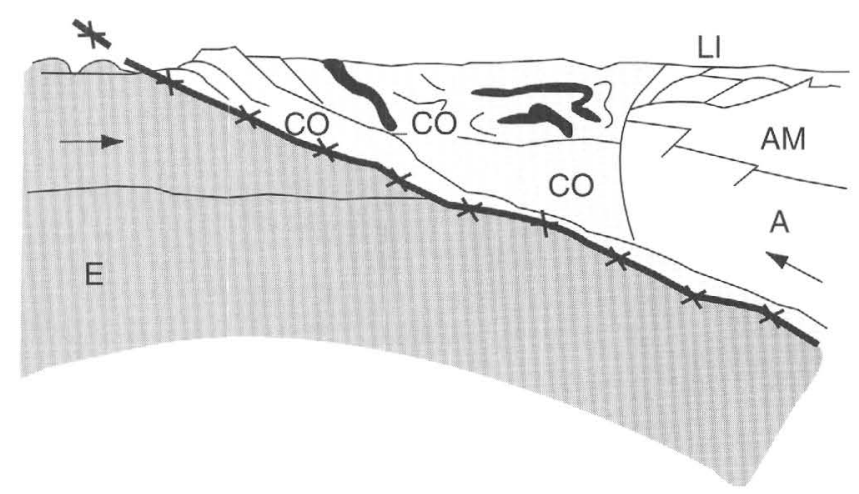

Figure 7. Diagrammatic sections showing the evolution of the AdriaEurope suture zone (AESZ) across its whole width in northern Italy, where it is called the Pustertal lineament and is between the Dolomites to the south and the Austro-Alpine crystalline nappes to the north (modified from Bosellini, 1994); Events: $A$, Latest Cretaceous; $B$, Eocene-Oligocene; $C$, Miocene-Holocene; in all diagrams, the line with " $x$ 's" represents the original Adria-Europe superterrane boundary. Heavy black line and black units represent oceanic crust of the Piedmont Ocean, which were tectonically mixed with the orogenic wedge deposits during Alpine thrusting in the Eocene-Oligocene, thus parts of the original superterrane boundary are also in the Alps, but are not marked with $x$ 's in this diagram; E, European plate; $A$, African plate; CO, orogenic wedge; LI, Pustertal lineament.

the general path of evolution is similar, from continental-scale overthrusting to vertical movements in a final narrow lineament subzone within the whole zone. It appears that the IISZ is currently completely aseismic, whereas parts of the AESZ are interpreted by Sprenger (1996) to be currently active.

The IISZ is strikingly linear as shown by its youngest component, the Coast Range megalineament (CRML, fig. 2), although it has some minor changes in trend. In contrast, the AESZ consists of a series of segments of significantly different orientation as shown by the Periadriatic lineament (PAL, fig. 3) itself. This difference may relate to the different ages of the two zones, with the IISZ having undergone a longer duration of deformational events that effectively straightened and narrowed what was an originally more irregular and broader course. There is a conundrum here inasmuch as the less linear AESZ records significant transpressional and strike-slip movements and the more linear IISZ apparently records mainly contractional movement. One hypothesis to explain the conundrum is that (1) the contractional record of the IISZ is contained mainly in mesoscopic features of the Great Tonalite Sill; (2) the contractional event preceded strike-slip movements whose evidence is yet to be found; (3) such evidence might be found in the microfabrics that developed in mylonites present in the footwall of the GTS, in tectonites in the metamorphic units, and in mylonites that are part of the younger CRML (Klepeis and others, 1998). Another hypothesis to explain the conundrum is that strike-slip movements preceded the contractional events that are recorded in the GTS.

There is a marked difference between the IISZ and the AESZ in the volume of associated plutonic rocks. As pointed out by Brew and Ford (1985), several different plutonic belts with different ages and compositions are located within and adjacent to the IISZ. The largest of these is the almostcontinuous Great Tonalite Sill belt. In contrast, the AESZ is marked by relatively small and widely distributed plutons of mostly Tertiary age. It has been suggested (C.M. Davidson, written commun., 2000) that the reason is that the ocean separating Europe and Africa was small and subduction-zone melting of the mantle wedge never became well established.

The IISZ has no associated ophiolite bodies, whereas the AESZ has many distributed throughout its length. It appears that the IISZ is an anomaly amongst the Earth's large suture zones in this respect. There seems to be no obvious explanation for this unusual situation. A belt of dismembered, metamorphosed, and deformed ophiolitic bodies is present within the Nisling terrane rocks in the Coast Mountains (D.A. Brew, unpub. data; R.A. Loney, written commun., 2000), but it is not associated with the IISZ.

The difference in the distribution of geophysical anomalies is perhaps more apparent than real. In the IISZ, the linear anomalies closely follow the zone along its northern part and are located to the west of the zone in the southern part. The displacement is into the substrate of the subducted Insular superterrane. In the AESZ, the linear anomalies follow the zone in its western part and are located to the north of the zone in the eastern part. The displacement here is into the substrate of the subducted European plate. The divergence associated with the IISZ may also be caused by transpression or by irregular forms of the colliding plates. The geophysical 


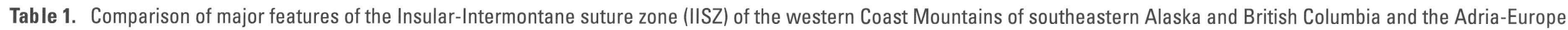
suture zone (AESZ) of southern Europe.

\begin{tabular}{lc}
\hline \multicolumn{1}{c}{ Feature } & \multicolumn{1}{c}{ Insular-Intermontane suture zone (IISZ) } \\
\hline $\begin{array}{l}\text { Name of obvious } \\
\text { lineament(s) }\end{array}$ & Coast Range megalineament (CRML) \\
Subducted plate & Insular superterrane (Alexander terrane with stratigraphically overlying \\
Wrangellia terrane rocks) of Late Proterozoic to Middle Jurassic age \\
Overlying plate \\
Intermontane superterrane (Nisling (Yukon-Tanana) terrane with \\
associated Stikine terrane rocks) of Late Proterozoic to Jurassic age \\
Between-plate units \\
On east margin of Insular superterrane: Gravina overlap assemblage- \\
Turbidites and volcanics of Late Jurassic to middle Cretaceous age
\end{tabular}

Length $\quad 1,000$ kilometers

\section{Width}

Orientation

Geographic linearity/nonlinearity

Consistency of vergence

Associated magmatic belts

Associated metamorphic belts

Age of movement

\section{Less than one to tens of kilometers; narrow}

Northwest-southeast

Linear with few inflexion points and no contrasting segments; narrow

Main movements were unidirectional from northeast to southwest Periadriatic line (PAL), composed of Insubric (including Cremosina,
Canavese, Tonale), Giudicarie, and Pustertal (including Gailtal, caused north to south vergence

Admiralty-Revillagigedo tonalite and granodiorite belt from the 55- to 50-Ma Coast Mountains granodiorite and granite belt

Contains the inverted Barrovian Western Metamorphic Belt (Brew and others, 1989) of the Coast Mountains Complex (Brew and others, 1994), as well as contact-metamorphic belts associated with the abovementioned plutonic belts

Northeastward subduction of Gravina overlap assemblage rocks started in Late Jurassic or Early Cretaceous; other events continued at least until Neogene and probably Holocene
Defereggen-Anteselva-Vals, Mölltal) lineaments; also Balaton line

European superterrane of early Paleozoic to Mesozoic age

Adria/African superterrane of Paleozoic to Mesozoic age

North-to-south: European-plate marginal-clastic units of Mesozoic age, Piedmont Ocean clastic and carbonate units (Adria minicontinent) of late Paleozoic to Cretaceous age, African-plate marginal-clastic units of Mesozoic age

800 kilometers, and perhaps 1,100 with the continuation beneath the Pannonian Basin in Hungary

A few (5) to many tens of kilometers; narrow to broad

From west to east: southwest-northeast, east-west, southwest-northeast, east-west

Distinctly non-linear, with connected segments of different orientation

Main movements were polydirectional, from south to north in the eastern part of the zone and southeast to northwest in the western part; important dextral strike slip; back-thrusting in the eastern part has

Contains discontinuous bodies of Neogene tonalite and granodiorite in the west and Paleogene-Neogene bodies in the east; the concealed Balaton line may be paralled by a continuous tonalite unit

Generally separates higher grade metamorphic rocks (greenschist, amphibolite, and higher pressure facies) on the north from lower grade rock facies to the south

Generally northward obduction of the Piedmont Ocean minicontinent(s) and the African plate started in Late Cretaceous; other events continued at least until Neogene and probably Holocene 
information for both suture zones is relatively old and sparse. The difference in the sense of dominant movement on the IISZ and the AESZ has been discussed briefly above. Both zones record major early orthogonal or near-orthogonal superterrane collisions; the thrusts and the gross distribution of rocks derived from the two plates in both zones demonstrate kilometers of closure. The AESZ contains both macroscopic and microscopic evidence for strike-slip and transpressive movements superposed on the zone following (and perhaps accompanying) that collision. The IISZ has yet to yield convincing evidence for strike-slip or significant transpression, even though the history of outboard Pacific plate movements (Debiche and others, 1987; Engebretson and others, 1985) suggests that such movements were extremely likely.

\section{Conclusions}

There are two sets of conclusions from this study of global-scale tectonic sutures; the first set pertains to the specifics of these two suture zones and the second pertains to larger concepts. Taken together, the conclusions indicate that many of these large-scale structural features may have very similar evolutionary histories and involve essentially the same processes, regardless of the age of the zones or the ages of the rocks involved.

\section{Specific Conclusions}

1. The global-scale Insular-Intermontane suture zone (IISZ) is between the Insular superterrane to the west and the Intermontane superterrane to the east in the western part of the Coast Mountains of southeastern Alaska and British Columbia; it records the Cretaceous through Tertiary collision of the superterranes. The youngest and most obvious component of the zone is the Coast Range megalineament (CRML). The global-scale Adria-Europe suture zone (AESZ) of southern Europe records the Tertiary collision of Adria to the south with the European superterrane to the north. The Periadriatic lineament (PAL) is the youngest and most obvious component of the AESZ. Both of these suture zones are the products of similar processes and have complicated evolutionary histories. Neither is a simple lithotectonic terrane boundary; in both cases, the original lithotectonic terrane contact, or boundary, has been obscured by younger faulting, folding, metamorphic, and magmatic events.

2. The IISZ is the main unifying geologic element of the western Coast Mountains of southeastern Alaska and adjacent British Columbia. The IISZ consists of five inpart-superimposed shear zones (Brew and Ford, 1996, 1998); the whole IISZ is as much as $50 \mathrm{~km}$ wide. As noted above, the youngest and most obvious of the 
five shear zones is the crustal-scale geomorphic and structural component described as the Coast Range megalineament (CRML). The CRML is a $800-\mathrm{km}$-long, $<1-\mathrm{km}$ - to a several-tens-of-kilometers-wide, NNW.SSE.-trending, essentially straight fault zone whose youngest movement postdates the dominant 50-Ma granitic rocks of the Coast Mountains. It is readily recognizable because of Pleistocene/ Holocene erosion. The CRML and the IISZ as a whole are parallel to the strike of the adjacent rocks and have associated aeromagnetic and gravity gradients. To the west of the IISZ are rocks of the Gravina overlap assemblage and the Alexander and Wrangellia terranes; pieces of those units occur in the zone itself together with rocks of the Nisling and Stikine terranes. East of the zone are crystalline rocks of the Wrangellia, Stikine, and Nisling terranes. The strongly linear nature of the IISZ suggests a strike-slip origin, but no shear-sense indicators or other reliable evidence for lateral movement has been reported for it.

3. The AESZ consists of several separate structural elements that occur in different parts of southern Europe; the youngest and most obvious of these is the crustalscale geomorphic and structural component called the Periadriatic lineament (PAL). The PAL is the final expression of the series of tectonic, metamorphic, and intrusive events that occurred near and along the contact between the European superterrane to the north and the Adriatic superterrane to the south during the Cenozoic. Those events include both N.- and S.-directed contractional and E.-W. strike-slip faulting. The AESZ is at least $800 \mathrm{~km}$ long and varies from a NE.-SW. orientation to the west to E.-W. on the east. The zone in Switzerland, Italy, and Austria consists of several connected and overlapping faults that together result in prominent several-kilometer-wide valleys. The PAL is parallel to the strike of the adjacent rocks, bounds contrasting plutonic and metamorphic belts, and has associated geophysical gradients. In general, crystalline rocks of the Austro-Alpine nappes form the northern part of the AESZ; late Paleozoic, Mesozoic, and Cenozoic rocks of the southern Alps and of the Dolomites are to the south, but many of the rocks on both sides of the PAL are part of the Adriatic superterrane.

\section{Larger Scale Conclusions}

1. The conspicuous lineaments associated with both the IISZ and the AESZ are the final and most conspicuous manifestations of the complicated series of superterrane collisional events and are not themselves the boundaries between the superterranes; because of this it is considered likely that other major lineaments are also only a relatively recent component in their collisional histories.
2. Global-scale tectonic suture zones such as these are likely to be at least several kilometers wide and characterized by (a) thrust imbrication of rocks from both sides of the suture, (b) associated elongate geophysical anomalies that approximately parallel the zones, and (c) local mylonite zones.

3 . Studies of mesoscopic shear-sense indicators and mapunit relations may not suffice to unravel the strike-slip, transpressional, and contractional movement history of a zone; microfabric studies of the tectonites and mylonites may be required.

4. Suture zones and their lineaments separate magmatic and geophysical belts; this indicates that deep-crustal and perhaps sub-crustal structures exist that are not directly mirrored in the upper-crustal rocks. Similarly, the presence of abundant and commonly elongated tonalitic plutons within the zones may indicate deepcrustal structures.

\section{References Cited}

Andronicos, C.L., Hollister, L.S., Davidson, C., and Chardon, D., 1999, Kinematics and tectonic significance of transpressive structures within the Coast Plutonic Complex, British Columbia: Journal of Structural Geology, v. 21, p. 229-243.

Avigad, D., Chopin, C., Goffé, B., and Michard, A., 1993, Tectonic model for the evolution of the western Alps: Geology, v. 21, p. 659-662.

Barnes, D.F., 1984, Interpretation of the available gravity data, in Mineral Resources of the Tracy Arm-Fords Terror Wilderness Study Area and Vicinity, Alaska: U.S. Geological Survey Bulletin 1525, p. $63-72$.

Bögel, H., 1975, Zur Literatur über die "Periadriatische Naht:" Verhandlungen Geologische Bundesanstalt 1975, v. 2-3, p. 163-199

Bosellini, A., 1996, Geologia delle Dolomiti: Bolzano-Bozen, Italia, Casa Editrice Athesia, 192 p. [ISBN 88-7014-889-0].

Brew, D.A., 1994, Latest Mesozoic and Cenozoic magmatism in southeastern Alaska, in Plafker, G., and Berg, H.C., eds., The Geology of Alaska: Boulder, Colo., Geological Society of America, The Geology of North America, v. G-1, chap. 19, p. 621-656.

Brew, D.A., 1996, The Coast shear zone in southeastern Alaska-How many and what are they? [abs.]: Geological Society of America, Abstracts with Programs, v. 28, no. 7 p. A-444.

Brew, D.A., 1998a, Comparison of the Insular-Intermontane line (IIL) of southeastern Alaska and the Periadriatic line (PAL) of southern Europe [abs.]: Geological Society of America, Abstracts with Programs, v. 30, no. 5, p. A-7.

Brew, D.A., 1998b, Similarities between the Periadriatic line (PAL) of southern Europe and the Insular-Intermontane line (IIL) of southeastern Alaska [abs.]: XVI Congress of the Carpathian-Balkan Geological Association, Vienna, Austria, August 30-September 2, 1998, Abstracts, p. 86. 
Brew, D.A., and Ford, A.B., 1978, Megalineament in southeastern Alaska marks southwest edge of Coast Range batholithic complex: Canadian Journal of Earth Sciences, v. 15, no. 11, p. 1763-1772.

Brew, D.A., and Ford, A.B., 1985, The southeastern Alaska "coincident zone," in Bartsch-Winkler, S., ed., The United States Geological Survey in Alaska: Accomplishments During 1984: U.S. Geological Survey Circular 967, p. 82-86.

Brew, D.A., and Ford, A.B., 1994, The Coast Mountains plutonicmetamorphic complex between Skagway, Alaska, and Fraser, British Columbia-Geologic sketch and road log: U.S. Geological Survey Open-File Report 94-268, 25 p.

Brew, D.A., and Ford, A.B., 1997, The "Coast Range megalineament" in southeastern Alaska-How does it differ from the "Coast shear zone" [abs.]: Geological Society of America, Abstracts with Programs, v. 29, no. 6, p. A-81.

Brew, D.A., and Ford, A.B., 1998, The Coast Mountains shear zones in southeastern Alaska-Descriptions, relations, and lithotectonic terrane significance, in Gray, J.E., and Riehle, J.R., eds., The U.S. Geological Survey in Alaska: Geologic Studies in Alaska by the U.S. Geological Survey in 1996: U.S. Geological Survey Professional Paper 1595, p. 183-192.

Brew, D.A., Ford, A.B., and Himmelberg, G.R., 1994, Jurassic accretion of Nisling terrane along the western margin of Stikinia, Coast Mountains, northwestern British Columbia: Comment: Geology, v. 22, no. 1, p. 89-90.

Brew, D.A., Ford, A.B., Himmelberg, G.R., and Drinkwater, J.L., 1995, The Coast Mountains Complex of southeastern Alaska and adjacent regions, in Koozmin, E.D., ed., Stratigraphic Notes-1994: U.S. Geological Survey Bulletin 2135, p. 21-28.

Brew, D.A., Himmelberg, G.R., Loney, R.A., and Ford, A.B., 1992, Distribution and characteristics of metamorphic belts in the southeastern Alaska part of the North American Cordillera: Journal of Metamorphic Geology, v. 10, p. 465-482.

Brew, D.A., Horner, R.B., and Barnes, D.F.,1995, Bedrock-geologic and geophysical research in Glacier Bay National Park and Preserve: Unique opportunities of local to global significance, in Engstrom, D.R., ed., Proceedings of the Third Glacier Bay Science Symposium, 1993: Anchorage, Alaska, National Park Service, p. 5-14.

Brew, D.A., and Morrell, R.P., 1980a, Intrusive rocks and plutonic belts of southeastern Alaska: U.S. Geological Survey Open-File Report 80-78, 34 p.

Brew, D.A., and Morrell, R.P., 1980b, Preliminary map of intrusive rocks in southeastern Alaska: U.S. Geological Survey Miscellaneous Field Investigations Map MF-1048, 1 sheet, with text.

Brew, D.A., and Morrell, R.P., 1983, Intrusive rocks and plutonic belts in southeastern Alaska, in Roddick, J.A., ed., Circum-Pacific Plutonic Terranes: Geological Society of America Memoir 159, p. 171-193.

Chardon, D., Andronicos, C.L., and Hollister, L.S., 1998, Mid-Cretaceous to Tertiary transpression and orogen-parallel displacements within the Coast Plutonic Complex, western British Columbia [abs.]: Geological Society of America Abstracts with Programs, v. 30, no. 7, p. A-242.

Clar, E., 1973, Review of the structure of the eastern Alps, in De
Jong, K.A., and Scholten, R., eds., Gravity and Tectonics: New York, London, Sidney, Toronto, J. Wiley and Sons, p. 253-270.

Davidson, C., Rosenberg, C., and Schmid. S.M., 1996, Synmagmatic folding of the base of the Bergell pluton, Central Alps: Tectonophysics, v. 265, p. 213-238.

Debiche, M., Cox, A., and Engebretson, D.C., 1987, The motion of allochthonous terranes across the North Pacific Basin: Geological Society of America Special Paper 207, 49 p.

Engebretson, D.C., Cox, A., and Gordon, R.G., 1985, Relative motions between oceanic and continental plates in the Pacific Basin: Geological Society of America Special Paper 206, $59 \mathrm{p}$.

Fügenschuh, B., Seward, D., and Mancktelow, N., 1997, Exhumation in a convergent orogen: The western Tauern window: Terra Nova, v. 9 , p. 213-217.

Haas, J., Mioc, P., Pamic, J., Tomljenovic, B., Árkai, P., Bérczi-Makk, A., Kovács, S., and Rálisch-Felgenhauer, E., 1998, Continuation of the Periadraitic and NW Dinaridic units in the basement of the Pannonian Basin [abs.]: XVI Congress of the Carpathian-Balkan Geological Association, Vienna, Austria, August 30-September 2, 1998, Abstracts, p. 199.

Handy, M.R., Franz, L., Heller, F., Janott, B., and Zurbriggen, R., 1999, Multistage accretion and exhumation of the continental crust (Ivrea section, Italy and Switzerland): Tectonics, v. 18, no. 6, p. 1154-1177.

Hippolyte, J.-C., Badescu, J., and Constantin, P., 1999, Evolution of the transport direction of the Carpathian belt during its collision with the eastern European platform: Tectonics, v. 18, no. 6, p. 1120-1138.

Hollister, L.S., and Andronicos, C.L., 1997, A candidate for the Baja British Columbia fault system in the Coast plutonic complex: GSA Today, v. 7, no. 11, p. 1-7.

Hutton, D.H.W., and Ingram, G.M., 1992, The Great Tonalite Sill of southeastern Alaska and British Columbia: Emplacement into an active contractional high angle reverse shear zone [extended abs.]: Transactions of the Royal Society of Edinburgh: Earth Sciences, v. 83, p. 383-386.

Ingram, G.M., and Hutton, DH.W., 1994, The Great Tonalite Sill: Emplacement into a contractional shear zone and implications for Late Cretaceous to early Eocene tectonics in southeastern Alaska and British Columbia: Geological Society of America Bulletin, v. 106, p. 715-728.

Jachens, R.C., 1984, Interpretation of the aeromagnetic data, in Mineral Resources of the Tracy Arm-Fords Terror Wilderness Study Area and Vicinity, Alaska: U.S. Geological Survey Bulletin 1525, p. 53-62.

Karl, S.M., Hammarstrom, J.M., Kunk, M., Himmelberg, G.R., Brew, D.A., Kimbrough, D.L., and Bradshaw, J.Y., 1996, Tracy Arm transect: Further constraints on the uplift history of the Coast plutonic complex in southeastern Alaska [abs.]: Geological Society of America, Abstracts with Programs, v. 28, no. 7, p. A-312.

Klepeis, K.A., Crawford, M.L., and Gehrels, G., 1998, Structural history of the crustal-scale Coast shear zone north of Portland Canal, southeast Alaska and British Columbia: Journal of Structural Geology, v. 20, p. 883-904. 
Parrish, R.R., 1883, Cenozoic thermal evolution and tectonics of the Coast mountains of British Columbia. 1, Fission track dating, apparent uplift rates, and patterns of uplift: Tectonics, v. 2, p. 601-631.

Quick, J.E., 1998, Magmatic underplating: Observations from a deep-crustal intrusive complex in the Ivrea-Verbano zone of the northwestern Italian Alps [abs.]: Geological Society of America Abstracts with Programs, v. 30, no. 7, p. A-244.

Quick, J.E., and Sinigoi, S., 1992, eds., Ivrea-Verbano zone workshop abstracts, 1992: U.S. Geological Survey Circular 1089, 30 p.

Quick, J.E., Sinigoi, S., and Mayer, A.,1994, Emplacement dynamics of a large mafic intrusion in the lower crust, Ivrea-Verbano zone, northern Italy: Journal of Geophysical Research, v. 99, no. B11, p. 21599-21573.

Rusmore, M.E., Gehrels, G.E., and Woodsworth, G.J., 1998, Alongstrike variations on the Coast shear zone: Bearing on the origin of the central gneiss complex, Coast Mountains, British Columbia [abs.]: Geological Society of America, Abstracts with Programs, v. 30 , no. 5, p. A-63.

Saltus, R.W., Hudson, T.L., and Connard, G.G., 1999, A new magnetic view of Alaska: GSA Today, v. 9, no. 3, p. 1-6.

Schmid, S.M., Aebli, H.R., Heller, F, and Zingg, A., 1989, The role of the Periadriatic line in the tectonic evolution of the Alps, in Coward, M.P., Dietrich, D., and Park, R.G., eds., Alpine Tectonics: Geological Society Special Publication No. 45, p. 153-171.
Schmid, S. M., Pfiffner, 0.A., Froitzheim, N., Schonborn, G, and Kissling, E., 1996 , Geophysical-geological transect and tectonic evolution of the Swiss-Italian Alps: Tectonics, v. 15, no. 5, p.1036-1064.

Selverstone, J., 1988, Evidence for east-west crustal extension in the eastern Alps: Implication for the unroofing of the Tauern window: Tectonics, v. 7., no. 1, p. 87-105.

Simkin, T., Unger, J.D., Tilling, R.I., Vogt, P.R., and Spall, H., 1994, This dynamic planet: U.S. Geological Survey Map, scale 1:30,000,000 (at the equator).

Stowell, H.H., and McClelland, W.C., eds., 2000, Tectonics of the western Coast Mountains, southeastern Alaska and British Columbia: Geological Society of America Special Paper 343.

Sprenger, W.L., 1996, Das Periadriatische Lineament südlich der Lienzer Dolomiten: Geologische Bundesanstalt [Austria], Abhandlungen Band 52, $220 \mathrm{p}$.

Wybraniec, S., Zhou, S., Thybo, H., Forsberg, R., Perchuc, E., Lee, M., Demianov, G.D., and Strakov, V.N., 1998, New map of Europe's gravity field: EOS, Transactions, American Geophysical Union, v. 79. no. 37, p. 437,442 .

Reviewers: R.W. Tabor, C.M. Davidson, L. Ratschbacher, H.S. Stowell, and J.S. Oldow 


\title{
Quaternary Geology, Cold Bay and False Pass Quadrangles, Alaska Peninsula
}

\author{
By Frederic H. Wilson and Florence R. Weber
}

\section{Abstract}

Recent mapping and interpretation of Quaternary geologic features has improved our understanding of the interaction between volcanic, glacial, and tectonic activity in the Cold Bay and False Pass 1:250,000-scale quadrangles on the Alaska Peninsula. The glacial and volcanic record of the map area strongly suggests that continental-shelf glaciations and two massive volcanic centers were the dominant controls over landscape development during Pleistocene time. Ancestral Morzhovoi and Emmons Volcanoes were major impediments to flow of shelf glaciers during much of the Pleistocene. Our mapping suggests that the area around Emmons Volcano may have also been an important source area for glaciers during this period. Our data further indicate that Frosty Volcano developed late in the Pleistocene, having had no apparent impact on early Brooks Lake glacial advances but serving as a source area for later glacial advances during late Brooks Lake time. We also believe that major Holocene eruptions of Frosty Volcano have yielded multiple debris and ash flows resulting in the construction of a new south summit cone that filled an earlier crater. Frosty Volcano was the source area for multiple Holocene glacial advances, and its flanks preserve the best record of Neoglacial activity in the map area.

\section{Introduction}

Recent mapping and interpretation of Quaternary geologic features has improved our understanding of the interaction between volcanic, glacial, and to a lesser extent, tectonic activity in the Cold Bay and False Pass 1:250,000-scale quadrangles on the Alaska Peninsula. This mapping (Wilson and others, 1997) was compiled with earlier mapping conducted as part of the USGS Alaska Mineral Resource Assessment Program (AMRAP) and the Geothermal Energy Program. Previous geologic mapping in the region, which constituted an invaluable database for our studies, was conducted by Kennedy and Waldron (1955), Waldron (1961), Burk (1965), Funk (1973), McLean and others (1978), and DuBois and others (1989). Field studies by the authors were conducted over an extended span of years, including 1983, 1988, 1990-91, and 1996 by Wilson and 1996 by Weber. Our interpretation of Quaternary units and events is mostly based on air photo interpretation and correlation with similar units in quadrangles to the north and east.

It is important here to note our near total lack of success in acquiring rigorous age control on the events we can document through our fieldwork and air photo interpretations. There are, of course, multiple reasons for this - the most important were our very limited time in the field and that material suitable for age determination (essentially radiocarbon dates) is rare and often found in nondiagnostic localities. Clearly, the lack of radiocarbon-datable material associated with glacial deposits or tephra (only the Fisher or Funk ash is well controlled), the youth of the events, and the low potassium content of the rocks (preventing reliable $\mathrm{K}$-Ar dates) confounds our attempts to apply ages. Much of the history described postdates the development of Emmons Caldera, itself not tightly dated (140 $\mathrm{ka} \pm 25-50 \mathrm{ka}$ ). However, the lack of age control on Quaternary events is not restricted to the Cold Bay region and is a problem along the entire Alaska Peninsula.

With respect to the Holocene, the one radiocarbon date that we believe helps to define an age is on a Neoglacial moraine derived from Frosty Peak. Yielding a maximum age for the advance of about 1,060 yr B.P., one could surmise that this is not a Little Ice Age advance. Given that the particular glacier advanced $5 \mathrm{~km}$ down valley, whereas other Neoglacial moraines recognized in the area are not more that $1 \mathrm{~km}$ beyond existing glaciers or cirques, this is an unusual circumstance.

\section{Quaternary Glacial Units}

A Quaternary glacial sequence (table 1) was originally defined for the Cold Bay vicinity by Funk (1973). Later, Detterman (1986) slightly refined this sequence and incorporated it into an Alaska Peninsula stratigraphy, showing correlations of Quaternary units the length of the Peninsula. The Brooks Lake drift (see table 1), formerly called the Brooks Lake Glaciation, is generally accepted as the late Wisconsin or last glacial maximum (LGM) on the Alaska Peninsula. Although recent work at the northern end of the Alaska Peninsula (Riehle and Detterman, 1993; Mann and Peteet, 1994; Stilwell 
and Kaufman, 1996) has questioned the assignment of some deposits to particular glacial episodes or advances in that region, the general stratigraphy, nonetheless, seems to hold up rather well. Using largely air photo interpretation and limited time on the ground we have attempted to apply this regional stratigraphy to the geology of the Cold Bay and False Pass region. Ground "truth" that would allow detailed description and assignment of units is limited due to restrictions on time in the field imposed by weather and funding. It is clear that a universal application of the general stratigraphic framework established for the Alaska Peninsula can be locally unworkable due to local climatic, topographic, and volcanic conditions. These local conditions, particularly growth and degradation of volcanic edifices, may have resulted in non-synchronous glacial advances. In addition, tectonic instability resulted in the incomplete preservation of deposits of some episodes (Winslow and Johnson, 1989a). In spite of these factors, we believe that we have developed a reasonable scenario for the geologic history of the region; this scenario is a hypothesis for which we encourage further testing.

\section{Late Quaternary History of the Cold Bay Region}

We have reconstructed the sequence of glacial and volcanic events during part of the Pleistocene and Holocene in the Cold Bay region (fig. 1). We have divided the discussion of that history into regional sections because, although there are similarities across the areas, each part of the region has a distinct character. From northeast to southwest, the regional sections include (1) the Emmons buttress region, the area between Pavlof Bay and Cold Bay, (which includes Emmons Caldera and Mt. Dutton), (2) the area between Cold and Morzhovoi Bays, discussed as the Morzhovoi Volcano buttress region, and (3) the Ikatan Peninsula and Unimak Island area. Each of these discussions reports our data and describes a possible scenario for the section or area.

\section{Quaternary Glacial-Volcanic Interactions}

In the Cold Bay-False Pass region, the interactions of glaciers and active volcanoes have had a strong influence on the type and morphology of Quaternary deposits. Elsewhere on the Alaska Peninsula (for example, Detterman and others, 1981; Detterman, 1986), Quaternary glacial and volcanic deposits can be mapped and interpreted almost independently. In our map area, however, the active volcanoes of Unimak Island (Shishaldin, Isanotski Peaks, and Roundtop), Frosty Peak, Morzhovoi Volcano, Mount Dutton, and the Emmons Caldera-Pavlof group of volcanoes have exerted control on the glaciers of the region. On Unimak Island, deposits of presumed Brooks Lake age indicate that Shishaldin Volcano in the adjacent Unimak 1:250,000-scale quadrangle may be a largely Holocene feature. Fournelle (1988) mapped parts of Shishaldin Volcano, particularly its northwest flank and he did not report

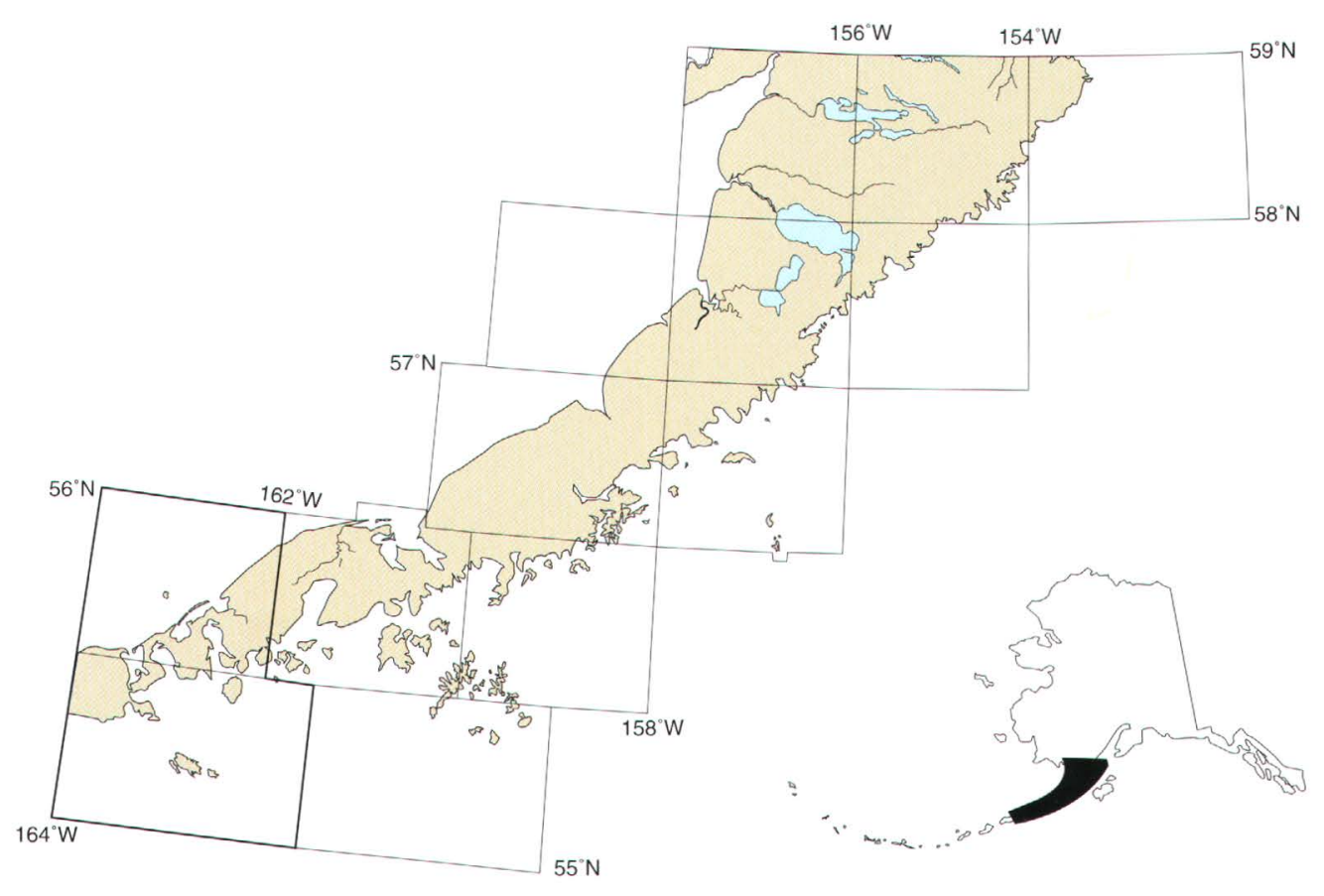

Figure 1. Map showing the location of the Cold Bay and False Pass region. 
Table 1. Correlation of Alaska Peninsula glacial sequences.

\begin{tabular}{|c|c|c|c|c|c|c|c|}
\hline Time division & $\begin{array}{l}\text { Cold Bay area } \\
\text { (Funk, 1973) }\end{array}$ & & $\begin{array}{l}\text { aska Peninsula } \\
\text { etterman, 1986) }\end{array}$ & \multicolumn{2}{|c|}{$\begin{array}{l}\text { Northern Alaska Peninsula } \\
\text { (Stilwell and Kaufman,1996) }\end{array}$} & \multicolumn{2}{|c|}{$\begin{array}{l}\text { This report (based on the } \\
\text { Cold Bay region) }\end{array}$} \\
\hline Holocene & Frosty drift & \multicolumn{2}{|c|}{ Neoglaciation } & \multicolumn{2}{|l|}{--} & \multicolumn{2}{|c|}{ Neoglaciation } \\
\hline \multirow[b]{2}{*}{ Late Wisconsin } & & & & Ukak & & & \\
\hline & $\begin{array}{l}\text { Russell Creek drift } \\
\text { Cold Bay unit }\end{array}$ & \multirow{2}{*}{ 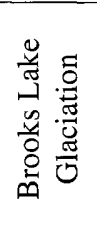 } & $\begin{array}{l}\text { Iliuk advance } \\
\text { Newhalen advance }\end{array}$ & \multirow{2}{*}{ 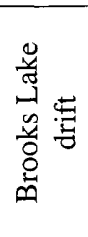 } & $\begin{array}{l}\text { Iliuk } \\
\text { Newhalen }\end{array}$ & \multirow{3}{*}{ 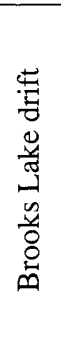 } & $\begin{array}{l}\text { Iliuk advance } \\
\text { Newhalen } \\
\text { advance }\end{array}$ \\
\hline \multirow[b]{2}{*}{ Early Wisconsin } & & & $\begin{array}{l}\text { Iliamna advance } \\
\text { Kvichak advance }\end{array}$ & & $\begin{array}{l}\text { Undivided } \\
\text { Iliamna and } \\
\text { Kvichak } \\
\end{array}$ & & \\
\hline & Morzhovoi Bay unit & \multicolumn{2}{|c|}{ Mak Hill drift sheet } & \multicolumn{2}{|c|}{ Mak Hill } & & $\begin{array}{l}\text { Iliamna advance } \\
\text { Kvichak } \\
\text { advance }\end{array}$ \\
\hline \multirow[t]{2}{*}{ Pre-Wisconsin } & Not present & \multicolumn{2}{|c|}{ Johnston Hill drift sheet } & & & \multicolumn{2}{|c|}{$\begin{array}{l}\text { Mak Hill drift sheet } \\
\text { Johnston Hill drift sheet }\end{array}$} \\
\hline & Not present & \multicolumn{2}{|c|}{ Oldest drift } & \multicolumn{2}{|c|}{ Oldest drift(?) } & \multicolumn{2}{|c|}{ Oldest drift } \\
\hline
\end{tabular}

any glacially derived deposits, except for those associated with modern glaciers. During our examination of air photos covering Unimak Island, no glacial deposits of Brooks Lake age derived from Shishaldin Volcano were identified and glacial deposits derived from elsewhere or deflected around the other volcanoes of the island do not show any apparent influence from Shishaldin Volcano. By implication, Shishaldin Volcano is largely a post-Wisconsin feature.

At many localities in the Cold Bay vicinity, a distinctive volcanic ash deposit has been mapped (see Funk, 1973). Later workers referred to this as the "Funk" ash and used it in correlations throughout the area. According to T.P. Miller (oral commun., 1997), this ash is derived from the eruption at 9,100 yr B.P. of Fisher Caldera on Unimak Island west of the map area (Miller, 1990). The presence of the Funk ash overlying many of the glacial sequences in the region provides one of the strongest means we have of controlling ages of these sequences and separating definitely Neoglacial and probable late Wisconsin deposits.

\section{Emmons Buttress Region}

A group of high mountains centered around present-day Mt. Emmons, Mt. Dutton, and the Aghileen Pinnacles at one time formed an island and acted as a buttress to deflect massive northward-flowing glaciers from the continental shelf to the south. The end moraines of several of these vast ice bodies were deposited to form the heads of Pavlof Bay, Cold Bay, and other bays, connecting several former islands to form the presently continuous landmass of the Alaska Peninsula. In addition to the Emmons buttress, ancestral Morzhovoi Volcano and the range of mountains between the west side of presentday Morzhovoi Bay and False Pass also served as buttresses to deflect ice flow from the shelf glaciers.

The Emmons buttress includes the oldest bedrock in the map area. Sandstone of the Indecision Creek Sandstone and Snug Harbor Siltstone Members of the Naknek Formation of Late Jurassic age crop out in the vicinity of Black Hill (fig. 2). The Amoco Production Company Cathedral River \#1 exploratory well (Detterman, 1990), drilled to $14,301 \mathrm{ft}$ $(4,360 \mathrm{~m})$ in $1973-74$ on the Cathedral River, started in the Snug Harbor Siltstone Member of the Naknek Formation (see Detterman and others, 1996). It penetrated a thick Mesozoic section, including most of the Naknek Formation, the Shelikof, Kialagvik, and Talkeetna Formations, and bottomed in the Kamishak Formation of Late Triassic age. The Emmons buttress contains the most distal exposures of Mesozoic rocks on the Alaska Peninsula; farther west, bedrock is entirely of Tertiary or Quaternary age.

Although the Emmons buttress deflected the shelf glaciers, it was also, at the same time, high enough to support its own mountain glaciers, not only during the period of deposition of the extensive Wisconsin-age moraines at the heads of Cold Bay and Pavlof Bay but during earlier glaciations as well. Fortunately, the deposits of some these earlier episodes were protected on the northwest (lee) side of the Emmons buttress from scouring by shelf glaciers. Classic U-shaped valleys on ancestral Morzhovoi Volcano indicate it also supported a number of mountain glaciers; however, older glacial deposits that may have been derived from this volcano have been covered by the construction of Frosty Volcano on the north or removed by the shelf glaciers on its other flanks.

The northwest side of Emmons buttress is relatively inaccessible and little of the glacial story has been studied on the ground, but there are available excellent aerial photos taken during topographic mapping. In addition, the eruptive history of the volcanoes in the buttress group is being studied as a 


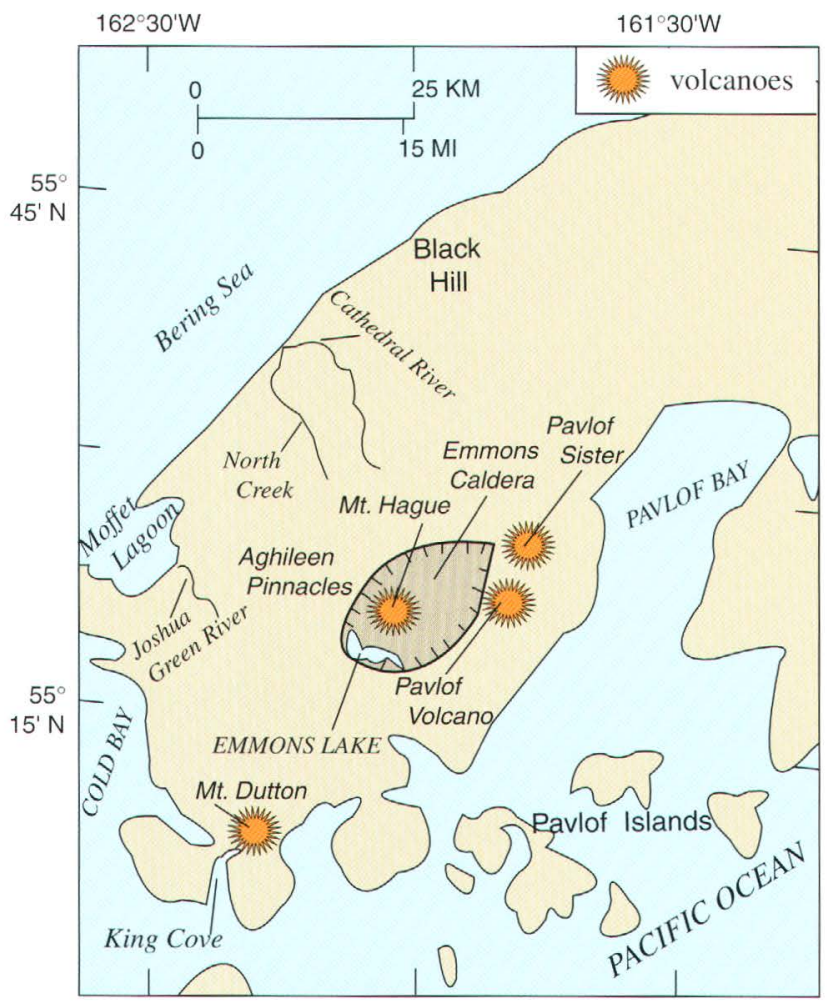

Figure 2. Index map showing location of the Emmons buttress region.

part of the work of the Alaska Volcano Observatory. Largely through study of the 1:40,000-scale black and white and colorinfrared aerial photographs, we are able to suggest the following sequence (from oldest to youngest) of events impacting the Emmons buttress (see table 2).

The oldest evidence of glaciation on the Emmons buttress is bedrock scouring in the vicinity of Black Hill (fig. 2); see also Wilson and others (1997). The bedrock of Black Hill and the surrounding country is composed of sandstone of the Naknek Formation. The morphology of the mountains indicate that they have been glacially overridden. In addition, Detterman's 1983 field notes report his observation of cobbles that he thought were of probable glacial origin at an elevation of about $750 \mathrm{ft}$ (about $225 \mathrm{~m}$ ). These cobbles provide evidence for glaciation corresponding to the "oldest drift" of Detterman (1986).

The oldest generally visible deposits of mountain (and possibly shelf) glaciation occupy the lowest parts of the Cathedral River valley in the Cold Bay quadrangle. These moraines are dark toned on the air photos, and, from ground observation in the adjoining Port Moller quadrangle, we believe they are probably covered by a substantial thickness $(1 \mathrm{~m}$ ?) of humus, dark soil, and ash layers. The normal irregular topography of these moraines has been extensively subdued by deposition of volcanic air-fall deposits, probable marine transgression, and weathering; reliable distinction between ground and end or lateral moraines and the exact locations of glacial limits cannot be made with certainty. However, we believe from the evidence available that the outermost extent of the deposits is presently under the Bering Sea. We also believe that these deposits may correlate with the Johnston Hill drift of Detterman (1986) based on their position and morphological character. Recent work by Kaufman and others (1995, p. 57) on the northern Alaska Peninsula near King Salmon strongly suggests that the Johnston Hill and Mak Hill moraines of Detterman (1986) may "... represent local ice thrusting related to glacier-bed dynamics during a single glacial phase, rather than regionally and climatically significant ice-marginal positions." Kaufman and others (1995) also suggest correlation of the Johnston Hill and Mak Hill moraines with the Halfmoon Bay drift of (Muller, 1953), which they suggest has an early marine oxygen-isotope stage- 5 age (ca. $110 \mathrm{ka}$ ). Given this interpretation, deposits we have interpreted as associated with the Johnston Hill and Mak Hill moraines may represent multiple episodes in a single glacial phase. Alternatively, the so-called Johnston Hill drift we recognize may be equivalent to the oldest drift of Detterman (1986) and the scouring and cobbles preserved at Black Hill may provide evidence for an even earlier event not apparent in the King Salmon area.

The arms of a better preserved older morainal arc, which we correlate with the Mak Hill glaciation of Detterman (1986), can be seen farther up the slope enclosing the valley of North Creek to the west of Cathedral River. The Mak Hill moraine, like the Johnston Hill moraine, is also dark toned and probably has soil/ash cover similar to the Johnston Hill deposits. Subdued knob-and-kettle topography is preserved at many places on this arcuate ridge, but very significantly, the outward edge of this moraine shows evidence of modification by the wash of water on a strandline. Instead of a normal end-morainal humpy push-profile, the leading edge of the moraine has a smooth, gently outward-facing slope. The strandline apparently stood slightly below the crest of the moraine at a present-day altitude of between 75 and $90 \mathrm{~m}$ (see table 2). On North Creek, a moraine that may be a lesser second advance of the Mak Hill glaciation was deposited at an elevation above the strandline and does not show effects of a higher sea level.

In the northeast part of the Cold Bay quadrangle, on the north side of Black Hill, there is a moraine having similar modified knob-and-kettle characteristics as the oldest of the Mak Hill moraines described above. This feature appears to emerge from a ridge overlain by one of the Pavlof Bay head moraines of Wisconsin age and descends off the hill toward the ocean after crossing a narrow coastal plain. At the foot of the hill, the typical humpy morainal topography has been smoothed by marine erosion below the elevation of 75 to 90 $\mathrm{m}$, reconfirming the sea level determined on the North Creek Mak Hill moraine.

The next younger event seen on aerial photos is displayed in an unusual, relatively light-toned series of low ridges on the slopes north of the Joshua Green River (fig. 3). These ridges seem to drape across the slopes, extending downhill toward the Bering Sea. Informally termed "the snake" during mapping because of their form, they form a continuous band as they wind across the upper part of North Creek and smaller drainages. 
Table 2. Provisional Quaternary history of the Emmons buttress region.

[See text for explanation; see Wilson and others (1997) for radiocarbon data]

\begin{tabular}{|c|c|c|}
\hline Event & $\begin{array}{l}\text { Suggested } \\
\text { age }\end{array}$ & $\begin{array}{l}\text { Calibrated radiocarbon age } \\
\text { (yr. B.P.) }\end{array}$ \\
\hline Historic eruptions & Holocene & \\
\hline \multicolumn{3}{|l|}{ Neoglacial deposits missing } \\
\hline $\begin{array}{l}\text { Tephra beds ("Funk [Fisher] ash") in Cold Bay area lying } \\
\text { stratigraphically above Cold Bay moraine correlated with } \\
\text { the Newhalen advance (Wilson and others, 1997) }\end{array}$ & post-Pleistocene $9 \mathrm{ka}$ & 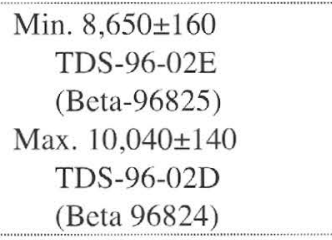 \\
\hline Evidence for eruptive intervals in buttress area & $\begin{array}{l}\text { late Pleistocene } \\
\text { (Wisconsin) }\end{array}$ & \\
\hline $\begin{array}{l}\text { Highstand of the sea, roughly } 16 \text { m above MSL (Jordan, } \\
\text { 1997) }\end{array}$ & $\begin{array}{l}\text { late Wisconsin or early } \\
\text { Holocene }\end{array}$ & \\
\hline Brooks Lake drift Iliuk advance missing on Emmons buttress & late Wisconsin & \\
\hline $\begin{array}{l}\text { Brooks Lake drift Newhalen advance missing on Emmons } \\
\text { buttress }\end{array}$ & late Wisconsin & \\
\hline $\begin{array}{l}\text { Brooks Lake drift Iliamna advance, well developed alpine } \\
\text { and shelf glacier moraines on west side of buttress }\end{array}$ & Wisconsin & \\
\hline $\begin{array}{l}\text { Brooks Lake drift Kvichak advance, well developed alpine } \\
\text { and shelf glacier moraines on west side of buttress }\end{array}$ & Wisconsin & \\
\hline $\begin{array}{l}\text { Deposit of volcanoglacial or debris flow northwest of Mt. } \\
\text { Emmons and regionally extensive debris apron }\end{array}$ & $\begin{array}{l}\text { Timing relative to } \\
\text { highstand of sea } \\
\text { unknown }\end{array}$ & \\
\hline $\begin{array}{l}\text { Highstand of the sea, shoreline developed on Mak Hill drift } \\
\text { at elevation of } 75-90 \mathrm{~m}\end{array}$ & $\begin{array}{r}\text { pre-Wisconsin } \\
\text { interstadial }\end{array}$ & \\
\hline Mak Hill glacial episode & $\begin{array}{l}\text { pre-Wisconsin } \\
\quad(110 \mathrm{ka} ?)\end{array}$ & \\
\hline $\begin{array}{l}\text { Johnston Hill glacial episode, extremely subdued moraines } \\
\text { and outwash }\end{array}$ & pre-Wisconsin & \\
\hline $\begin{array}{l}\text { Oldest glaciation of Detterman (1986), inferred from bedrock } \\
\text { scouring and probable glacial erratic cobbles }\end{array}$ & pre-Wisconsin & \\
\hline
\end{tabular}

They seem to conform to valley configuration and form "V" shapes pointing downstream at their lowest extents in the drainage valleys. In one small drainage, the ridges trend down into a preexisting gully. These ridges probably represent a mixed volcano-glacial event related to the caldera-forming eruption of ancestral Mt. Emmons. This deposit is composed primarily of large angular volcanic rocks and minimal fine sediment and appears to be no more than a few $(<10)$ meters thick. Because of the lack of fine material, we are reluctant to call this deposit a lahar or volcanic mudflow. We have considered the possibility that this deposit may be the result of a jökulhlaup (Björnsson, 1975), however, descriptions of jökulhlaups emphasize the large proportion of water ( 80 percent or more). The character of the "snake" and deposits downslope do not indicate the passage of large volumes of fluid. Jònsson (1982) describes a series of "volcanoglacial debris flows" from Katla Volcano in Iceland. In gross aspect these could be similar to the "snake," although they are dominantly (60-70 percent) fine-grained material, largely pumice, having a grain size between 0.5 and $4 \mathrm{~mm}$. However, a later paper on the same deposits (Tòmasson, 1996) suggests that these were truly the deposits of a water-dominant (greater than 80 percent) jökulhlaup and not a volcanoglacial debris flow. Because the Katla eruption that produced these deposits in 1918 was actually observed and still such a fundamental controversy over their mechanism of formation exists, it is clear that it will be difficult to resolve the nature of the "snake." We believe that it represents some type of volcanoglacial debris flow.

An extensive debris deposit covers many of the higher northwestern slopes of the Emmons buttress region (fig. 2) and overlaps the "snake" and the Mak Hill moraine. This deposit consists of dark-colored, poorly sorted volcanic material ranging from large meter-sized angular blocks to mud that blankets older deposits to varying depths. The debris deposits are present as much as $20 \mathrm{~km}$ northwest of Mt. Emmons. We believe that, because this debris has such a wide distribution, it was associated with a major volcanic eruption. However, we have no data to indicate if it was hot or contained juvenile material at the time of emplacement. T.P. Miller (oral commun., 1999) 


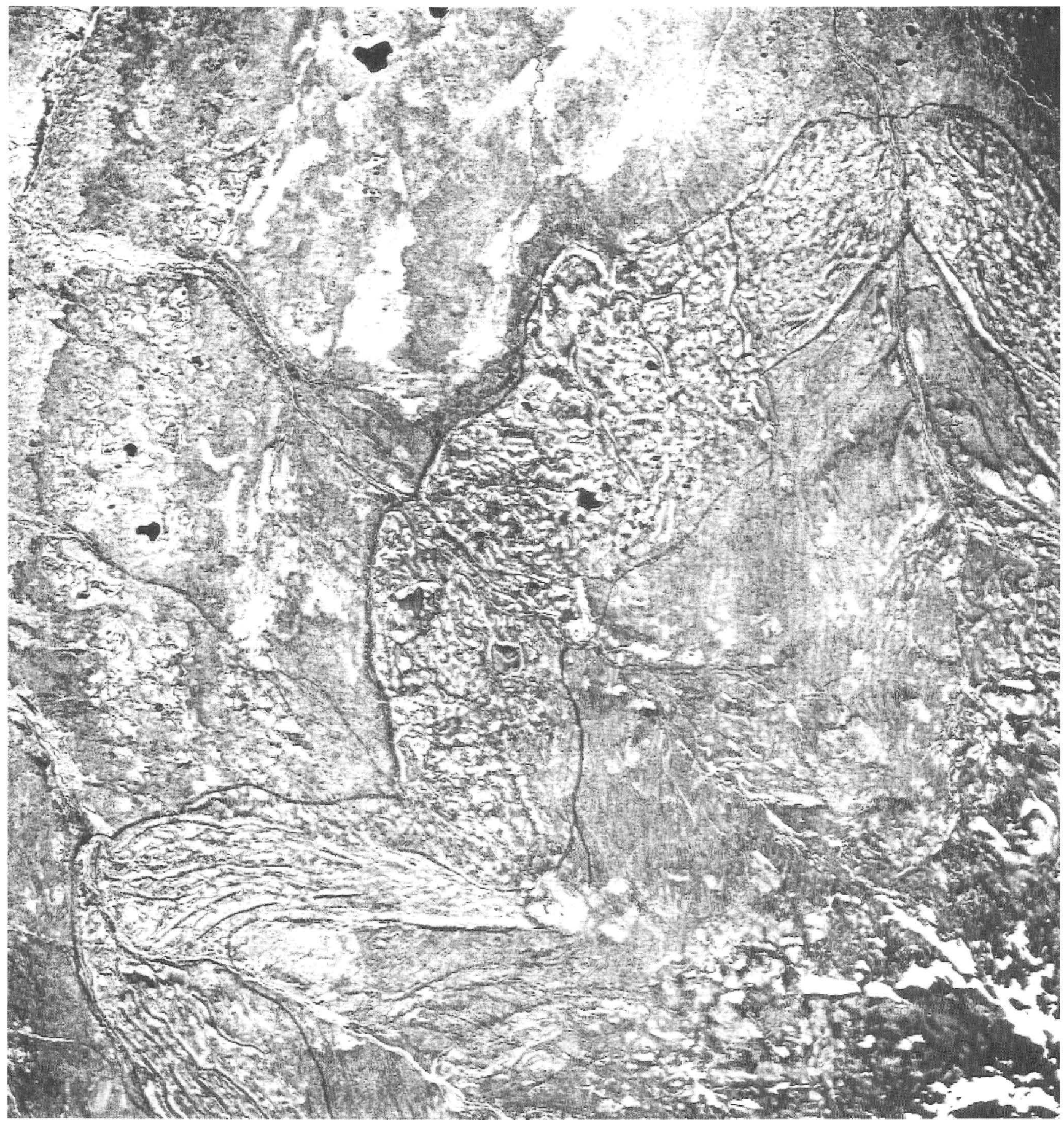

Figure $\mathbf{3 A}$. Aerial photograph showing the southern portion of "the snake," volcanoglacial debris-flow deposits. Photograph is oriented with north diagonal across the picture to the upper left corner. On the left edge of the photograph, moraine of the Mak Hill drift is visible, showing the strandline at 75- to 90-m elevation discussed in the text. The "snake" meanders across the center of the photograph, overlying the moraine in the lower left corner (note-the appearance of the snake has been enhanced by outlining on the reproduced image). Visible in the lower right corner of the photograph are the volcanic debris-flow deposits, which overlie the snake. Photograph is number 1112 of Mission 150, flown June 18, 1962, by the U.S. Air Force. Scale as shown here is about 1:80,000.

does not believe that this deposit was associated with an eruption, particularly the caldera-forming eruptions of the Emmons system. In some areas where he has mapped a similar deposit north of Mt. Dutton, he reports (oral commun., 1998) that it is interbedded with glacial deposits. In our view, the occurrence of these debris deposits at high elevation in a radial pattern on the north and west quadrants surrounding Emmons caldera on slopes truncated by later glacial erosion strongly suggest 


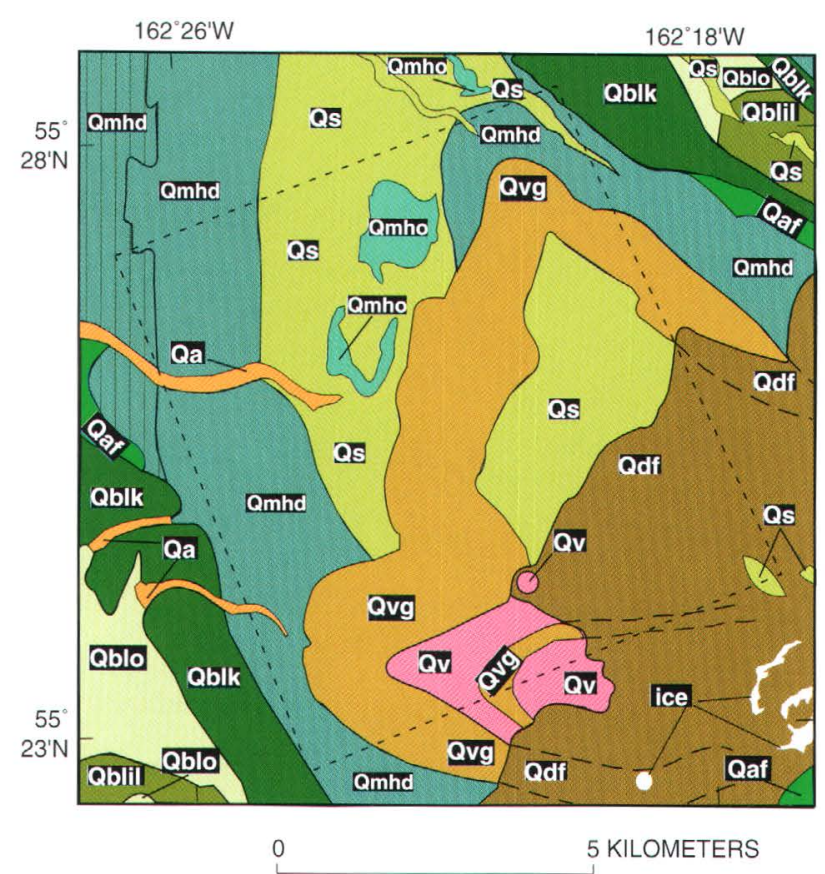

EXPLANATION

Os Undivided surficial deposits

Qa Alluvial deposits

Qaf Alluvial fan deposits

\section{Brooks Lake Glaciation}

Glacial deposits

Qblo Outwash, undivided

Qbill Iliamna advance end moraine

Qblk Kvichak advance end moraine

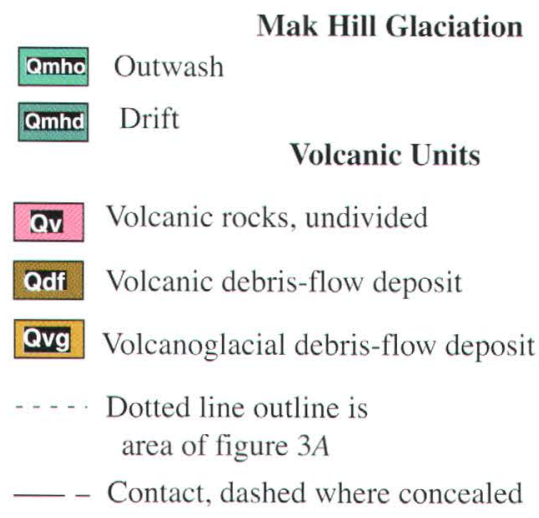

Figure $3 \boldsymbol{B}$. Section of geologic map southwest of North Creek (Wilson and others, 1997) showing geologic interpretation of the area of the photograph. Approximate area of photograph is dotted outline on map. Scale of map is about 1:125,000.

a genetic association with ancestral Emmons Volcano. Wadge and others (1995) describe debris avalanche deposits in Chile on the flank of Socompa Volcano that may be a partial analog for these deposits on the Emmons buttress.

Ancestral Mt. Emmons may have been the source of the Old Crow tephra (Miller and Smith, 1987), well known as a stratigraphic marker in much of southwestern and Interior Alaska and the Yukon (Hamilton and Brigham-Grette, 1992). Tentative dating of the earliest of the Emmons eruptions, by correlation with the Old Crow tephra, indicates an age of about 140 ka (T.P. Miller, oral commun., 1996). Map patterns indicate that these debris deposits postdate the Mak Hill glacial deposits mentioned earlier which are possibly correlated with the Halfmoon Bay drift by Kaufman and others (1995) having a suggested age of less than $110 \mathrm{ka}$. Hence, it appears that these debris deposits could be younger than $110 \mathrm{ka}$. Therefore the extensive debris deposit would not be related to the postulated Emmons eruption that produced the Old Crow tephra; alternatively, Emmons may not be the source of the Old Crow tephra and our Mak Hill really might not correlate with Half Moon Bay in any case.

A major glacial episode included in Funk's (1973) Cold Bay unit, which Detterman (1986) correlated with the Kvichak advance of the Brooks Lake glaciation, followed the deposit of the debris mentioned above. Mountain glaciers enlarged the upper valleys of the Joshua Green River, North Creek, and Cathedral River into deep canyons that cut through the volcanic debris-flow and lahar deposits and well into the underlying bedrock. Well-defined, classic end moraines having relatively fresh looking knob-and-kettle topography were deposited in each of these valleys. They are light toned on air photos, probably because soil and vegetation are sparingly developed on the gravelly ridges. Part of the end moraine of this glacial advance on Joshua Green River is currently under Moffet Lagoon. However, there is no evidence to indicate that other moraines of this glacial advance, located below 75 to $90 \mathrm{~m}$ on land, were ever affected by the early highstand of the sea. Hence, we believe this stage clearly postdates the 75- to 90-m sea-level stand. On the southern part of the Emmons buttress, we believe that high-level morainal deposits of the shelf glaciers indicate the ice masses of the shelf and mountain areas were continuous.

Another glacial advance followed, correlated on the basis of position and surface characteristics with the Iliamna advance of the Brooks Lake glaciation by Detterman (1986), leaving similar morainal deposits in each of these valleys but upstream of the Kvichak shelf and alpine moraines. In Joshua Green valley, a moraine of this advance forms a complete arc cut only by the river close to modern sea level. This moraine provides the key to date the mountain glacial sequence. The left arm of the Joshua Green River morainal ridge merges with one of the shelf glacier moraines that delineate the head of Cold Bay (fig. 4). Based on the character of the deposits, both from aerial photos and ground observation, we believe these moraines are essentially coeval.

In the immediate area of Cold Bay, two even younger advances from the shelf icecap are provisionally correlated with the Newhalen and Iliuk advances of the Brooks Lake 


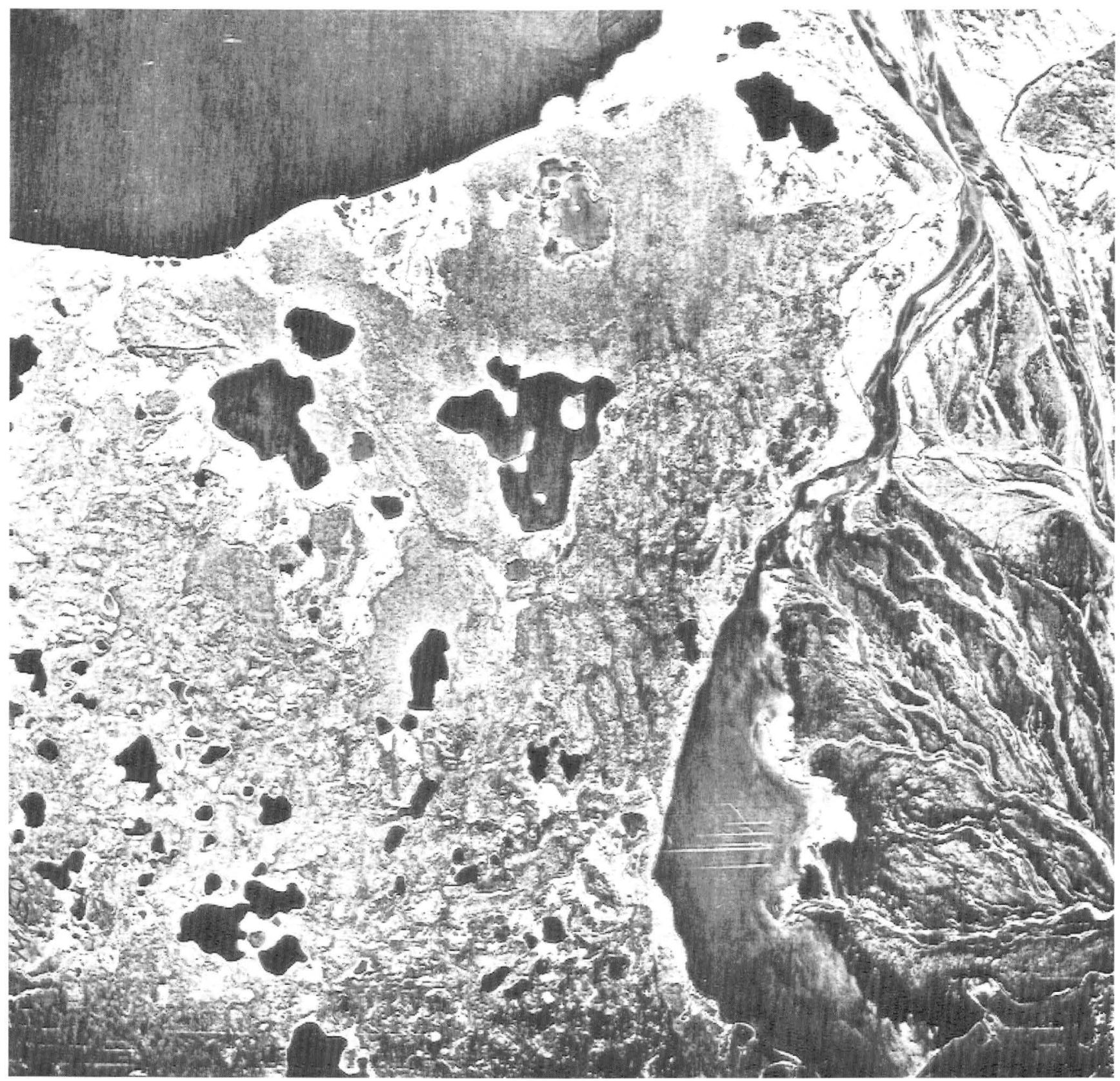

Figure 4A. Aerial photograph showing merging of moraines from the Joshua Green River valley and Cold Bay. Smaller morainal ridge in center of photograph is moraine of alpine(?) glacier flowing down Joshua Green River valley. It merges with moraine of the Iliamna advance derived from the shelf and flowing into and through Cold Bay. The form of the moraine of the alpine glacier indicates that the glacier was deflected northward at time of deposition. This image is not as clear as the original photograph; the original shows no indication that the moraines were any different in age. A thin ridge of moraine is just visible between the lakes in front of the shelf glacier moraine; this ridge appears overrun by the alpine glacier. Upper left corner of photograph is the Bering Sea. Photograph is oriented with north diagonal across the picture, pointing toward the upper left corner (note - the appearance of the snake has been enhanced by outlining on the reproduced image). Photograph 1193 of Mission 150, flown June 19, 1962, by the U.S. Air Force. Scale as shown here is about 1:80,000.

drift. However, with few exceptions, the remnants of no younger moraines can be identified in the canyon valleys of the Emmons buttress. The exceptions occur in the Cathedral Valley, where a deposit we suggest might be a small moraine is located at the junction between its east and west forks. This deposit occurs as a set of three ridges that form a remnant arc partially across the east fork valley. Across the valley, a deposit shown on the map of Wilson and others (1997) as a moraine of the Iliamna advance, has a morphology that suggests the arcuate ridge from across the valley may have originally joined 


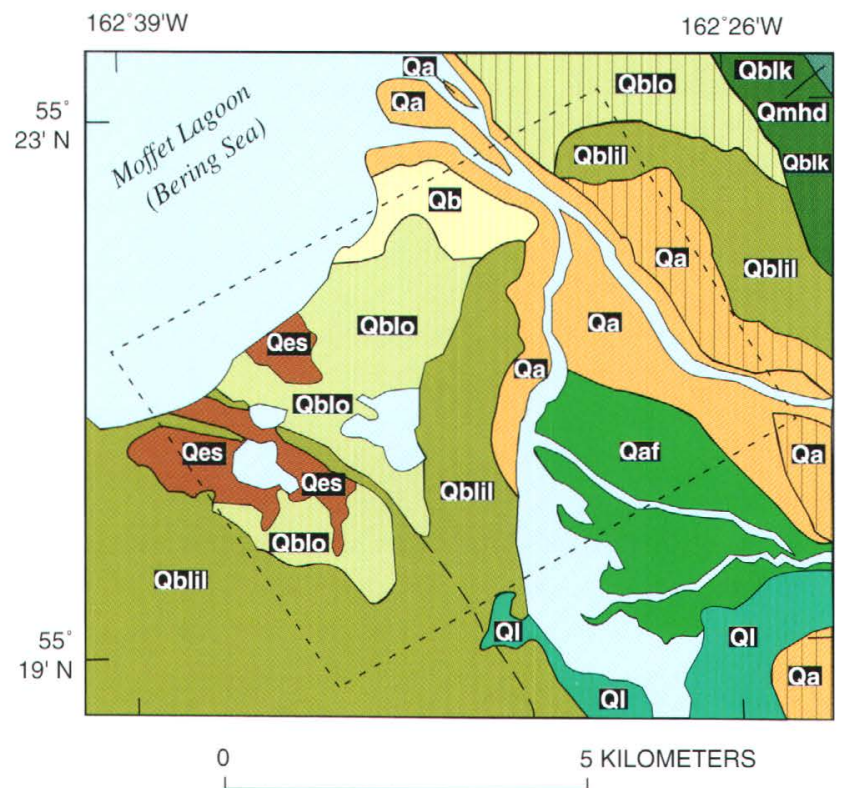

EXPLANATION

\section{Glacial deposits \\ Brooks Lake Glaciation}

\begin{tabular}{|c|c|}
\hline Qmhd & Drift \\
\hline Qblo & Outwash, undivided \\
\hline बbाt & Iliamna advance end moraine \\
\hline Qblk & Kvichak advance end moraine \\
\hline & Vertical lines indicate areas of marine \\
\hline & Water \\
\hline & $\begin{array}{l}\text { Dotted line outline is } \\
\text { area of figure } 4 A\end{array}$ \\
\hline
\end{tabular}

Figure 4B. Section of geologic map at mouth of Joshua Green River (Wilson and others, 1997) showing geologic interpretation of the area of the photograph. Approximate area of photograph is dotted outline on map. Scale of map is about 1:125,000.

this moraine. This could indicate that the ridge is either a recessional moraine of the Iliamna advance or less likely a moraine of the Newhalen advance. At Cold Bay, the morphol- ogy of the Iliamna moraine suggests a multi-stage event and the Newhalen moraines show a distinctively less weathered form than the Iliamna moraines. In the Cathedral Valley, we do not have the information to resolve which glacial event, if any, these arcuate ridges might be associated with; on the basis of their apparent character on air photos, we suggest that they are most likely associated with the Iliamna advance. Whatever its age, the deposit at the valley junction has been eroded by large quantities of water flowing down the main valley. This should be no surprise because the head of the main valley has post-glacial lava flows of at least two ages. These might have catastrophically melted any ice or snow accumulated, producing jökulhlaups. To the west of this moraine arc in the valley of the west fork of Cathedral Valley, which originates under the Aghileen Pinnacles (see fig. 2), is a deposit that is strongly suggestive of a moraine or debris flow. It served at one point as a dam, backing up an ephemeral large lake in the west fork valley. In the east fork of Cathedral Valley, upstream of this deposit, are young, Holocene lava flows from Little Pavlof Volcano in the adjacent Port Moller 1:250,000-scale quadrangle. If this deposit in the west fork valley is a moraine, it is most likely derived from a tributary glacier during the Iliamna advance.

Many parts of the Cold Bay region record evidence of a highstand of the sea about $15 \mathrm{~m}$ above present sea level. Particularly well preserved are shorelines in Joshua Green River valley. Evidence of this highstand can be found as terraces in much of the coastal area, where deposits older than Newhalen advance glacial deposits are affected. Similar terraces are well known northward along the Alaska Peninsula. In the vicinity of Cold Bay, these terraces are present at roughly the same elevation on both the Pacific and Bering Sea coasts; to the north on the Alaska Peninsula, for example in the Chignik and Wide Bay areas and the Port Moller 1:250,000-scale quadrangle, terrace elevations gradually increase from west to east, indicating differential uplift (Detterman, 1986, p. 156). We believe that there are isostatic, eustatic, and tectonic components to this uplift record.

The lack of evidence for latest Pleistocene (post-Iliamna advance) and Holocene glaciation on the northeast side of the buttress indicates that additional volcanic event(s) may have taken place. In addition to the lava flows on Cathedral Creek, the head of the Middle Fork of Joshua Green River canyon contains a lava flow and a small debris flow. Morphological evidence suggests that the Joshua Green River valley has had large discharges of water which we attribute in part to volcanic activity melting the glaciers that had existed (and exist today) on the volcanoes at the head of the valley in post-Iliamna time. Pavlof Volcano, Pavlof Sister, Little Pavlof, and Mt. Hague on the northeast side of the buttress all developed since the formation of Emmons caldera and are known to have had many Holocene and historic eruptions; their ash and ash-flow deposits are distributed on the northeast side of the buttress. These volcanic deposits could be covering the late Pleistocene and Holocene glacial deposits, or, more likely in our opinion, the active volcanism may have prevented the development of glaciers in this part of the buttress. 


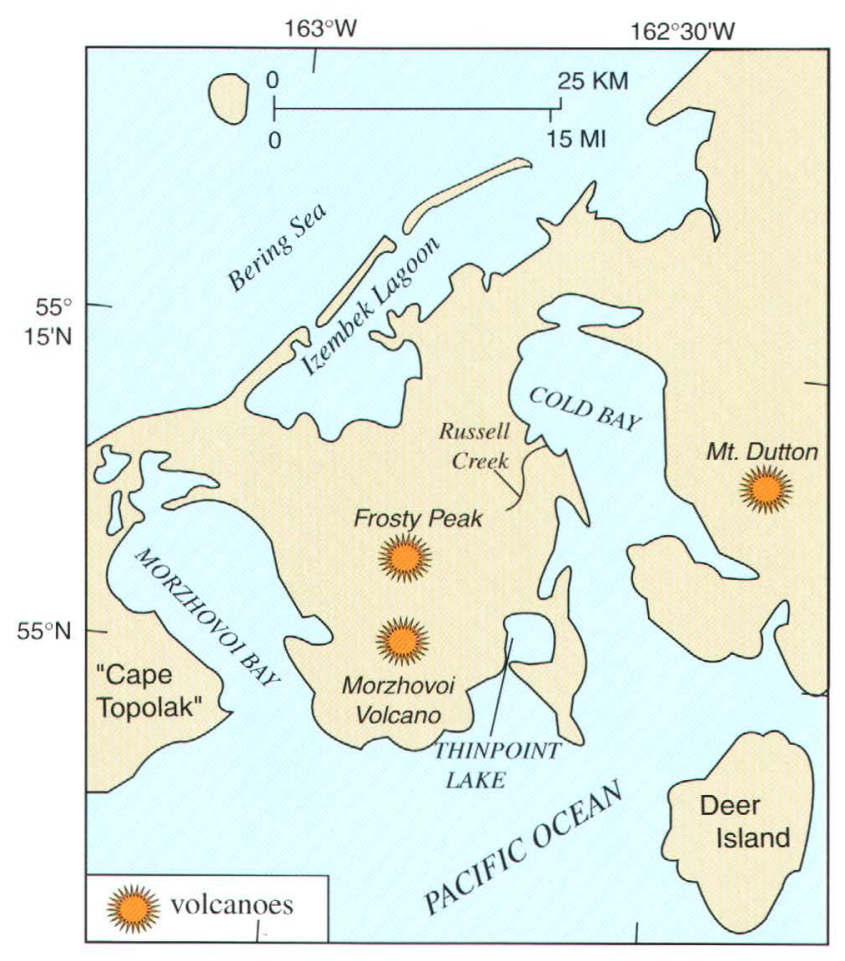

Figure 5. Index map showing location of the Morzhovoi Volcano and Frosty Peak buttress region.

\section{Morzhovoi Volcano and Frosty Peak Buttress Region}

The Morzhovoi Volcano and Frosty Peak buttress region (fig. 5) consists in large part of ancestral Morzhovoi Volcano. Located between present-day Cold and Morzhovoi Bays south of Frosty Peak (fig. 1), it has probably been an island volcanic center during much of the Quaternary. Extensive glaciation has removed much of the original volcanic edifice, and only remnant flows from the volcano remain. Waldron (1961) recognized that these remnant flows represented a large volcanic center, which he termed Morzhovoi Volcano.

Underlying the volcanic flows of Morzhovoi Volcano is the type locality and a key reference section of the late Miocene Tachilni Formation (Detterman and others, 1996). Both of these sections are exposed on the south flank of the volcanic pile. The Tachilni Formation consists of marine and nonmarine sandstone, mudstone, and conglomerate having a chiefly volcanic provenance. It is richly fossiliferous and the fossils indicate shallow water deposition (Detterman and others, 1996). Unconformably overlying the Tachilni are volcanic rocks that grade upward into the Morzhovoi volcanic pile.

Northwest of the volcanic center, the Morzhovoi Bay Formation of Funk (1973) is exposed in a sea-cliff exposure along the Bering Sea coast at the head of Morzhovoi Bay. Funk $(1973,1976)$ also mapped areas of outcrop of the Morzhovoi Bay Formation in the northeast part of the Cold Bay 1:250,000-scale quadrangle. Divided into two units, the lower unit consists of 10 to $12 \mathrm{~m}$ of well-compacted, dark grayish-brown till, containing numerous angular boulders having minor oxidation rinds. The upper unit consists of moderately well sorted, stratified, and consolidated sand and gravel or silt and clay. Funk interpreted these deposits in the Cold Bay region to be glaciomarine deposits that had not been subaerially exposed on the basis of the minor oxidation, lack of weathering profiles, and the presence of an upper stratified member. We agree with his interpretation of the deposits at the head of Morzhovoi Bay; however, because of the lack of weathering we suggest that rather than the Mak Hill it should be assigned to the Kvichak advance of the Brooks Lake drift. Only in the area north of the Aghileen Pinnacles did Funk (1973) map any deposits showing surface expression of his Morzhovoi Bay unit, and it is not apparent that he actually visited this area. Nonetheless, we concur with his assignment of some of these rocks north of the Aghileen Pinnacles to an older glacial event, which we correlate with the Mak Hill event as described in the section on the Emmons Buttress above.

Waldron (1961) suggested an early to middle Quaternary history for Morzhovoi Volcano, leading to caldera formation (see table 3 ). A poorly reproducible and therefore unpublished preliminary $\mathrm{K}$-Ar age determination on a flow high in the section (Nora Shew and F.H. Wilson, unpub. data) suggests an age of less than $1 \mathrm{Ma}$, which is consistent with the timing Waldron suggested. In spite of the extensive glaciation of the volcanic center, glacial deposits of any age are uncommon in the immediate vicinity of this volcano. Lacustrine or marine deposits are present in three of the south-facing, glacially carved valleys of the remnant Morzhovoi Volcano behind or landward of beach dune deposits. We believe that water bodies were impounded in these lower valleys by shelf ice during one or more advances of the Brooks Lake glaciation. By inference then, Morzhovoi Volcano must have been glaciated early during the Brooks Lake glaciation or before. Small moraines are located in two of the south-facing valleys of Morzhovoi Volcano, one of which also has evidence of flooding. These moraines are probably correlative with one of the younger Brooks Lake advances and the Russell Creek alpine advances and are not Neoglacial moraines because they extend to much lower elevation (less than $30 \mathrm{~m}$ and $75 \mathrm{~m}$ ) than Neoglacial moraines. The latter typically do not extend much below 300 $m$ in elevation.

The north crater of Frosty Peak Volcano (fig. 6) is ice filled and has a glacier draining it to the west. Previous mapping (Waldron, 1961; Funk, 1973, 1976; Brophy, 1984) had shown extensive glacial deposits extending radially from Frosty Volcano. In the valley draining the north crater of Frosty Volcano, these glacial deposits were mapped as extending virtually to the coast of Morzhovoi Bay. However, we found that this valley below the glacier and its Neoglacial moraine had been largely filled by a clast-rich, hydrothermally altered, volcanic debris flow derived from the north crater of Frosty Volcano that may extend to within $1 \mathrm{~km}$ of the coast of Morzhovoi Bay. Late Wisconsin glacial deposits are lacking or at least buried by volcanic debris-flow deposits in much of this valley. We were unable to determine if the debris-flow 
deposits from the North Crater overlie drift of Funk's (1973) mapped Russell Creek (Iliuk) age in the valley or are overlain by drift. Air photo interpretation suggests that Russell Creek morainal deposits are located at the distal end of the debrisflow deposits, constraining the age of the eruption to younger than the drift. A radiocarbon date on peat of $6,700 \mathrm{yr}$ B.P. (GX2788, Wilson and others, 1997; table 1), reported as coming from either lacustrine deposits (Funk, 1973) or outwash (Funk, 1976), is interpreted as a minimum age associated with these glacial deposits. Funk (1973) did not describe the section in which this radiocarbon sample was collected nor locate it precisely because only crude topographic maps were available in the area in the early 1970's. Therefore, it is not possible to determine if the dated peat deposits overlie the debris-flow deposits or if the debris-flow deposits extend as far as the site of the sample. Funk (written commun., 1997) was not able to clarify the nature of the deposits from which the sample was collected and therefore this radiocarbon date is not useful in constraining the age of the debris flow. Funk's (1973) Frosty drift is derived from the present glacier in the North Crater, and he suggests it is of Neoglacial age. The Neoglacial moraine extends less than $1 \mathrm{~km}$ down valley from the present glacier as shown on the published 1:63,360-scale topographic map that was compiled from 1987 aerial photography. By 1996, the glacier had receded farther up-valley. The age of the Russell Creek drift has been considered latest Pleistocene or earliest Holocene (Detterman, 1986), and, if this unit really is present at the distal end of the valley, it constrains the age of the crater-forming eruption to the early Holocene or later.

We believe that Frosty Volcano is largely a latest Wisconsin and Holocene constructive feature (see figures 7 and 8 and Wilson and others, 1997) based on the pattern of Brooks Lake glacial moraines near Frosty Volcano. This is in contrast to Waldron's (1961) interpretation that the caldera-forming eruption of the north caldera of Frosty Volcano was of Pleistocene age. Our mapping indicates that the timing of the caldera-

Table 3. Provisional Quaternary history of the Morzhovoi Volcano and Frosty Peak buttress region.

[See text for explanation]

\begin{tabular}{|c|c|c|}
\hline Event & Suggested age & Calibrated radiocarbon age \\
\hline $\begin{array}{l}\text { Morainal deposits at Frosty Peak, both north and south } \\
\text { craters }\end{array}$ & Neoglacial & $\begin{array}{l}\text { 1,060 yr. B.P. } \\
\text { TDS-96-09A } \\
\text { (Beta-96827) }\end{array}$ \\
\hline $\begin{array}{l}\text { Emplacement of summit cone-building volcanic rocks of } \\
\text { south peak }\end{array}$ & Holocene(?) & \\
\hline \multicolumn{3}{|l|}{$\begin{array}{l}\text { Eruption of ash flow from Frosty Peak (south crater). Flow } \\
\text { ponded behind earlier lava flow }\end{array}$} \\
\hline $\begin{array}{l}\text { Development of North Crater and emplacement of volcanic } \\
\text { debris flow deposits west of Frosty Volcano }\end{array}$ & early Holocene(?) & \\
\hline $\begin{array}{l}\text { Tephra beds ("Funk [Fisher] ash") in Cold Bay area lying } \\
\text { stratigraphically above moraines identified as Newhalen } \\
\text { and Russell Creek }\end{array}$ & post-Pleistocene $9 \mathrm{ka}$ & 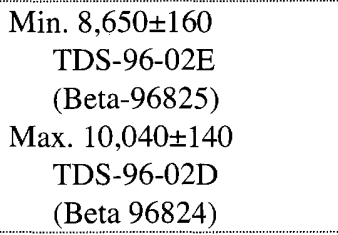 \\
\hline $\begin{array}{l}\text { Highstand of the sea, roughly } 16 \mathrm{~m} \text { above MSL (Jordan, } \\
\text { 1997) }\end{array}$ & $\begin{array}{l}\text { late Wisconsin or early } \\
\text { Holocene age }\end{array}$ & \\
\hline $\begin{array}{l}\text { Eruption of massive lava flow from Frosty Peak; flow may } \\
\text { have erupted in an icefield }\end{array}$ & late(?) Wisconsin & \\
\hline $\begin{array}{l}\text { Russell Creek alpine drift and Brooks Lake drift, Iliuk } \\
\text { advance. Iliuk advance deposits may form a submerged } \\
\text { ridge at mouth of Cold Bay (see Wilson and others (1997) }\end{array}$ & late Wisconsin & \\
\hline $\begin{array}{l}\text { Brooks Lake drift, Newhalen advance glacial deposits found } \\
\text { on west shore of Cold Bay }\end{array}$ & late Wisconsin age & \\
\hline $\begin{array}{l}\text { Brooks Lake drift, Iliamna advance; forms bulk of glacial } \\
\text { deposits north of Morzhovoi Bay and Cold Bay }\end{array}$ & Wisconsin age & \\
\hline $\begin{array}{l}\text { Brooks Lake drift, Kvichak advance; outer rim of glacial } \\
\text { deposits north of Morzhovoi Bay and Cold Bay }\end{array}$ & Wisconsin age & \\
\hline Glaciomarine(?) deposits north of Morzhovoi Bay & $\begin{array}{l}\text { Wisconsin } \\
\text { or earlier age }\end{array}$ & \\
\hline Eruption of ancestral Morzhovoi Volcano & about $1 \mathrm{Ma}$ & \\
\hline
\end{tabular}




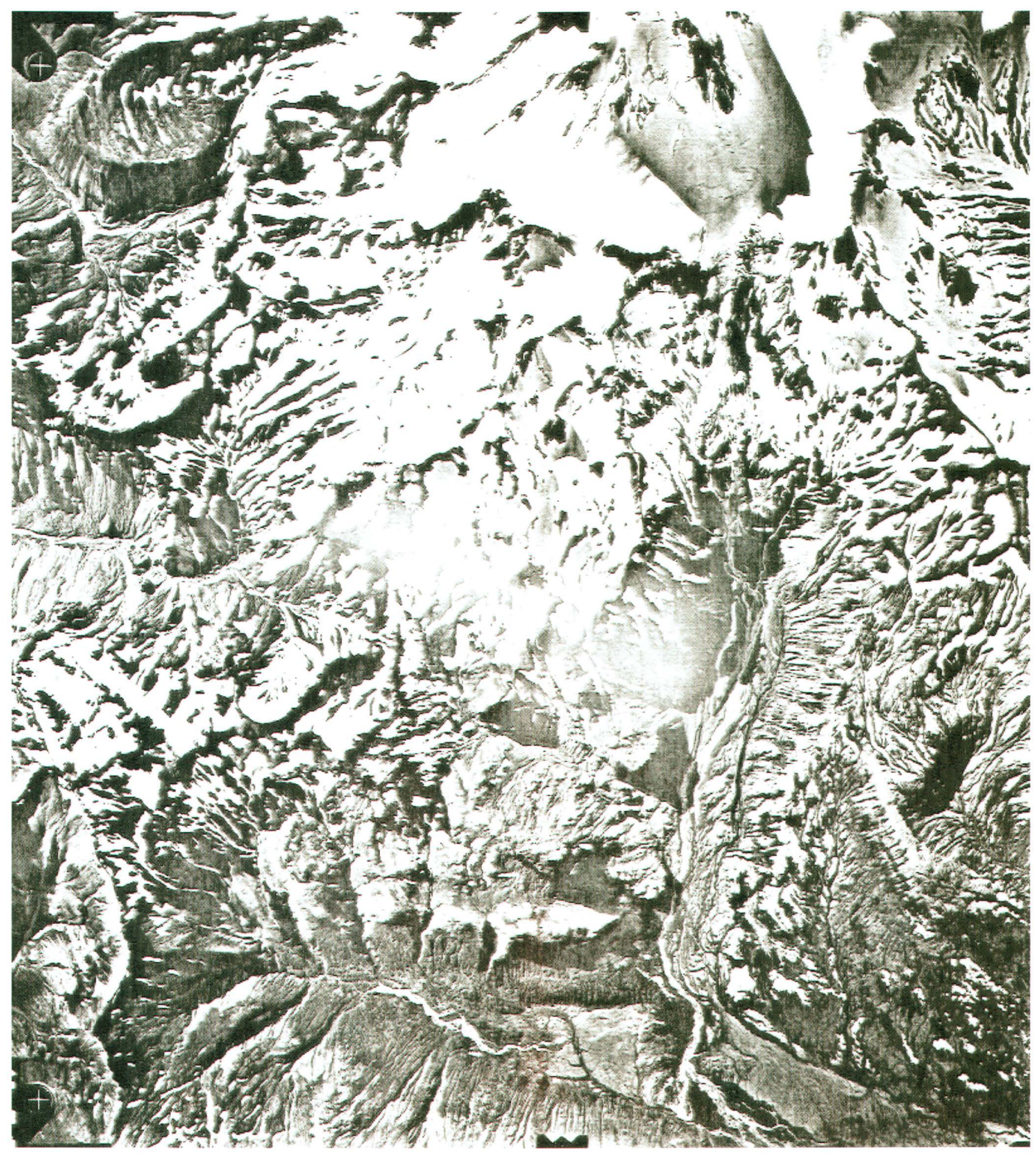

Figure 6A. Aerial photograph showing the southern flank of Frosty Volcano. North is diagonal across the picture, pointing to the upper left. In the upper center of the photograph, the south peak of Frosty Volcano is visible, composed of the "volcanic rocks of the summit cone" as mapped by Waldron (1961). The rocks fill an older crater, whose rim is visible surrounding the summit cone. In the upper left corner, the thick ponded flow discussed in the text is visible. Just below (southeast) of this flow are ash-flow deposits ponded behind it. The same ash flow came down the linear valley running down the right center of the photograph. In this valley, the ash flow continued to the right off the photograph, reaching the coast. Unfortunately, thin cloud cover obscures some of the image as does the poor resolution of the reproduction; however, just visible at the head of the linear valley is Neoglacial moraine extending about $1 \mathrm{~km}$ from the crater. Photograph 11-5, taken July 26,1987 , for the U.S. Geological Survey. 


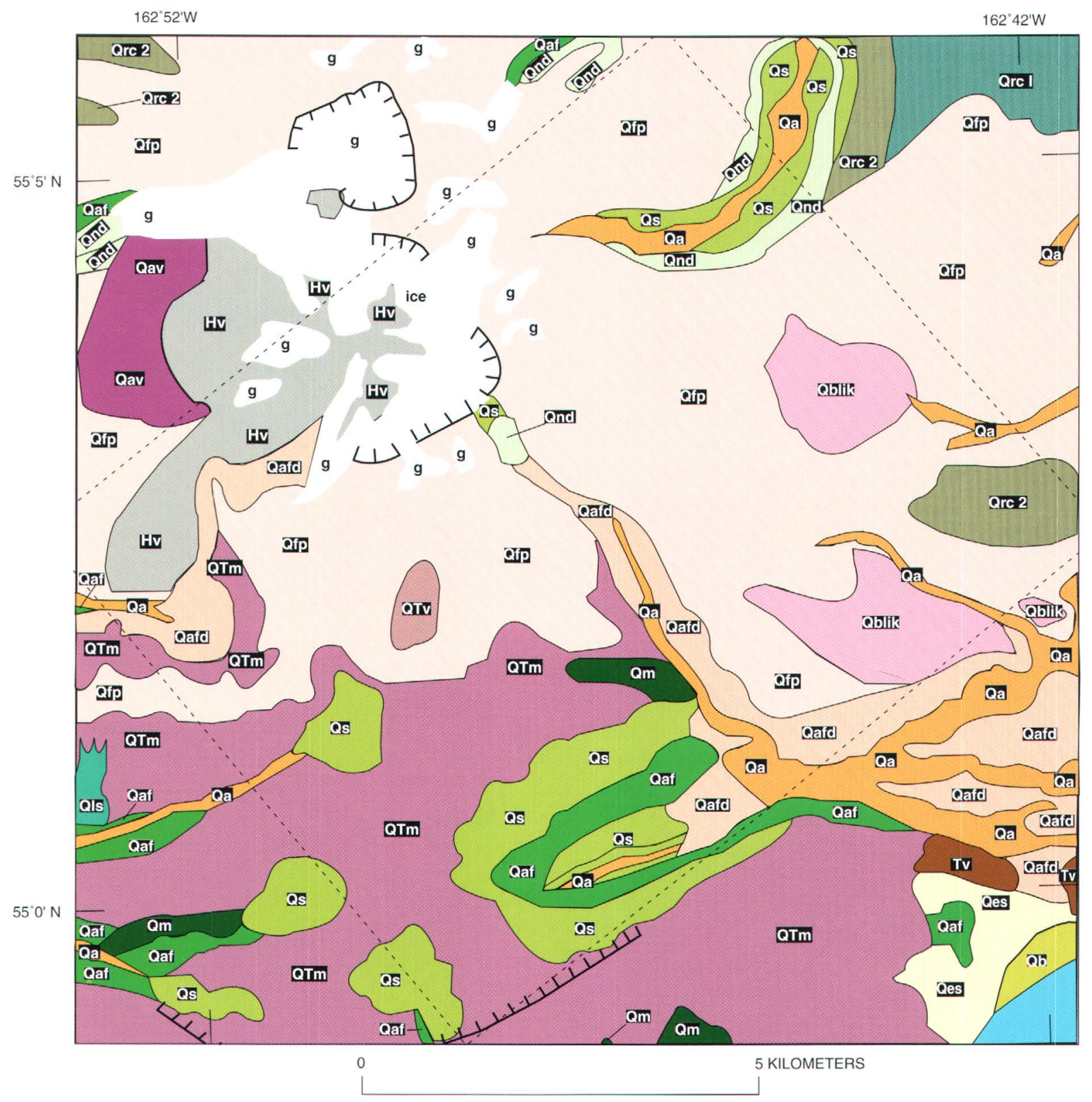

\section{EXPLANATION}

\begin{tabular}{|c|c|}
\hline g & glacier ice \\
\hline QS & Undivided surficial deposits \\
\hline Qa & Alluvial deposits \\
\hline Qafi & Alluvial fan deposits \\
\hline का & Beach deposits \\
\hline Qes & Estuarine deposits \\
\hline QIs & Landslide deposits \\
\hline
\end{tabular}

Glacial deposits

Qm Moraine, undivided

and Neoglacial moraine deposits

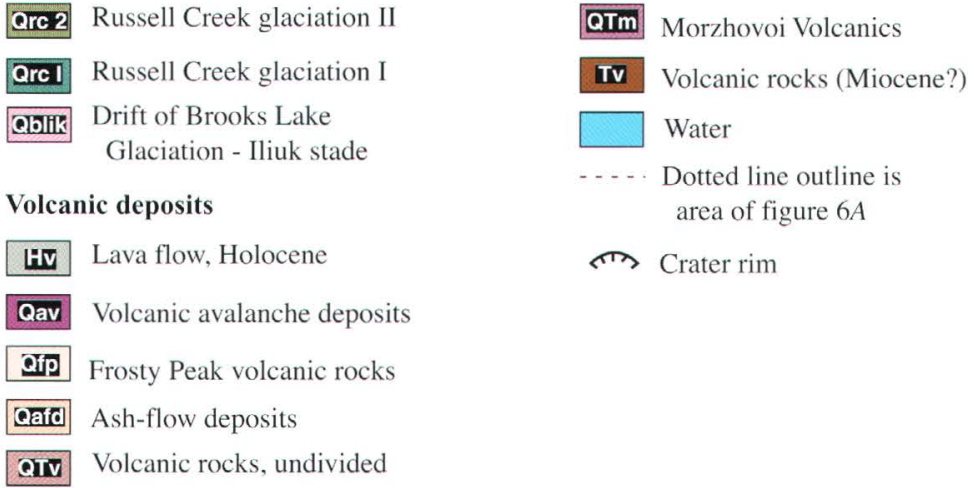

Figure 6B. Section of geologic map (Wilson and others, 1997) showing geologic interpretation of the area of the photograph. Approximate area of photograph is dotted outline on map. Scale of map is about 1:125,000. 
forming eruption is latest Pleistocene or Holocene, most likely between the last Wisconsin glaciation and Neoglaciation for the following reasons. The Cold Bay moraine of Funk (1973) includes deposits largely of the Kvichak and Iliamna advances and to much less extent the Newhalen advance of the Brooks Lake drift; these glacial deposits show no influence of Frosty Volcano. Yet moraines derived from Frosty Volcano (the Russell Creek drift of Funk, 1973) extend over these older morainal ridges, whereas, elsewhere, glacial advances younger than the Iliamna and Kvichak advances are much less extensive than the older moraines. As the Iliuk advance of the Brooks Lake drift was one of the least extensive (Ukak advance? of Pinney and Beget, 1991, is possibly the youngest and least extensive), we found it disconcerting that Russell Creek drift from Frosty Peak overlaps the drift of early Brooks Lake age (Cold Bay moraine of Funk, 1973). From this relationship, we infer that Frosty Volcano was constructed largely after the Iliamna advance but early enough to become an accumulation zone for later (younger) glacial episodes. Therefore, we have concluded that Frosty Peak (volcano) did not exist during most of the Brooks Lake glaciation.

The uppermost, southern part of Frosty Volcano (the actual Frosty Peak) is a late Wisconsin(?) and Holocene constructive feature, largely filling a preexisting crater. The unit Waldron (1961) mapped as "volcanic rocks of the summit cone" nearly fills this crater. Largely covered today by perennial snow and ice, these volcanic rocks show no evidence of extensive glaciation, implying post-glacial emplacement. Off the southwestern flank of the south peak (see fig. $6 B$ ), a lava flow (labeled "Hv") was erupted that did not flow more than $3 \mathrm{~km}$ from its source, yet it is nearly $300 \mathrm{~m}$ thick at its distal end. Its form, which is a lobate ridge extending into an exist- ing glaciated valley, indicates that it may have been erupted into an icefield and ponded, similar to the flows derived from the 1983 eruption of Veniaminof Volcano (Yount and others, 1985). On the opposite valley wall from this flow, a similar, more weathered - and presumably older-flow, shown as part of unit QTm, forms a prominent projection from the valley wall, and together these flows nearly dam the initially south draining, glacially carved valley. At some later time (after melting of the ice and, therefore, we believe in Holocene time) an eruption yielding an ash flow came from Frosty Peak (shown as unit Qafd near Frosty Peak, Wilson and others, 1997). To the southwest, this ash flow was largely trapped and dammed behind the above-mentioned lava flows, forming a thick deposit that has since been moderately dissected by fluvial erosion. In the narrow valley draining Frosty Peak to the southeast, pyroclastic flows from the same eruption also traveled down-valley and spread widely, possibly reaching the west shore of Thinpoint Lake (shown as Thinpoint Lagoon on older maps). In the uppermost part of this narrow valley is a Neoglacial(?) moraine, probably indicating that the eruption did not occur in late Holocene time. Because no distinctive source area for the pyroclastic flows is apparent, the implication is that the summit-cone-building flows of Frosty Peak were erupted after this explosive event. However, the relatively fresh character of the ash flows is evidence that they are definitely younger than the previously described debris flow deposits emanating from the north crater. These relatively extensive Holocene(?) volcanic deposits on the south and west flanks of Frosty Volcano (areas previous workers had apparently not reached) indicate that previous inferences by Waldron (1961), Brophy (1984), and others about the history of Frosty Volcano may well be incorrect.

Table 4. Provisional Quaternary history of the Ikatan Peninsula and Unimak Island region.

[See text for explanation]

\begin{tabular}{|c|c|}
\hline Event & Suggested age \\
\hline $\begin{array}{l}\text { Development of tombolo connecting former Ikatan Island and Unimak Island, } \\
\text { creating Otter Cove }\end{array}$ & post-1850 A.D. \\
\hline $\begin{array}{l}\text { Deposition of ash over a wide area in the vicinity of Otter Cove from volcanic } \\
\text { eruption of Roundtop and Isanotski Peaks }\end{array}$ & March 10,1825 \\
\hline Highstand of the sea, roughly $16 \mathrm{~m}$ above MSL (Jordan, 1997) & $\begin{array}{l}\text { late Wisconsin or } \\
\text { early Holocene }\end{array}$ \\
\hline Brooks Lake drift, Iliuk advance, not recognized with certainty & late Wisconsin \\
\hline $\begin{array}{l}\text { Brooks Lake drift, Newhalen advance, forms fragmentary morainal arc north of } \\
\text { Roundtop }\end{array}$ & late Wisconsin \\
\hline $\begin{array}{l}\text { Brooks Lake drift, Iliamna advance, forms large arcuate moraines north of } \\
\text { Roundtop and Isanotski Peaks }\end{array}$ & Wisconsin \\
\hline $\begin{array}{l}\text { Brooks Lake drift, Kvichak advance, glacial deposits north of Roundtop and } \\
\text { Isanotski Peaks }\end{array}$ & Wisconsin \\
\hline Mak Hill(?) glacial episode, moraines along northeast coast of Unimak Island & pre-Wisconsin \\
\hline
\end{tabular}


Ikatan Peninsula and Unimak Island Region

Unimak Island (fig. 7) appears to contain many of the basic Quaternary geologic units seen elsewhere in the Cold Bay region. The easternmost of the Aleutian Islands, it is dominated by late Pleistocene(?) and Holocene volcanic centers. No glacial deposits other than a few Neoglacial moraines were observed on the Pacific coast side of the island or on the Ikatan Peninsula. At low elevation in a few areas, marine terraces are apparent near the Pacific coast, indicating some relative uplift. On the north or Bering Sea side of Unimak Island, extensive glacial deposits are present in the lowlands. Deposits from shelf glaciers that overrode the Ikatan Peninsula and adjacent Alaska Peninsula are found on the extreme northeast of the island. Farther west, the glacial deposits were likely derived from the Roundtop and Isanotski Peaks volcanic centers. At the extreme western edge of the map area, no glacial deposits were recognized that were derived from Shishaldin Volcano, supporting the contention of Fournelle $(1988,1990)$ that it is largely a late Pleistocene and Holocene edifice. Alternatively, extensive volcanic pyroclastic and debris deposits on the north side of Shishaldin Volcano may overlie glacial deposits that might correlate with the Brooks Lake drift.

Deposits of Holocene volcanic eruptions are apparent on Unimak Island near each of the three volcanoes that are wholly or partly in the map area of Wilson and others (1997). A large expanse of nonvegetated volcanic ash covers valley floors west of Otter Cove on the southeast part of the island. These deposits are extensive enough that we were unable to distinguish their source other than it must have been in the vicinity of Roundtop and Isanotski Peaks. Veniaminov (1840, p. 18) reports a volcanic eruption on March 10, 1825, that is probably the source of this ash. He says, “... the northeast range of Unimak exploded in five or more places and over a large area ..." and goes on to say the ash covered the end of the Alaska Peninsula to a depth of several inches. In part because of the extensive distribution of the deposits, and in part because of Veniaminov's (1840) report, we believe that these deposits may represent eruptions from both the Roundtop and Isanotski Peaks volcanic centers. In contrast to the deposits on their south flanks, recent volcanic debris is not as apparent on the north flanks of these volcanoes, where older glacial deposits of Brooks Lake age are preserved.

Russian maps dating from the mid-1800's show a passage between Ikatan Bay and Otter Cove (fig. 7, or see Veniaminov, 1840, p. 107). Chuck Martinson (oral commun., 1990), a local resident, has reported speaking in the 1950's with False Pass village elders who remembered paddling through this passage during their youth. The two parts of the island were connected by the present tombolo sometime in the late 1800's or early in the 1900's. Fournelle (1988, p. 29-30) also reports similar evidence from Finch (1934) about the historically recent joining of the Ikatan Peninsula to Unimak Island and attributes the joining to uplift on the order of $3 \mathrm{~m}$ in $200 \mathrm{yr}$ (or about $150 \mathrm{~m}$ in Holocene time). Another suggestion is that this change could have been the result of a reworking of deposits from the 1825 volcanic eruption. However, there is little confirming information.

\section{Discussion}

The glaciomarine deposits of the Morzhovoi Bay Formation of Funk (1973) were correlated by Detterman (1986) with Mak Hill drift of early Wisconsin(?) age on the basis of their position, land forms, and weathering characteristics in the northeastern part of the Cold Bay region. We have revised Funk's (1973) mapping in the northeast part of the Cold Bay region, extending the mapping of Quaternary glacial units northeastward toward the adjoining Port Moller region. We examined the sea-cliff exposures reported by Funk on the Bering Sea at the head of Morzhovoi Bay and remain divided over their nature and correlation. These exposures are moderately indurated, locally bedded, marine deposits and do not match the lithologic descriptions of potentially correlative units elsewhere on the Alaska Peninsula. As a unique and geographically isolated exposure, we are not able to establish the position of this particular outcrop sequence in our suggested stratigraphy.

The 75- to 90-m highstand of the sea and the marine erosion that affected the Johnston Hill and lower elevation parts of the Mak Hill moraines as described for the Emmons buttress region makes it difficult to answer the question of whether the Johnston Hill drift represents a separate glacial event or is just an earlier advance of the Mak Hill event. It is not possible with our data to resolve the issue of the distinction of these deposits that was raised by Kaufman and others (1995) on the northern Alaska Peninsula. However, despite the isostatic vagaries of the Alaska Peninsula, we infer from the highstand of the sea that there was a significant warming postdating the Johnston Hill and Mak Hill drifts, more like an interglacial period than an interstadial period. In our experience in the adjacent Port Moller 1:250,000-scale quadrangle and elsewhere on the Alaska Peninsula, there is evidence, particularly in marine terrace levels and uplifted sea caves, that shows the Alaska Peninsula has long been undergoing relative uplift. The uplift has proceeded at a greater rate on the Pacific Ocean side than on the Bering Sea side. Undoubtedly, the sea-level highstands documented here flooded the lower levels of the Johnston Hill and Mak Hill glacial deposits on lower Cathedral River. The significance of the inundation in terms of Quaternary worldwide levels is problematical as the Alaska Peninsula has a complex history of isostatic and tectonic instability (see for example, Winslow and Johnson, 1988, 1989a, 1989b) in part in response to rebound after the melting of the continental shelf glaciers and in part as a response to tectonic adjustments related to the Aleutian Trench and magmatic arc.

We suggest that the earliest two Brooks Lake advances are of early Wisconsin age, rather than the generally accepted late Wisconsin age. Nowhere on the Alaska Peninsula are these glacial advances unequivocally dated. The only reported ages on these older advances are both approximately 26,000 yr B.P. (Stilwell and Kaufman, 1996; Mann and Peteet, 1994) on deposits that have a tenuous relationship to the moraines they purport to date (Kvichak and "Naknek," respectively). In 


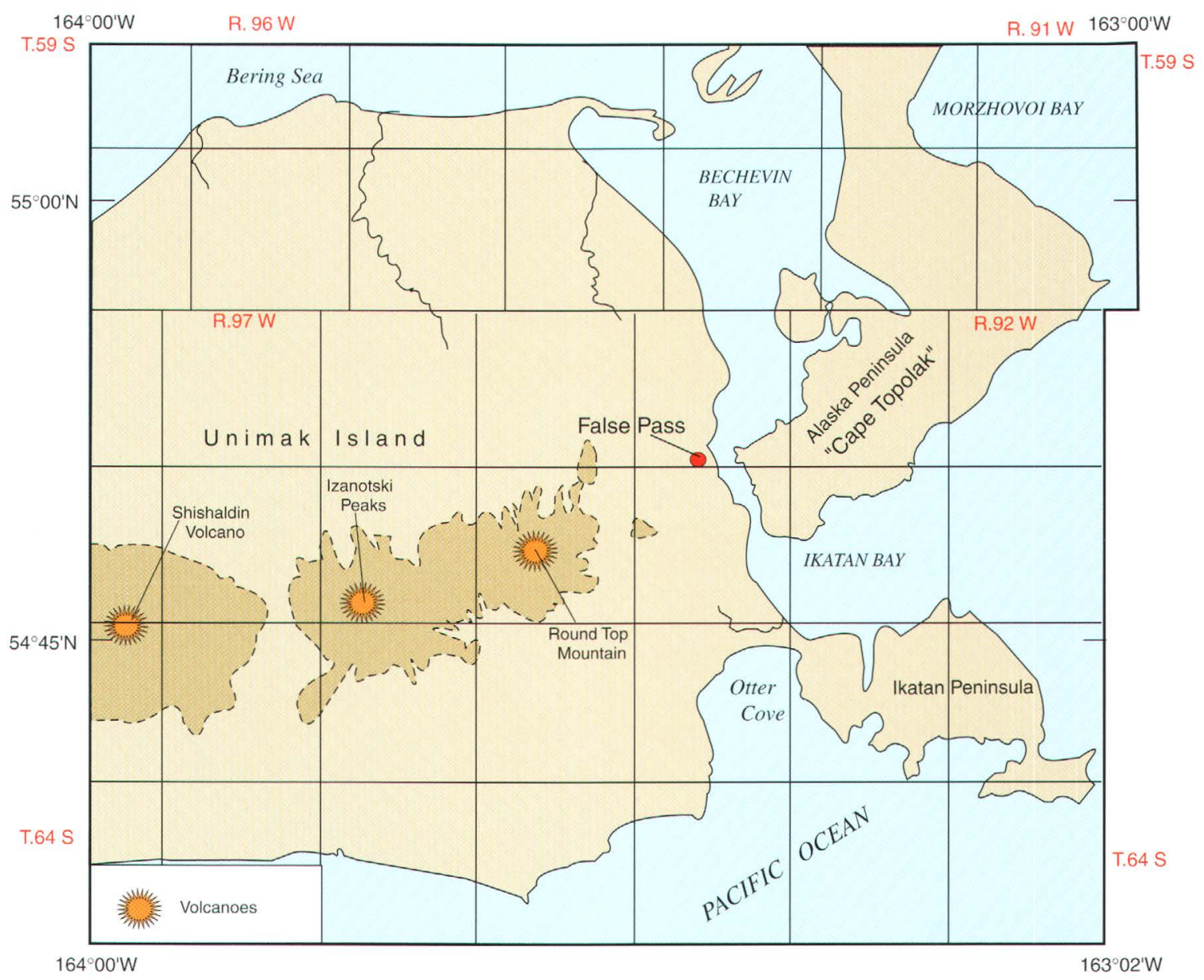

Figure 7. Ikatan Peninsula and Unimak Island region.

both cases, the dated material came from outwash deposits collected down stream of the moraines. However, that outwash could just as easily be associated with later events and in the case of the Kvichak date, the collected sample was $20 \mathrm{~km}$ distant from the moraine it is used to date. There are distinctive weathering and morphological differences between moraines assigned to the Kvichak and Iliamna advances and those of the later Brooks Lake advances. There is also evidence for significant volcanic activity including construction of the Pavlof group, Frosty Peak, and Shishaldin Volcanoes. Together, these lines of evidence suggest a significant time gap between the deposition of the two groups of glacial deposits.

On the Alaska Peninsula, a number of schemes have been proposed to describe the stratigraphy of the Quaternary units. Funk (1973) and Detterman (1986) (table 1) proposed schemes that are applicable to the Cold Bay region, where the youngest Pleistocene (Wisconsin) glacial deposits were assigned to the Brooks Lake drift. Divided by Detterman (1986) into the deposits of four advances, the Russell Creek drift of Funk (1973) was considered equivalent to the Iliuk advance, the youngest of the sequence. Work in the Katmai region (Pinney and Beget, 1991; Pinney, 1993) suggests the existence of a fifth advance, named the Ukak advance. This advance, mapped as part of the Iliuk advance by Riehle and Detterman (1993) may be of early Holocene age. Additional mapping and dating in the Katmai region by Mann and Peteet (1994) and Stilwell and Kaufman (1996) suggest an alternative interpretation for the northern Alaska Peninsula (see table 1). Based on our mapping and interpretations, we suggest yet another modification of the proposed stratigraphy as shown in table 1 .

In the Cold Bay region, we do not have sufficient evidence to determine whether deposits of the Ukak advance of Pinney and Beget (1991) and Pinney (1993) exist or to distinguish between the Iliuk (Russell Creek drift) and Ukak advances. In the vicinity of Cold Bay, we were able only with uncertainty to resolve the Cold Bay Formation of Funk (1973) into the deposits of the Kvichak, Iliamna, and Newhalen(?) advances of the Brooks Lake drift. However, with distance from Cold Bay, for example in the Cathedral River valley, distinctive units are more apparent. Even so, in the Joshua Green River valley, the three authors (Wilson, Weber, and Dochat) who focused on the Quaternary units of the revised 
geologic map (Wilson and others, 1997) were not able to agree on the correlation of the glacial deposits. Weber and Wilson interpret the mapped deposits in the Joshua Green Valley as alpine glacial advances that correlate with the Iliamna and Kvichak advances of the Brooks Lake shelf drift in this area. In our vision, ice from the shelf ice-accumulation zone locally overtopped low passes on the Emmons buttress and joined with existing alpine ice masses to produce the large "alpine" glaciers. In the area northwest of Cold Bay where Iliamna moraine deposited by the shelf glacier is adjacent to that of the second alpine moraine, Wilson and Weber interpret the evidence as indicating coeval ice masses where the larger shelf glacier caused a northward deflection of the alpine glacier flow. Dochat, in contrast, interprets the evidence to show that the Joshua Green moraines are purely alpine advances of early to middle Wisconsin age, predating the Brooks Lake advances. In her interpretation, these alpine glaciers had retreated due to loss of source as sea level fell, the Bering Sea floor emerged, and shelf glaciers built and advanced (Dochat, 1997). As the shelf glaciers advanced, they overrode and deformed the much earlier alpine morainal deposits upon contact, yielding an appearance that the alpine glaciers had flowed northward. However, we consider this scenario unlikely because the uniform weathering and surface characteristics of the alpine and shelf-glacier morainal deposits and because the regular and even arcuate form of the Joshua Green moraines do not indicate post-depositional deformation.

Previous workers (Waldron, 1961; Funk, 1973, 1976; Brophy, 1984) considered Frosty Volcano to have been dormant during Holocene time. For Frosty Volcano, Waldron (1961) inferred two episodes of volcanism widely separated in time. The first may have been coeval with some stage of the eruption of Morzhovoi Volcano, from either a parasitic cone or a new vent. Waldron (1961, p. 694) suggested that Frosty Volcano was largely constructed prior to late Wisconsin time because extensive glacial deposits were derived from it and no volcanic products were mapped on top of these glacial deposits. These glacial deposits were later mapped as the Russell Creek drift by Funk $(1973,1976)$. Based on limited age control, Funk suggested that the Russell Creek moraines were of latest Wisconsin age. Brophy (1984) largely accepted Waldron's and Funk's mapping of Frosty Volcano, essentially reproducing Waldron's map in his report. Detterman (1986) accepted the latest Wisconsin age of Funk (1976) and correlated the Russell Creek drift with the Iliuk advance of the Brooks Lake drift, best known from the northern part of the Alaska Peninsula but mapped as far southwest as the adjacent Port Moller quadrangle (F.R. Weber, R.L. Detterman, and F.H. Wilson, unpub. data, 1988). Our mapping and radiocarbon dating (Wilson and others, 1997), in conjunction with a reinterpretation of the mapping of Funk (1973) indicate a history of multiple Holocene (Neoglacial) glacial advances in the vicinity of Frosty Peak Volcano. In addition, in many other areas of the map we have mapped undated deposits of presumed Neoglacial age, in some cases mapping more than one moraine to a valley. These deposits typically do not extend far $(1 \mathrm{~km}$ or less) from local cirques, except near Frosty Peak. At Frosty Peak in the Russell Creek valley, a paleosol overlain by till yielded a radiocarbon age of 1,060 yr B.P. (calibrated age, sample TDS-96-09A, Wilson and others, 1997), indicating a Neoglacial glacier had extended as much as $5 \mathrm{~km}$ down-valley from the cirque head. We cannot explain the unusually great distance that this particular Neoglacial glacier extended. However, we presume that it must bear some relation to the newly recognized history of multiple Holocene eruptive events at Frosty Peak Volcano.

\section{Conclusions}

The glacial and volcanic record of the map area provides evidence strongly suggestive of a region dominated by continental shelf glaciations and three massive volcanic centers during Pleistocene time. Morzhovoi and Emmons Volcanoes were major impediments to flow of shelf glaciers during much of the Pleistocene. Our model suggests that the area around Emmons Volcano may have also been an important source area for glaciers during this period. The map data further indicate that Frosty Volcano developed late in the Pleistocene and had no apparent impact on early Brooks Lake glacial advances. It did, however, serve as a source area for later glacial advances of Brooks Lake age. Early in the Brooks Lake glacial episode, glaciers derived from the continental-shelf ice sheet and from the Emmons Caldera region (fig. 8) flowed northward over the volcanic islands that would today form the core of the Alaska Peninsula. During this period, we believe Morzhovoi Volcano was already extinct, Emmons had already erupted, and the Pavlof group of volcanoes had yet to form. Mount Dutton may have existed as a volcano at this time, although we have little data to confirm this. Roundtop and Isanotski Peaks on Unimak Island probably were active, whereas the glacial record indicates that Shishaldin Volcano had not yet formed. Amak Island may not have formed by this time and is therefore not shown. During the subsequent advances of the Brooks Lake drift (fig. 9), the shelf-ice sheet is again(?) present although glaciers derived from it are less vigorous in crossing the Alaska Peninsula. Earlier in the time frame of fig. 8, alpine moraines derived from the Emmons buttress and a small alpine and shelf(?) glacier tongue passing by Mt. Dutton join in the Joshua Green Valley. Tongues from the shelf-ice sheet enter Cold Bay and partially cross through False Pass; no evidence is available to indicate whether a tongue extended into Morzhovoi Bay. However, the shelf ice must have abutted the remains of Morzhovoi Volcano as evidenced by the lakes dammed in a few of the south-facing valleys. Toward the end of the late Wisconsin, Frosty Volcano formed and became the source of alpine glaciers equivalent in age with the latest Brooks Lake advance (Iliuk). These alpine glaciers actually extended over deposits of a more extensive Brooks Lake advance (Newhalen). At some time after, or in the waning stage of the Brooks Lake drift, an ash flow was erupted from one of the northern Pavlof 


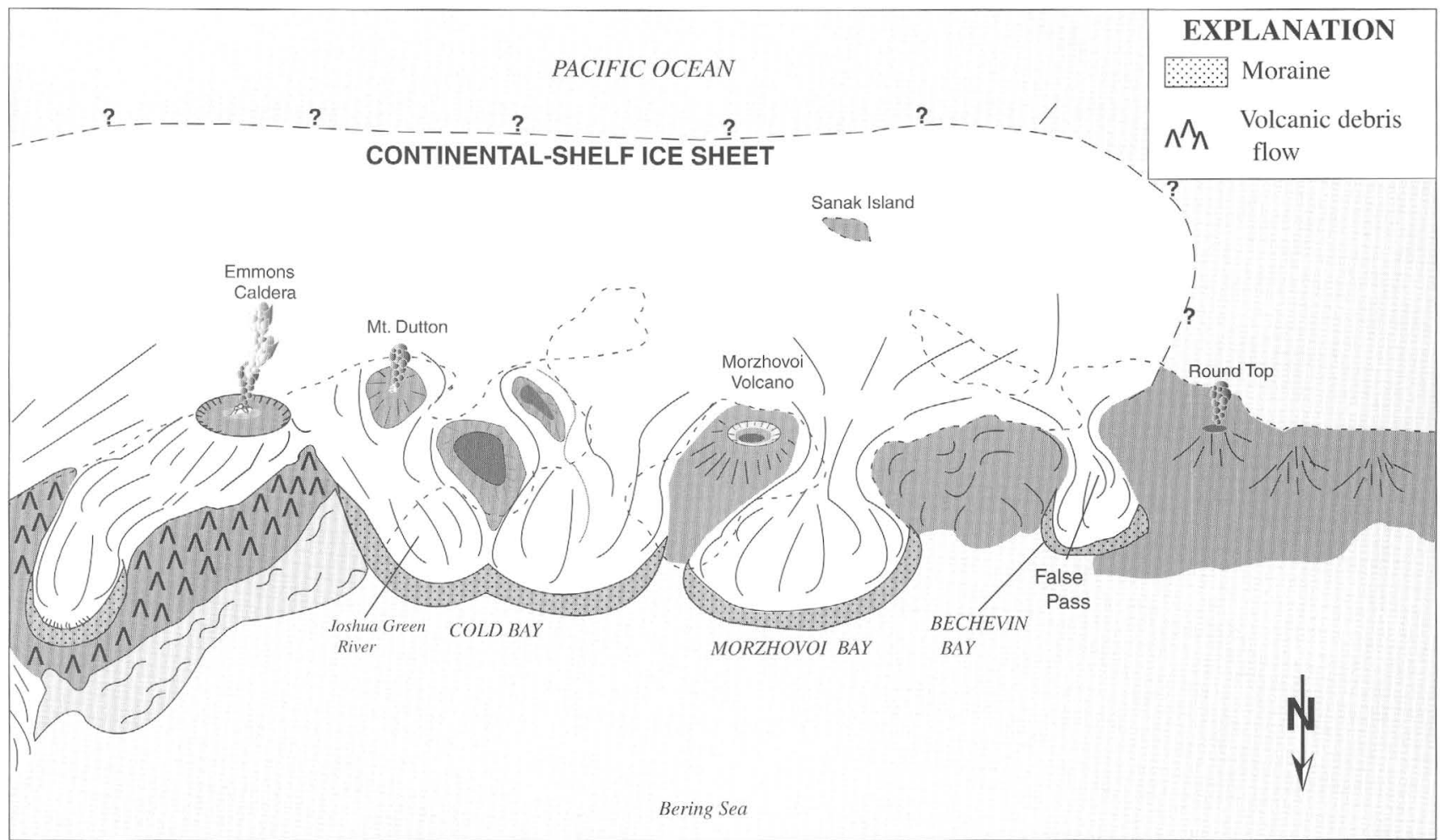

Figure 8. Sketch showing a possible scenario for the environment of the Cold Bay region during the Kvichak or lliamna advances of the Brooks Lake drift. Inverted "v" pattern indicates debris deposits derived from the eruption of Emmons Volcano; wavy lines indicate area below mapped Pleistocene shoreline. Dotted pattern indicates moraines of active or recently active glaciers.

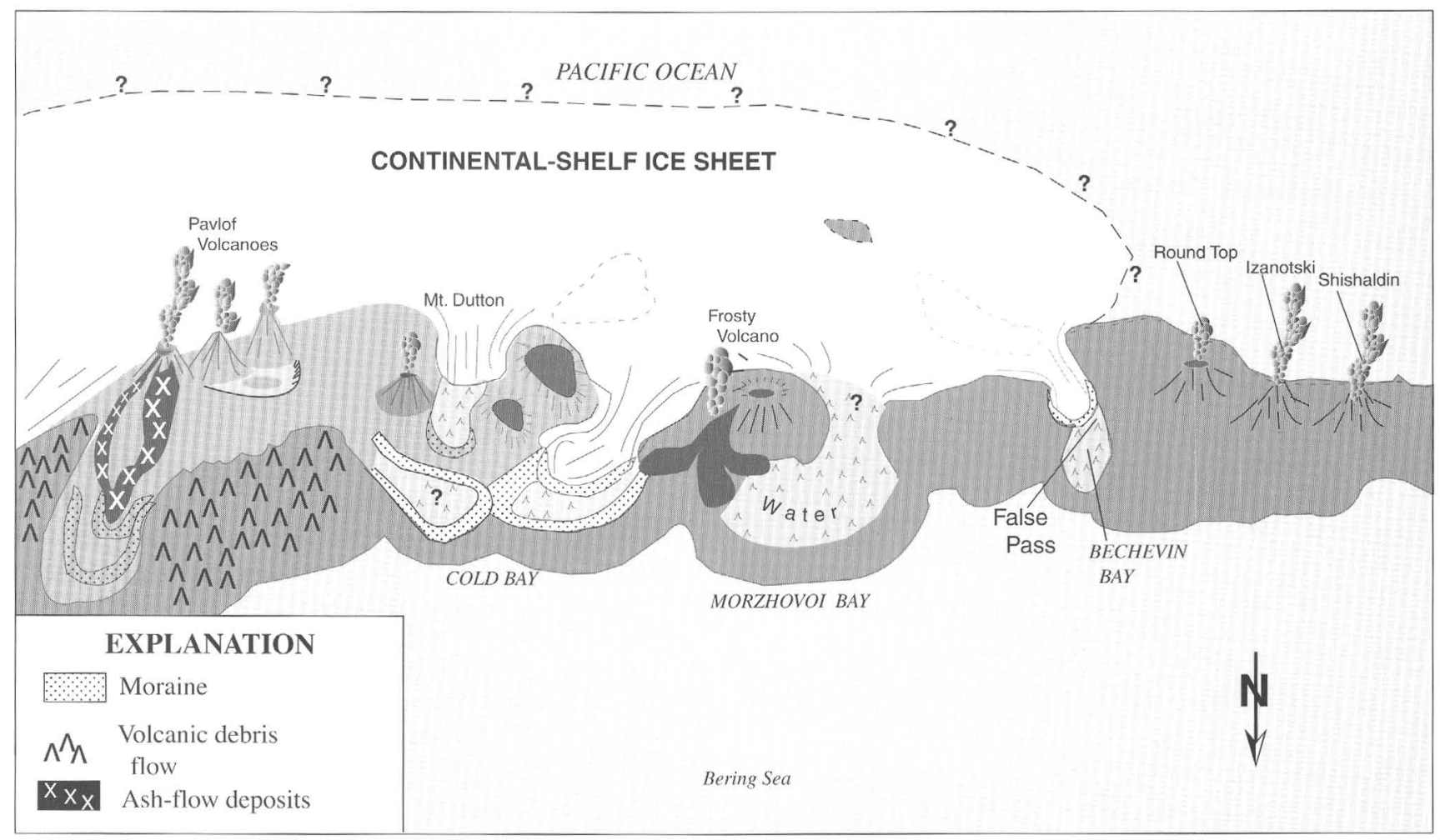

Figure 9. Sketch showing a possible scenario for the environment of the Cold Bay region during the latter advances of the Brooks Lake drift. Inverted " $v$ " pattern indicates debris deposits derived from the eruption of Emmons Volcano; " $x$ " pattern indicates late Pleistocene(?) ash-flow deposits derived from Pavlof group of volcanoes. Dotted pattern indicates moraines of active or recently active glaciers. 
group of volcanoes and was dammed behind one of the youngest Brooks Lake moraines in Cathedral Valley. Our map data also show that Frosty Volcano had a number of major Holocene eruptions, yielding multiple debris and ash flows and resulting in the construction of the south summit, filling an earlier crater. Age control on the events we describe is severely limited due to lack of appropriate material for age dates; realistically, most events are only broadly constrained in time. Nevertheless, the events we describe (table 5) fit reasonably well within the generally accepted stratigraphic succession for the Alaska Peninsula, given variations based on the local volcanic and tectonic history.

Table 5. Summary table of the Cold Bay area Quaternary events.

\begin{tabular}{|c|c|c|c|}
\hline Age & Emmons buttress & $\begin{array}{c}\text { Morzhovoi Volcano-Frosty Peak } \\
\text { buttress }\end{array}$ & Ikatan Peninsula and Unimak Island \\
\hline Holocene & $\begin{array}{l}\text { Construction of the Pavlof } \\
\text { group of volcanoes; } \\
\text { minor eruptions within } \\
\text { Emmons caldera }\end{array}$ & $\begin{array}{l}\text { Continued eruption, } \\
\text { Frosty Volcano }\end{array}$ & $\begin{array}{l}\text { Construction of Shishaldin } \\
\text { Volcano }\end{array}$ \\
\hline Holocene & & Multiple Neoglacial advances & $\begin{array}{l}\text { Minor evidence for } \\
\text { Neoglacial advances }\end{array}$ \\
\hline late Wisconsin & & $\begin{array}{l}\text { Iliuk advance } \\
\text { Newhalen advance }\end{array}$ & $\begin{array}{l}\text { Iliuk advance } \\
\text { Newhalen advance }\end{array}$ \\
\hline early Wisconsin & $\begin{array}{l}\text { Iliamna advance } \\
\text { Kvichak advance }\end{array}$ & $\begin{array}{l}\text { Iliamna advance } \\
\text { Kvichak advance }\end{array}$ & $\begin{array}{l}\text { Iliamna advance? } \\
\text { Kvichak advance? }\end{array}$ \\
\hline pre-Wisconsin & Mak Hill drift sheet & & Mak Hill drift sheet \\
\hline pre-Wisconsin & Johnston Hill drift sheet & & \\
\hline pre-Wisconsin & oldest drift & & \\
\hline
\end{tabular}

\section{Acknowledgments}

Robert L. (Buck) Detterman's death as the 1992 version of the Cold Bay and False Pass quadrangle geologic map was being compiled left a profound void. His knowledge of and insight into Alaska Peninsula geology was of tremendous value. His friendship, guidance, and contributions to Alaska Peninsula geology will be long remembered.

Field studies by the following geologists are gratefully acknowledged for their contributions to the mapping and compilation: S.W. Bie, 1991; R.L. Detterman, 1984, 1988; T.M. Dochat, 1995-1996; G.D. DuBois, 1988, 1990; T.P. Miller, 1973-75, 1977-79, 1981-82, 1986-89, 1995-1996; D.H. Richter, 1986; T.L. Vallier, 1991; W.H. White, 1988, 1990-91; M.E. Yount 1983, 1986-88.

The staff of the U.S. Fish and Wildlife Service office at Cold Bay was extremely helpful in providing logistical support and in granting Special Use Permits for access to lands of the Wildlife Refuge. Peter Pan Seafoods in False Pass and Buck and Shelly Laukitis at Stonewall Place both went out of their way to provide comfortable lodging and enjoyable meals that helped make our work go much easier during our stays with them.

\section{References Cited}

Björnsson, Helgi, 1975, Subglacial water reservoirs, jökulhlaups and volcanic eruptions: Jökull, v. 25, p. 1-14.

Brophy, J.G., 1984, The chemistry and physics of Aleutian Arc volcanism: The Cold Bay Volcanic Center, southwestern Alaska: Baltimore, Maryland, Johns Hopkins University Ph.D. dissertation, $422 p$.

Burk, C.A., 1965, Geology of the Alaska Peninsula-Island arc and continental margin: Geological Society of America Memoir 99, 250 p., scales 1:250,000 and 1:500,000, 3 sheets.

Detterman, R.L., 1986, Glaciation of the Alaska Peninsula, in Hamilton, T.D., Reed, K.M., and Thorson, R.M., Glaciation in Alaska, the Geologic Record: Anchorage, Alaska, The Alaska Geological Society, p. 151-170.

Detterman, R.L., 1990, Stratigraphic correlation and interpretation of exploratory wells, Alaska Peninsula: U.S. Geological Survey OpenFile Report 90-279, 51 p., 2 sheets.

Detterman, R.L., Miller, T.P., Yount, M.E., and Wilson, F.H., 1981, Quaternary geologic map of the Chignik and Sutwik Island quadrangles, Alaska: U.S. Geological Survey Miscellaneous Investigations Series Map 1-1292, scale 1:250,000. 
Detterman, R.L., Case, J.E., Miller, J.W., Wilson, F.H., and Yount, M.E., 1996, Stratigraphic framework of the Alaska Peninsula: U.S. Geological Survey Bulletin 1969-A, 74 p.

Dochat, T.M., 1997, Quaternary stratigraphy and geomorphology of the Cold Bay region of the Alaska Peninsula: A basis for paleoenvironmental reconstruction: Madison, Department of Geology and Geophysics, University of Wisconsin Ph.D. dissertation, $279 \mathrm{p}$.

DuBois, G.D., Wilson, F.H., Detterman, R.L., and Hopkins, R.T., Jr., 1989, Reconnaissance geology and exploration geochemistry of King Cove, Alaska Peninsula: U.S. Geological Survey Open-File Report $89-350,23 \mathrm{p}$.

Finch, R.H., 1934, Shishaldin Volcano: Proceedings of the Fifth Pacific Science Conference, Canada, v. 3, p. 2369-2376 [cited in Fournelle, 1988].

Fournelle, J.H., 1988, The geology and petrology of Shishaldin Volcano, Unimak Island, Aleutian Arc, Alaska: Baltimore, Department of Earth and Planetary Sciences, Johns Hopkins University Ph.D. dissertation, 507 p., 2 plates, scale 1:25,000.

Fournelle, J.H., 1990, Shishaldin, eastern Aleutian Islands, in Wood, C.A., and Kienle, Jurgen, eds., 1990, Volcanoes of North America, United States and Canada: New York, Cambridge University Press, p. 48-49.

Funk, J.M., 1973, Late Quaternary geology of Cold Bay, Alaska, and vicinity: Storrs, Department of Geology and Geophysics, University of Connecticut M.S. thesis, $45 \mathrm{p}$.

Funk, J.M., 1976, Late Quaternary history of the western Alaska Peninsula and possible effects on the ancestral Aleuts: manuscript for the Alaska Anthropology Association Meeting, March, 1976, 21 p.

Hamilton, T.D., and Brigham-Grette, Julie, 1992, The last interglaciation in Alaska-Stratigraphy and paleoecology of potential sites: Quaternary International, v. 10-12, p. 49-71.

Jònsson, Jòn, 1982, Notes on the Katla volcanoglacial debris flows: Jökull, v. 32, p. 61-68.

Jordan, James, 1997, Report of research activities during 1995-96, Lower Alaska Peninsula Project: Madison, Department of Geography, University of Wisconsin-Madison, written commun., $5 \mathrm{p}$.

Kaufman, D.S., Thompson, C.H., and Lea, P.D., 1995, Re-evaluation of pre-late-Wisconsin glacial deposits, Naknek River area, SW Alaska [abs.]: Geological Society of America Abstracts with Programs, v. 27, no. 5 , p. 57.

Kennedy, G.C., and Waldron, H.H., 1955, Geology of Pavlof Volcano and vicinity, Alaska: U.S. Geological Survey Bulletin 1028-A, 19 p., scale 1:100,000.

Mann, D.H., and Peteet, D.M., 1994, Extent and timing of the last glacial maximum in southwestern Alaska: Quaternary Research, v. 42, p. $136-148$.

McLean, Hugh, Englehardt, C.L., and Howell, D.G., 1978, Reconnaissance geologic map of the Cold Bay and False Pass quadrangles, Alaska: U.S. Geological Survey Open-File Report 78-323, scale $1: 250,000$.

Miller, T.P., 1990, Fisher, eastern Aleutian Islands, in Wood, C.A., and Kienle, Jurgen, eds., 1990, Volcanoes of North America,
United States and Canada: New York, Cambridge University Press, p. 46-48.

Miller, T.P., and Smith, R.L., 1987, Late Quaternary caldera-forming eruptions in the eastern Aleutian arc, Alaska: Geology, v. 15, p. 434-438.

Muller, E.H., 1953, Northern Alaska Peninsula and eastern Kilbuck Mountains, in Péwé, T.L., and others, Multiple Glaciation in Alaska-A Progress Report: U.S. Geological Survey Circular 289, p. 2-3.

Pinney, D.S., 1993, Late Quaternary glacial and volcanic stratigraphy near Windy Creek, Katmai National Park, Alaska: Fairbanks, University of Alaska, Fairbanks, M.S. thesis, $131 \mathrm{p}$.

Pinney, D.S., and Beget, J.E., 1991, Deglaciation and latest Pleistocene and early Holocene glacier readvances on the Alaska Peninsula-Records of rapid climate change due to transient changes in solar intensity and atmospheric $\mathrm{CO}_{2}$ content?, in Weller, $\mathrm{G}$., Wilson, C.L., and Severing, B.A.B., eds., International Conference on the Role of Polar Region in Global Change: Fairbanks, University of Alaska Fairbanks, p. 634-640.

Riehle, J.R., and Detterman, R.L., 1993, Quaternary geologic map of the Mount Katmai quadrangle and adjacent parts of the Naknek and Afognak quadrangles, Alaska: U.S. Geological Survey Miscellaneous Investigations Series Map I-2032, scale 1:250,000.

Stilwell, K.B., and Kaufman, D.S., 1996, Late Wisconsin glacial history of the northern Alaska Peninsula, southwestern Alaska, U.S.A: Arctic and Alpine Research, v. 28, no. 4, p. 475-487.

Tòmasson, Haukur, 1996, The jökulhlaup from Katla in 1918: Annals of Glaciology, v. 22, p. 249-254.

Veniaminov, Ivan, 1840, Notes on the islands of the Unalaska district, translated by Black, L.T., and Geoghegan, R.H., edited with introduction by Pierce, R.A., [1984]: Alaska History No. 27, The Elmer E. Rasmusson Library Translation Program, Univ. of Alaska, Fairbanks, and The Limestone Press, Kingston, Ontario, Canada, 511 p.

Wadge, G., Francis, P.W., and Ramirez, C.F., 1995, The Socompa collapse and avalanche event: Journal of Volcanology and Geothermal Research, v. 66, p. 309-336.

Waldron, H.H., 1961, Geologic reconnaissance of Frosty Peak volcano and vicinity, Alaska: U.S. Geological Survey Bulletin 1028-T, p. 677-708.

Wilson, F.H., Weber, F.R, Dochat, T.M., Miller, T.P., and Detterman, R.L, 1997, Revised geologic map of the Cold Bay and False Pass quadrangles, Alaska Peninsula: U.S. Geological Survey Open-File Report 97-866, scale 1:250,000,34 p. pamphlet.

Winslow, M.A., and Johnson, L.L., 1988, Paleoseismic and Aleut migration patterns in a tectonically unstable environment: Shumagin Islands, Alaska: Geological Society of America, Abstracts with Programs, v. 20, no. 7, p. 168.

Winslow, M.A., and Johnson, L.L., 1989a, Prehistoric human settlement patterns in a tectonically unstable environment: Outer Shumagin Islands, southwestern Alaska: Geoarchaeology: An International Journal, v. 4, no. 4, p. 297-318.

Winslow, M.A., and Johnson, L.L., 1989b, Tectonic, eustatic, and isostatic controls on prehistoric coastal settlements in the Shumagin 
Islands, southwest Alaska [abs.]: Geological Society of America, Abstracts with Programs, v. 21, no. 6, p. A213.

Yount, M.E., Miller, T.P., Emanuel, R.P., and Wilson, F.H., 1985, Eruption in the ice-filled caldera of Mount Veniaminof, in Bartsch-Winkler, Susan, and Reed, K.M., eds., The United States Geological Survey in Alaska, Accomplishments During 1983: U.S. Geological Survey Circular 945, p. 59-60. [The front and back covers of the Circular show many photographs of the eruption.]
Reviewers: W. Hildreth, J.P. Galloway 



\title{
Reconnaissance Geology North of the Hoholitna River, Taylor Mountains D-1 1:63,360-Scale Quadrangle, Southwestern Alaska
}

\author{
By Robert B. Blodgett and Frederic H. Wilson
}

\begin{abstract}
The lower Paleozoic (Silurian and Ordovician) carbonate stratal succession is divided into six unnamed stratigraphic units in the northern part of the Taylor Mountains D-1 1:63,360-scale quadrangle of southwestern Alaska. Several of these units have previously been recognized in the McGrath and Medfra quadrangles to the northeast in strata of the Nixon Fork subterrane of the Farewell terrane (Decker and others, 1994). These rocks occur along the south side of a prominent east-west-trending anticlinorial axis exposed slightly to the north in the Sleetmute A-2 1:63,360-scale quadrangle. Rocks of the Nixon Fork subterrane are now thought to represent a continental margin sequence rifted from Siberia. The low thermal alteration indices exhibited by the rocks of this area have elicited interest for petroleum exploration. However, low total organic carbon (TOC) values from potential source rocks within this lower Paleozoic succession indicate low petroleum potential.
\end{abstract}

\section{Introduction}

Paleozoic rocks comprise nearly the entire exposed bedrock in the northern part (north of the Hoholitna River) of the Taylor Mountains D-1 quadrangle, southwestern Alaska (fig. 1). Bedrock exposures south of the Hoholitna River largely consist of Upper Cretaceous sedimentary strata of the Kuskokwim Group and possible Mesozoic rocks of the Mesozoic and Paleozoic Gemuk Group of Platt (1957?); no Paleozoic rocks are known. No direct contact between the Kuskokwim Group and Paleozoic rocks has been observed in the Taylor Mountains D-1 quadrangle. The study area (fig. 2) is in the south-central portion of the Holitna Lowland physiographic division of Wahrhaftig (1965), an area covered predominantly by marshy tundra. Sporadic outcroppings of Paleozoic-age rocks (mainly carbonates) form prominent ridges that rise above the lowlands. The oldest rocks in the region are carbonates and siliciclastics of probable Late Proterozoic age. These rocks crop out to the northwest of the study area in a broadly crescent-shaped east-west-trending outcrop belt occupying the axis of a large anticlinorium in the Sleetmute A-2 quadrangles (Babcock and others, 1994; Jacobson and others, 1996).

The preliminary geologic data for the Taylor Mountains D-1 quadrangle north of the Hoholitna River are based on field studies conducted in the mid-1980's by the petroleum industry and the Alaska Division of Geological \& Geophysical Surveys (ADGGS), in 1998 by ADGGS, and in 1999 by the U.S. Geological Survey. Exposed sedimentary bedrock is of early and middle Paleozoic (Silurian and Ordovician) age and primarily consists of carbonate (limestone and dolostone) lithology; one minor siliciclastic unit is recognized. These rocks were previously considered to belong to the now-abandoned Holitna Group of Cady and others (1955). This term was applied to all Paleozoic carbonates exposed along the middle course of the Holitna River and surrounding area; no subdivisions were designated for this group. Fossils of Silurian and Devonian age were reported by Cady and others (1955), but they inferred that Ordovician strata were perhaps also present because of their occurrence in correlative rocks in the Medfra quadrangle to the northeast, as well as the fact that the Silurian and Devonian fauna recovered were only from the upper part of the Holitna Group. They estimated the thickness of the group "to be at least 5,000 and probably closer to 10,000 feet thick" (Cady and others, 1955, p. 24). On the basis of field work conducted in the region since 1983, it is now obvious that rocks originally assigned to the Holitna Group have a much greater total thickness and include strata as old as Neoproterozoic and as young as Triassic. Adrain and others (1995, p. 724) have suggested that the term Holitna Group was too broadly defined and should be abandoned in favor of more finely divided stratigraphic units. The Paleozoic strata described here were shown as assigned to the Nixon Fork terrane of Patton (1978) by Coney and others (1980). This terrane subsequently was recognized by Decker and others (1994) to be genetically 


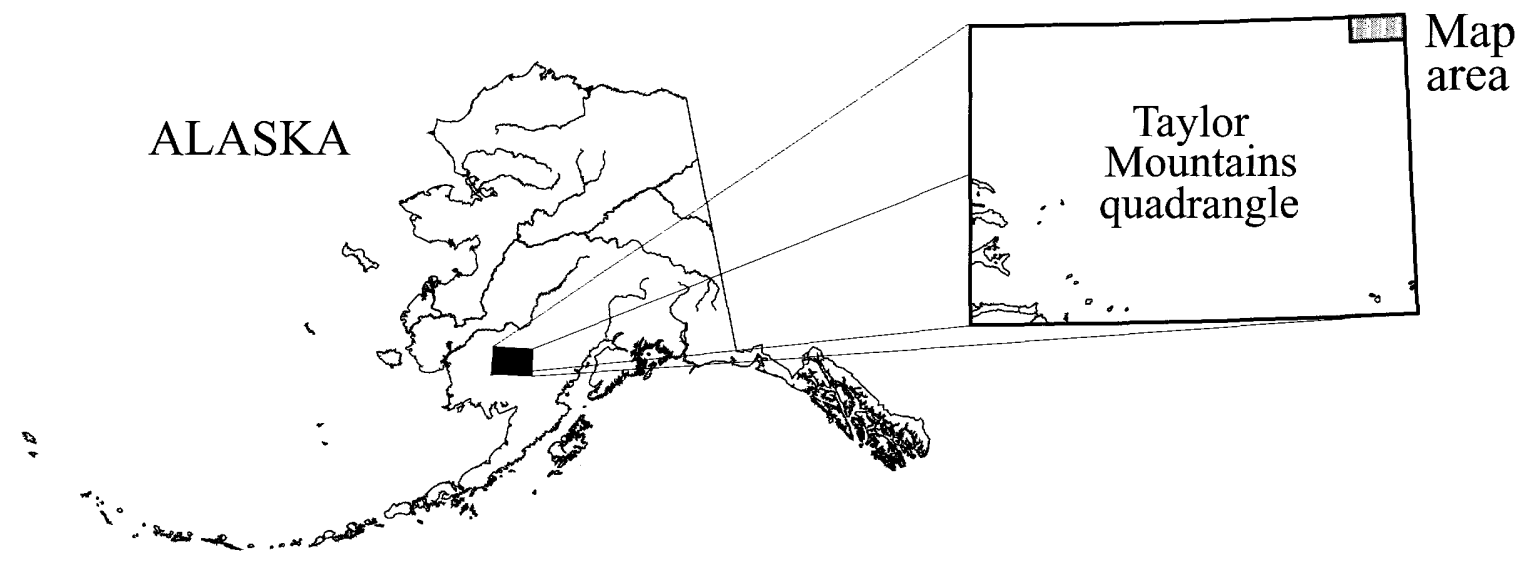

Figure 1. Index map of the region.

related to the Dillinger and Mystic terranes. Decker and others suggested designating these as "subterranes" and proposed the term Farewell terrane to unite them. Recent work on the biogeographic affinities of Farewell terrane fossil biotas indicates that it is a continental margin sequence that probably rifted from the Siberian paleo-continent, or, less likely, from the northeastern part of Baltica (Palmer and others, 1985; Blodgett, 1998; Blodgett and Boucot, 1999; Blodgett and others, 1999).

This report presents detailed geologic information for Paleozoic rocks within the Taylor Mountains D-1 quadrangle portion of the Holitna Lowland. This region, in comparison with much of Alaska, remains a true terra incognita. The lower Paleozoic strata of the map area provide a nearly complete record of Silurian and Ordovician sedimentation in southwestern Alaska. In view of their relatively low degree of thermal alteration, these rocks have been considered an attractive target for petroleum exploration. The relatively excellent state of preservation of megafossils (graptolites, brachiopods, trilobites) and carbonate rock fabrics also makes the area highly desirable for detailed stratigraphic investigations.

\section{Discussion}

The oldest stratigraphic entity recognized in the study area is a burrow-mottled limestone (Ols) unit consisting of thin- to medium-bedded, yellow-gray-weathering, dark-gray fresh, lime mudstone and lesser peloidal mudstone. The unit is exposed only in the northwestern part of the study area and is separated from the overlying algal limestone (Oab) unit by tundra cover in the eastern area of its exposure and by a vertical fault in the western part of its exposure. A relatively diverse assemblage of conodonts was identified by A.G. Harris from fossil locality 13 (table 1, fig. 2) as indicative of an early Arenigian age (Early Ordovician, low Fauna D). Harris (writ- ten commun., 1986) noted that the collection contains a form identified as Fryxellidontus? n. sp., which she found interesting because, although age equivalent rocks are widespread on the western Seward Peninsula and across the central Brooks Range, Fryxellidontus? n. sp. is found only in the western Seward Peninsula. Poorly preserved low-spired gastropods identified by D.M. Rohr and R.B. Blodgett from fossil locality 12 (table 1, fig. 2) contain forms suggestive of the genus Lecanospira, indicative of an Early Ordovician age. On the basis of lithology and faunal content, the unit records shallow-water, inner carbonate platform conditions. Unit Ols is age correlative with the Novi Mountain Formation of Dutro and Patton (1982) from the Medfra quadrangle; however, Ols appears to represent a much shallower depositional environment.

As noted above, the overlying unit (Oab), which is largely composed of dark-gray algal limestone, is separated from the underlying Ols unit by tundra cover or by a vertical fault. Unit Oab consists of medium- to thick-bedded, dark-gray to brown, algal thrombolites (boundstone) interbedded with lightgray-weathering thin- to medium-bedded lime mudstone. The boundstone is comprised of spongiostromate algal buildups that are typically darker in color, thinner bedded, and have a different suite of accessory algal and biotic components than the algal boundstone of the overlying Silurian algal boundstone (Sab) unit. Trilobites identified by J.M. Adrain from fossil localities 1 and 5 are not very diagnostic; a specimen from locality 1 , although clearly a piece of trilobite, is too poorly preserved for identification. At locality number 5 , Adrain reports the trilobite fragments collected are generally referred to as an "effaced styginid." He says that, in general, taxonomy of "bumastines," styginids, and "scutelluines" is in flux. This particular taxon has fan-shaped pygidial pleural ribbing in the smaller tail fragments and on the ventral surface of larger specimens and is likely a styginid as opposed to an illaenid. 


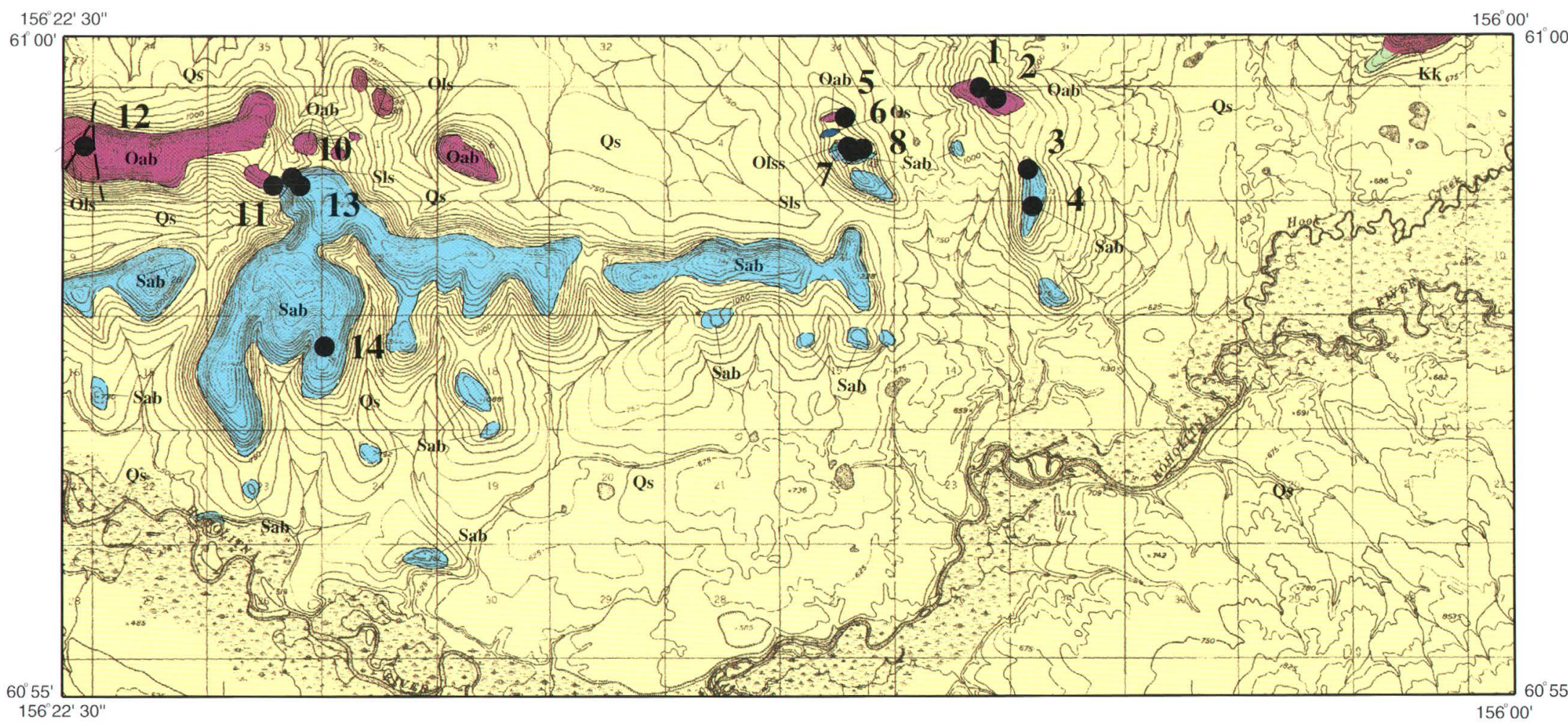

Qs Surficial deposits, undifferentiated (Quaternary)

Olss Tcherskidium-bearing limestone (Asgillian, Late Ordovician)

Kk Kuskokwim Group, undivided (Late Cretaceous and late Early

Os Shale (Ordovician, undifferentiated) Cretaceous

\section{Sab Algal boundstone (Late Silurian)}

Oab Dark-gray algal limestone (Early Ordovician)

\section{Sls Platy limestone}

\section{Ols Burrow-mottled limestone (Early Ordovician)}

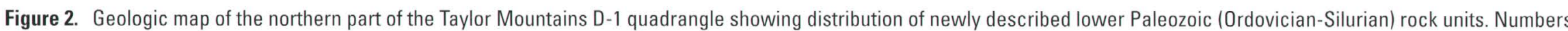
refer to fossil localities mentioned in text and correspond to "Map no." on table 1. 
Table 1. Fossil data from the northern part of the Taylor Mountain D-1 quadrangle, Alaska.

[Collector's initials from various geological investigations are: RB (Robert B. Blodgett; while consulting for ADGGS, USGS, Sohio, Union Oil Company, and ARCO), AKE (Sohio Field Party, 1984 consisting of Bob Egbert, Ray Sullivan, Jeff Knoth, Robert B. Blodgett), TNS (Thomas N. Smith, ADGGS), JC (James G. Clough, ADGGS). Abbreviations used: CAI, conodont color alteration index; indet., indeterminate. See Acknowledgements for affiliations of fossil identifiers.]

\begin{tabular}{|c|c|c|c|c|c|c|}
\hline $\begin{array}{l}\text { Map no., } \\
\text { map unit }\end{array}$ & Location & Field no. & Fossils & Fossil age & Reference & Comments \\
\hline $\begin{array}{c}1 \\
\text { Oab }\end{array}$ & $\begin{array}{l}\mathrm{NE}^{1 / 4}, \text { sec. } 2 \\
\text { T. } 10 \mathrm{~N} . \\
\text { R. } 39 \mathrm{~W} .\end{array}$ & 99RB42 & $\begin{array}{l}\text { Smooth indeterminate trilobite carapace } \\
\text { and undetermined algal remains }\end{array}$ & Probably Ordovician & $\begin{array}{l}\text { Jonathan Adrain, } \\
\text { written commun., } \\
\text { Jan. } 14,2000 \text {, for } \\
\text { trilobite; R.B. } \\
\text { Blodgett for fossil } \\
\text { algae }\end{array}$ & \\
\hline Oab & $\begin{array}{l}\text { NE } 1 / 4, \text { sec. } 2, \\
\text { T. } 10 \text { N., } \\
\text { R. } 39 \text { W. }\end{array}$ & 84AKE79 & $\begin{array}{l}\text { Conodont: } \\
1 \text { element of Semiacontiodus sp. }\end{array}$ & Early Ordovician & $\begin{array}{l}\text { N.M. Savage (written } \\
\text { commun., May 23, } \\
1985 \text { ) }\end{array}$ & $\begin{array}{l}\text { CAI: } 2.5 \text {; } \\
\text { probably same locality as } 99 \mathrm{RB} 41\end{array}$ \\
\hline Sab & $\begin{array}{l}\text { SW } 1 / 4, \text { sec. } 1 \text {, } \\
\text { T. } 10 \text { N., } \\
\text { R. } 39 \text { W. }\end{array}$ & 99RB43 & $\begin{array}{l}\text { Numerous gastropods in cross-section; } \\
\text { undetermined, medium-sized, smooth } \\
\text { brachiopod; favositid corals }\end{array}$ & Late Silurian & R.B. Blodgett & $\begin{array}{l}\text { Although gastropods could not be } \\
\text { cracked out from matrix, the } \\
\text { morphotypes present are consistent } \\
\text { with Late Silurian forms seen } \\
\text { elsewhere in the unit and its } \\
\text { equivalents }\end{array}$ \\
\hline Sab & $\begin{array}{l}\text { NW } 1 / 4, \text { sec. } 12, \\
\text { T. } 10 \text { N., } \\
\text { R. } 39 \text { W. }\end{array}$ & 84-TNS-66 & Large solitary rugose corals & Probably Silurian & A.E.H. Pedder & \\
\hline Oab & $\begin{array}{l}\text { sec. } 3 \text {, } \\
\text { T. } 10 \mathrm{~N} . \\
\text { R. } 39 \mathrm{~W}\end{array}$ & $85 \mathrm{RB} 9$ & Effaced styginid trilobites & $\begin{array}{l}\text { Ordovician (Arenig) } \\
\text {-Late Silurian }\end{array}$ & $\begin{array}{l}\text { Jonathan Adrain, } \\
\text { written commun., } \\
\text { Jan. } 14,2000\end{array}$ & \\
\hline Olss & $\begin{array}{l}\text { sec. } 3 \text {, } \\
\text { T. } 10 \mathrm{~N} . \\
\text { R. } 39 \mathrm{~W} \text {. }\end{array}$ & $84 \mathrm{RB} 134$ & $\begin{array}{l}\text { Brachiopods: } \\
\text { Numerous ventral valves of } \\
\text { Tcherskidium sp., Proconchidium (or } \\
\text { Eoconchidium) sp., and new genus of } \\
\text { smooth virgianid brachiopod aff. } \\
\text { Tcherskidium; crinoid ossicles }\end{array}$ & $\begin{array}{l}\text { Ashgillian (late Late } \\
\text { Ordovician) }\end{array}$ & R.B. Blodgett & $\begin{array}{l}\text { Occurs in coquinoid accumulation } \\
\text { (hydraulically sorted), possibly in } \\
\text { mass flow unit }\end{array}$ \\
\hline & & & Conodonts: probably Late Ordovician & & N. M. Savage & CAI:3.0 \\
\hline
\end{tabular}


Table 1. Fossil data from the northern part of the Taylor Mountain D-1 quadrangle, Alaska-Continued.

\begin{tabular}{|c|c|c|c|c|c|c|}
\hline $\begin{array}{l}\text { Map no., } \\
\text { map unit }\end{array}$ & Location & Field no. & Fossils & Fossil age & Reference & Comments \\
\hline $\begin{array}{l}7 \\
\text { Sls, in } \\
\text { transition } \\
\text { zone } \\
\text { between } \\
\text { Olss and } \\
\text { Sls }\end{array}$ & $\begin{array}{l}\text { sec. } 3 \text {, } \\
\text { T. } 10 \mathrm{~N} . \\
\text { R. } 39 \mathrm{~W} .\end{array}$ & $85 \mathrm{RB} 10$ & $\begin{array}{l}\text { Conodonts (USGS coll. 11409-SD): } \\
2 \text { Dapsilodus sp. elements, } \\
\text { Distomodus staurognathoides (Walliser) } \\
1 \mathrm{~Pa}, 1 \mathrm{~Pb}, 1 \mathrm{~m}, 1 \mathrm{Sa} \text {, and } 1 \mathrm{Sb} \\
\text { elements, } \\
\text { Ozarkodina cf. gulletensis (Aldridge) } 1 \\
\text { Pa element, } \\
\text { Panderodus } \text { sp., } 6 \text { elements, } \\
\text { Pterospathodus pennatus procerus } \\
\text { (Walliser) } 7 \mathrm{~Pa} \text { and } 2 \text { Pb elements, } \\
1 \mathrm{~Pb}, 1 \mathrm{M}, 4 \mathrm{Sb} \text { ( } 3 \text { morphotypes) and } 5 \\
\mathrm{Sc} \text { (4 morphotypes) elements, } 12 \\
\text { indet. bar and blade fragments }\end{array}$ & $\begin{array}{l}\text { Early Silurian; late } \\
\quad \text { Llandoverian } \\
\text { (=lower half of the } \\
\text { Amorphognath- } \\
\text { oides Zone) }\end{array}$ & $\begin{array}{l}\text { Anita G. Harris, written } \\
\text { commun., July } 15, \\
1986\end{array}$ & CAI: $3.5-4.0$ \\
\hline $\begin{array}{c}8 \\
\text { Sls }\end{array}$ & $\begin{array}{l}\text { sec. } 3 \text {, } \\
\text { T. } 10 \mathrm{~N} . \\
\text { R. } 39 \mathrm{~W} .\end{array}$ & 84RB37 & $\begin{array}{l}\text { Conodonts (USGS colln. 11411-SD): } \\
\text { Kockelella? sp. indet. } 1 \mathrm{~Pa} \text { (fragment) } \\
\text { and } 1 \mathrm{Sb} \text { elements; } \\
\text { Ozarkodina sp. indet., } 1 \mathrm{P} \text { and } 1 \mathrm{Sc} \\
\quad \text { element fragment } \\
\text { Panderodus sp. } 13 \text { elements, } \\
\text { Pseudooneotodus sp. } 1 \text { element, } \\
24 \text { indet. bar, blade, platform and simple } \\
\text { cone fragments }\end{array}$ & $\begin{array}{l}\text { Late Llandoverian- } \\
\text { Ludlovian (late } \\
\text { Early Silurian- } \\
\text { middle Late } \\
\text { Silurian) }\end{array}$ & $\begin{array}{l}\text { Anita G. Harris, written } \\
\text { commun., July 15, } \\
1986\end{array}$ & CAI: $2.5-3.0$ \\
\hline & & 84-TNS-1F & $\begin{array}{l}\text { Conodonts: } 1 \text { indeterminate conodont } \\
\text { element } \\
\text { Monograptid graptolites of Wenlockian } \\
\text { age }\end{array}$ & $\begin{array}{l}\text { None } \\
\\
\text { Wenlockian (early } \\
\text { Late Silurian) }\end{array}$ & $\begin{array}{l}\text { Norman M. Savage, } \\
\text { written commun., } \\
\text { May 23, } 1985 \\
\text { Hermann Jaeger, } \\
\text { written commun., } \\
1985\end{array}$ & $\begin{array}{l}\text { CAI: } 3.0 \\
\text { All three collections listed here are from } \\
\text { sites close to one another in a } \\
\text { sequence of rubbly weathering, thin, } \\
\text { platy Silurian limestone equivalent } \\
\text { to the Paradise Fork Formation of } \\
\text { Dutro and Patton, (1982) in the } \\
\text { Medfra quadrangle, and the uOll } \\
\text { unit of Gilbert (1981) in the } \\
\text { McGrath quadrangle }\end{array}$ \\
\hline
\end{tabular}


Table 1. Fossil data from the northern part of the Taylor Mountain D-1 quadrangle, Alaska-Continued.

\begin{tabular}{|c|c|c|c|c|c|c|}
\hline $\begin{array}{l}\text { Map no., } \\
\text { map unit }\end{array}$ & Location & Field no. & Fossils & Fossil age & Reference & Comments \\
\hline $\mathrm{Sab}$ & $\begin{array}{l}\text { sec. } 3 \\
\text { T. } 10 \mathrm{~N} . \\
\text { R. } 39 \mathrm{~W} .\end{array}$ & $85 \mathrm{RB} 5$ & $\begin{array}{l}\text { Sphinctozoan sponge: } \\
\text { Aphrosalpinx textilis Miagkova, } 1955\end{array}$ & $\begin{array}{l}\text { Late Silurian } \\
\text { (Ludlovian- } \\
\text { Pridolian) }\end{array}$ & $\begin{array}{l}\text { R.B. Blodgett } \\
\text { See Rigby and others } \\
\text { (1994) for } \\
\text { additional } \\
\text { information on this } \\
\text { distinctive index } \\
\text { fossil typical of Late } \\
\text { Silurian algal reef } \\
\text { buildups in the } \\
\text { Farewell terrane of } \\
\text { southwest and west- } \\
\text { central Alaska }\end{array}$ & $\begin{array}{l}\text { Only one partial fragment collected by } \\
\text { Alex Sisson of Union Oil Company, } \\
1985 \text {; this distinctive calcareous } \\
\text { sponge is commonly associated with } \\
\text { algal reef buildups and is known in } \\
\text { the Farewell and Alexander terranes } \\
\text { of Alaska, as well as along the } \\
\text { length of Ural Mountains, in Novaya } \\
\text { Zemlya, and in the Kuznetsk Basin } \\
\text { of Russia }\end{array}$ \\
\hline Sls & $\begin{array}{l}\text { SE } 1 / 4, \text { sec. } 2 \\
\text { T. } 10 \text { N., } \\
\text { R. } 40 \mathrm{~W} .\end{array}$ & 83 RB74 & $\begin{array}{l}\text { Conodonts (USGS colln. } 11405-\mathrm{SD}) \text { : } \\
2 \text { Sb elements of Ozarkodina excavata } \\
\text { (Branson and Mehl), } \\
4 \text { Sc elements of } 3 \text { morphotypes, } \\
6 \text { indet. bar and blade fragments }\end{array}$ & $\begin{array}{l}\text { Wenlockian (early } \\
\text { Late Silurian) - } \\
\text { early Emsian (late } \\
\text { Early Devonian) }\end{array}$ & $\begin{array}{l}\text { Anita G. Harris, written } \\
\text { commun., July } 15 \text {, } \\
1986\end{array}$ & CAI: $3.5-4.0$ \\
\hline Oab & $\begin{array}{l}\text { SEl/4, sec. } 2 \\
\text { T. } 10 \text { N., } \\
\text { R. } 40 \mathrm{~W} .\end{array}$ & $83 R B 75$ & $\begin{array}{l}\text { Trilobites: } 3 \text { trilobite species, including } \\
\text { Hystricurus }\end{array}$ & Early Ordovician & $\begin{array}{l}\text { Allen R. Ormiston, oral } \\
\text { commun., Jan. 26, } \\
1984\end{array}$ & $\begin{array}{l}\text { Hystricurus is similar to a species } \\
\text { described by R.J. Ross, Jr. from } \\
\text { Nevada }\end{array}$ \\
\hline 12 & $\begin{array}{l}\text { NE } 1 / 4, \text { sec. } 4, \\
\text { T. } 10 \mathrm{~N} . \\
\text { R. } 40 \mathrm{~W}\end{array}$ & $83 R B 45$ & $\begin{array}{l}\text { Poorly preserved, low-spired gastropods } \\
\text { of Ordovian aspect (suggestive of } \\
\text { Lecanospira) }\end{array}$ & Early Ordovician & $\begin{array}{l}\text { D.M. Rohr and } \\
\text { R.B. Blodgett }\end{array}$ & occurs upsection from $83 \mathrm{RB} 44$ \\
\hline 13 & $\begin{array}{l}\mathrm{NE} 1 / 4, \mathrm{sec} .4 \\
\text { T. } 10 \mathrm{~N} .\end{array}$ & $83 \mathrm{RB} 44$ & Conodonts (USGS colln. 10389-CO): & $\begin{array}{l}\text { Early Arenigian } \\
\text { (Early Ordovician; }\end{array}$ & $\begin{array}{l}\text { Anita G. Harris, written } \\
\text { commun., July } 15 \text {, }\end{array}$ & CAI: $4.0-4.5$ \\
\hline Ols & R. $40 \mathrm{~W}$. & & $\begin{array}{l}2 \text { Drepanoistodus? sp. } \\
\text { elements, } \\
5 \text { Fryxellodontus? n. sp. elements } \\
1 \text { geniculate element of Paroistoidus } \\
\text { proteus (Lindstrom), } \\
1 \text { Scolopodus floweri Repetski element, } \\
1 \text { Scolopus gracilis Ethington \& Clark } \\
\text { element, } \\
1 \text { Scolopus rex Lindstrom element, } \\
4 \text { indet. coniform fragments }\end{array}$ & low Fauna D) & 1986 & $\begin{array}{l}\text { "This is a very interesting collection, } \\
\text { chiefly because of the presence of } \\
\text { Fryxellidontus? n. sp. Rocks of low } \\
\text { Fauna D age are widespread and } \\
\text { relatively thick in the western } \\
\text { Seward Peninsula and across the } \\
\text { central Brooks Range. However, I } \\
\text { have found the Fryxellidontus?- } \\
\text { bearing beds only in the western } \\
\text { Seward Peninsula ...." }\end{array}$ \\
\hline
\end{tabular}


However, the composition and monophyly of both the styginid and illaenid groups is a matter of current debate in the literature. Unfortunately, effaced styginids range from Arenig to Upper Silurian, with little basic change in their morphology, and the available material is too sparse and fragmentary for confident generic assignment. A.R. Ormiston (oral commun., 1984) reported that a trilobite collection from fossil locality 11 contains three species, including the genus Hystricurus, indicative of an Early Ordovician age. According to Ormiston, the Hystricurus is represented by a species similar to a species described from Nevada. A single conodont element was recovered from fossil locality 2 and identified by N.M. Savage as Semiacontiodus sp., indicative of an Early Ordovician age. The abundance of algal thrombolite mound buildups and the presence of open-marine trilobite fauna suggest an outer-platform-margin depositional environment for this unit.

Overlying the Ordovician algal boundstone is a very poorly exposed Ordovician shale (unit Os). No contacts have been observed and this unit is recognized in only one area (sec. 3, T. 10 N.. R. 39 W.), where it occurs as fine rubble exposed in frost boils. The unit is composed of brown and gray "chippy" shale, silty shale, and minor silicified limestone. No age-definitive fossils are known from this unit and therefore its age is only constrained by its stratigraphic position. A poorly preserved, indeterminate brachiopod was recognized in one small sample of silicified limestone. The fine-grained, siliciclastic character of this unit suggests that it probably represents an incursion of deep-water conditions subsequent to the deposition of two previously described Lower Ordovician units. It seems plausible that the silicified limestone pebbles exposed in the frost boils may represent limestone debris flows within a basinal environment.

The next succeeding unit, a Tcherskidiumbearing limestone (Olss) unit of Ashgillian (Late Ordovician) age, is also recognized in only one part of the map area (sec. 3, T. 10 N., R. 39 W.). This unit consists of brown, medium- to thickbedded skeletal lime packstone to wackestone. Abundant pentameroid brachiopods were found at fossil locality 6 . These included three pentameroid genera: Tcherskidium n. sp.; smooth new genus aff. Tcherskidium; and either Proconchidium or Eoconchidium sp. Many of these same pentameroid species are recognized in unnamed Ashgillian carbonate strata of the McGrath C-4 1:63,360-scale quadrangle of west-central Alaska (Rohr and Blodgett, 1985). In addition, they are also found in the uppermost part of unit 8 of the Nanook Limestone (Blodgett and others, 1988) in the Shublik Mountains of the Mt. Michelson C-3 1:63,360-scale quadrangle of northeastern Alaska. The latter occurrence in the northeastern Brooks Range is from rocks considered to be of Siberian origin (Blodgett and Boucot, 1999). Sedimentologic and paleontologic evidence suggest a shallow-water, carbonate platform environment for the Tcherskidium-bearing limestone, although limited field observations also suggest the possibility of locally developed mass-flow deposits. Unit Olss is correlative with the uppermost part of the Telsitna Formation of Dutro and Patton (1982) in the Medfra quadrangle and the $\mathrm{uOl}$ unit of Gilbert (1981) in the McGrath quadrangle.

A platy limestone (Sls) unit overlies the Olss unit, but the nature of the contact remains uncertain due to tundra cover. The unit consists of thin- to medium-bedded, laminated, dark-gray to dark-brown, platy lime mudstone having a strong petroliferous odor. The lowermost beds of the unit appear lithologically transitional from the underlying Olss unit. Three-dimensional monograptid graptolites are moderately common in the middle portion of this unit. Coarse-grained limestone debris flows containing clasts of algal boundstone reef material are common in the uppermost part of the unit and increase in abundance upsection toward the overlying Silurian algal boundstone unit ( $\mathrm{Sab}$ ). The Sls unit is interpreted to have been deposited in an upper slope environment situated basinward of a prograding algal boundstone reef complex. The lowermost transitional beds of the platy limestone unit yielded conodonts at fossil locality 7 . These conodonts have been identified by A.G. Harris (written commun., 1986) as indicative of an Early Silurian age (late Llandoverian, equivalent to the lower half of the Amorphognathoides Zone). Fossil locality 8 in the middle portion of this unit yielded monograptid graptolites identified by Hermann Jaeger (written commun., 1985) as indicative of a Wenlockian (early Late Silurian) age. Conodonts from the same general locality were identified by A.G. Harris (written commun., 1986) to indicate a late LlandoverianLudlovian (late Early Silurian-middle Late Silurian) age. These fossil data allow us to assign an Early Silurian to middle Late Silurian age to the unit. The unit is both age and lithologically equivalent to the uOll unit of Gilbert (1981) in the McGrath quadrangle and the Paradise Fork Formation of Dutro and Patton (1982) in the Medfra quadrangle. 
The highest stratigraphic unit recognized in the study area is a Silurian algal boundstone (Sab) unit, which gradationally overlies the platy limestone (Sls) unit. The Sab unit consists of thick- to massive-bedded, light-gray algal boundstone, which is locally dolomitized. This unit is by far the thickest (probably at least $500 \mathrm{~m}$ thick) and most widely distributed Paleozoic unit in the study area. The boundstone is composed primarily of spongiostromate algal heads, including abundant oncoid forms. Aphrosalpingid sponges, notably Aphrosalpinx textilis Miagkova, are locally common. This distinctive calcareous sponge and its related taxa are typically associated with Late Silurian algal reef buildups known to occur along the entire length of the Ural Mountains, in Novaya Zemlya, in the Kuznetsk Basin of Siberia, as well as in the Alexander terrane and elsewhere in the Farewell terrane of Alaska (Rigby and others, 1994). Sponges (at fossil locality 9) and uncommon brachiopods (at fossil locality 14) indicate a Late Silurian (Ludlovian-Pridolian) age for the unit in the study area. The Silurian algal boundstone unit is lithologically and age equivalent to the Sl unit of Gilbert (1981) in the McGrath A-4 and A-5 quadrangles. The unit is also correlative in part with the DSwc unit of Wilson and others (1998). This unit is time transgressive elsewhere within the Holitna Lowland and the Nixon Fork subterrane and includes rocks as young as early Early Devonian (Lochkovian) age in the Lime Hills area to the northeast (Clough and Blodgett, 1985, 1988, and 1992; Blodgett and Gilbert, 1992).

\section{Petroleum Potential}

The six unnamed stratigraphic units recognized in this report form a relatively complete succession of OrdovicianSilurian strata in the northern part of the Taylor Mountains D-1 quadrangle. These rocks are situated on the southeastern flank of a prominent east-trending anticlinorial structure and have previously been assigned to the Nixon Fork subterrane of the Farewell terrane (Decker and others, 1994). Conodont color alteration index (CAI) values for rocks of the study area are quite variable, ranging in value from 2.5 to 4.5 . The general range of CAI values associated with Paleozoic strata of the Holitna Lowland are much lower than equivalent-age rocks throughout Interior Alaska, making them a potentially attractive target for petroleum explorationists. However, low TOC values from fine-grained shelf and basinal strata in the lower Paleozoic section of the southern Holitna Lowland are not indicative of significant petroleum potential (LePain and others, 2000).

\section{Acknowledgments}

Blodgett wishes to thank the following organizations for providing logistical field support into the study area in the years shown: Alaska Division of Geological \& Geophysical Surveys (1983-1984, 1998); Arco Alaska, Inc. (1983); Sohio Petroleum Company (1984); Union Oil Company (1985); and the U.S. Geological Survey (1999). We also wish to acknowledge the expertise of the following paleontologists for their identifications of various elements of the fauna: conodonts, Anita G. Harris (retired), U.S. Geological Survey, Reston, Virginia, and Norman M. Savage, University of Oregon, Eugene, Oregon; trilobites, Allen R. Ormiston, formerly of Amoco Production Co., Tulsa, Oklahoma, and Jonathan Adrain, University of Iowa, Iowa City, Iowa; graptolites, Hermann Jaeger (deceased), Museum für Naturkunde, Berlin, Germany; gastropods, David M. Rohr, Sul Ross State University, Alpine, Texas; and corals, Alan E.H. Pedder (retired), Geological Survey of Canada, Calgary, Alberta (now Sidney, British Columbia). We thank M.L. Miller, D.L. LePain, and A.J. Boucot for their thoughtful reviews of this paper.

\section{References Cited}

Adrain, J.M., Chatterton, B.D.E., and Blodgett, R.B., 1995, Silurian trilobites from southwestern Alaska: Journal of Paleontology, v. 69, p. 723-736.

Babcock, L.E., Blodgett, R.B., and St. John, James, 1994, New Late(?) Proterozoic-age formations in the vicinity of Lone Mountain, McGrath quadrangle, west-central Alaska, in Till, A.B., and Moore, T.E., eds., Geologic Studies in Alaska by the U.S. Geological Survey, 1993: U.S. Geological Survey Bulletin 2107, p. 143-155.

Blodgett, R.B., 1998, Emsian (late Early Devonian) fossils indicate a Siberian origin for the Farewell terrane, in Clough, J.G. and Larson, F., eds., Short Notes on Alaskan Geology 1997: Alaska Division of Geological \& Geophysical Surveys Professional Report 118, p. 53-61.

Blodgett, R.B., and Boucot, A.J., 1999, Late Early Devonian (late Emsian) eospiriferinid brachiopods from Shellabarger Pass, Talkeetna C-6 quadrangle, south-central Alaska and their biogeographic importance; further evidence for a Siberian origin of the Farewell and allied Alaskan accreted terranes: Senckenbergiana lethaea, v. 79, no. 1, p. 209-221.

Blodgett, R.B., and Gilbert, W.G., 1992, Paleogeographic relations of lower and middle Paleozoic strata of southwest and west-central Alaska [abs.]: Geological Society of America Abstracts with Programs, v. 24, no. 5, p. 8.

Blodgett, R.B., Rohr, D.M., Harris, A.G., and Rong Jia-yu, 1988, A major unconformity between Upper Ordovician and Lower Devonian strata in the Nanook Limestone, Shublik Mountains, northeastern Brooks Range, in Galloway, J.P., and Hamilton, T.D., eds., Geologic Studies in Alaska by the U.S. Geological Survey During 1987: U.S. Geological Survey Circular 1016, p. 18-23.

Blodgett, R.B., Sullivan, Ray, Clough, J.G., and LePain, D.L., 1999, Paleozoic paleontology of the Holitna Lowland, southwest Alaska [abs.]: Geological Society of America Abstracts with Programs, v. 31 , no. 6, p. A-39. 
Cady, W.M., Wallace, R.E., Hoare, J.M., and Webber, E.J., 1955, The central Kuskokwim region, Alaska: U.S. Geological Survey Professional Paper 268, $132 \mathrm{p}$.

Clough, J.G., and Blodgett, R.B., 1985, Comparative study of the sedimentollogy and paleoecology of middle Paleozoic algal and coralstromatoporoid reefs in Alaska [abs.], in Gabrie, G., and Salvat, B., eds., Proceedings of the Fifth International Coral Reef Congress, Papeete, Tahiti, 1985, v. 2, p. 78, v. 3, (text), p. 593-598.

Clough, J.G., and Blodgett, R.B., 1988, Silurian-Devonian algal reef mound complex of southwest Alaska, in Geldsetzer, H.H.J., James, N.P., and Tebbutt, G.E., eds., Reefs, Canada and adjacent areas: Canadian Society of Petroleum Geologists Memoir 13, p. 404-407.

Clough, J.G., and Blodgett, R.B., 1992, A southwest Alaska Late Silurian-Early Devonian algal reef-rimmed carbonate ramp: Depositional cycles and regional significance [abs.]: Geological Society of America Abstracts with Programs, v. 24, no.5, p. 16.

Coney, P. J., Jones, D. L., and Monger, J. W. H., 1980, Cordilleran suspect terranes: Nature, v. 288, p. 329-333.

Decker, John, Bergman, S.C., Blodgett, R.B., Box, S.E., Bundtzen, T.K., Clough, J.G., Coonrad, W.L., Gilbert, W.G., Miller, M.L., Murphy, J.M., Robinson, M. S., and Wallace, W.K., 1994, Geology of southwestern Alaska, in Plafker, George, and Berg, H.C., eds., The Geology of Alaska: Boulder, Colo., Geological Society of America, The Geology of North America, v. G-1, p. 285-310.

Dutro, J.T., Jr., and Patton, W.W., Jr., 1982, New Paleozoic formations in the northern Kuskokwim Mountains, west-central Alaska: U.S. Geological Survey Bulletin 1529-H, p. H13-H22.

Gilbert, W.G., 1981, Preliminary geologic map of the Cheeneetnuk River area, Alaska: Alaska Division of Geological \& Geophysical Surveys Alaska Open-File Report AOF-153, 10 p., 2 sheets, scale $1: 63,360$.

Jacobson, S., Blodgett, R.B., and Babcock, L.E., 1996, Organic matter and thermal maturation of lower Paleozoic rocks from the Nixon Fork subterrane, west-central and southwestern Alaska, in Moore, T.E., and Dumoulin, J.A., eds., Geologic Studies in Alaska by the U.S. Geological Survey, 1994: U.S. Geological Survey Bulletin 2152, p. 81-87.
LePain, D.L, Blodgett, R.B., Clough, J.G., and Ryherd, T., 2000, Stratigraphy and petroleum potential of the Holitna region, southwest Alaska: Alaska Division of Geological \& Geophysical Surveys Preliminary Interpretative Report 2000-1, 23 p., 1 plate, scale 1:250,000.

Palmer, A.R., Egbert, R.M., Sullivan, R., and Knoth, J.S., 1985, Cambrian trilobites with Siberian affinities, southwestern Alaska [abs.]: Ameriican Association of Petroleum Geologists Bulletin, v. 69, p. 295.

Patton, W.W., Jr., 1978, Juxtaposed continental and ocean-island arc terranes in the Medfra quadrangle, west-central Alaska, in Johnson, K.M., ed., The United States Geological Survey in Alaska: Accomplishments During 1977: U.S. Geological Survey Circular 772-B, p. B38-B39.

Platt, J.N., 1957(?), Photogeologic map of the Taylor Mountains quadrangle: U.S. Geological Survey, unpub. manuscript map.

Rigby, J.K., Nitecki, M.H., Soja, C.M., and Blodgett, R.B., 1994, Silurian aphrosalpingid sphinctozoans from Alaska and Russia: Acta Palaeontologica Polonica, v. 39, p. 341-391.

Rohr, D.M., and Blodgett, R.B., 1985, Upper Ordovician Gastropoda from west-central Alaska: Journal of Paleontology, v. 59, p. 667-673.

Wahrhaftig, Clyde, 1965, Physiographic divisions of Alaska: U.S. Geological Survey Professional Paper 482, $52 \mathrm{p}$.

Wilson, F.H., Dover, J.H., Bradley, D.C., Weber, F.R., Bundtzen, T.K., and Haeussler, P.J., 1998, Geologic map of Central (Interior) Alaska: U.S. Geological Survey Open-File Report 98-133, text 63 p., appendix A, 13 p., 3 sheets, scale 1:500,000.

Reviewers: A.J. Boucot, D.L. LePain, and M.L. Miller 


\section{Geologic Units}

A tabular list of geologic units exposed in the study area follows, proceeding from youngest to oldest. The areal distribution of these units is shown in figure 2. Table 1 gives a list of identified taxa from all known fossil localities within the study area.

Qs Surficial deposits, undifferentiated (Quaternary)Unconsolidated silt, sand, and gravel of fluvial, glacial, colluvial, and other origins

Kk Kuskokwim Group, undivided (Late Cretaceous and late Early Cretaceous) - Sandstone, siltstone, shale, and conglomerate. Includes fine- to coarsegrained, greenish-gray to gray, thinly cross bedded sandstone and quartz-chert pebble conglomerate having poorly exposed interbeds of dark shale and siltstone. Unit is widely distributed in southwestern Alaska (see Decker and others, 1994)

Sab Algal boundstone (Late Silurian) - Thick- to massive-bedded, light-gray algal boundstone, locally dolomitized; composed primarily of spongiostromate algal heads (including abundant oncoid forms). Sponges and minor accessory brachiopods indicate Late Silurian (Ludlovian-Pridolian) age in the study area. Equivalent to the S1 unit of Gilbert (1981) in the McGrath quadrangles. This unit is time transgressive elsewhere and includes rocks as young as early Early Devonian (Lochkovian) age in the Lime Hills area to the northeast (Clough and Blodgett, 1985, 1988, and 1992; Blodgett and Gilbert, 1992)

Sls Platy limestone (Early to early Late Silurian) Thin- to medium-bedded, laminated, dark-gray to darkbrown, platy lime mudstone having a strong petroliferous odor. Three-dimensional monograptid graptolites are moderately common in rocks of this unit. Coarsegrained limestone debris flows containing clasts of algal boundstone reef material common in uppermost part of unit, immediately below contact with overlying, prograding Sab unit. Contains graptolites and conodonts indicative of early Late Silurian (Wenlockian) age. Lowermost transitional beds with underlying Olss unit contain conodonts of late Early Silurian (late Llandoverian) age. Equivalent to the uOll unit of Gilbert (1981) in the McGrath quadrangle and the Paradise Fork Formation of Dutro and Patton (1982) in the Medfra quadrangle

Olss Tcherskidium-bearing limestone (Ashgillian, Late Ordovician) - Brown, medium- to thick-bedded skeletal lime packstone to wackestone containing locally abundant pentameroid brachiopods [Tcherskidium, smooth new genus aff. Tcherskidium, and Proconchidium (or Eoconchidium)] indicative of Late Ordovician (Ashgillian) age

Os Shale (Ordovician, undifferentiated) - Poorly exposed unit (mostly in frost boils) composed of brown and gray "chippy" shale, silty shale, and silicified limestone. No age definitive fossils known from this unit

Oab Dark-gray algal limestone (Early Ordovician) Medium- to thick-bedded, dark-gray to brown, algal thrombolites (boundstone) interbedded with light-grayweathering thin- to medium-bedded lime mudstone. Boundstone of this unit is comprised of spongiostromate algal buildups that are typically darker in color, thinner bedded, and have a different suite of accessory algal and biotic components than the algal boundstone of the overlying Sab unit. Contains trilobites indicative of an Early Ordovician age

Ols Burrow-mottled limestone (Early Ordovician) Thin- to medium-bedded, yellow-gray-weathering, dark-gray fresh, burrow-mottled lime mudstone. Peloidal mudstone locally common. Contains gastropods and conodonts indicative of an Early Ordovician age 


\title{
Use of Landsat MSS and TM Imagery to Improve Reconnaissance Geologic Mapping in the Ruby Quadrangle, West-Central Alaska
}

\author{
By Keith A. Labay, Frederic H. Wilson, and Kuuipo A. Burleigh
}

\section{Abstract}

By using Multispectral Scanner (MSS) and Thematic Mapper (TM) satellite images, the spatial relation of units JMtu (mafic, ultramafic, and sedimentary rocks, undivided) and PzZrqs (pelitic and quartzitic schist) of Wilson and others (1998) from the northeastern portion of the Ruby 1:250,000-scale quadrangle geologic map was further defined. The MSS image was first analyzed using spectral signatures to separate and highlight pixels associated only with the units of interest. This approach was ineffective at separating the units from areas of the image with similar spectral signatures, but it did show that unit JMtu and associated areas consistently had a high brightness value, while unit PzZrqs and associated areas consistently had a low brightness value. Consequently, a new approach was developed using spectral enhancement to emphasize the differences between these high- and lowbrightness areas. Once the TM image was obtained, the spectral signature separation and spectral enhancement approaches were again tested, but the results were similar to those found using the MSS image. By using the results from the spectral enhancement of the MSS image in combination with current ground-truth data, the locations of units JMtu and PzZrqs in the Ruby quadrangle were reinterpreted.

\section{Introduction}

The use of remote sensing data to identify geologic units in areas that have been poorly investigated can be an effective way of refining the boundaries of known units and showing the locations of previously unknown outcrops. Through processing of a Landsat Multispectral Scanner (MSS) image and a Landsat Thematic Mapper (TM) image, we hope to resolve questions about the geology of the Ruby 1:250,000-scale quadrangle. These questions involve the location of two rock units in the northeastern part of the Ruby quadrangle (fig. 1) and their relation to each other. Unit JMtu of Wilson and others (1998) consists of undivided Jurassic to Mississippian mafic, ultramafic, and sedimentary rocks from the Tozitna assemblage south of the Kaltag fault. We believed this unit might not be as extensive in the northeast part of the quadrangle as had been previously mapped (Dusel-Bacon and others, 1996) and that it would be found mainly capping ridges (R.M. Chapman, oral commun., 1998, cited in Wilson and others, 1998). Rock unit PzZrqs of Wilson and others (1998) consists of middle to early Paleozoic and (or) possibly Late Proterozoic(?) pelitic and quartzitic schist from the Ruby metamorphic complex. Our goals were to enhance the images through processing to sufficiently distinguish these units of interest and to determine their spatial relation more accurately.

\section{MSS and TM Image Properties}

The Landsat MSS image that was analyzed was recorded September 8, 1974. It showed the majority of the Ruby quadrangle along with associated portions of the Medfra, Kantishna River, and Mt. McKinley quadrangles. The image consisted of four separate bands covering different wavelengths of the electromagnetic spectrum. Each band is considered useful for detecting different types of surface features. Bands 1 and 2 covered the green and red portions of the visible spectrum from 0.50 to 0.70 micrometers $(\mu \mathrm{m})$. Band 1 will detect the green reflectance of vegetation, while band 2 is useful for detecting soil and geologic boundaries. Bands 3 and 4 covered part of the reflective infrared portion of the spectrum from 0.70 to $1.10 \mu \mathrm{m}$. Band 3 can emphasize land/water contrasts, while band 4 can penetrate haze and is often used for vegetation surveys (Schrader and Pouncey, 1997).

The Landsat TM image, obtained after analysis of the MSS image was completed, showed the entire Ruby quadrangle and neighboring portions of the Melozitna, Kantishna River, Medfra, and Mt. McKinley quadrangles. Unlike the MSS image, the TM image consisted of seven separate bands covering a much wider portion of the electromagnetic spectrum. Bands 1, 2, and 3 covered the blue, green, and red portions of the visible spectrum from 0.45 to $0.69 \mu \mathrm{m}$. Band 1 


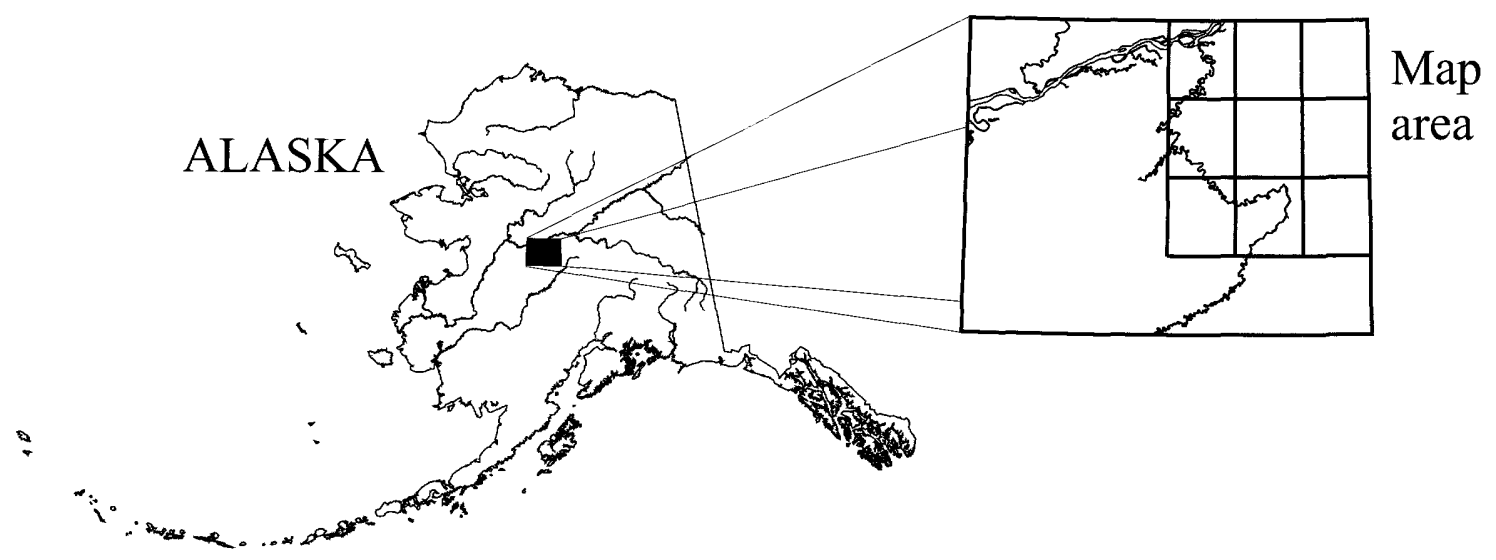

Figure 1. Index map of the Ruby quadrangle.

can show the difference between soil and vegetation, whereas the green and red bands have the same detection characteristics as they did in the MSS image. Band 4 covered part of the reflective infrared wavelengths from 0.76 to $0.90 \mu \mathrm{m}$ and had the same use as band 3 in the MSS image. Portions of the mid-infrared wavelengths are covered by band 5 from 1.55 to $1.74 \mu \mathrm{m}$ and band 7 from 2.08 to $2.35 \mu \mathrm{m}$. Band 5 can distinguish between clouds, ice, and snow, whereas band 7 is important for discriminating between geologic rock types and soil boundaries. Band 6 covered part of the thermal infrared wavelengths from 10.40 to $12.50 \mu \mathrm{m}$ and can detect areas of geothermal activity (Schrader and Pouncey, 1997).

\section{Spectral Signature Separation}

The initial processing approach involved using the ERDAS IMAGINE software package to manipulate the MSS image and highlight the areas where units JMtu and PzZrqs occur by separating their spectral signatures from the other signatures in the image. To accomplish this, areas of the image were selected where we were confident of the map-unit assignments on the published geologic map. These areas of groundtruth data were used to evaluate the effectiveness of various image-processing techniques for distinguishing the geologic map units of interest. Several different techniques were tested to determine their suitability for accomplishing this task, including principal components analysis, unsupervised classification, signature alarm, generating thresholds, and the use of indices (Schrader and Pouncey, 1997).

Principal components analysis is designed to make an image more visually interpretable by creating new image layers. The first layer or image accounts for as much of the variability in the image as possible, and each successive layer accounts for an additional component of the variability. With this method it can be possible to find subtle patterns hidden in the original image (Schrader and Pouncey, 1997). However, no patterns were found to correspond with the two units of interest.

Initiating an unsupervised classification allows the software to take pixels from an image and assign them to different classes. These software algorithms group together pixels from the image based on the clustering of their spectral signatures. The final output of this process consists of a new one-layer image and accompanying signature file. The latter contains relevant information about the new classes such as their names and the colors assigned to them. If classes had been created based on the pattern recognition skills of the user, then the classification process would have been considered "supervised" because the signature file used to create the one-layer image would not have been defined by the software (Schrader and Pouncey, 1997). The unsupervised classification was performed anticipating that separate classes for units JMtu and PzZrqs might be created. These classes could then be separated from the other classes created through "editing" of the signature file and raster attributes for the one-layer image.

The first type of editing involved selecting classes that appeared to have colors in the one-layer image that corresponded with the location of unit JMtu. A signature alarm could then be created to highlight the chosen classes by assigning a new, more prominent, color to all the pixels in those classes. It is also possible to create signature alarms without performing an unsupervised classification. In this case the pixels highlighted are chosen from a user-defined area of interest instead of a class.

The second type of editing focused on changing the opacity of all the classes in the raster attribute file so that initially all of the classes were transparent and the image was blank. Each class was then individually made opaque again so the locations of all the pixels in that class could be easily seen. Any class containing pixels corresponding with the locations of units JMtu or PzZrqs could be kept opaque while the other classes were changed back to transparent.

Either technique proved to be an effective way of making a specific class stand out from the rest of an image. These techniques also showed, however, that the classes identified in the signature file as corresponding to units JMtu and PzZrqs 
also corresponded to areas of the image that the geologic map (Wilson and others, 1998) showed could not be either of these units. This meant that separate classes for units JMtu or PzZrqs could not be distinguished because of the apparent similarities of their spectral signatures to these other areas. It was observed that the pixels in the class that included unit JMtu tended to conform to some of the boundaries shown for that unit on the geologic map, whereas none of the boundaries for unit PzZrqs were visible.

Generating thresholds provides a way to narrow the range of pixels assigned to a class by computing histograms displaying the distributions of the pixels for each class. The threshold for each histogram can then be lowered so that pixels from the tails of the histograms are eliminated. This is useful because these are the pixels that are most likely to have been incorrectly classified (Schrader and Pouncey, 1997). We thought that this process might allow us to reduce the size of the classes (defined by the previous unsupervised classification) enough to create a separate class for unit JMtu. Unfortunately, pixels were eliminated not only from unrelated areas but also from areas where the unit was known to be located.

Indices, or band ratios, are used to create new one-layer images by calculating a ratio of the values of pixels in different bands. Using these ratios, it is possible to bring out small differences between rock types that would otherwise be hidden among the spectral signatures from surrounding rocks and vegetation. The ERDAS IMAGINE software has 11 different preset indices available for use on satellite images (Schrader and Pouncey, 1997). Each index is considered useful for identifying different features of an image (table 1).

The six indices available for MSS images were tested on our original image but none could better define the relationship between units JMtu and PzZrqs. It is possible, however, to create band ratios other than those preset in the software. This is accomplished by using the spatial modeler to create small programs that perform mathematical operations, such as ratios, between the bands. These new ratio combinations were also tested on the original image, but none of the new images produced could show the spatial relation between the units of interest.

It was found, however, that the areas of the MSS image where unit JMtu was believed to occur consistently appeared as one of the regions of high brightness, whereas unit PzZrqs consistently appeared as one of the darker areas. This indicates that the rocks of unit JMtu tend to reflect most of the wavelengths of the electromagnetic spectrum covered by the bands of the MSS image while the rocks of unit PzZrqs tend to absorb most of those wavelengths.

\section{Spectral Enhancement}

Based on these consistent reflection and absorption characteristics, the locations of the high-brightness and lowbrightness regions, containing units JMtu and PzZrqs, could be used to provide information about the spatial relation of the units once the differences between the regions had been enhanced. This had the advantage of avoiding the problems associated with separating the units from areas with similar spectral signatures. However, it had the disadvantage of not providing definitive information about the locations of the units throughout the entire image. The techniques that proved most effective in creating an image showing these highand low-brightness regions included selecting the appropriate band combinations, histogram equalization, and adjusting the brightness and contrast.

Setting the band combination is a simple way of altering an image so that it is displayed using only those bands that have been found to contain useful information. Determining which bands will be the most useful can be accomplished by looking at the spectral profiles of areas of interest in the image. These spectral profiles help identify which bands contain the highest and lowest pixel values in the selected areas. An image displayed using those bands will have the greatest contrast due to the wide gap between the highest and lowest value pixels. For this particular image it was found that MSS bands 2,3 , and 4 assigned as red, green, and blue in the displayed image provided the best contrast between the high- and lowbrightness areas.

Histogram equalization is an automatic function that performs a nonlinear contrast stretch on the pixels comprising the three bands of the image being displayed. First, the average number of pixels per bin in the original histogram (fig. 2 dotted line) is calculated. Then, any bin that is smaller than the average is grouped with other small bins to create a larger bin closer to the average (fig. 2). Bins with more pixels than the average are stretched over the wider display range created by the grouping of the smaller bins (fig. 2). Contrast is thus decreased for values below the average, and it is increased for values above the average (Schrader and Pouncey, 1997). Histogram equalization proved useful in increasing the contrast between high- and low-brightness areas when the contrast provided by the band combination was not sufficient to define clear boundaries.

Adjusting the brightness and contrast is the final technique that allowed greater MSS image interpretation. A slight reduction of brightness level accompanied by a slight increase in contrast, each about five percent, is all that was necessary to enhance the image so that the boundaries between the highbrightness and low-brightness regions were better defined.

\section{Visually Interpreting the MSS Image}

Based on the different colors present in the image, and the corresponding variations in spectral signatures associated with them, there were two high-brightness and three low-brightness spectral types that could be defined. They were designated high-brightness type one (HB1) and type two (HB2), and lowbrightness type one (LB1), type two (LB2), and type three 
Table 1. Programmed indices in ERDAS IMAGINE.

\begin{tabular}{|c|c|c|c|}
\hline Preset indicia & Availability & Formula & Potential use \\
\hline $\mathrm{IR} / \mathrm{R}$ & MSS or TM images & Infrared band / Red band & $\begin{array}{l}\text { Highlights pixels that reflect } \\
\text { strongly in infrared and } \\
\text { weakly in red. }\end{array}$ \\
\hline SQRT (IR / R) & MSS or TM images & Sqrt (Infrared band / Red band) & $\begin{array}{l}\text { Reduces highlighting of } \\
\text { pixels that reflect strongly } \\
\text { in infrared and weakly in } \\
\text { red. }\end{array}$ \\
\hline Vegetation Index & MSS or TM images & Infrared band - Red band & $\begin{array}{l}\text { Identify vegetation (Schrader } \\
\text { and Pouncey, 1997). }\end{array}$ \\
\hline $\begin{array}{l}\text { Normalized Difference } \\
\text { Vegetation Index (NDVI) }\end{array}$ & MSS or TM images & $\begin{array}{l}\text { (Infrared band - Red band) / } \\
\text { (Infrared band + Red band) }\end{array}$ & $\begin{array}{l}\text { Identify vegetation (Schrader } \\
\text { and Pouncey, 1997). }\end{array}$ \\
\hline $\begin{array}{l}\text { Transformed NDVI } \\
\text { (TNDVI) }\end{array}$ & MSS or TM images & $\begin{array}{l}\text { Sqrt }(((\text { Infrared band }- \text { Red } \\
\text { band }) /(\text { Infrared band }+ \text { Red } \\
\text { band }))+0.5)\end{array}$ & $\begin{array}{l}\text { Identify vegetation (Schrader } \\
\text { and Pouncey, 1997). }\end{array}$ \\
\hline R31 & MSS images & MSS band 3 / MSS band 1 & $\begin{array}{l}\text { Highlights pixels that reflect } \\
\text { strongly in band } 3 \text { and } \\
\text { weakly in band } 1 .\end{array}$ \\
\hline Iron oxide & TM images & TM band 3 / TM band 1 & $\begin{array}{l}\text { Detect presence of iron oxide } \\
\text { (Schrader and Pouncey, } \\
\text { 1997). }\end{array}$ \\
\hline Clay minerals & TM images & TM band 5 / TM band 7 & $\begin{array}{l}\text { Detect presence of clay } \\
\text { minerals (Schrader and } \\
\text { Pouncey, 1997). }\end{array}$ \\
\hline Ferrous minerals & TM images & TM band 5 / TM band 4 & $\begin{array}{l}\text { Detect presence of ferrous } \\
\text { minerals (Schrader and } \\
\text { Pouncey, 1997). }\end{array}$ \\
\hline Mineral composite & TM images & $\begin{array}{l}\text { (TM band } 5 / \mathrm{TM} \text { band } 7 \text { ), (TM } \\
\text { band } 5 \text { / TM band } 4 \text { ), (TM } \\
\text { band } 3 \text { / TM band } 1 \text { ) }\end{array}$ & $\begin{array}{l}\text { Three ratios combined to } \\
\text { create color image } \\
\text { routinely used to identify } \\
\text { mineral types (Schrader } \\
\text { and Pouncey, 1997). }\end{array}$ \\
\hline Hydrothermal composite & TM images & $\begin{array}{l}\text { (TM band } 5 \text { / TM band 7), (TM } \\
\text { band } 3 \text { / TM band 1), (TM } \\
\text { band } 4 \text { / TM band } 3 \text { ) }\end{array}$ & $\begin{array}{l}\text { Three ratios combined to } \\
\text { create color image } \\
\text { highlighting areas of } \\
\text { hydothermal alteration } \\
\text { (Schrader and Pouncey, } \\
\text { 1997). }\end{array}$ \\
\hline
\end{tabular}

(LB3). Once the boundaries of these five spectral types had been determined, the geologic map (Wilson and others, 1998) was used to determine the units that fell within these boundaries (table 2).

\section{Processing the TM Image}

After concluding our analysis of the MSS image, there was still the possibility that the more specific results we had originally sought, concerning the spatial relation of units JMtu and PzZrqs, could be derived from the recently obtained TM image using spectral signature separation. Even if these results were still inconclusive, a comparison of the images using the spectral enhancement approach could still reveal new information about the high- and low-brightness regions. The spectral signature separation techniques used on the TM image were principal components analysis, unsupervised classification, signature alarm, generating thresholds, and indices. These were the techniques that had seemed the most promising when dealing with the MSS image.

While testing the first techniques, it became apparent that processing the entire TM image would require more time than the MSS image and storing the images created would use larger amounts of computer memory. These problems were due to the larger amounts of spectral data contained in the TM image. This problem was overcome by creating a subset 

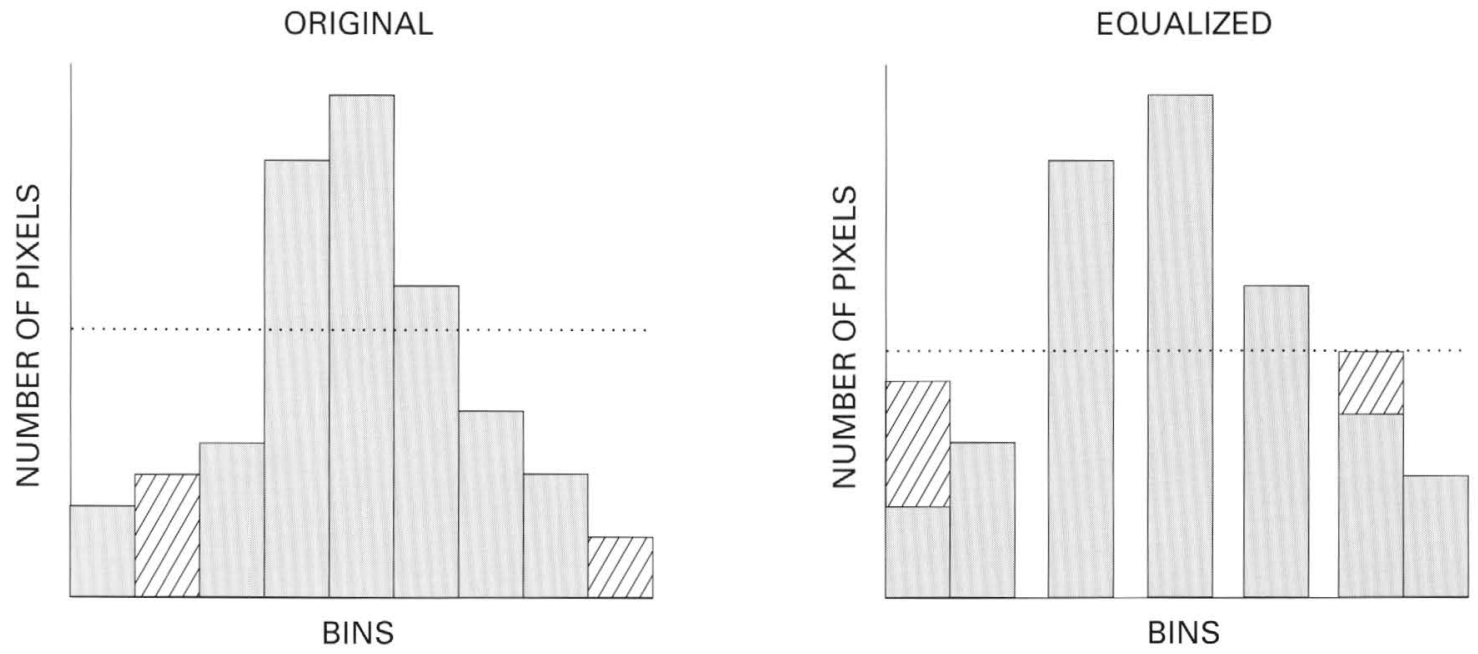

Figure 2. The original histogram shows the relationship of the bins to the dotted line representing the average number of pixels per bin. The equalized histogram shows how the striped bins have now been grouped with other bins that were smaller than the average to create one new larger bin closer to the average. The spaces between those bins that were larger than the average show how they have been stretched over the wider display range made available by grouping the smaller bins. This results in increased contrast for pixels above the average.

Table 2. Visually interpreted spectral type characteristics.

\begin{tabular}{ccc}
\hline Spectral type & \multicolumn{1}{c}{ Color } & Brief description \\
\hline HB1 & Blue & $\begin{array}{c}\text { Corresponds with units JMtu, TKvi, DCd, CZw, Kg, Jmab, Pig, Ynqd, and ZYnm all of } \\
\text { Wilson and others (1998). }\end{array}$ \\
HB2 & Orange & $\begin{array}{c}\text { Shows a strong correlation with mapped plutons of units TKg, TKgd, and TKiv from } \\
\text { Wilson and others (1998). }\end{array}$ \\
LB1 & Blue-green & $\begin{array}{c}\text { Corresponds with units PzZrqs, Pzrm, TKvi, TKi, Kk, JTrta, JPztm, TrMica, TrMtqp, } \\
\text { Oc, Ont, Spf, DSwc, DSl, PDsc, Ksm, Trsl, Trn, Tkvr, TKvr, ZYns, Zynm, and Zync } \\
\text { of Wilson and others (1998). }\end{array}$ \\
LB2 & Red & $\begin{array}{c}\text { Appeared as a distinctive red color in six mountainous areas, but could not be correlated } \\
\text { with any geologic units. }\end{array}$ \\
\hline LB3 & $\begin{array}{c}\text { Variety of } \\
\text { dark colors }\end{array}$ & $\begin{array}{c}\text { Corresponds with unit Qs containing unconsolidated surface sediments of Wilson and } \\
\text { others (1998). }\end{array}$ \\
\hline
\end{tabular}

of the image that still covered our areas of interest but was small enough to be processed more quickly. The processing of our subset image showed that, despite having a greater spectral range, it was still not possible to isolate units JMtu or PzZrqs from those units previously identified in the MSS image as having similar reflectance and absorption values.

By using the spectral enhancement techniques to show the boundaries of the high- and low-brightness regions in the TM image, an image that was comparable to the final MSS image could be created. The combination of bands 4, 5, and 7 assigned as red, green, and blue, histogram equalization, a two percent reduction in brightness, and seven percent increase in contrast created an image with the best contrast between the areas. Colors in the TM image appeared differently than they did in the MSS image, but it was possible to correlate them with the previously established spectral types and colors (table 3 ).

\section{Geologic Changes}

After processing of the TM image yielded results equivalent to those from the MSS image, our initial results from spectral enhancement of the MSS image continued to be used as a basis for geologic reinterpretation. The results of that analysis have led to two major changes being made in the Ruby quadrangle. On the original geologic map (Wilson and others, 1998) extensive outcrops of unit JMtu are shown in the northeast portion of the Ruby quadrangle (fig. 3). Based on the distribution of the high- and low-brightness regions in this area, however, many of these outcrops are now being interpreted as unit PzZrqs (fig. 4). The second change made involved unit Pzrm of Wilson and others (1998) (fig. 3). A portion of that unit that appeared as high-brightness type one is now being interpreted as indicating unit JMtu (fig. 4). 
Northeast Ruby quadrangle geologic mapping

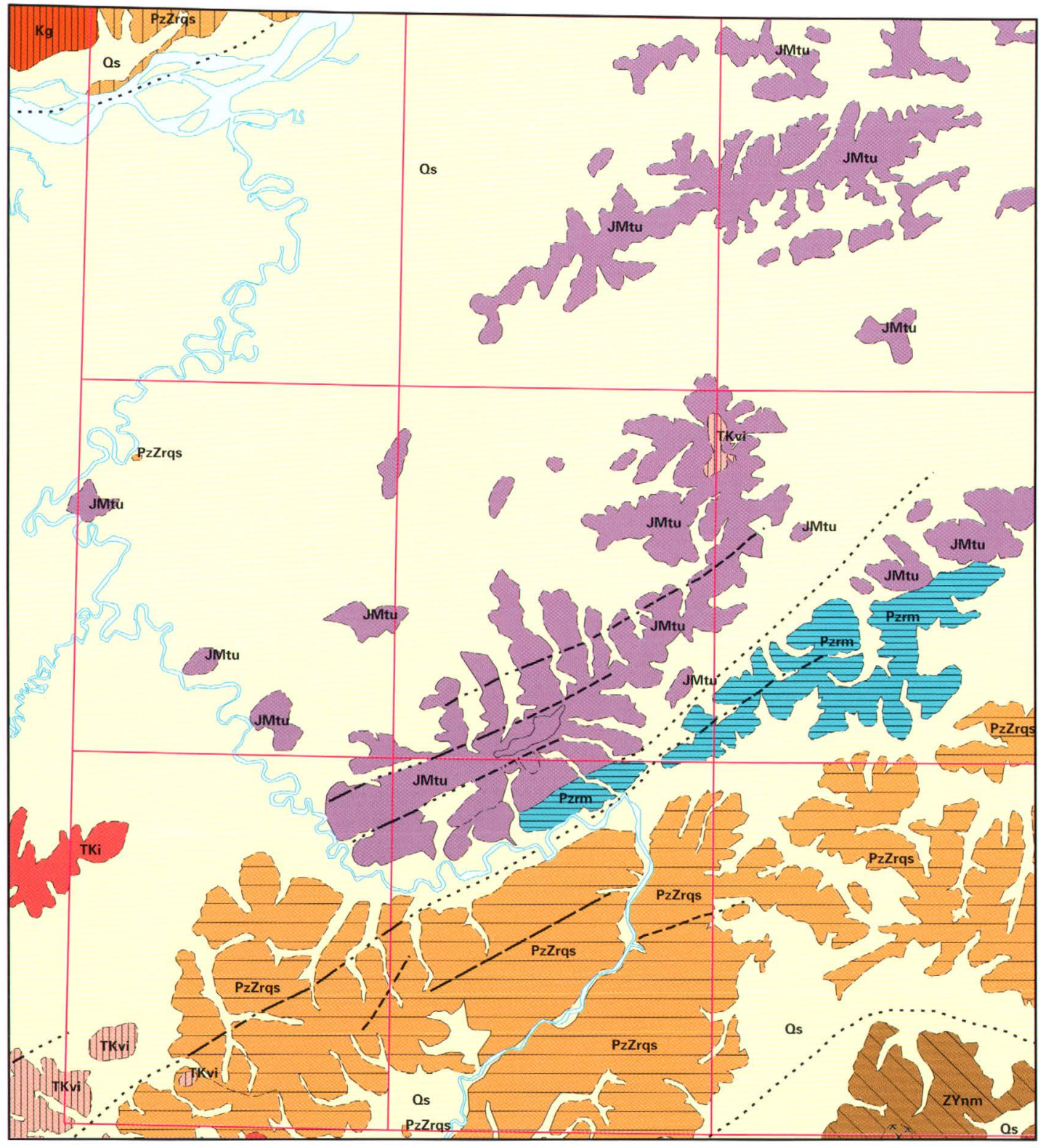

\section{Geologic units}

Water bodies

Qs Surficial deposits, undifferentiated

TKvi Andesite and related rocks

TKi Intrusive rocks, undivided

JMtu Mafic, ultramafic, and sedimentary rocks of the Tozitna sequence, undivided

PzZrqs Pelitic and quartzitic schist, Ruby metamorphic complex

Pzrm Marble, Ruby metamorphic complex

ZYnm Metamorphic basement rocks of the Nixon Fork sequence, undivided

See Wilson and others (1998) for complete unit descriptions

\section{Line symbols}

Stratigraphic contacts -- Certain

Stratigraphic contacts -- Approximate

Stratigraphic contacts -- Concealed

Faults -- Certain

Faults -- Approximate

Faults -- Inferred

Faults -- Concealed

Thrust faults, teeth on upper plate -- Certain

_._. Thrust faults, teeth on upper plate -- Approximate

A. A. Thrust faults, teeth on upper plate -- Concealed Shorelines

1:63,360-scale quadrangle outlines

Figure 3. Published interpretation (Wilson and others, 1998). 


\section{Northeast Ruby quadrangle geologic mapping}

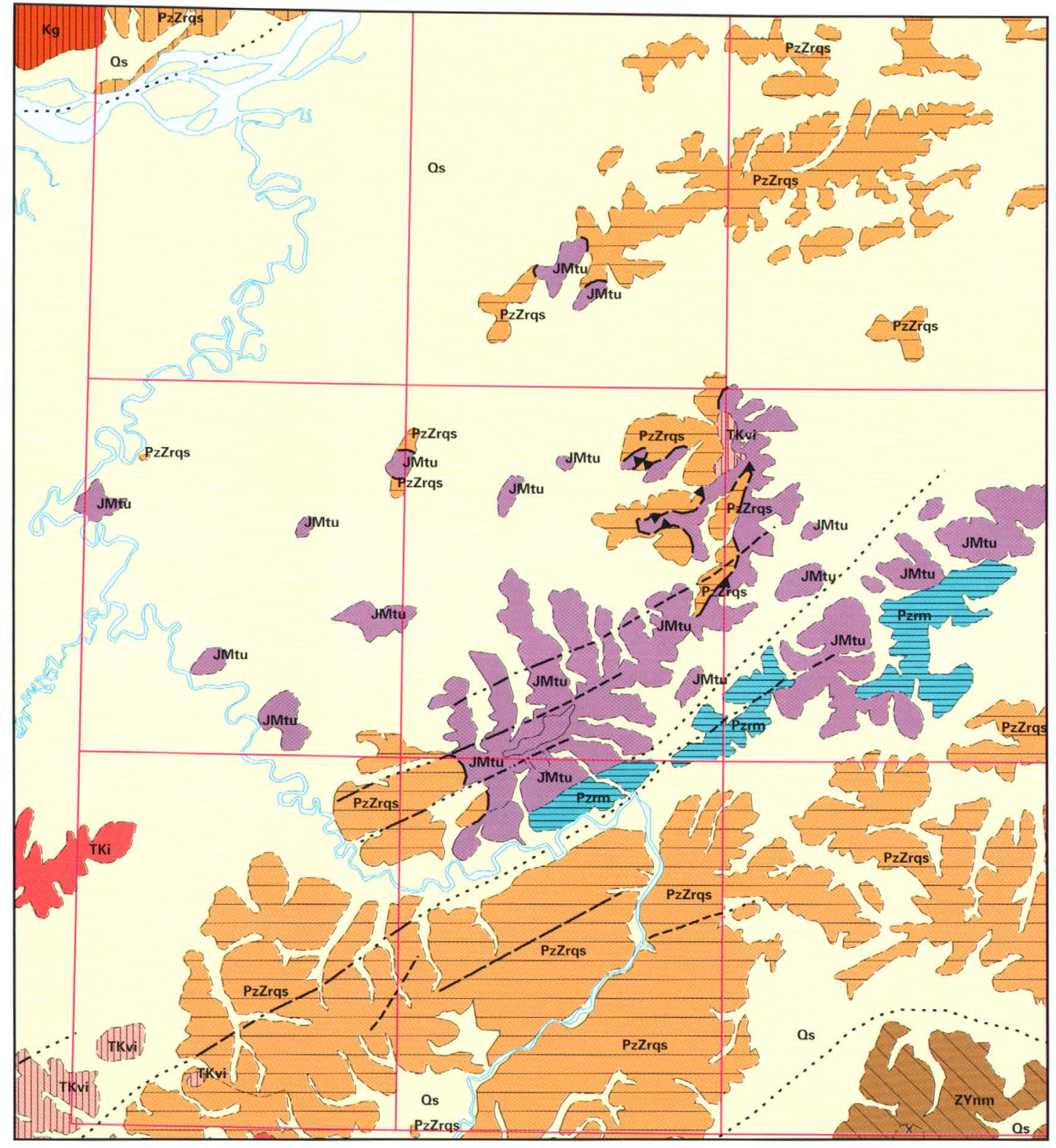

\section{Geologic units}

Water bodies

Qs Surficial deposits, undifferentiated

111010 TKvi Andesite and related rocks

TKi Intrusive rocks, undivided

JMtu Mafic, ultramafic, and sedimentary rocks of the Tozitna sequence, undivided

PzZrqs Pelitic and quartzitic schist, Ruby metamorphic complex

Pzrm Marble, Ruby metamorphic complex

ZYnm Metamorphic basement rocks of the Nixon Fork sequence, undivided

See Wilson and others (1998) for complete unit descriptions

\section{Line symbols}

Stratigraphic contacts -- Certain

Stratigraphic contacts -- Approximate

Stratigraphic contacts -- Concealed

- Faults -- Certain

- $\quad$ Faults -- Approximate

---- Faults -- Inferred

..... Faults -- Concealed

T_L Thrust faults, teeth on upper plate -- Certain

L_. Thrust faults, teeth on upper plate -- Approximate

.A. A. Thrust faults, teeth on upper plate -- Concealed Shorelines

1:63,360-scale quadrangle outlines 
Table 3. MSS to TM spectral type correlation.

\begin{tabular}{|c|c|c|c|}
\hline Spectral type & MSS color & TM color & Brief description \\
\hline HB1 & Blue & Red-orange & $\begin{array}{l}\text { Corresponds with units JMtu, TKvi, DCd, CZw, Kg, Jmab, Pig, Ynqd, } \\
\text { and ZYnm all of Wilson and others (1998). }\end{array}$ \\
\hline $\mathrm{HB} 2$ & Orange & Blue & $\begin{array}{l}\text { Shows a strong correlation with mapped plutons of units TKg, TKgd, } \\
\text { and TKiv from Wilson and others (1998). }\end{array}$ \\
\hline LB1 & Blue-green & Gray & $\begin{array}{l}\text { Corresponds with units PzZrqs, Pzrm, TKvi, TKi, Kk, JTrta, JPztm, } \\
\text { TrMica, TrMtqp, Oc, Ont, Spf, DSwc, DSl, PDsc, Ksm, Trsl, Trn, } \\
\text { Tkvr, TKvr, ZYns, Zynm, and Zync of Wilson and others (1998). }\end{array}$ \\
\hline LB2 & Red & $\begin{array}{l}\text { No } \\
\text { correlation }\end{array}$ & $\begin{array}{l}\text { Appeared as a distinctive red color in six mountainous areas, but could } \\
\text { not be correlated with any geologic units. }\end{array}$ \\
\hline LB3 & $\begin{array}{l}\text { Variety of } \\
\text { dark colors }\end{array}$ & $\begin{array}{l}\text { Variety of } \\
\text { dark to } \\
\text { light colors }\end{array}$ & $\begin{array}{l}\text { Corresponds with unit Qs containing unconsolidated surface sediments } \\
\text { of Wilson and others (1998). }\end{array}$ \\
\hline
\end{tabular}

\section{Conclusion}

The initial spectral signature separation approach of creating new images based on the Landsat MSS image that would exclusively show the locations of those rocks with a spectral signature matching that of units JMtu or PzZrqs proved to be unsuccessful. The consistent distributions shown by the highand low-brightness areas in those images, however, made it apparent that a more generalized approach to the problem could provide potentially useful information about the geology shown in the MSS image. Using this spectral enhancement approach may not allow different rock units to be distinguished exclusively by their spectral signatures, but a correlation with the existing ground-truth geologic data can allow the assignment of generalized spectral signatures to some rock units. After completing work on the MSS image, the spectral signature separation and spectral enhancement approaches were used on the recently obtained TM image. Our results were consistent with those derived from using the same approaches on the MSS image. Despite the difference in colors between the MSS and TM images produced by the slightly different spectral enhancement approaches, it was possible to correlate the high- and low-brightness areas of the TM image with the spectral types from the MSS image without any significant differences being found. This meant that the results from the spectral enhancement processing of the MSS image could continue to be used as a basis for geologic reinterpretation.

By correlating unit JMtu with the occurrences of HB1 spectral type from the MSS image, it appears that it is somewhat less extensive than shown (fig. 3) on the geologic map (Wilson and others, 1998) and does, in fact, often occur along the tops of ridges (fig. 4) as reported by R.M. Chapman (oral commun., 1998, cited in Wilson and others, 1998). Nearby areas of high-brightness type one (HB1) may also indicate additional outcrops of unit JMtu not on the map (Wilson and others, 1998). These areas of HB1 pixels were in locations that had been mapped as units PzZrqs and Pzrm, which typically were of low-brightness type one (LB1). Only within one section of unit Pzrm, however, were we confident enough in the existing ground-truth data to interpret the corresponding area of HB1 as indicating unit JMtu (fig. 4). In effect, the spectral enhancement approach has yielded an outcome that the original spectral signature separation approach failed to do and therefore allowed us to meet our original goal of determining the spatial relation of units JMtu and PzZrqs. As geologic work in the Ruby quadrangle and nearby areas continues, we hope that the image processing and geologic reinterpretations performed for this project will continue to prove useful.

\section{References Cited}

Dusel-Bacon, Cynthia, Doyle, E.O., and Box, S.E., 1996, Distribution, facies, ages, and proposed tectonic associations of regionally metamorphosed rocks in southwestern Alaska and the Alaskan Peninsula: U.S. Geological Survey Professional Paper 1497-B, 30 p., 2 plates, scale 1:1,000,000.

Schrader, S., and Pouncey, R. eds., 1997, ERDAS Field Guide, (4th ed.): Atlanta, ERDAS, Inc.

Wilson, F.H., Dover, J.H., Bradley, D.C., Weber, F.R., Bundtzen, T.K., and Haeussler, P.J., 1998, Geologic map of central (Interior) Alaska: U.S. Geological Survey Open-File Report 98-133, 76 p., 3 sheets, scale $1: 500,000$.

Reviewers: M. Compton, J. Power 


\title{
Holocene Vegetation History of the Northern Kenai Mountains, South-Central Alaska
}

\author{
By Thomas A. Ager
}

\section{Abstract}

Analysis of pollen assemblages from a 103-cm-thick peat deposit exposed near Tern Lake, Kenai Peninsula, Alaska, provides the first radiocarbon-dated postglacial vegetation history for the Kenai Mountains. The peat overlies glacial till deposited during the late Wisconsin glaciation. A peat sample from near the base of the deposit provides a radiocarbon age of 9,310 \pm 200 yr B.P., the first minimum age for deglaciation of the interior valleys of the Kenai Mountains. Earliest postglacial vegetation recorded at this site was composed of shrub birch (Betula nana), alder (Alnus), willow (Salix), grasses (Poaceae), wormwood (Artemisia), various herbs, and ferns (Polypodiaceae type). Another common shrub in this early postglacial vegetation was soapberry (Shepherdia canadensis), a shrub now uncommon on the Kenai Peninsula. Between about 8,600 and 7,800 yr B.P., soapberry shrubs were abundant in the area, along with ferns and alders. Soon after that, the alder population increased rapidly, soapberry shrubs diminished in importance, and boreal spruce (probably white spruce, Picea glauca) began to invade the western portals of the major valleys. The boreal spruce spread eastward into the mountain valleys from the northern Kenai Lowlands, probably along with paper birch trees (Betula papyrifera). By about 5,600 yr B.P., if not earlier, boreal spruce trees were colonizing the Tern Lake area. By about 2,900 yr B.P., small but significant amounts of pollen of mountain hemlock (Tsuga mertensiana) began appearing in the pollen assemblages at this site, and soon thereafter, spruce pollen percentages increased substantially. This rise in spruce and mountain hemlock pollen percentages probably reflects the colonization of the eastern and northern valleys of the Kenai Mountains by Sitka spruce (Picea sitchensis) and mountain hemlocks from sources in Prince William Sound to the east. The local vegetation seen in the Tern Lake area today developed within the past ca. 2,500 years. This vegetation is a rich mixture of boreal, (interior continental climate) and coastal-adapted (maritime climate) tree, shrub, and herb species. This blending of interior and coastal floras reflects a rather abrupt transitional boundary near Tern Lake between the maritime climate of the eastern and southern coasts of the Kenai Peninsula, and the more continental climate of the Kenai Lowland and northwestern Kenai Mountains. Many boreal plant species reach their easternmost range on the Kenai Peninsula near Tern Lake, and their further expansion appears to be limited by maritime climate near the coast.

\section{Introduction}

This paper presents the results of analyses of fossil pollen and spores obtained from a peat deposit exposed in a roadcut near Tern Lake (fig. 1, site 5; fig. 2), within a glaciated valley in the central Kenai Mountains. The record is significant because it is the first radiocarbon-dated postglacial vegetation record from the Kenai Mountains to be published. The pollen record, when viewed in the context of the regional postglacial vegetation history, explains when, and from what seed sources the present rich mixture of boreal and coastal vegetation came into being within the Kenai Mountains. The record is also significant because the basal age of the peat deposit provides the first minimum date for deglaciation of the main valleys of the central Kenai Mountains. Unlike the Kenai Lowlands to the west, the Wisconsin glacial and deglaciation history of the Kenai Mountains is poorly known. Finally, the Tern Lake peat record is unique in south-central Alaska because of the unusual character of its early postglacial vegetation, characterized by an abundance of soapberry shrubs. Interestingly, these locally abundant shrubs apparently failed to spread much farther eastward and southward from the Tern Lake area during the Holocene.

\section{Previous Work}

Postglacial histories of vegetation development of the Cook Inlet region have been described for the Anchorage area (Ager and Brubaker, 1985; fig. 1, site 6), the Hidden Lake area of the northern Kenai Lowland (Ager, 1983; fig. 1, site 


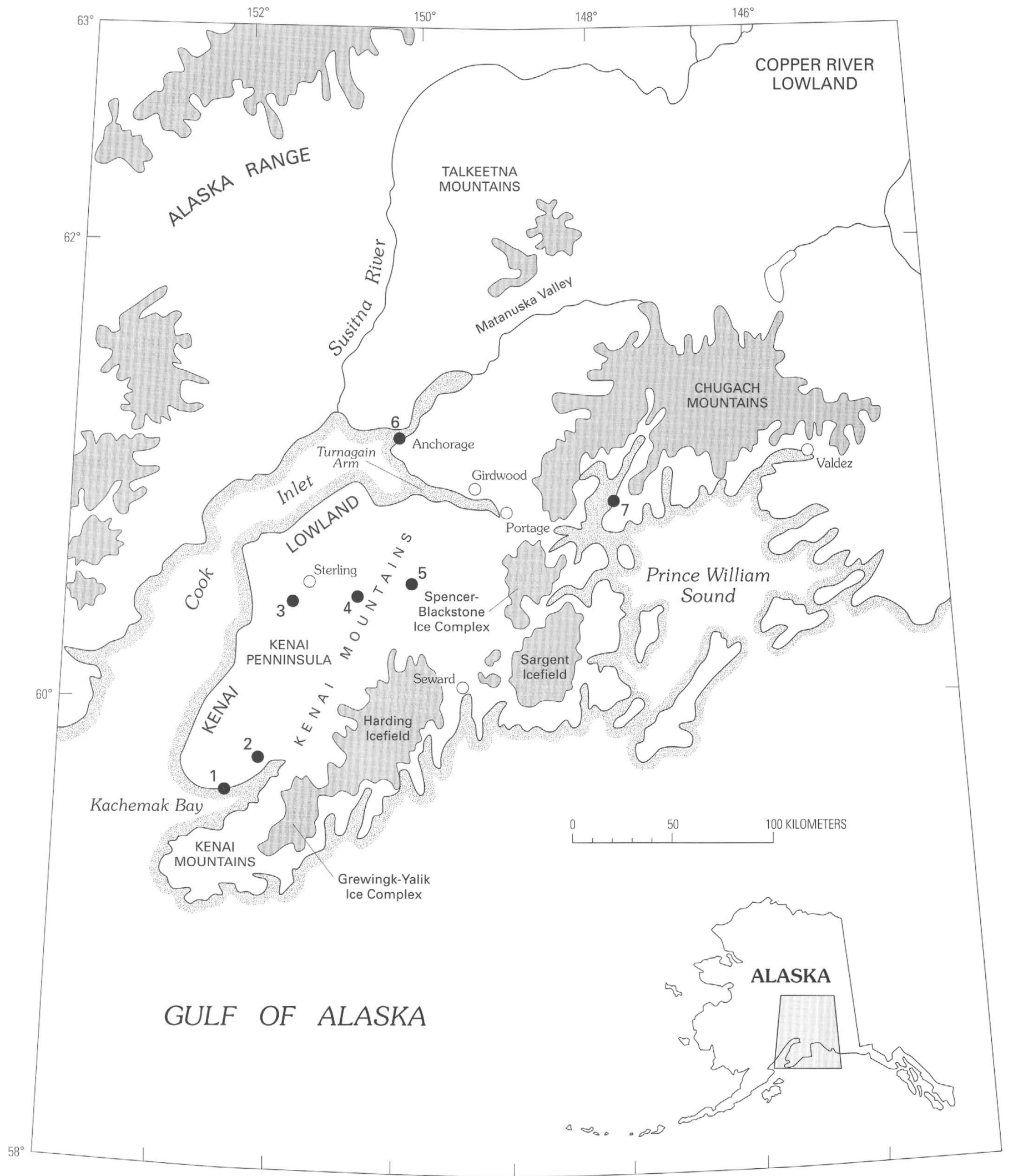

Figure 1. Map of south-central Alaska showing Cook Inlet, Kenai Peninsula, and Prince William Sound. Sites and features discussed in the text are shown: Kenai Lowland, Kenai Mountains, Turnagain Arm, and seven numbered sites: Kachemak Bay sites: (1) Homer peat section, (2) Circle Lake; Kenai Lowland sites: (3) Longmere Lake, (4) Hidden Lake; Kenai Mountains site: (5) Tern Lake peat section; Anchorage site: (6) Point Woronzof; western Prince William Sound site, (7) Golden. Climate data in table 1 are from meteorological stations at Sterling, Cooper Landing, Seward, and Portage. 


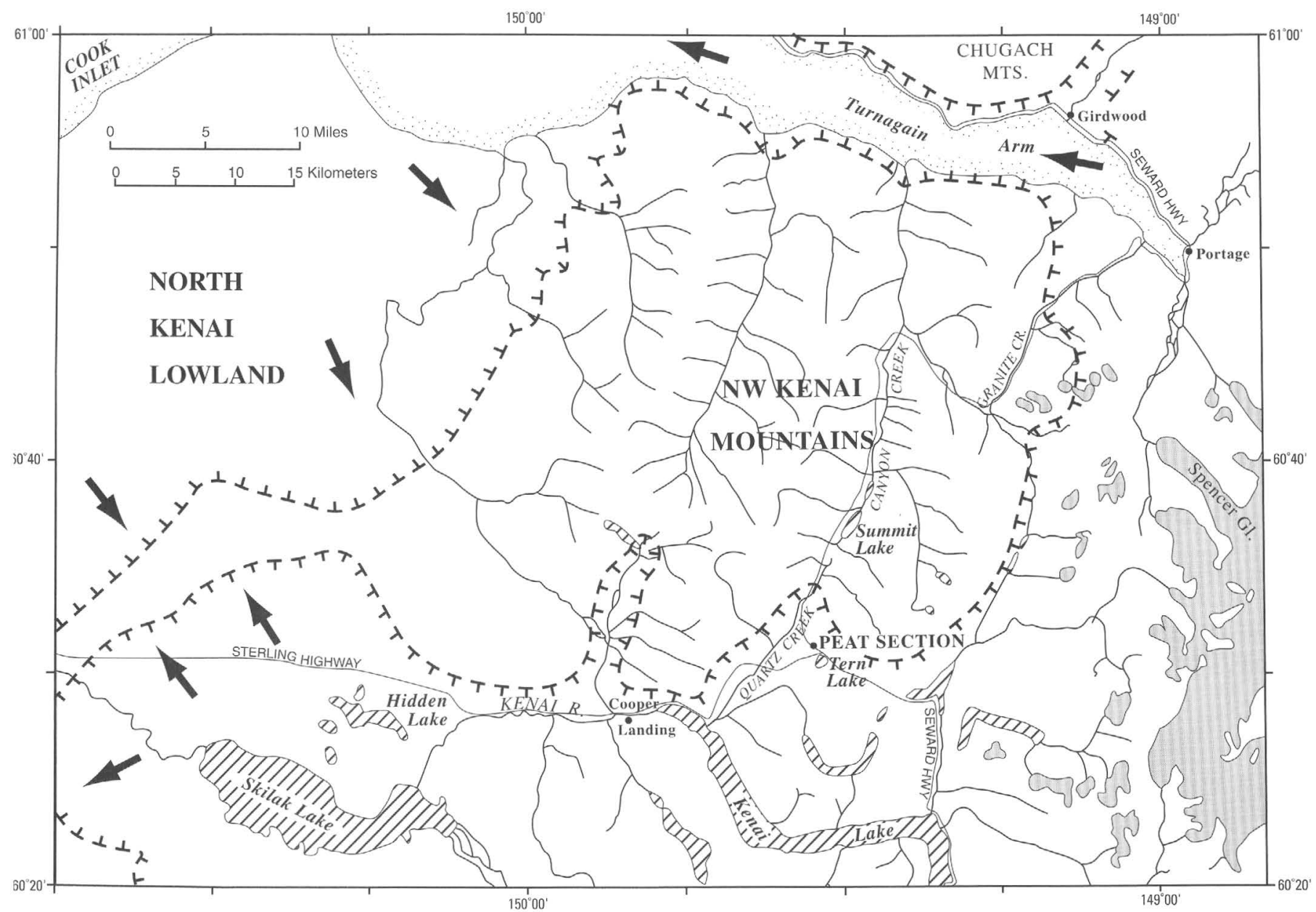

Figure 2. Map of northern Kenai Peninsula showing approximate maximum extent of late Wisconsin glacial ice (Moosehorn stade, Naptowne glaciation of Karlstrom, 1964; Reger and Pinney, 1996, 1997; Reger and others, 1996) in upper Cook Inlet. Maximum positions of late Wisconsin ice is shown with a hatchured dashed line. Major ice flow directions are shown with arrows. The Tern Lake peat section, Hidden Lake, Summit Lake, Girdwood, Portage, and Cooper Landing are shown; all are places mentioned in the text.

4); and the Kachemak Bay area of the southern Kenai Peninsula (Ager, 2000; fig. 1, sites 1 and 2). In addition, several postglacial pollen records from peat cores were obtained from the Kenai Peninsula and Turnagain Arm during the 1950's by C.J. Heusser (1960). Heusser's sites in those areas lack radiocarbon dates upon which to base a chronology of vegetation development, however, and therefore the usefulness of those records for the purposes of this paper are limited. However, some of Heusser's pollen records from peat cores from Prince William Sound, east of Kenai Peninsula, include some radiocarbon ages and therefore provide a basis for understanding the Holocene vegetation history of that adjacent area (Heusser, 1955, 1960, 1983, 1985; fig. 1, site 7). Heusser's pollen evidence from the Prince William Sound area indicates that coastal forest vegetation developed there during the late Holocene, after a long-delayed colonization. The seed sources for coastal forests established in Prince William Sound were forests established in southeastern Alaska during early postglacial time (Heusser, 1985; Peteet, 1986, 1991).

\section{Past and Present Glaciers on Kenai Peninsula}

Today, glaciers cover $4,800 \mathrm{~km}^{2}$ of the Kenai Mountains. Most of the glacial ice is concentrated in four major glacier complexes: the Harding icefield, the Grewingk-Yalik ice complex in the southern Kenai mountains, the Sargent icefield, and the Spencer-Blackstone ice complex in the northeastern mountains (fig. 1). Relatively few glaciers, all of them small, now exist in the northwestern Kenai Mountains, because most moisture from the Gulf of Alaska air masses is intercepted by the seaward portions of the mountains. Mean annual snowfall exceeds $10 \mathrm{~m}$ over the present-day icefields near the coast, but drops to about $2.5 \mathrm{~m}$ in the northwestern Kenai Mountains (Hartman and Johnson, 1978). The altitude of snowline rises abruptly from the southern and eastern coasts, where snowline is near $450 \mathrm{~m}$, to the northwest Kenai Mountains, where snowline is above 1,000 $\mathrm{m}$ (Péwé, 1975, p. 11). Most of the peaks in 
the Kenai Mountains are 800 to $1,500 \mathrm{~m}$ in altitude.

During the late Wisconsin glaciation, icefields expanded to cover most of the southern and northeastern Kenai Mountains. However, according to Karlstrom (1964), glaciers were not extensive in the northwestern Kenai Mountains, even during the maximum late Wisconsin glaciation. At that time, ice flowed from the northeastern Kenai Mountains into upper Turnagain Arm and from the southern Kenai Mountains into the eastern Kenai Lowland (fig. 1, fig. 2).

The most detailed mapping of Pleistocene-age moraines and glacial deposits on the Kenai Peninsula has been done in the Kenai Lowland (e.g., Karlstrom, 1964; Reger and others, 1996; Reger and Pinney, 1996, 1997). Relatively little detailed mapping and interpretation of glacial deposits has been done in the Kenai Mountains, except in the northeast and outer coastal areas, where most studies have focused on Holocene glacial history (Karlstrom, 1964; Crossen, 1992; Wiles and Calkin, 1990, 1993, 1994; Wiles and others, 1999). A generalized glaciation map by Karlstrom (1964, plate 1) remains the best available information on Pleistocene glacial history of the northwestern Kenai Mountains. Karlstrom's map shows that glacial ice filled the valleys to the west and south of the Tern Lake area during the maximum late Wisconsin glaciation. His map indicates that ice did not extend far into the Quartz Creek-Canyon Creek valley north of Tern Lake (fig. 2) at that time. With glacial ice blocking both the south and north ends of the Quartz Creek-Canyon Creek valley and the northern Granite Creek valley, it is likely that, at least occasionally, lake water was impounded in these valleys during the major late Wisconsin glacial advances.

The northwestern Kenai Mountains were extensively glaciated several times earlier in Pleistocene time (Karlstrom, 1964). However, the minimal extent of ice during the late Wisconsin glaciation (ca. 26,000-10,000 yr B.P. in this region) suggests that the area may have been an important refugium for at least alpine tundra plants and animals during that event. The Caribou Hills north of Kachemak Bay and other areas along the western edge of the Kenai Lowland may also have served as significant refugia (fig. 1, fig. 2; Karlstrom, 1964; Reger and Pinney, 1996; Ager, 2000). However, none of these potential refugia have yet been adequately explored for fossil assemblages dating to full glacial time.

\section{Deglaciation Chronology}

Radiocarbon dates from a Hidden Lake sediment core (fig. 1, site 4), $36 \mathrm{~km}$ west of Tern Lake, indicate that deglaciation in that area began more than 13,700 yr B.P. (Rymer and Sims, 1982; Ager, 1983). The late Wisconsin glaciation of the Cook Inlet region was a complex event consisting of at least four significant glacial advances. Between advances, ice fronts that had reached the region's lowlands during previous advances stagnated or partially receded (Karlstrom, 1964;
Reger and Pinney, 1996, 1997). The final glacial advance (Elmendorf or Tanya stade) is believed to have begun after $14,000 \mathrm{yr}$ B.P. and ended before 9,500 yr B.P. (Reger and Pinney, 1996). This advance was a relatively minor event near Hidden Lake, and ice appears to have reached only the eastern end of the lake (Reger and others, 1996). Icefields may have persisted longer within the Kenai Mountains than in the Kenai Lowland, where precipitation is lower. Therefore the deglaciation phase of the Elmendorf stade may vary from area to area.

The deglaciation chronology within the Kenai Mountains is poorly documented, but a few basal peat dates from western Prince William Sound and the outer coastal valleys of the Kenai Peninsula suggest that deglaciation was not extensive until earliest Holocene time (Heusser, 1960, 1983, 1985; Wiles and Calkin, 1994; Reger and others, 1996; Schmoll and others, 1999; Ager, 1983, 2000). Given the paucity of radiocarbondated deposits, the apparent late deglaciation of the Kenai Mountains should be viewed with some skepticism. Radiocarbon dates as old as $11,820 \pm 560 \mathrm{yr}$ B.P. (organic pond sediments) from northeastern Prince William Sound (Reger, 1991) indicate that the fiord at the Port of Valdez was deglaciated much earlier than previous credible dates from the coastal region suggested (Ager, 1983). A basal peat date from the north central Chugach Mountains indicates that some mountain valleys in southern Alaska were free of glacial ice by $13,900 \pm 400$ yr B.P. (Sirkin and Tuthill, 1987).

It is possible that the early Holocene radiocarbon dates currently available from the Kenai Mountains may simply be a record of the onset of peat deposition, rather than representing a closely limiting date for deglaciation. Compilations of radiocarbon dates on basal peats from the Kenai Peninsula suggests that at most sites, peat deposition began less than $10,000 \mathrm{yr}$ B.P. in the region (Karlstrom, 1964; Reger and others, 1996). In the future, the deglaciation chronology of the Kenai Mountain valleys can best be resolved by the radiocarbon dating of basal organic-bearing sediments from lakes in the region. Accumulation of organic material in lake basins is likely to have begun earlier than peat accumulation on barren soils at most sites.

Glacial advances during the Holocene that have been documented from several areas of the Kenai Peninsula and the Chugach Mountains north of Turnagain Arm (e.g., Wiles and Calkin, 1990, 1994; Schmoll and others, 1999; Crossen, 1992; Reger and Pinney, 1996, 1997) may have influenced regional vegetation. The most likely influence of colder and (or) wetter climates (with greater snowfall) would be to lower altitudinal limits of tree growth. However, minor changes in tree-line altitude are probably not detectable in pollen records from lowland sites such as the Tern Lake peat section. Higher altitude sites may provide more sensitive vegetation records responding to Holocene climate changes. However, an increase in outwash deposition in the valley floors during glacial advances and retreats may result in detectable lowland vegetation changes. 
Table 1. Climate data from four meteorological stations from the Kenai Peninsula and upper Turnagain Arm.

[Portage and Seward are within the maritime climate zone. Cooper Landing is in the Kenai River valley in the western Kenai Mountains, $24 \mathrm{~km}$ west of the Tern Lake area. Cooper Landing's climate is transitional but is influenced by maritime air masses to a greater degree than sites in the Kenai Lowland. Sterling is located in the northern Kenai Lowland, about $65 \mathrm{~km}$ west of Tern Lake. Sterling's climate is transitional, but its position in the precipitation shadow of the Kenai Mountains results in a more continental climate influence than at the other sites listed here. Climate data are from Leslie (1989)]

\begin{tabular}{|c|c|c|c|c|c|c|c|c|}
\hline Locality & Latitude & Longitude & Altitude & $\begin{array}{l}\text { Years of } \\
\text { record }\end{array}$ & $\begin{array}{c}\text { Mean } \\
\text { January } \\
\text { temperature }\end{array}$ & $\begin{array}{c}\text { Mean } \\
\text { July } \\
\text { temperature }\end{array}$ & $\begin{array}{c}\text { Mean } \\
\text { annual } \\
\text { temperature }\end{array}$ & $\begin{array}{c}\text { Mean } \\
\text { annual } \\
\text { precipitation }\end{array}$ \\
\hline Sterling & $60^{\circ} 32^{\prime} \mathrm{N}$ & $150^{\circ} 45^{\prime} \mathrm{W}$. & $76 \mathrm{~m}$ & $1954-1961$ & $-12.4^{\circ} \mathrm{C}$ & $12.4^{\circ} \mathrm{C}$ & $-0.1^{\circ} \mathrm{C}$ & $458 \mathrm{~mm}$ \\
\hline Cooper Landing & $60^{\circ} 29^{\prime} \mathrm{N}$ & $149^{\circ} 58^{\prime} \mathrm{W}$ & $116 \mathrm{~m}$ & $1975-1987$ & $-6.3^{\circ} \mathrm{C}$ & $13.5^{\circ} \mathrm{C}$ & $2.2^{\circ} \mathrm{C}$ & $669 \mathrm{~mm}$ \\
\hline Seward & $60^{\circ} 07^{\prime} \mathrm{N}$ & $149^{\circ} 27^{\prime} \mathrm{W}$ & $11 \mathrm{~m}$ & $\begin{array}{l}1922-1925 \\
1930-1987\end{array}$ & $-3.9^{\circ} \mathrm{C}$ & $13.2^{\circ} \mathrm{C}$ & $4.2^{\circ} \mathrm{C}$ & $1,720 \mathrm{~mm}$ \\
\hline Portage & $60^{\circ} 49^{\prime} \mathrm{N}$ & $148^{\circ} 58^{\prime} \mathrm{W}$. & $12 \mathrm{~m}$ & 1983-1987 & $0.2^{\circ} \mathrm{C}$ & $12.8^{\circ} \mathrm{C}$ & $2.9^{\circ} \mathrm{C}$ & $1,963 \mathrm{~mm}$ \\
\hline
\end{tabular}

\section{Present-Day Climate}

The southern and eastern coasts of the Kenai Peninsula have a maritime climate characterized by heavy precipitation, much of it falling as snow at higher altitudes. The Kenai Mountains act as an effective moisture barrier, creating a partial precipitation shadow in the Kenai Lowlands, particularly in the northern lowlands. Climate data from stations to the northeast (Portage), southeast (Seward), and two areas west of Tern Lake (Cooper Landing and Sterling, fig. 1; table 1) show the differences in temperature and precipitation from the coast into the precipitation shadow of the Kenai Mountains.

\section{Vegetation in the Northern Kenai Mountains}

Present-day distribution of major vegetation types of the Kenai Mountains is shown in Viereck and Little's vegetation map of Alaska (1972), and the Joint Federal-State Land Use Planning Commission for Alaska's "Major Ecosystems of Alaska" map (1973). Both maps indicate that coastal forest vegetation covers the major valleys in the Kenai Mountains. In reality, however, only the outer coastal areas of the Kenai Mountains, and the valley segments immediately adjacent to the Gulf of Alaska, are vegetated entirely by true Pacific coastal forest floras. Within the Kenai Mountains, the vegetation in the major valleys is a diverse mixture of Pacific coastal forest and boreal forest floras, varying in composition from area to area. In the western valleys of the mountains, a major influence of boreal species (e.g., Picea glauca: white spruce; $P$. mariana : black spruce; Betula papyrifera : paper birch; Populus balsamifera : balsam poplar; P. tremuloides : quaking aspen) is evident, while in the valleys near the northern and southern coasts (e.g., near Turnagain Arm and Seward), species adapted to the maritime climates of the coast are much more dominant (e.g., Tsuga mertensiana : mountain hemlock; Picea sitchensis : Sitka spruce; Populus trichocarpa : black cottonwood). According to Viereck and Little (1975) and field observations (Ager, unpub. field notes) coastal forest predominates from Seward northward to the Kenai Lake area (fig. 2) where boreal forest taxa become conspicuous. Boreal taxa become increasingly abundant west of the Tern Lake area. Northeast of Tern Lake, coastal forest vegetation predominates in the Quartz Creek-Canyon Creek valley from just south of Summit Lake (fig. 2) to the coast of upper Turnagain Arm. The present-day distribution of major vegetation types on the Kenai Peninsula (fig. 3) shows extensive areas with mixed coastal and boreal forest vegetation over much of the central, lowland areas of the peninsula. To illustrate the extent of mixing of these floras, table 2 lists the tree and shrub species that occur today in the Tern Lake area. The table indicates whether a given species is primarily an interior (boreal forest) plant, or an element of the Pacific coastal flora based on its modern distribution. A list of herbaceous plant species would also show a significant mixture of interior and coastal plants in this area (Hultén, 1968).

Forests occupy most valley floors but are interspersed with some areas of meadows and bogs. Forests also occupy the lower slopes of the valleys. The upper boundary of forest vegetation in these montane valleys varies substantially in altitude over short horizontal distances $(<1 \mathrm{~km})$. This irregular boundary between forests and alder thickets is controlled in part by slope angle and snow avalanche frequency. Figure 4 shows vegetation near Tern Lake, with a largely forested valley floor and the mixture of forest and alder (Alnus) shrub thickets covering the adjacent lower slopes of the valley walls. The photograph was taken from the northern shore of Tern Lake looking toward the south. In the foreground emergent aquatic and semi-aquatic vegetation (Menyanthes: buckbean; Carex : sedge) can be seen growing in shallows near the lakeshore.

Altitudinal limits of trees vary substantially in the Kenai Mountains, from about $400 \mathrm{~m}$ on the outer coast to about $700 \mathrm{~m}$ or higher inland. Immediately above the upper edge of forests, dense alder thickets cover the valley walls up to about $900 \mathrm{~m}$. Alpine-shrub and herb-tundra communities occur at higher elevations, interspersed with talus slopes, steep bedrock slopes, snow patches, and icefields. 


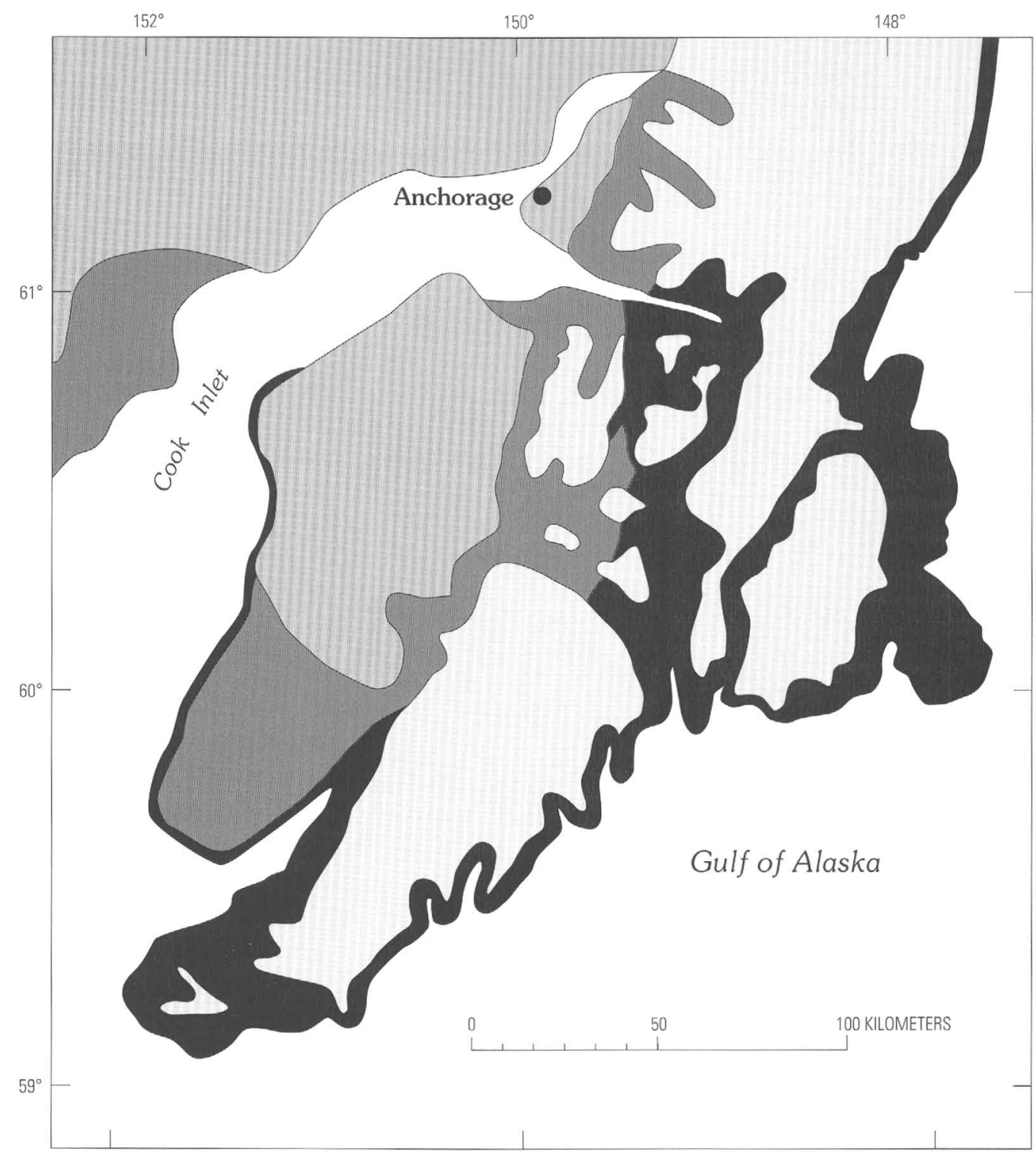

EXPLANATION

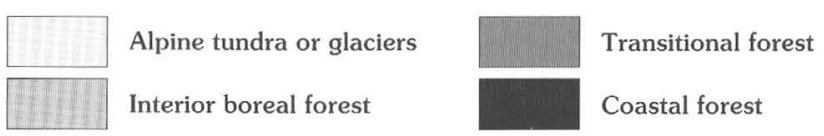

Figure 3. Map of present-day vegetation of Kenai Peninsula, showing areas of boreal forest, transitional boreal/coastal forest, coastal forest, and alpine tundra and glaciers. The figure is modified from Joint Federal-State Land Use Planning Commission for Alaska (1973) and Viereck and Little's Vegetation Map of Alaska (1972). Modifications are based on tree and shrub range maps in Viereck and Little (1975) and field observations of the author.

\section{Methods}

The 103-cm-thick peat section was sampled in 5-cmthick blocks, except the basal sample, which was $3 \mathrm{~cm}$ thick. The peat blocks were later sub-sampled for pollen analysis and radiocarbon dating. The peat samples were washed through sieves to remove coarse plant detritus (moss and sedge remains, roots, twigs). The fine fraction was then processed using standard palynological procedures for Quaternary peat samples to concentrate pollen and spores for microscopic examination. Whenever possible, at least 300 pollen grains were counted for each sample, and percentages of each pollen type were calculated from a sum of all pollen grains counted per sample. In all samples from this site, spores of ferns 
Table 2. Major trees and shrubs found in the Tern Lake area, Kenai Mountains, southcentral Alaska.

[From Viereck and Little $(1972,1975)$. Common names are given in column 2. (T), tree; (S), shrub; (LW), low-growing woody plant. For each species, its common habitat is shown as either coastal (column 3) or interior (column 4). Some plant species are cosmopolitan, able to grow in both interior or coastal environments. For a few species, the predominant occurrences are in the interior, but these plants may occasionally found in some coastal environments (X). Species marked with asterisks $\left(^{*}\right)$ in column 1 represent interior (boreal) plants that are growing at or near their easternmost range limits near Tern Lake]

\begin{tabular}{|c|c|c|c|}
\hline Taxon & Common name & $\begin{array}{c}\text { South } \\
\text { coast } \\
\text { habitat }\end{array}$ & Interior \\
\hline Picea mariana* & Black spruce $(\mathrm{T})$ & & $\mathrm{X}$ \\
\hline Picea glauca* & White spruce $(\mathrm{T})$ & & $X$ \\
\hline Picea sitchensis & Sitka spruce $(\mathrm{T})$ & $\mathrm{X}$ & \\
\hline Tsuga mertensiana & Mountain hemlock $(\mathrm{T})$ & $\mathrm{X}$ & \\
\hline Juniperus communis* & Common juniper $(\mathrm{S})$ & $(\mathrm{X})$ & $\mathrm{X}$ \\
\hline Populus balsamifera* & Balsam poplar (T) & & $\mathrm{X}$ \\
\hline Populus trichocarpa & Black cottonwood $(\mathrm{T})$ & $\mathrm{X}$ & \\
\hline Populus tremuloides* & Quaking aspen (T) & & $\mathrm{X}$ \\
\hline Salix alaxensis & Feltleaf willow (S) & $\mathrm{X}$ & $\mathrm{X}$ \\
\hline Salix arbusculoides* & Littletree willow (S) & & $\mathrm{X}$ \\
\hline Salix barclayi & Barclay willow (S) & $\mathrm{X}$ & $X$ \\
\hline Salix bebbiana* & Bebb willow (S) & $(\mathrm{X})$ & $\mathrm{X}$ \\
\hline \multicolumn{4}{|l|}{ Salix planifolia } \\
\hline subsp pulchra* & Diamondleaf willow (S) & $(\mathrm{X})$ & $\mathrm{X}$ \\
\hline Salix scouleriana & Scouler willow $(\mathrm{S})$ & $\mathrm{X}$ & $\mathrm{X}$ \\
\hline Salix sitchensis & Sitka willow (S) & $X$ & \\
\hline Myrica gale & Sweetgale (S) & $\mathrm{X}$ & $\mathrm{X}$ \\
\hline Betula nana* & Dwarf arctic birch (S) & & $\mathrm{X}$ \\
\hline Betula glandulosa* & Resin birch (S) & & $\mathrm{X}$ \\
\hline Betula papyrifera* & Paper birch (T) & & $X$ \\
\hline Alnus crispa & American green alder (S) & & $\mathrm{X}$ \\
\hline Alnus sinuata & Sitka alder (S) & $\mathrm{X}$ & $(\mathrm{X})$ \\
\hline Alnus tenuifolia* & Thinleaf alder (S) & & $\mathrm{X}$ \\
\hline Ribes hudsonianum* & Northern black currant (S) & & $\mathrm{X}$ \\
\hline Ribes lacustre & Swamp gooseberry (S) & $\mathrm{X}$ & $\mathrm{X}$ \\
\hline Ribes laxiflorum & Trailing black currant (S) & $\mathrm{X}$ & \\
\hline Ribes triste* & American red currant (S) & & $\mathrm{X}$ \\
\hline Amelanchier alnifolia & Western serviceberry (S) & $(\mathrm{X})$ & $\mathrm{X}$ \\
\hline Potentilla fruticosa* & Bush cinquefoil (S) & & $\mathrm{X}$ \\
\hline Rosa acicularis* & Prickly rose (S) & & $\mathrm{X}$ \\
\hline Rubus idaeus* & American red raspberry $(\mathrm{S})$ & $(\mathrm{X})$ & $\mathrm{X}$ \\
\hline Rubus spectabilis & Salmonberry (S) & $\mathrm{X}$ & \\
\hline Sorbus scopulina* & Green mountain ash (S) & $(\mathrm{X})$ & $\mathrm{X}$ \\
\hline Sorbus sitchensis & Sitka mountain ash (S) & $\mathrm{X}$ & \\
\hline Spiraea beauverdiana & Beauverd spiraea $(S)$ & $(\mathrm{X})$ & $\mathrm{X}$ \\
\hline Shepherdia canadensis* & Soapberry (S) & & $\mathrm{X}$ \\
\hline Oplopanax horridus & Devil's club & $\mathrm{X}$ & \\
\hline Empetrum nigrum & Crowberry (LW) & $\mathrm{X}$ & $\mathrm{X}$ \\
\hline Arctostaphylos uva-ursi & Bearberry (LW) & $(\mathrm{X})$ & $X$ \\
\hline Ledum decumbens* & Narrowleaf Labrador tea (LW) & & $\mathrm{X}$ \\
\hline
\end{tabular}


Table 2. Major trees and shrubs found in the Tern Lake area, Kenai Mountains, southcentral Alaska-Continued.

\begin{tabular}{llll}
\hline \multicolumn{1}{c}{ Taxon } & \multicolumn{1}{c}{ Common name } & $\begin{array}{c}\text { South } \\
\text { coast } \\
\text { habitat }\end{array}$ & Interior \\
\hline Ledum groenlandicum & Labrador tea (LW) & $\mathrm{X}$ & \\
Menziesia ferruginea & Rusty menziesia (S) & $\mathrm{X}$ & \\
Vaccinium caespitosum & Dwarf blueberry (LW) & $\mathrm{X}$ & \\
Vaccinium ovalifolium & Early blueberry (S) & $\mathrm{X}$ & \\
Vaccinium vitis-idaea & Bog blueberry (LW) & $\mathrm{X}$ & $\mathrm{X}$ \\
Sambucus callicarpa & Pacific red elder (S) & $\mathrm{X}$ & \\
Viburnum edule & Highbush cranberry (S) & $\mathrm{X}$ & $\mathrm{X}$ \\
\hline
\end{tabular}

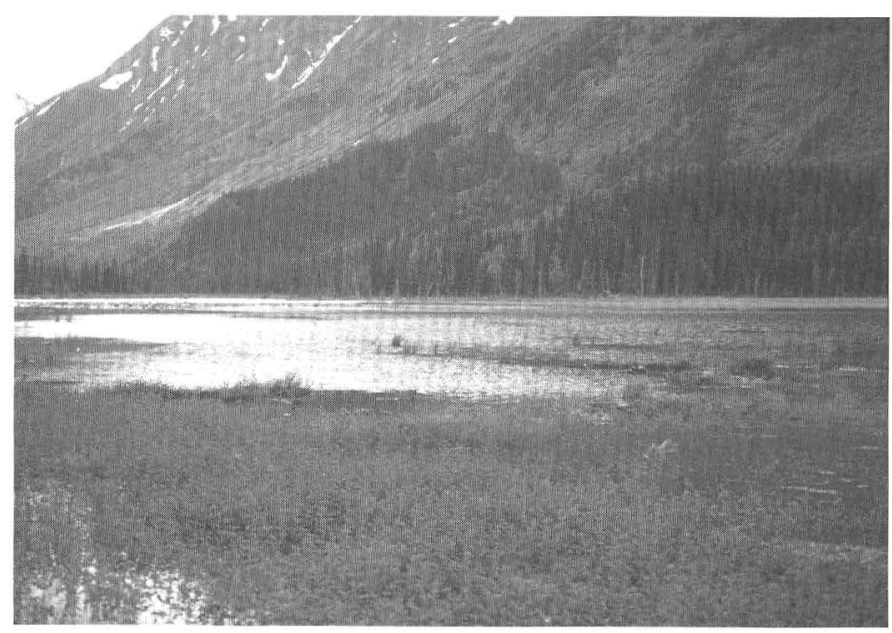

Figure 4. Vegetation and terrain in the Tern Lake area, central Kenai Mountains, Kenai Peninsula. Valley bottom vegetation is a mixture of coastal and interior (boreal) forest trees, shrubs, and herbs. Frequent snow avalanches limit growth of conifer forests on steep valley slopes. Avalanche scars and steep slopes are vegetated mostly by alder thickets up to about $900 \mathrm{~m}$. This photograph was taken from the north shore of Tern Lake looking toward the south-southwest.

were abundant, and other spore-producing plants were also commonly represented. By convention, spore percentages were calculated from a sum composed of both total pollen and spores counted in each sample.

Identification of pollen types was accomplished by reference to a collection of modern pollen and spore reference slides housed at the U.S. Geological Survey. Quality of preservation of conifer pollen was poor in some samples from the upper half of the section. The preservation conditions resulted in fragmentation of many conifer pollen grains. This made accurate counts difficult and introduced some error into the counts of spruce and mountain hemlock grains. It is unlikely that this significantly altered the results or interpretations of the Tern Lake peat section.

Two bulk peat samples from the Tern Lake peat section were radiocarbon-dated by conventional methods at the U.S. Geological Survey radiocarbon laboratory in Reston, Va., during the mid-1980's. Three additional small samples of peat were dated in 1999 by means of atomic mass spectrometer (AMS) radiocarbon-dating methods, which requires much smaller sample weights to produce an age determination than was required for conventional radiocarbon dating. Radiocarbon ages of all the samples from the Tern Lake peat section are shown in table 3 . The three recently dated samples were prepared for analysis by Jack McGeehin of the U.S. Geological Survey, and the samples were analyzed at the Lawrence Livermore AMS radiocarbon dating laboratory in California. Using the five radiocarbon dates, approximate ages for the boundaries between pollen zones were interpolated (or extrapolated in the case of the base of the section).

The samples used for this investigation were collected from a fresh roadcut along the southwest side of the Seward Highway, $0.8 \mathrm{~km}$ northwest of Tern Lake in the central Kenai Mountains (fig. 1, fig. 2). The site is at an altitude of about $260 \mathrm{~m}$, within the Seward (C-7) quadrangle, at lat $60^{\circ} 32^{\prime} \mathrm{N}$., long $149^{\circ} 33.5^{\prime} \mathrm{W}$. The valley in which the peat accumulated during the Holocene was filled with glacial ice during the late Wisconsin glaciation (Karlstrom, 1964, plate 1; this paper, fig. 2). The section consists of about $103 \mathrm{~cm}$ of fibrous peat,

Table 3. Radiocarbon dates on fibrous peat samples from the Tern Lake peat section.

[Conventional (bulk) radiocarbon dates are signified by a laboratory number preceded by a "W." AMS radiocarbon dates are signified with a "WW" laboratory prefix]

\begin{tabular}{ccc}
\hline Sample depth & Radiocarbon age & Lab number \\
\hline $32.5 \mathrm{~cm}$ & $2515 \pm 60$ yr B.P. & WW-2237 \\
$57.5 \mathrm{~cm}$ & $4525 \pm 65$ yr B.P. & WW-2238 \\
$60-65 \mathrm{~cm}$ & $5350 \pm 200 \mathrm{yr}$ B.P. & W-5576 \\
$87.5 \mathrm{~cm}$ & $8340 \pm 120 \mathrm{yr}$ B.P. & WW-2339 \\
$95-100 \mathrm{~cm}$ & $9310 \pm 200 \mathrm{yr}$ B.P. & W-5539 \\
\hline
\end{tabular}


overlying about $4 \mathrm{~m}$ of glacial till containing cobble-sized clasts in a finer matrix.

\section{Results of Analyses}

Results of the analyses of the 21 pollen samples are presented in a pollen and spore percentage diagram (figs. $5 \mathrm{~A}$, $5 B$ ). The pollen diagram is divided into four pollen assemblage zones $\mathrm{T}-1$ through $\mathrm{T}-4$, from top to the base of the section. The basal zone, T-4, from 89- to $103-\mathrm{cm}$ depth in the section (ca. 8,600-9,800 yr B.P.), is characterized by pollen of several shrub types: Betula, Alnus, Salix, Shepherdia canadensis (soapberry), Viburnum (highbush cranberry), and Ericales (Ericaceae : heath family, and Empetrum : crowberry). Also represented by small amounts of pollen are two genera of the Rosaceae (rose family): Potentilla (cinquefoil) and Sanguisorba (burnet) (see table 2 for an explanation of woody plant taxonomic terms used in this paper). Herbaceous plants represented include Poaceae (grass family), Cyperaceae (sedge family), Artemisia (wormwood), Asteraceae Subf. Asteroideae (Aster family, Aster subfamily), Epilobium (fireweed), Caryophyllaceae (pink family), Polemonium (Jacob's Ladder), Heracleum (cow parsnip), and other Apiaceae (carrot family) (see table 4 for taxonomic terms used for all non-woody plants discussed in this paper).

Fern spores of Polypodiaceae (licorice fern family) type are abundant, but there are also small amounts of the fern spore type Cryptogramma (parsley fern). A few other sporeproducing plants are represented: Lycopodium annotinum (stiff club moss), Equisetum (horsetail or scouring rush), and Huperzia selago (fir club moss). A radiocarbon date from within this zone is shown in table 3 .

Pollen assemblage zone T-3 is divided into two subzones, T-3a and T-3b. Subzone T-3b (83- to 89-cm depth, ca.

$7,800-8,600 \mathrm{yr}$ B.P.) consists of a single sample, but its unique characteristics justify separating the assemblage into its own subzone. The sample is composed primarily of Shepherdia canadensis pollen, but pollen of Alnus, Betula, and Cyperaceae are also present, and spores of Polypodiaceae ferns are abundant ( $>55$ percent), but slightly less so than in zone T-4. Other spore-producing plants present include Lycopodium annotinum and Equisetum.

Subzone T-3a (65- to 83-cm depth; ca. 5,650-7,800 yr B.P.) is characterized by abundant pollen of Alnus ( $>67$ percent), and declining percentages of Shepherdia canadensis pollen. The latter is present in smaller percentages $(<15$ percent) than in Subzone T-3b and is reduced to a few percent at the top of Subzone T-3b. Also present are small amounts of Picea, Betula, Salix, Cyperaceae, and Apiaceae pollen. A few other herbaceous taxa are also present, but in very small percentages, and they do not occur in all samples. Polypodiaceae fern spores are abundant within the subzone, along with smaller percentages of Lycopodium annotinum and $L$. clavatum (common club moss).
Assemblage zone T-2 (37- to 65-cm depth; ca. $2,880-5,650$ yr B.P.) is also characterized by high percentages of Alnus pollen, comprising about 60-70 percent of the pollen sum. In contrast to the underlying zone, Shepherdia canadensis is absent. Betula and Picea pollen are well represented, along with trace amounts of Tsuga mertensiana pollen. Pollen of Oplopanax (devil's club) appears in this zone for the first time within this zone. Also present are small amounts of Poaceae, Cyperaceae, Polemonium, Apiaceae, Campanula (Harebell), and Valeriana (valerian) pollen. Polypodiaceae-type fern spores are abundant within this zone (35-65 percent), although less so than in zone T-3. Lycopodium annotinum is a common element found in every sample in this zone. Small amounts of Sphagnum moss spores also occur.

The upper pollen assemblage zone T-1 $(0-37 \mathrm{~cm}$; 0 to ca. $2,880 \mathrm{yr}$ B.P.) is characterized by the highest percentages of Picea pollen (ranging from ca. 25 to 55 percent) in the section. Alnus percentages are lower in this zone than in zone T-2 but are still present in significant amounts (generally $>30$ percent of the pollen sum). Betula pollen is present in amounts of about 10-20 percent. Tsuga mertensiana pollen is more abundant than in any other zone within the section. Also present in some samples within this zone are small percentages of Salix, Ericales, Oplopanax, Poaceae, Cyperaceae, Artemisia, Polemonium, Heracleum, and Valeriana pollen. Polypodiaceae fern spores are abundant within this zone, but in a sample from 12-cm depth in the section, the percentages of fern spores reach their lowest level $(<30$ percent of the pollen + spore sum) within the entire peat section. Lycopodium annotinum is present in all samples within this zone, and small amounts of Sphagnum moss spores occur in several samples within zone $\mathrm{T}-1$.

\section{Interpretation of Vegetation History}

The pollen record from the Tern Lake peat section provides data to construct the first radiocarbon-dated vegetation history for the Kenai Mountains. The record spans the past ca. 9,800 radiocarbon years, when peat began accumulating over glacial till after the local glacial ice melted away. The site may have been free of glacier ice several centuries or more before 9,800 yr B.P.

Pollen zone T-4, at the base of the section (figs. $5 A, 5 B$ ), represents the earliest recorded colonizing vegetation in the area beginning about $9,800 \mathrm{yr}$ B.P. The pollen assemblage suggests that the local vegetation was a treeless shrub-herb "tundra" that included shrub Betula, small amounts of Alnus, Salix, Ericales, Shepherdia canadensis, Viburnum, and Sorbus.

Figures $\mathbf{5 A}$ and $\mathbf{5 B}$ (following pages). Pollen percentage diagram from the Tern Lake Peat Section, central Kenai Mountains, Alaska. For a list of common names for plant taxa, refer to table 2 (woody plants) and table 4 (non-woody plants). 


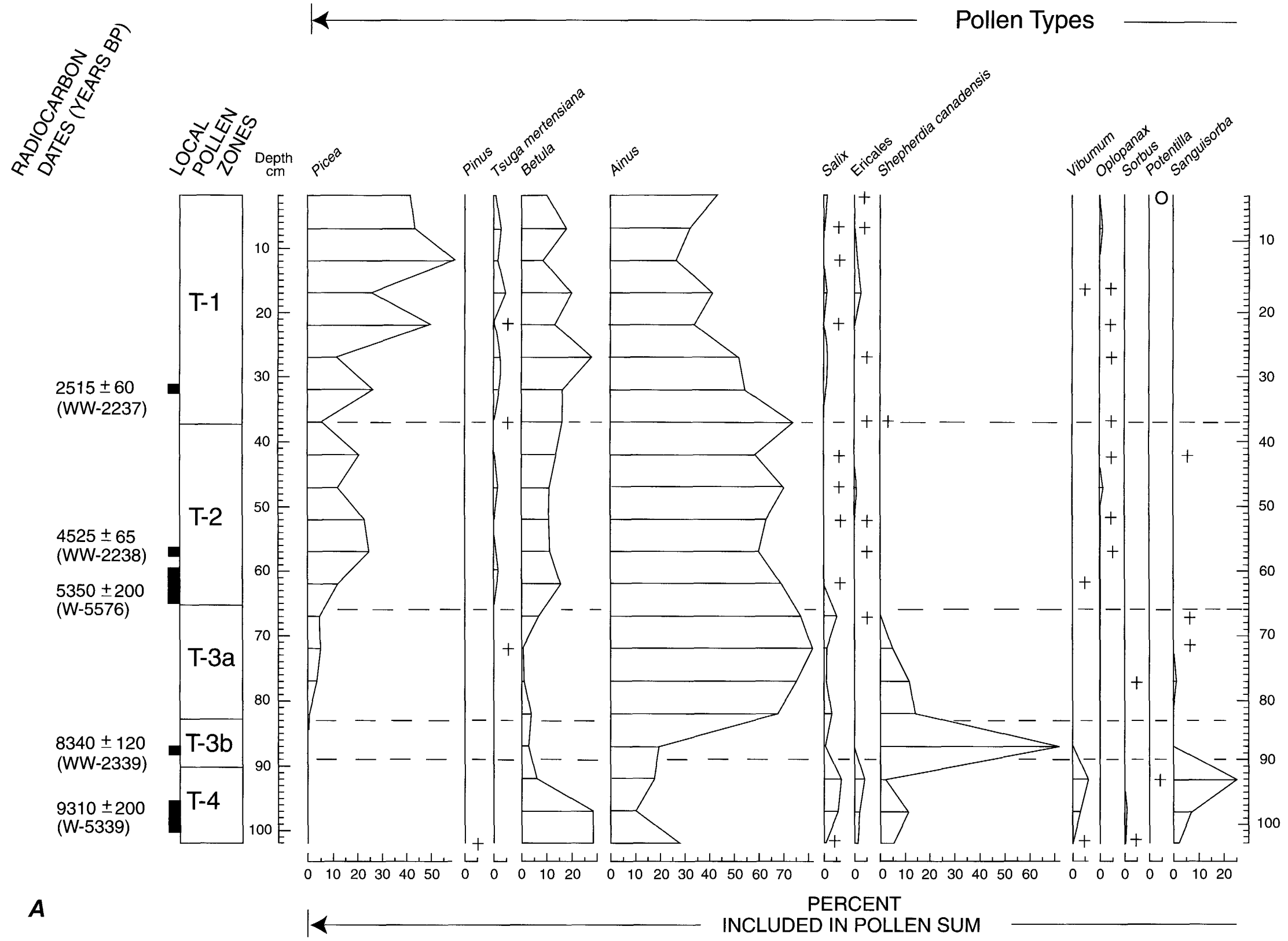

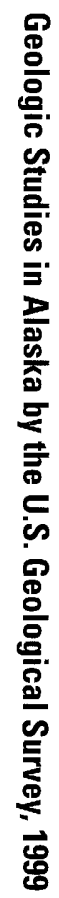




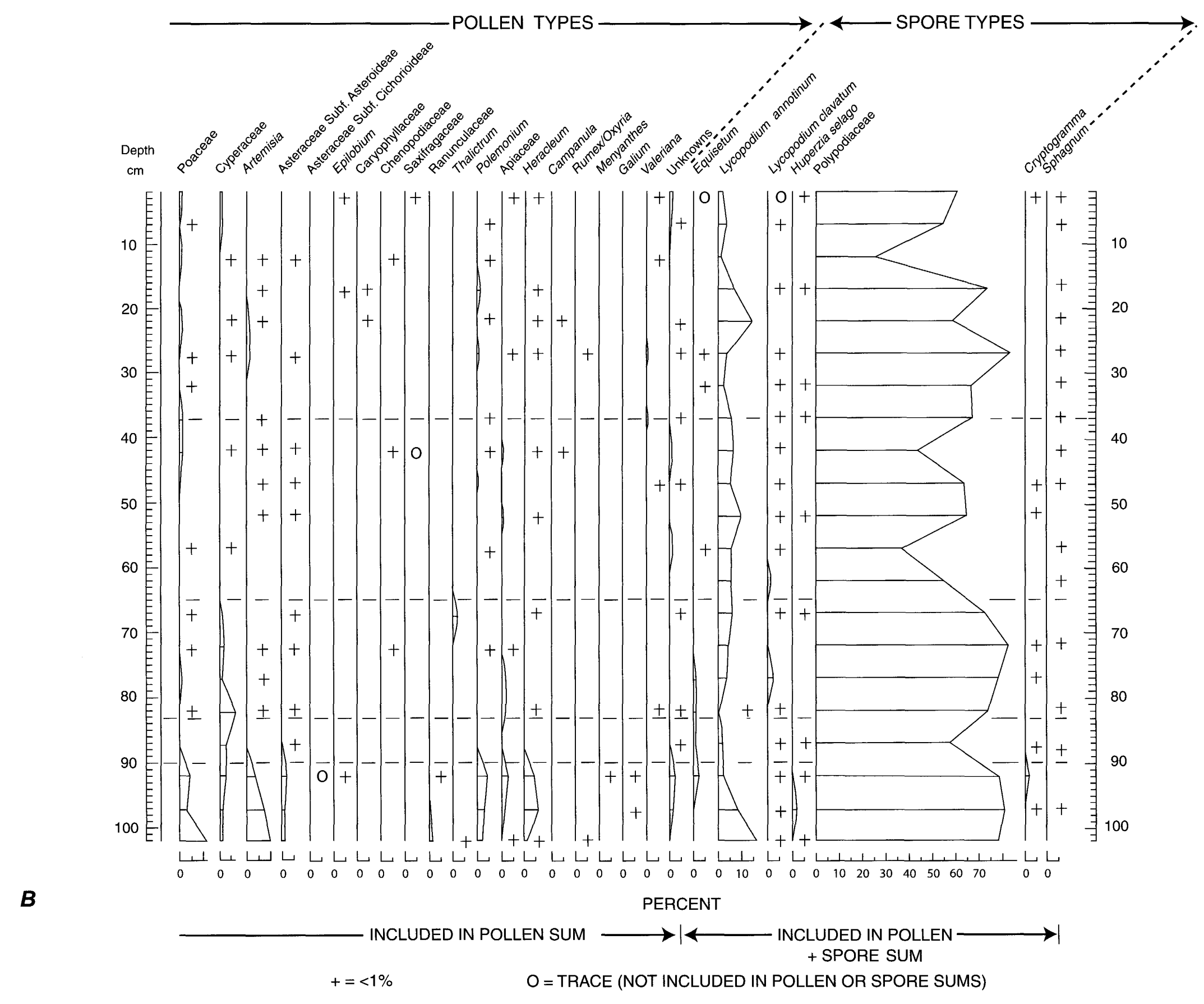


Table 4. Taxonomy of non-woody vascular plants mentioned in this paper.

[Sphagnum has been included in this list, but it is a moss-a non-vascular plant. Where taxonomic terms have been updated from Hultén (1968), the superseded term is shown in parentheses]

\begin{tabular}{|c|c|c|}
\hline Taxon & Alternate name & Common name \\
\hline Poaceae & (Gramineae) & Grass family \\
\hline Cyperaceae & & Sedge family \\
\hline Artemisia & & Wormwood, sage \\
\hline Asteraceae & (Compositae) & Aster or Composite family \\
\hline subf. Asteroideae & (Tubuliflorae) & Aster subfamily \\
\hline subf. Cichorioideae & (Liguliflorae) & Chicory subfamily \\
\hline Epilobium & & Fireweed \\
\hline Caryophyllaceae & & Pink family \\
\hline Chenopodiaceae & & Goosefoot family \\
\hline Saxifragaceae & & Saxifrage family \\
\hline Ranunculaceae & & Crowfoot family \\
\hline Thalictrum & & Meadow-rue \\
\hline Polemonium & & Jacob's ladder \\
\hline Apiaceae & (Umbelliferae) & Carrot family \\
\hline Heracleum & & Cow parsnip \\
\hline Campanula & & Bluebells, harebell \\
\hline Rumex & & Dock, sorrel \\
\hline Oxyria & & Mountain sorrel \\
\hline Menyanthes & & Buckbean \\
\hline Galium & & Bedstraw \\
\hline Valeriana & & Valerian \\
\hline Lycopodium annotinum & & Stiff club moss \\
\hline Lycopodium clavatum & & Common club moss \\
\hline Huperzia selago & (Lycopodium selago) & Fir club moss \\
\hline Polypodiaceae & & Licorice fern family \\
\hline Cryptogramma & & Parsley fern \\
\hline Sphagnum & & Sphagnum moss \\
\hline
\end{tabular}

Other low woody plants present include Sanguisorba and Potentilla. Herbs include Poaceae, Cyperaceae, Artemisia, Asteraceae subf. Asteroideae, Epilobium, Heracleum, and Caryophyllaceae. Ferns of the Cryptogramma and Polypodiaceae types are present. The abundance of Polypodiaceae-type spores suggests that these ferns were common elements of the vegetation. Today ferns often form a dense understory growth beneath a protective canopy of Alnus shrubs in southern coastal Alaska.

The plant assemblage represented in this pollen zone suggests that the local vegetation included herb meadows, interspersed with patches of shrubs in the area. The plant assemblage also indicates that there were moist local habitats available in order to support the growth of abundant ferns as well as herbs such as Heracleum and other Apiaceae, Ericales and Salix shrubs, and tall Sorbus shrubs.

The presence of Shepherdia canadensis, Artemisia, Poaceae, Potentilla, Epilobium, and Caryophyllaceae suggests that expanses of barren gravel outwash plain may have been growing nearby during deposition of Zone T-4 peat. These plants, along with Alnus and Salix, were likely colonizers of such barren flood-plain environments. Spore-producing plants such as Equisetum and Lycopodium are also hardy plants often found as early colonizers of disturbed ground and freshly exposed glacial till and gravel deposits.

Subzone T-3b consists of only a single sample, which has a very unusual pollen and spore assemblage. It is composed primarily of Shepherdia canadensis pollen, whereas nearly all other taxa are either absent or reduced to minute percentages, except Alnus (ca. 20 percent) and fern spores (55 percent of the combined pollen + spore sum). The plant assemblage suggests that a nearby disturbance, such as a flood or a possible resurgence of outwash gravel deposition, may have destroyed much of the flood-plain vegetation along Quartz Creek (fig. 2). The resulting outwash plains of barren sand and gravel were then recolonized primarily by Shepherdia and Alnus shrubs. 
The radiocarbon date of $8,340 \pm 120 \mathrm{yr}$ B.P. associated with this single sample subzone is not clearly linked to any welldocumented early Holocene alpine glaciation in the region. However, there is some evidence of a possible early Holocene glacial event in the upper Cook Inlet region at about that time (Schmoll and others, 1999). Additional research in the Kenai Mountains will be required to determine if this represents just a local disturbance of vegetation, or part of a more regionalscale response of vegetation to climate change associated with a glacial event associated with outwash deposition downvalley from the ice.

Subzone T-3a represents a major colonization of the interior Kenai Mountain valleys by alder thickets soon after 7,800 radiocarbon yr B.P. Decreases in Shepherdia, Betula, Salix, and most herb genera implied by the pollen data suggest that thickets of Alnus may have covered much of the valley landscape, leaving limited areas for other taxa to grow. Picea pollen (ca. 5 percent of the pollen sum) began to arrive at the site during this phase of the vegetation history. The small amounts of Picea pollen present in the subzone suggest that spruce trees had probably not arrived locally. Pollen records from upper Turnagain Arm and Prince William Sound show that no other Picea populations existed in those areas until the late Holocene, when Picea sitchensis began to colonize from the east (Ager, unpub. data; Heusser, 1960, 1983, 1985). Therefore, the Picea pollen arriving near Tern Lake soon after about 7,800 yr B.P. did not come from spruce populations colonizing the Kenai Mountains from the north (upper Turnagain Arm) or east (Prince William Sound).

The appearance of Picea pollen in the Tern Lake area is consistent with previously collected evidence from the northern Kenai Lowland. Pollen data from Hidden Lake (fig. 1, site 4; fig. 2; Ager, 1983) and from Longmere Lake in the northern Kenai Lowlands (fig. 1, site 3; Ager, unpub. data) indicate that boreal spruce had arrived in those areas by about 7,800 yr B.P. This colonization of the northern Kenai Lowlands occurred only about 2 centuries after boreal spruce trees began to colonize the lowlands where the city of Anchorage is now located, north of upper Turnagain Arm (fig. 1; Ager and Brubaker, 1985). During the early Holocene, boreal spruce trees spread very rapidly through valleys and lowlands of eastern interior and south-central Alaska and upper Cook Inlet (Ager, 1983, 1989, 2000; Ager and Brubaker, 1985).

Zone T-2 records the local invasion of boreal forest trees (e.g., Picea glauca, P. mariana, Betula papyrifera) during middle Holocene time. Whereas the Betula pollen in the lower part of the section (below $70 \mathrm{~cm}$ ) was probably derived from shrub birch, most of the Betula pollen in the upper $70 \mathrm{~cm}$ of the section is probably from tree birch, which produces large amounts of wind-borne pollen. Alnus pollen percentages decline in this zone, suggesting that alder thickets were being replaced in part by forest vegetation on the valley floor and the lower slopes of the local valleys. Traces of Tsuga mertensiana pollen occur within this zone, suggesting that there may have been some outlier populations of mountain hemlock trees developing in the western Prince William Sound area, and pos- sibly along the eastern flanks of the Kenai Mountains, during middle Holocene time. Heusser's pollen diagrams from various sites in Prince William Sound show great variation in the local vegetation histories from island to island and from fiord to fiord along the mainland coast. This suggests that windborne seeds spread westward sporadically (Heusser, 1960, 1983, 1985). These random seed-dispersal events established local tree populations wherever the seeds landed in suitable habitats. In addition to mountain hemlock, another coastal plant species that arrived near Tern Lake during middle Holocene time was Oplopanax. Intermixing of coastal and boreal floras was therefore well underway by mid-Holocene time in the north-central Kenai Mountains.

Pollen zone T-1 represents about the past 2,900 radiocarbon years (late Holocene), during which Alnus thickets continued to be replaced by locally expanding spruce-birch forests and the growing influence of coastal forest species in the area. The increases in spruce pollen percentages, especially in the upper ca. $25 \mathrm{~cm}$ of the section, along with increasing but low percentages of mountain hemlock pollen, suggest that Sitka spruce and mountain hemlock trees were invading the valleys of the central Kenai Mountains by about 2,000 radiocarbon years ago. The pollen of Picea glauca and Picea sitchensis cannot be differentiated, so the local arrival of the latter species can only be inferred from the available evidence. However, the timing of the increase in percentages of Picea pollen in the Tern Lake area is consistent with recent findings of pollen evidence for the invasion of the Girdwood area in upper Turnagain Arm (fig. 2) by Sitka spruce and mountain hemlock trees by about 2,200 yr B.P. (Ager, unpub. data). Picea glauca and $P$. sitchensis are closely related species that readily hybridize when their populations come into close proximity. The resulting hybrids look much like Picea glauca, but often have larger cones and longer needles than typically occur on $P$. glauca trees. These hybrid spruce may have environmental tolerances that differ somewhat from those of the contributing pure species (Viereck and Little, 1972; Ager, 2000). It is possible that the increase in Picea pollen percentages during the late Holocene in the Tern Lake area reflects the arrival of hybrid spruce rather than Picea sitchensis.

The colonization of Prince William sound and eastern and southern Kenai Peninsula by coastal forest vegetation during late Holocene time coincides with a significant increase in precipitation along the southern coast of Alaska (Heusser and others, 1985; fig. 6). The wetter climate was probably highly favorable for establishing populations of coastal tree species.

Distribution maps of boreal trees and shrubs on the Kenai Peninsula (Viereck and Little, 1975) show that many of these plant species attain their easternmost limits within the Kenai Mountains at or near Tern Lake. These range limits cannot be explained by topographic barriers that would prevent these taxa from spreading to upper Turnagain Arm or to the southern coast (e.g., to the Seward area) via the valley system within the Kenai Mountains. Some boreal species such as Picea mariana did spread nearly as far as Seward (Viereck and Little, 1975), but most boreal species did not develop populations along the 


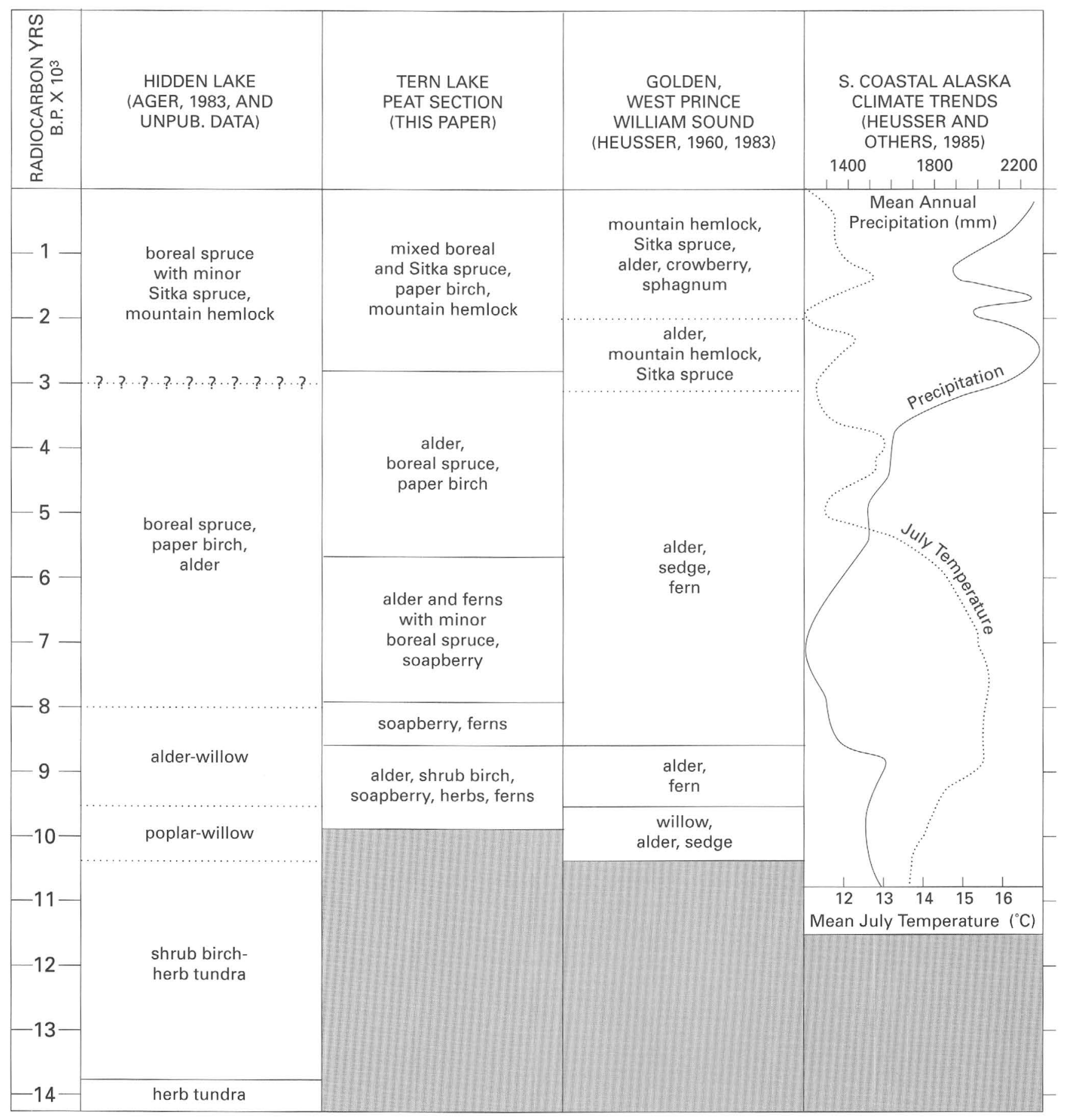

Figure 6. Chart comparing postglacial vegetation histories from three sites located in different climatic regimes across the northern Kenai Peninsula and northwest Prince William Sound: (1) Hidden Lake, in the partial precipitation shadow of the Kenai Mountains (fig. 1, site 4); (2) Tern Lake peat section, north-central Kenai Mountains, near the boundary between transitional and maritime climate types (fig. 1, site 5); and (3) Golden, a peat section from a coastal site with maritime climate (fig. 1, site 7). Holocene climate trends for the southern coast of Alaska (modified from Heusser and others, 1985) show the coincidence between relatively warm, dry climate and the spread of boreal-forest plants during the early Holocene and cool, wet climate and the development of coastal forest vegetation along the coast of Prince William Sound and the eastern Kenai Peninsula during the late Holocene. 
southern or eastern coasts of the Kenai Peninsula or along upper Turnagain Arm. The fact that many boreal taxa reach their eastern range limits near Tern Lake suggest that climate limits their further spread to Turnagain Arm and the Gulf of Alaska coast. Wetter winters and cool, wet summers near the coast may have excluded them from further expansion eastward, northeastward and southward. It is possible that some coastward expansion of these boreal plant populations occur during drier climatic intervals, followed by contraction of the leading edge of those populations during wetter times, but at present there are no data to test that idea.

An interesting example of a boreal species reaching the apparent limits of its climatic tolerance is Shepherdia canadensis. The pollen record from the Tern Lake peat section indicates that it was present near Tern Lake by ca. 9,800 yr B.P., that it flourished locally for about 3,500 years during the early Holocene, then declined to become a very minor component of the local vegetation. A present-day distribution map for Shepherdia canadensis in Alaska (Viereck and Little, 1975) suggests that the species has apparently not expanded its range in the Kenai Mountains since the early Holocene, or if it has, its range has contracted to about where it was during the early Holocene. Its relative rarity in the area today may reflect the reduction in areal extent of nearly barren outwash gravels in the valley bottoms, a habitat where it is often found (Hultén, 1968). Heusser's pollen records from Kenai Peninsula (Heusser, 1960) show no occurrences of Shepherdia canadensis pollen near Seward or in the valleys northeast of Tern Lake. His pollen records from near Girdwood and from Prince William Sound show no trace of this pollen type (Heusser, $1960,1983)$. Shepherdia canadensis appears to be adapted to interior, continental climates. The eastern edge of its known range on the Kenai Peninsula is near Tern Lake today and extends southward about $20 \mathrm{~km}$ south of Tern Lake toward Seward (Viereck and Little, 1975).

\section{Summary}

The major valleys of the central Kenai Mountains were probably deglaciated some time before $10,000 \mathrm{yr}$ B.P. By ca. 9,800 yr B.P. (early Holocene), vegetation was developing and peat was beginning to accumulate on glacial deposits left behind by the melting ice. A pollen record from a peat deposit near Tern Lake in the north-central Kenai Mountains suggests that the earliest known postglacial vegetation to develop in that area was a mixture of shrub and herbaceous plants. The shrub types that were present included Alnus, Shepherdia canadensis, Betula, Salix, and Viburnum. The herbaceous component of this pioneering vegetation included Poaceae, Cyperaceae, and a rich variety of herbs and abundant ferns. During one brief interval, between ca. 8,600 and 7,800 yr B.P., Shepherdia canadensis bushes appear to have dominated the vegetation in the Tern Lake area. Additional research is needed to determine whether this reflects a larger regional event, such as a glacial readvance, or was simply the result of a local disturbance of vegetation.

Boreal spruce trees such as Picea glauca, P. mariana, and Betula papyrifera began to colonize the northern Kenai Lowland about 7,800 yr B.P., and began to spread eastward into the valleys of the Kenai Mountains at about the same time. By about 5,300 yr B.P. (mid-Holocene time), boreal spruce trees arrived in the Tern Lake area along with paper birch.

During late Holocene, coastal forest vegetation spread westward across Prince William Sound and began colonizing the east coast of the Kenai Peninsula. By about 2,200 yr B.P., Picea sitchensis and Tsuga mertensiana trees were beginning to colonize the northern and eastern valleys of the Kenai Mountains. Picea sitchensis or Sitka spruce-white spruce hybrids probably reached the Tern Lake area by about 2,000 yr B.P. Tsuga mertensiana trees may have also arrived within a few kilometers of Tern Lake at about that time, but may have colonized valley slopes rather than the valley floor. The mixture of coastal and interior (boreal) plants that began developing during middle Holocene time in the Tern Lake area reached its maximum degree of blending during the past 2,000 years. This mixture of ecologically different floras seems to be the result of the eastern boundary of a transitional climate zone near Tern Lake that favors both the survival of boreal (continental-adapted) plant species as well as many coastal (maritime-adapted) plant species.

A climatic reconstruction for the Gulf of Alaska coast during the Holocene by Heusser and others (1985) indicates that the rapid spread of boreal forest into upper Cook Inlet during the early Holocene coincided with climates that were warmer and drier than the present climate of the region. Their reconstruction also shows that the westward spread of coastal forest into Prince William Sound and eastern Kenai Peninsula during the late Holocene occurred under conditions of a generally cool, wet regional climate (fig. 6). That wet climatic regime favored the westward spread of coastal plant species into unforested areas of Prince William Sound, Turnagain Arm, and the eastern and southern parts of Kenai Peninsula. Whereas late Holocene development of wetter climates appears to have favored the western spread of coastal forest vegetation, those same conditions probably inhibited the further spread of boreal plant species into the eastern and southern Kenai Mountains. A summary of vegetation types recorded in the pollen records from three sites in the region is shown in fig. 6. Hidden Lake represents a site within the partial precipitation shadow of the Kenai Mountains. Its record indicates that the Kenai Lowlands were deglaciated early and its recolonization by vegetation was heavily influenced by boreal plants spreading from the interior.

In contrast, the pollen record from Golden in Prince William Sound (fig. 6) shows how a coastal site in a maritime climate underwent a very different postglacial history. The area appears to have been deglaciated later, and the plants that colonized the area were plants adapted to coastal environments. There were no nearby seed sources for coastal tree species until the late Holocene, so alders, herbs, and ferns 
dominated the vegetation cover for thousands of years until seeds of mountain hemlock and Sitka spruce began spreading from the east about 3,000 yr B.P.

The summary of vegetation types for the Tern Lake peat section (fig. 6) is a record that is intermediate between those of Hidden Lake - with its heavy influence by boreal vegetation - and Golden - where coastal vegetation development is recorded. The Tern Lake area displays a history that represents a mixture of boreal and coastal floras at a site near the eastern range limits of many boreal trees and shrubs.

\section{References Cited}

Ager, T.A., 1983, Holocene vegetational history of Alaska, in Wright, H.E., Jr., ed., Late-Quaternary Environments of the United States. Vol. 2. The Holocene: Minneapolis, University of Minnesota Press, p. 128-140.

Ager, T.A., 1989, History of late Pleistocene and Holocene vegetation in the Copper River basin, south-central Alaska, in Carter, L.D., Hamilton, T.D., and Galloway, J.P., eds., Late Cenozoic History of the Interior Basins of Alaska and the Yukon: U.S. Geological Survey Circular 1026, p. 89-92.

Ager, T.A., 2000, Postglacial vegetation history of the Kachemak Bay area, Cook Inlet, south-central Alaska, in Kelley, K.D., and Gough, L.P., eds., Geologic Studies in Alaska by the U.S. Geological Survey, 1998: U.S. Geological Survey Professional Paper 1615, p. 147-165.

Ager, T.A., and Brubaker, L.B., 1985, Quaternary palynology and vegetational history of Alaska, in Bryant, V., and Holloway, R., eds., Pollen Records of Late-Quaternary North American Sediments: Dallas, Texas, American Association of Stratigraphic Palynologists Foundation, p. 354-384.

Crossen, K.J., 1992, Guide to the Little Ice Age landforms and glacial dynamics in Portage valley and Portage Pass: Field Trip Guide for International Conference on Arctic Margins, September 2-4, 1992, Anchorage, Alaska Geological Society, $46 \mathrm{p}$.

Hartman, C.W., and Johnson, P.R., 1978, Environmental atlas of Alaska: Fairbanks, Alaska, Institute of Water Resources, University of Alaska, $95 \mathrm{p}$.

Heusser, C.J., 1955, Pollen profiles from Prince William Sound and southeastern Kenai Peninsula, Alaska: Ecology, v. 36, p. 185-202.

Heusser, C.J., 1960, Late-Pleistocene environments of North Pacific North America: New York, American Geographical Society Special Publication $35,308 \mathrm{p}$.

Heusser, C.J., 1983, Holocene vegetation history of the Prince William Sound region, south-central Alaska: Quaternary Research, v. 19, p. 337-355.

Heusser, C.J., 1985, Quaternary pollen records from the Pacific Northwest coast: Aleutians to the Oregon-California boundary, in Bryant, V., and Holloway, R., eds., Pollen Records of Late Quaternary North American Sediments: Dallas, Texas, American Association of Stratigraphic Palynologists Foundation, p. 143-165.
Heusser, C.J., Heusser, L.E., and Peteet, D.M., 1985, Late-Quaternary climatic change on the American Pacific coast: Nature, v. 315, p. 485-487.

Hultén, E., 1968, Flora of Alaska and neighboring Territories: Stanford, California, Stanford University Press, 1008 p.

Joint Federal-State Land Use Planning Commission for Alaska, 1973, Major ecosystems of Alaska Map, 1:250,000 scale.

Karlstrom, T.N.V., 1964, Quaternary geology of the Kenai Lowland and glacial history of the Cook Inlet region, Alaska: U.S. Geological Survey Professional Paper 443, 69 p.

Leslie, L.D., 1989, Alaska climate summaries: Alaska Climate Data Center Technical Note No. 5: Anchorage, Alaska, Arctic Environmental Information and Data Center, University of Alaska-Anchorage, $478 \mathrm{p}$.

Peteet, D.M., 1986, Modern pollen rain and vegetational history of the Malaspina Glacier district, Alaska: Quaternary Research, v. 42, p. $100-120$.

Peteet, D.M., 1991, Postglacial migration of lodgepole pine near Yakutat, Alaska: Canadian Journal of Botany, v. 69, p. 786-796.

Péwé, T.L., 1975, Quaternary geology of Alaska: U.S. Geological Survey Professional Paper 835, $145 \mathrm{p}$.

Reger, R.D., 1991, Deglaciation of the Allison-Sawmill Creeks area, southern shore of Port Valdez, Alaska, in Reger, R.D., ed., Short Notes on Alaskan Geology, 1991: Fairbanks, Alaska, Alaska Division of Geological and Geophysical Surveys, Professional Report 111, p. 54-61.

Reger, R.D., and Pinney, D.S., 1996, Late Wisconsin glaciation of the Cook Inlet region with emphasis on Kenai Lowland and implications for early peopling, in Davis, N.Y., and Davis, W.E., eds., Adventures Through Time: Readings in the Anthropology of Cook Inlet, Alaska: Anchorage, Cook Inlet Historical Society, p. 15-35.

Reger, R.D., and Pinney, D.S., 1997, Last major glaciation of Kenai Lowland, in Karl, S.M., Vaughn, N.R., and Ryherd, T.J., eds., 1997 Guide to the Geology of the Kenai Peninsula, Alaska: Anchorage, Alaska Geological Society, p. 54-67.

Reger, R.D., Pinney, D.S., Burke, R.M., and Wiltse, M.A., 1996, Catalog and initial analyses of geologic data related to middle to late Quaternary deposits, Cook Inlet region, Alaska: Fairbanks, Alaska, Alaska Division of Geological and Geophysical Surveys, Report of Investigations 95-6, 188 p., 5 plates.

Rymer, M.J., and Sims, J.D., 1982, Lake-sediment evidence for the date of deglaciation of the Hidden Lake area, Kenai Peninsula, Alaska: Geology, v. 10, p. 314-316.

Schmoll, H.R., Yehle, L.A., and Updike, R.G., 1999, Summary of Quaternary geology of the municipality of Anchorage, Alaska: Quaternary International, v. 60, p. 3-36.

Sirkin, L.A., and Tuthill, S.J., 1987, Late Pleistocene and Holocene deglaciation and environments of the southern Chugach Mountains, Alaska: Geological Society of America Bulletin, v. 99, p. 376-384.

Viereck, L.A., and Little, E.L., Jr., 1972, Alaska trees and shrubs: U.S. Department of Agriculture Forest Service Handbook 410, 265 p. 
Viereck, L.A., and Little, E.L., Jr., 1975, Atlas of United States trees. Volume 2, Alaska trees and common shrubs: U.S. Department of Agriculture Forest Service Miscellaneous Publication 1293, 127 p.

Wiles, G.C., Barclay, D.J., and Calkin, P.E., 1999, Tree-ring-dated "Little Ice Age" histories of maritime glaciers from western Prince William Sound, Alaska: The Holocene, v. 9, p. 163-173.

Wiles, G.C., and Calkin, P.E., 1990, Neoglaciation in the southern Kenai
Mountains, Alaska: Annals of Glaciology, v. 14, p. 319-323.

Wiles, G.C., and Calkin, P.E., 1993, Neoglacial fluctuations of an iceberg-calving glacier resolved with tree rings (Kenai Fjords National Park, Alaska): Quaternary International, v. 18, p. 35-42.

Wiles, G.C., and Calkin, P.E., 1994, Late Holocene, high-resolution glacial chronologies and climate, Kenai Mountains, Alaska: Geological Society of America Bulletin, v. 106, p. 281-303.

Reviewers: P. Carrara, L.E. Strickland 



\title{
Biogeochemistry of Arsenic and Cadmium, Fortymile River Watershed, East-Central Alaska
}

\author{
By Larry P. Gough, James G. Crock, Warren C. Day, and Jim Vohden
}

\section{Abstract}

Biogeochemical investigations of arsenic, cadmium, and other trace elements are being conducted in the Fortymile placer-gold mining district of east-central Alaska. Using geologic and hydrologic framework studies, the cycling of trace elements is examined in the sub-arctic boreal forest ecosystem of the Interior Highlands Ecoregion. These studies seek to define the relative contribution to the ecosystem of various geogenic (natural) sources. Study sites are located on five of the major bedrock units: Paleozoic(?) metamorphosed plutonic, volcanic, and sedimentary rocks (and associated marble units), and younger (Jurassic) monzodioritic and tonalitic rocks. The chemistry of $\mathrm{A}, \mathrm{B}$, and $\mathrm{C}$ soil horizons, willow (Salix glauca) and alder (Alnus crispa) leaf and twig tissue, and feather moss (Hylocomium splendens) tissue were examined and compared with the geochemistry of underlying bedrock units. The nearly homogeneous chemistry of our soils data from throughout the study area reflects the ubiquitous presence of glacial loess. In general, element concentration differences were more easily defined for arsenic than for cadmium among both the rock units and the soils developed over these rock units. Arsenic concentrations are much higher in the $\mathrm{C}$ soil horizon than in any of the rock units studied and tend to increase with increasing soil depth and soil horizon. The opposite trend is true for cadmium in soils - cadmium concentrations decrease with increasing soil depth and soil horizon. The total concentration of arsenic and cadmium in plant tissue was not found to be strongly correlated with rock units. Alder growing over intrusive rocks has less arsenic than from supracrustal units. Whereas the concentration of arsenic varies little among plant species and tissue types, the variability in cadmium is large (nearly two orders of magnitude). The cadmium variability is due mainly to the ability of willow to act as a bioaccumulator for cadmium. This tendency may adversely affect the health of browsing animal populations that greatly depend on willow (such as beaver, hare, and moose). The calculated baseline for arsenic in this watershed is gener- ally below levels found in similar materials statewide, whereas cadmium baselines are somewhat elevated.

\section{Introduction}

This report describes biogeochemical results for arsenic and cadmium and is part of a larger study integrating geology, hydrology, and geochemistry in the Fortymile mining district, east central Alaska (see also Gough and others, 1997; Crock and others, 1999; Day and others, 2000; Gamble and others, this volume; Wanty and others, 2000). These studies provide a regional framework and interpretive data for land management agencies involved in assessing the relative contribution of natural (geogenic) vs. anthropogenic geochemical landscape patterns and processes. State and Federal regulations require that the degree of adverse impact by mining, if any, be quantified. The U.S. Geological Survey (USGS) and the Alaska Department of Natural Resources are cooperating in this project and are providing the scientific data needed for upcoming decisions that involve State and Federal land-use options and their regulations. Arsenic, and to a lesser extent cadmium, are considered to have particular environmental importance in the Fortymile mining district (Gough and others, 1997; Wanty and others, 2000) as well as farther west in the Fairbanks district (Goldfarb and others, 1999). Both are trace elements that have natural geogenic sources. In addition, their mobility and bioavailability (degree to which the element is free for uptake or assimilation by an organism) can be accentuated by human activities (Gough and others, 1979; Newman and Jagoe, 1996). The elements have the potential to be toxic in aquatic as well as terrestrial environments and both have State and Federal regulations that govern their discharge from industrial and mining sources (Smith and Huyck, 1999).

The primary objectives of this study were to (1) determine the regional baseline geochemistry in waters, soils, rocks, sediments, and selected terrestrial vegetation for a section of the Fortymile River watershed currently being mined 


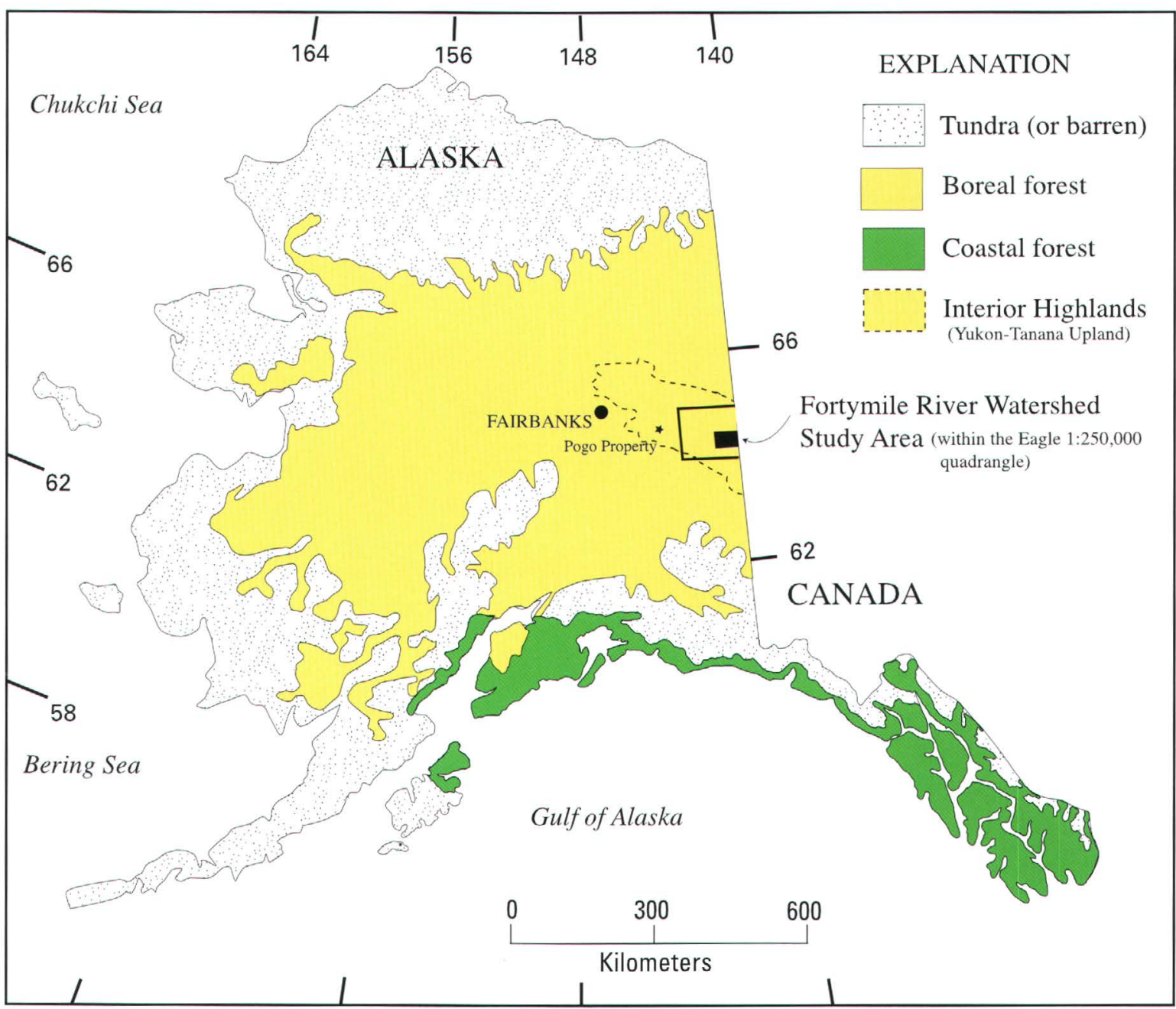

Figure 1. Location within Alaska of the Fortymile River study area relative to the three generalized major vegetation types (modified from Van Cleve and others, 1983; Ager, 2000).

for placer gold (both suction dredge and "cat" or caterpillar tractor-aided mechanized operations); (2) assess the influence of geology on soil and vegetation geochemical signatures; (3) determine the movement of metals through boreal subarctic upland and riverine forest ecosystems; (4) using both geologic and hydrologic frameworks, define the relative contribution of the various natural sources of arsenic and cadmium and other environmentally important trace elements to the landscape.

This study focuses on a portion of the Fortymile River watershed (fig. 1) in the southeast corner of the Eagle 1:250,000-scale quadrangle. The study area lies within the Interior Highlands Ecoregion (Gallant and others, 1995) and is part of the remote lower Fortymile River drainage (fig. 2). This region is underlain by metamorphic rocks of the Yukon-Tanana lithotectonic terrane of east-central Alaska (see Day and others, 2000, for a review of the geologic setting). The resource management of the region is complex due to diverse ownership and the many land-use options. In 1980, the Fortymile River and its major tributaries were designated a Wild and Scenic Corridor by the Alaska National Interest Lands Conservation Act (ANILCA). Jurisdiction of the land bordering the watershed continues to be the responsibility of the U.S. Bureau of Land Management. The Alaska Department of Natural Resources has jurisdiction over the management of the recreation uses of the river (rafting, canoeing, and fishing) and mining. The U.S. Environmental Protection Agency is also involved because mining discharges require compliance with the National Pollutant Discharge Elimination System (NPDES) of the Clean Water Act. Finally, both sport and subsistence hunting are important in the region and are managed by Federal and State agencies.

Placer gold was first discovered in the Fortymile mining district in 1886 and has been mined there ever since. Yeend (1996) gives a summary of the gold mining history of the placers of the Fortymile River region and provides details of the Tertiary and Quaternary deposits that support those placers. Although there are no current non-placer drift or open-pit goldmining operations in the area, within the past 3 years there 


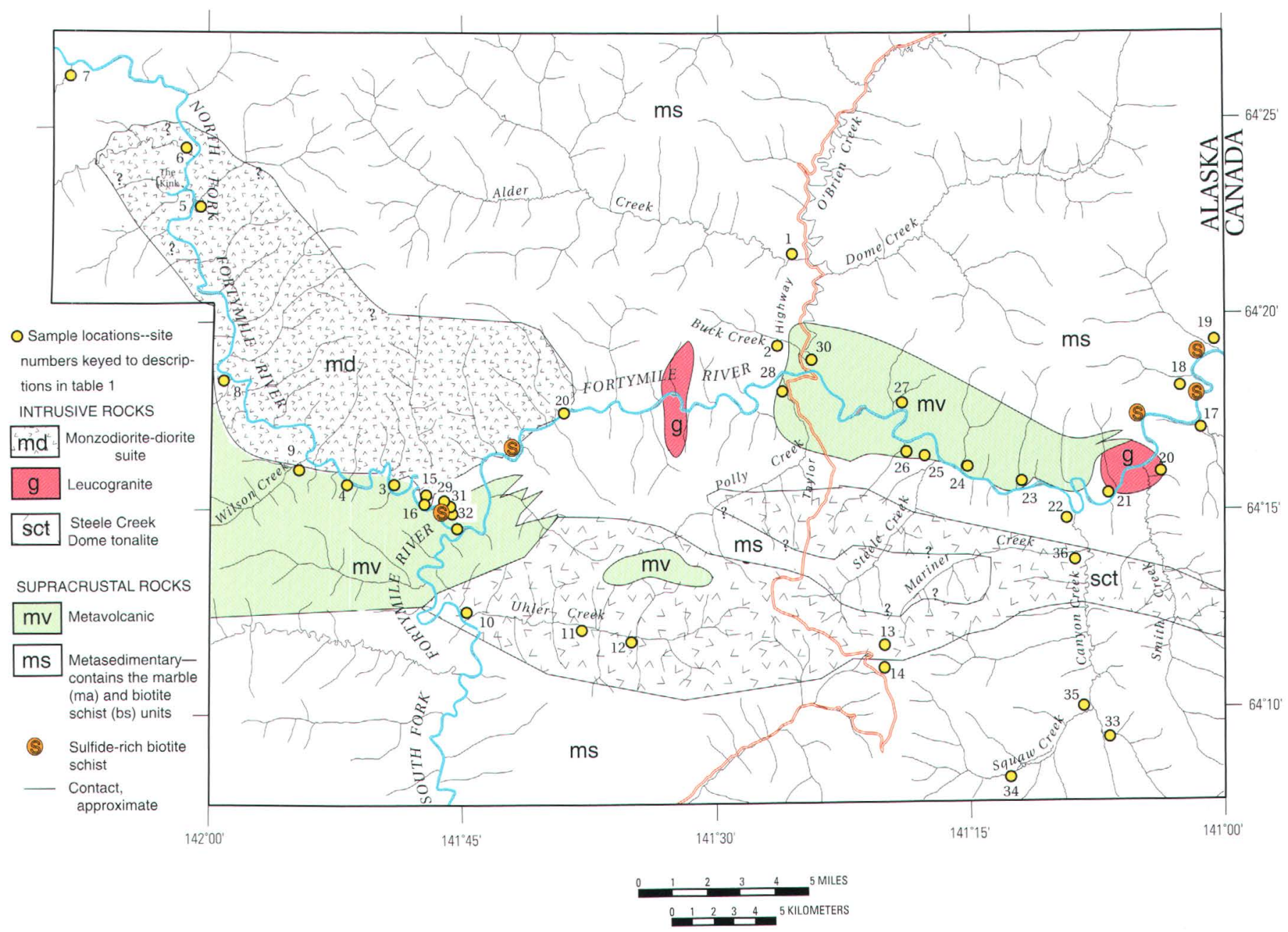

Figure 2. Generalized geology and study site locations within the Fortymile River watershed, east-central Alaska (modified from Wanty and others, 2000; Day and others, 2000).

has been a dramatic increase in exploration and claim-staking activity in the region (Szumigala and Swainbank, 1999). This renewed interest is due mainly to the discovery of highly mineralized quartz bodies, several hundred meters below the surface, on the Pogo property in the Goodpaster River area of the Big Delta quadrangle (fig. 1) (Smith and others, 1999).

\section{Landscape Setting}

\section{Terrain, Vegetation, and Hydrology}

The Interior Highlands Ecoregion is characterized by vegetated, rounded, low mountains with scattered sparsely vegetated to barren high peaks (as high as about 2,200 m). The vegetation of the region is classified by Viereck and Little
(1972) as closed spruce-hardwood forest containing tall to moderately tall white and black spruce (Picea glauca and $P$. mariana, respectively), paper birch (Betula papyrifera), aspen (Populus tremuloides), and balsam poplar (Populus balsamifera). Fires are common, due mainly to lightning strikes, and most of our study sites showed evidence of past fire disturbance. The area has a continental climate and the weather station at Eagle (70 km north of the study area) records the following 12-month-average weather values for the period 1949-1998 - precipitation: 302 mm (12 inches); minimum temperature: $-10.8^{\circ} \mathrm{C}\left(12.5^{\circ} \mathrm{F}\right)$; maximum temperature: $2.1^{\circ} \mathrm{C}$ $\left(36^{\circ} \mathrm{F}\right)$; snowfall: $140 \mathrm{~cm}$ (55 inches).

The Fortymile River drains mostly subarctic boreal forest, tundra, and muskeg having discontinuous permafrost (fig. 1). Even soils not underlain by permafrost are commonly frozen to various depths for much of the growing season. Over the year, discharge by the Fortymile River and its tributaries is highly variable (Kostohrys, and others, 1999) and reflects 
(1) a rapid spring ice-break-up period (April-June), (2) runoff from storm events (the frozen nature of the terrain accentuates the runoff potential), (3) summer dry periods, and (4) freeze-up (October-November). Maximum flow on the mainstem in May can exceed $340 \mathrm{~m}^{3} \mathrm{~s}^{-1}$ (where $1 \mathrm{~m}^{3} \mathrm{~s}^{-1}=$ $35.3107 \mathrm{ft}^{3} \mathrm{~s}^{-1}$ ) and base flow during January, February, and March is $<1 \mathrm{~m}^{3} \mathrm{~s}^{-1}$. There is usually some flow on the mainstem in mid-winter from ground water sources. On April 2, 1998 , at a period of near maximum freeze-up, we measured several springs along the North Fork that were discharging at about $0.005 \mathrm{~m}^{3} \mathrm{~s}^{-1}$, whereas during that same period total flow (measured just above the confluence with the South Fork) was between $0.59 \mathrm{~m}^{3} \mathrm{~s}^{-1}$ and $0.76 \mathrm{~m}^{3} \mathrm{~s}^{-1}$. Breakup at the Fortymile Bridge ( $25 \mathrm{~km}$ below the confluence) did not occur until the end of April 1998. The rivers and streams of this region are dark ("black-water") due to dissolved organic matter. The water is, however, low in conductivity $\left(\sim 90-220 \mu \mathrm{S} \mathrm{cm}^{-1}\right)$, has $\mathrm{pH}$ values that are commonly above 7.3 , and turbidity values that seldom exceed 2 nephelometric turbidity units (ntu; the standard unit for turbidity measurement) (Crock and others, 1999; Wanty and others, 2000).

\section{Geology}

Bedrock and associated surficial deposits control the primary minerals and chemical elements available for weathering that ultimately enter hydrologic and biologic systems. Therefore, understanding the geologic framework of the area is the first step in assessing the effect that mining operations, or other human activities, might have on the Fortymile River watershed. To meet the objectives of this study, a new reconnaissance geologic map has been compiled (Day and others, 2000) (fig. 2, this study) and builds on the previous work of Dusel-Bacon and others (1995), Foster (1976), Foster and Keith (1969), and Foster and others (1994). Recent detailed mapping by Szumigala and others (2000) supersedes the mapping of Day and others (2000). There is immense local variation in the bedrock type. As such, the bedrock was characterized for each site in this study to help constrain the chemistry of the underlying rock unit. This effort was conducted to address two specific needs: (1) the characterization of regional lithologic units that underlie the study area; and (2) the definition of any possible mineralized and (or) altered zones that might occur in the study area.

In general, the bedrock of the Fortymile River area is composed of metamorphosed supracrustal rocks intruded by various types of granitoids and ultramafic rocks. The supracrustal rocks are composed of biotite schist, biotite-amphibole schist, quartzite, marble, sulfide-rich biotite schist, and pelite. The protoliths for these supracrustal rocks include graywacke, mafic volcanic and compositionally equivalent intrusive rocks, quartz-rich sandstone, sulfide-rich siliciclastic sediments, and pelitic sediments, respectively. All of the supracrustal rocks are cut by late metamorphic sulfide-bearing quartz veins. The supracrustal rocks are interpreted to have been deposited on a continental margin and (or) distal to an island-arc complex in a back-arc basin.

Intruding the metamorphic supracrustal rocks are three main granitoid suites. The Steele Creek Dome tonalite is a composite body of foliated biotite-hornblende tonalitic orthogneiss containing country-rock rafts of paragneiss. Two mica \pm garnet-bearing leucogranite bodies locally invade the supracrustal rocks. This latter sequence was intruded by an Early Jurassic(?) hornblende monzodiorite-diorite suite.

The entire rock package experienced Jurassic-aged metamorphism and tectonism. The area has been subjected to at least three phases of deformation. The first produced a strong regional schistosity and local mineral lineations. The second deformation generated tight to isoclinal folds, folded the earlier schistosity and mineral lineations, and was accompanied by a weak axial-planar cleavage and both mineral and stretching lineations. The youngest deformation recognized folded the ductile fabric elements about south-plunging, east-vergent, open folds and records east-directed tectonic shortening (Day and others, 2000).

\section{Soils}

An understanding of soil genesis and composition is critical to the interpretation of our geochemical data. We are particularly interested in understanding the mobility of metals and their uptake by plants within a well-defined geologic/ pedologic context. Soils at our study sites are classified as Cryaquepts (Inceptisols) having variable amounts of undecomposed (fresh) and decomposed organic matter in the A horizon (Van Cleve and others, 1983, note that about 78 percent of the land area of Alaska is occupied by Inceptisols). Greater than 70 percent of our sites were near saturation at the time of collection and permafrost was commonly observed from 15 to $50 \mathrm{~cm}$ below the surface. Most sites had silty-loam to finesandy-loam A soil horizons with abundant root penetration. The A horizon was usually less than $10 \mathrm{~cm}$ in thickness and light brown in color. Several of the sites had ash/charcoal layers (usually less than $2 \mathrm{~cm}$ in thickness) within the $\mathrm{A}$ horizon indicating past fire disturbance. The B horizon was usually about as thick as the A horizon, lighter in color, and contained moderate root volume. $\mathrm{C}$ soil horizons commonly extended below 20 to $40 \mathrm{~cm}$ in depth, and consisted of fine to coarse sand with small blocks of angular bedrock and few roots. The presence of silt (glacial loess) in the soil horizons was universal and is assumed to have an important influence on soil chemistry. Silt-loam-textured soils are common in interior Alaska and are derived from mainly micaceous loess laid down during the Holocene (Daniel Muhs, oral commun., 1999) and during the last glacial maximum (Van Cleve and others, 1983). Although it is possible that some of the soils developed from alluvium, most sites were well above contemporary flood levels on slopes that do not exceed 15 percent. Geomorphic signs of down-slope soil movement (solifluction lobes and outwash fans), however, indicate that the upper horizons of these 
soils were mostly colluvial in origin having residuum predominating in the $\mathrm{C}$ horizon only. Cryoturbation, most commonly signaled by the presence of hummocks, was observed only on a very few of our sites where the forest was sparse and permafrost was shallow.

\section{Arsenic}

Arsenic migration in soils, sediments, and waters is limited by high levels of sulfide in reducing environments and by its tendency to sorb onto clays, hydroxides, and organic matter in oxidizing environments. We assume that because the soils in the Fortymile River watershed are periodically saturated with water, arsenic can occur as arsenite; however, the much less toxic and less soluble (and thus less bioavailable) arsenate form should predominate in the more common oxidizing soil conditions (Adriano, 1986). In acid soils, such as those in our study site, there is a tendency to form ironand aluminum-arsenates. These complexes are highly insoluble unless the soil $\mathrm{pH}$ is raised above about 7.5 (Gough and Severson, 1995). Also, in oxidizing soils, arsenate is generally strongly sorbed onto amorphous hydrous iron- and manganese-oxides. The region is extremely remote and study sites were chosen away from any historically disturbed areas; therefore, we expect that a very high percentage of the arsenic found in the Fortymile watershed is geogenic (as opposed to anthropogenic). Wanty and others (2000) found that for two suction dredge placer mining operations studied on the Fortymile River, neither accentuated arsenic transport in the water column beyond the area immediately downstream of the dredge. Arsenic, especially as arsenopyrite, is associated with sulfides in both the metasedimentary and metavolcanic rocks of Paleozoic(?) age, as well as in the younger intrusive igneous rocks (Crock and others, 1999; Gamble and others, this volume). Other than through the oxidation and hydrolysis of primary arsenic-bearing minerals, it is unknown how major contributions of arsenic could be made to this boreal forest environment.

\section{Cadmium}

Cadmium in soils within the study area is derived from both the weathering of the primary metasedimentary and metavolcanic bedrock and glacial loess. In these types of residual soils, cadmium is commonly adsorbed by various clay minerals and also by calcium- and magnesium-carbonates. Cadmium does not form highly stable complexes with organic matter. In addition, in these cold boreal forest soils where microbial decomposition rates are low, the cadmium that is tied up in organic matter probably remains immobile for some time (Adriano, 1986). Cadmium can form many compounds of low solubility by precipitation as carbonates, hydroxides, and phosphates. This process is less important, however, in our low pH, generally low-carbonate soils. Cadmium is readily leached from soils at $\mathrm{pH}$ values below about 5.0 (Severson and Shacklette, 1988), especially if the soils have a sandy texture. Therefore, its increased solubility and bioavailability in oxic, acidic soils may potentially result in an increase in the amount of cadmium absorbed and translocated by plants in this area. Zinc has close geochemical similarities with cadmium and competes for exchange sites in soil. These soils are not particularly high in $\mathrm{Zn}$, and, therefore, $\mathrm{Zn}$ probably has a minimal adverse influence on cadmium bioavailability.

\section{Field and Laboratory Methods}

Field sampling was conducted between June 20-29, 1997, and between June 17-25, 1998. By sampling at the same time of year we hoped to minimize biogeochemical variability associated with seasonal (temporal) factors. Field site selection criteria, sample collection methods, and laboratory methods were consistent from year to year.

Field number, geographic position, general geology, and description notes are listed in table 1 for each of our study sites in the Fortymile River watershed. Field numbers indicate the year that the site was visited (1997 or 1998). Selection of the study site was based on geology, aspect (southern exposures being preferred because of greater depth to frozen ground, where present), and vegetation community; sites were also $<10$ vertical meters above stream (or river) channels. Vegetation and soil sites were in upland conifer stands, usually dominated by white spruce and birch, having an understory of mixed shrubs and a dense ground cover of mosses and scattered lichens. Obvious flood plains and areas of debris-flow were avoided. Soil pits were dug to the $\mathrm{C}$ horizon or to a depth dictated by the presence of frozen ground. The unavailability of a particular sample material at a given site explains the variability in the number of samples collected (table 2). For example, the presence of shallow permafrost prevented collection of C-horizon soil for some sites. At each site, approximately $1 \mathrm{~kg}$ of $\mathrm{A}, \mathrm{B}$, and $\mathrm{C}$ soil horizon material was collected. Approximately $200 \mathrm{~g}$ dry weight of the leaf and stem material were collected of the young, growing branches (approximately the terminal-most $10 \mathrm{~cm}$ ) of Salix glauca (grayleaf willow) and Alnus crispa (green alder). Samples were composites of several plants in the immediate vicinity of the soil pit. In addition, a large, integrated sample of the ubiquitous feather moss (Hylocomium splendens) was also collected. At four sites duplicate soil and vegetation samples were collected within 50 to $100 \mathrm{~m}$ of each other to help assess local spatial variability.

Methods of sample storage, shipping, preservation, drying, preparation for analysis, and analysis are described elsewhere and follow the procedures outlined in Crock and others (1999), Arbogast (1996), and Gough and Crock (1997). Concentrations of arsenic and cadmium in soil and plant material were determined by inductively coupled plasma-mass 
[Coordinates are in decimal degrees. Map number keyed to figure 2. Rock types: ms, metasedimentary; mv, metavolcanic; md, hornblende diorite, monzodiorite, and tonalite; ma, marble; sct, tonalite orthogneiss]

\begin{tabular}{|c|c|c|c|c|c|}
\hline $\begin{array}{l}\text { Field } \\
\text { number }\end{array}$ & $\begin{array}{c}\text { Map } \\
\text { number }\end{array}$ & Site description & $\begin{array}{l}\text { Latitude } \\
\text { (N.) }\end{array}$ & $\begin{array}{l}\text { Longitude } \\
\text { (W.) }\end{array}$ & Rock type \\
\hline $97 \mathrm{AK} 0 \mathrm{~A}$ & 1 & North bank Alder Cr. $0.5 \mathrm{~km}$ upstream of confluence with $\mathrm{O}^{\prime}$ Brien $\mathrm{Cr}$. & 64.4053 & 141.4191 & $\mathrm{~ms}$ \\
\hline 97AK01 & 2 & West bank Buck Cr. on L. Taylor property & 64.3174 & 141.4216 & $\mathrm{~ms}$ \\
\hline 97AK02 & 3 & North Fork of the Fortymile River, down stream of dredge operation no. 1 and Wilson Creek & 64.2602 & 141.8431 & $\mathrm{mv}$ \\
\hline 97AK03 & 4 & North Fork of the Fortymile River, down stream of dredge operation no. 2 and Wilson Creek & 64.2690 & 141.8911 & $\mathrm{mv}$ \\
\hline 97AK04 & 5 & East bank North Fork of the Fortymile River, $1.6 \mathrm{~km}$ downstream from The Kink & 64.3763 & 142.0190 & md \\
\hline 97AK05 & 6 & South bank Hutchinson Creek near the confluence with the Fortymile River & 64.3989 & 142.0193 & md \\
\hline 97AK06 & 7 & South bank Bullion Creek near the confluence of the Fortymile River & 64.4378 & 142.1423 & $\mathrm{~ms}$ \\
\hline 97AK07 & 8 & First major unnamed creek upstream from the confluence of Wilson Creek and the North Fork & 64.3047 & 141.9807 & md \\
\hline 97AK08 & 9 & South bank Wilson Creek near the confluence with the North Fork & 64.2704 & 141.9071 & $\mathrm{mv}$ \\
\hline 97АK09 & 10 & North bank Uhler Creek near the confluence with the South Fork & 64.2035 & 141.7525 & sct \\
\hline $97 \mathrm{AK} 10$ & 11 & South bank Uhler Cr. $6.4 \mathrm{~km}$ upstream of South Fork near old tailings of cat-mining operation & 64.1988 & 141.6229 & sct \\
\hline 97AK11 & 12 & South bank Uhler Cr. $8.5 \mathrm{~km}$ upstream of South Fork & 64.3148 & 141.5823 & sct \\
\hline 97AK12 & 13 & West-facing side of hill along Taylor Highway in granite-gneiss terrain & 64.2503 & 141.4002 & sct \\
\hline $97 \mathrm{AK} 13$ & 14 & West-facing side of hill along Taylor Highway in mafic-schist terrain & 64.2078 & 141.3922 & $\mathrm{~ms}$ \\
\hline 98AK01 & 15 & Tertiary alluvial gravel bench upslope from North Fork on north bank & 64.3169 & 141.4206 & $\mathrm{~ms}$ \\
\hline $98 \mathrm{AK} 02$ & 16 & Quaternary alluvial gravel bench upslope from North Fork on north bank & 64.2550 & 141.7996 & $\mathrm{~ms}$ \\
\hline 98AK03 & 17 & East bank Moose Cr. $0.8 \mathrm{~km}$ upstream of confluence with Fortymile River & 64.2878 & 141.0248 & $\mathrm{~ms}$ \\
\hline 98AK04 & 18 & North bank Snow Cr. $50 \mathrm{~m}$ upstream of confluence with Fortymile River & 64.3123 & 141.0337 & $\mathrm{~ms}$ \\
\hline 98AK05 & 19 & East bank Sam Patch Cr. $50 \mathrm{~m}$ upstream of confluence with Fortymile River & 64.3194 & 141.0050 & $\mathrm{~ms}$ \\
\hline 98AK06 & 20 & East bank Smith Cr. $50 \mathrm{~m}$ upstream of confluence with Fortymile River & 64.2686 & 141.0928 & $\mathrm{~ms}$ \\
\hline 98AK07 & 21 & West bank Discovery Cr. $50 \mathrm{~m}$ upstream of confluence with Fortymile River & 64.2662 & 141.1117 & $\mathrm{~ms}$ \\
\hline 98AK08 & 22 & West bank Canyon Cr. 20 m upstream of confluence with Fortymile River & 64.2594 & 141.1600 & $\mathrm{~ms}$ \\
\hline 98AK09 & 23 & East bank Nugget $\mathrm{Cr} .30 \mathrm{~m}$ upstream of confluence with Fortymile River & 64.2645 & 141.2111 & $\mathrm{mv}$ \\
\hline $98 \mathrm{AK} 10$ & 24 & East bank Twin Cr. $50 \mathrm{~m}$ upstream of confluence with Fortymile River & 64.2669 & 141.2669 & $\mathrm{mv}$ \\
\hline $98 \mathrm{AK} 11$ & 25 & One km south of Fortymile River and $1 \mathrm{~km}$ west of Steele Cr. & 64.2766 & 141.2857 & $\mathrm{mv}$ \\
\hline $98 \mathrm{AK} 12$ & 26 & East bank Bow Cr. $100 \mathrm{~m}$ upstream of confluence with Fortymile River & 64.2863 & 141.3192 & $\mathrm{mv}$ \\
\hline $98 \mathrm{AK} 13$ & 27 & East bank Flat $\mathrm{Cr} .100 \mathrm{~m}$ upstream of confluence with Fortymile River & 64.3023 & 141.3370 & $\mathrm{mv}$ \\
\hline $98 \mathrm{AK} 14$ & 28 & East bank Polly Cr. $50 \mathrm{~m}$ upstream of confluence with Fortymile River & 64.3127 & 141.4364 & $\mathrm{mv}$ \\
\hline $98 \mathrm{AK} 15$ & 29 & Top of $300 \mathrm{~m}$ bluff on east bank of Fortymile River & 64.2519 & 141.7856 & $\mathrm{~ms}$ \\
\hline $98 \mathrm{AK} 16$ & 30 & North bank O'Brien Cr. $300 \mathrm{~m}$ east of Taylor Highway & 64.3253 & 141.4175 & $\mathrm{mv}$ \\
\hline $98 \mathrm{AK} 17$ & 31 & Top of $300 \mathrm{~m}$ bluff on east bank of Fortymile River & 64.2518 & 141.7745 & $\mathrm{~ms}$ \\
\hline 98AK18 & 32 & Top of $300 \mathrm{~m}$ bluff on east bank of Fortymile River & 64.2600 & 141.7708 & $\mathrm{~ms}$ \\
\hline $98 \mathrm{AK} 19$ & 33 & North bank Hall $\mathrm{Cr} .50 \mathrm{~m}$ upstream of confluence with Canyon $\mathrm{Cr}$. & 64.1596 & 141.1262 & ma \\
\hline $98 \mathrm{AK} 20$ & 34 & Upslope on north bank of Squaw Cr. $4.8 \mathrm{~km}$ west of confluence with Canyon Cr. & 64.1373 & 141.2365 & $\mathrm{~ms}$ \\
\hline $98 \mathrm{AK} 21$ & 35 & West bank Squaw Cr. $30 \mathrm{~m}$ west of confluence with Canyon Cr. & 64.1736 & 141.1342 & ma \\
\hline $98 \mathrm{AK} 22$ & 36 & South bank Mariner Cr. $100 \mathrm{~m}$ upstream of confluence with Canyon Cr. & 64.2441 & 141.1408 & sct \\
\hline
\end{tabular}


Table 2. Summary statistics for element concentrations in plants and soils, Fortymile River watershed study area (dry weight basis).

[The six replicated samples (Crock and others, 1999) used for QA/QC estimations were averaged prior to calculation of the summary statistics. Except for the GD, values reported to two significant figures]

\begin{tabular}{|c|c|c|c|c|c|c|}
\hline \multirow[b]{2}{*}{$\begin{array}{l}\text { Material, } \\
\text { element }\end{array}$} & \multirow{2}{*}{$\begin{array}{l}\text { Lower limit } \\
\text { of analytical } \\
\text { determination } \\
\text { (LLD) }\end{array}$} & \multirow[b]{2}{*}{$\begin{array}{l}\text { Analytical } \\
\text { detection }^{-} \\
\text {ratio }^{1}\end{array}$} & \multicolumn{3}{|c|}{ Summary statistics } & \multirow[b]{2}{*}{$\begin{array}{c}\text { Expected } 95 \% \\
\text { range (baseline) } \\
(\mathrm{ppm})^{2}\end{array}$} \\
\hline & & & $\begin{array}{c}\text { Geometric } \\
\text { mean (GM) (ppm) }\end{array}$ & $\begin{array}{c}\text { Geometric } \\
\text { deviation (GD) }\end{array}$ & $\begin{array}{l}\text { Observed } \\
\text { range (ppm) }\end{array}$ & \\
\hline \multicolumn{7}{|l|}{ Alder twig } \\
\hline As & $0.02^{3}$ & 23:31 & --4 & -- & $<0.02-0.46$ & -- \\
\hline $\mathrm{Cd}$ & 0.01 & $31: 31$ & 0.029 & 1.83 & $0.010-0.029$ & $0.009-0.097$ \\
\hline \multicolumn{7}{|l|}{ Alder leaf } \\
\hline As & $0.03^{3}$ & $21: 31$ & -- & -- & $<0.03-0.44$ & -- \\
\hline $\mathrm{Cd}$ & 0.01 & $31: 31$ & 0.031 & 1.70 & $0.011-0.093$ & $0.011-0.090$ \\
\hline \multicolumn{7}{|l|}{ Willow twig } \\
\hline As & 0.02 & 25:32 & -- & -- & $<0.02-0.76$ & -- \\
\hline $\mathrm{Cd}$ & 0.01 & $32: 32$ & 0.78 & 1.97 & $0.17-3.5$ & $0.20-3.0$ \\
\hline \multicolumn{7}{|l|}{ Willow leaf } \\
\hline As & 0.03 & $19: 32$ & -- & -- & $<0.03-1.0$ & -- \\
\hline $\mathrm{Cd}$ & 0.01 & $32: 32$ & 1 & 1.78 & $0.22-2.4$ & $0.32-3.2$ \\
\hline \multicolumn{7}{|l|}{ Moss } \\
\hline As & 0.02 & $36: 36$ & 0.22 & 1.71 & $0.099-1.2$ & $0.076-0.64$ \\
\hline $\mathrm{Cd}$ & 0.01 & $36: 36$ & 0.14 & 1.68 & $0.046-0.42$ & $0.05-0.40$ \\
\hline \multicolumn{7}{|l|}{ A-horizon } \\
\hline As & 0.02 & 34:34 & 2.2 & 2.23 & $0.53-19$ & $0.44-11$ \\
\hline $\mathrm{Cd}$ & 0.01 & $34: 34$ & 0.43 & 1.92 & $0.14-2.7$ & $0.11-1.6$ \\
\hline \multicolumn{7}{|l|}{ B-horizon } \\
\hline As & 0.02 & $33: 33$ & 4.6 & 1.75 & $1.9-23$ & $1.5-14$ \\
\hline $\mathrm{Cd}$ & 0.01 & $33: 33$ & 0.25 & 1.89 & $0.08-1.5$ & $0.07-0.89$ \\
\hline \multicolumn{7}{|l|}{ C-horizon } \\
\hline As & 0.02 & $31: 31$ & 7.1 & 1.81 & $2.8-101$ & $2.2-23$ \\
\hline $\mathrm{Cd}$ & 0.01 & $31: 31$ & 0.2 & 2.08 & $0.08-2.5$ & $0.05-0.86$ \\
\hline
\end{tabular}

1 Number of uncensored analytical values (reported above the LLD) / total number of analyses.

$2 \mathrm{GM} / \mathrm{GD}^{2}$ to $\mathrm{GM} \times \mathrm{GD}^{2}$ (baseline as proposed by Tidball and Ebens, 1976).

3 LLD can vary between groups of samples because of among-sample ash-yield percentage variability.

4 --, not calculated because of presence of censored (below the LLD) values.

spectrometry (Crock and others, 1999; Lichte and others, 1986). National Institute of Standards and Technology and internal USGS reference materials and laboratory-made duplicate samples were submitted to the laboratory as part of each suite of samples. USGS quality assurance and control practices were followed and are provided in more detail elsewhere (Crock and others, 1999; Arbogast,1996). Individual sample results for the analyses of arsenic and cadmium in vegetation and soils, as well as for numerous other elements not discussed in this report, are given in Crock and others (1999). The vegetation and soil samples were ashed prior to the determination of most elements, and element concentration values reported on an ash-weight basis by convention were converted to a dryweight basis before data analysis.

\section{Results}

\section{Soil and Geology}

Percentile arithmetic box plots of the concentration of arsenic and cadmium in the various major rock units of the Fortymile River watershed study area are presented in figure 3. Also presented are the data for A, B, and C soil horizons. The data in the figure are distributed according to percentile groupings. The specific rock units of importance to this study, as identified in figure 2 , are the metasedimentary rocks (ms), which include marble (ma), biotite schist, and sulfide-rich biotite schist; metavolcanic rocks of basaltic composition (mv); 


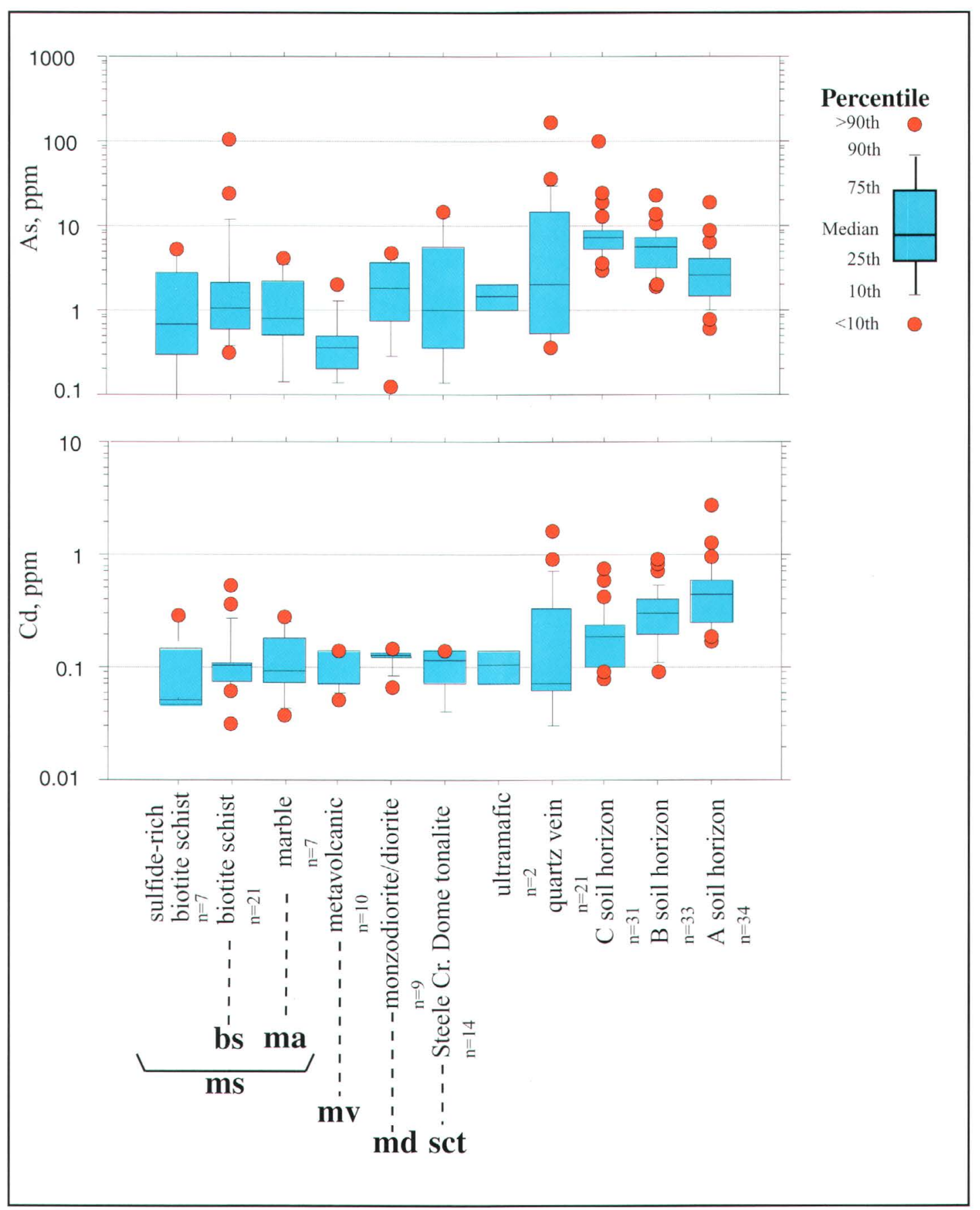

Figure 3. Percentile box plots of arsenic and cadmium concentrations in rock units and soil horizons, Fortymile River watershed study area. Each dot is a value greater than the 90th percentile. Selected rock units keyed to figure 2 include supracrustal rocks (biotite schist, $\mathrm{ms}$; marble, ma; basaltic metavolcanic, mv) as well as intrusive rocks (monzodiorite and diorite, md; Steele Creek Dome tonalite, sct).

ultramafic intrusive rocks (um); monzodiorite and diorite (md); Steele Creek Dome tonalite (sct); and mesothermal quartz veins.

When comparing all rock units (fig. 3), the arsenic data shows greater variability (two orders of magnitude) than do the cadmium data (less than an order of magnitude). Of particular note is the quartz vein material that contains high concentrations of both elements. The quartz vein occurrences, although common, are volumetrically small across the study area, and we believe that none of our soil sampling sites were developed over rock masses containing significant amounts of quartz veining. Also of interest is the geochemistry of the sulfide-rich 
biotite schist rocks. This unit was easily identified where it occurred in outcrop, appearing as iron-stained, oxidized zones (Day and others, 2000) (fig. 2, this report). Several of these zones are being examined extensively for their mineralogy and as possible loci for trace metals, especially arsenic, entering both terrestrial and aquatic ecosystems (for example, sites 29 , 31, and 32 in fig. 2) (Gamble and others, this volume).

The variability in the concentration of arsenic and cad- mium in the rock units is of particular interest to the biogeochemical studies due to the nature of the soils that have developed over the rock types. The variation in both arsenic and cadmium in the rock units is less than that seen between the different soil horizons (fig. 3). Arsenic and cadmium concentrations in the three sampled soil horizons (fig. 3) show distinct among-horizon differences and narrow within-horizon concentration variability for both elements. This plot is of all

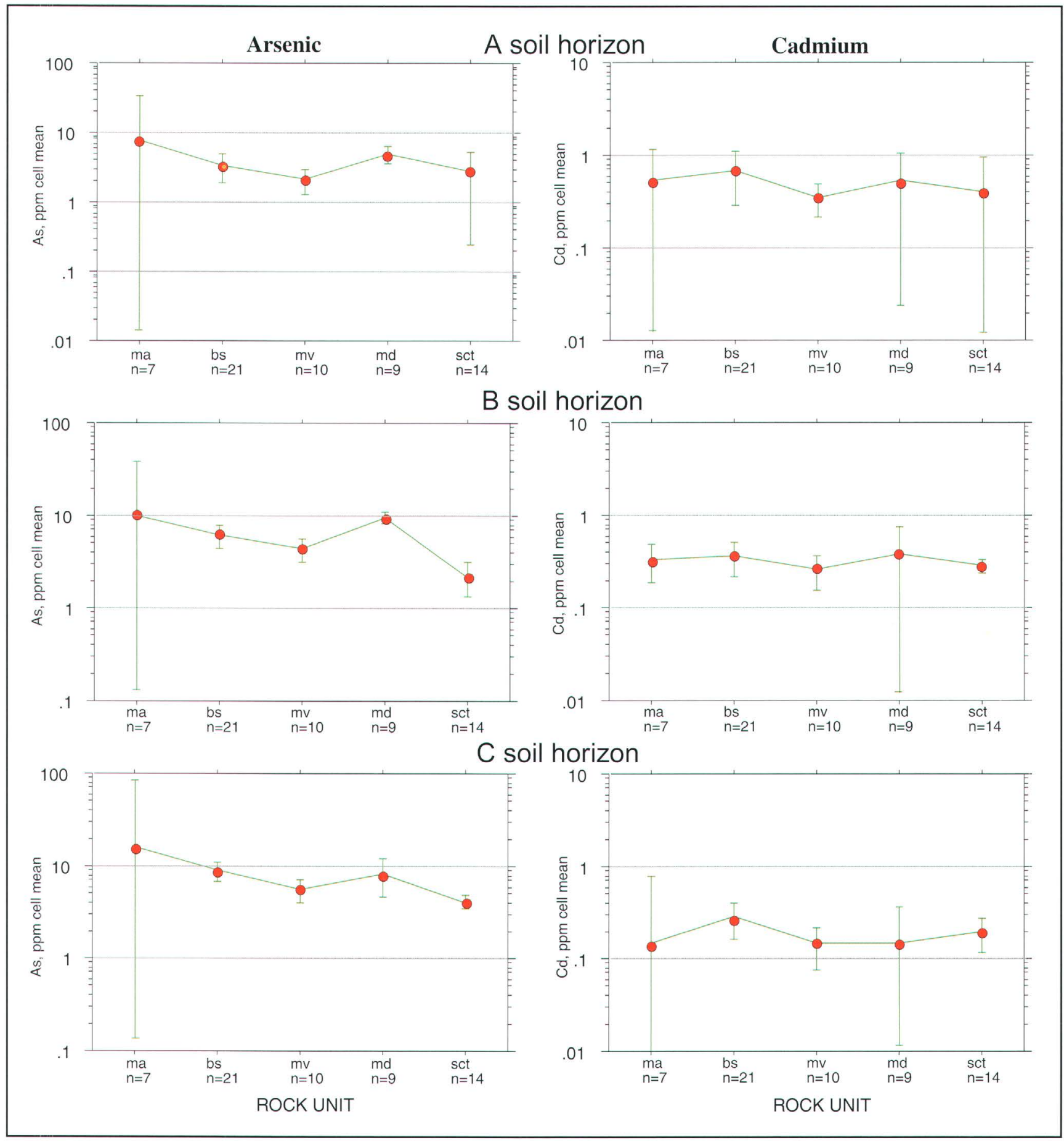

Figure 4. Mean concentration of arsenic and cadmium in A, B, and C soil horizons over five lithologic units, Fortymile River watershed study area (rock units same as for figure 2). 
of the soils data regardless of rock unit. The concentration of arsenic decreases from the $\mathrm{C}$ to the A horizon whereas the opposite is true for cadmium. These arsenic and cadmium trends seem consistent with what should be expected from the general geochemical mobility discussions presented above for these elements in these soils.

To investigate bedrock control on soil chemistry, the soils were separated based on bedrock that underlies each study site (fig. 4; rock unit abbreviations are keyed to fig. 2). The error bars ( \pm one standard deviation) for the mean of each unit and each soil horizon commonly overlap and show, in general, that these sample populations can not be considered geochemically distinct for arsenic and cadmium. This is particularly true for the marble (ma) and monzodiorite/diorite (md) data. There are, however, some important apparent differences among both the soil horizons and rock units. First, concentrations of arsenic increase with increasing soil depth whereas the concentrations of cadmium decrease with increasing soil depth. This is especially true for the supracrustal ms and mv units. Second, the variability in the concentration of arsenic among rock units is small and the small deviations allow for inter-rock unit comparisons. For example, the range of arsenic in the two granitoid intrusive units (md and sct) is similar; however, the range of arsenic in the two supracrustal units ( $\mathrm{ms}$ and $\mathrm{mv}$ ) appear different. Finally, there is variability in the concentration of cadmium among rock units; however, the overlying soil horizons do not show much variability for a given soil horizon and all have greater cadmium concentrations than bedrock (fig. 3).

\section{Arsenic and Cadmium Biogeochemical Baselines}

Federal and State agencies involved in the management of public lands, where mining is a land-use option, are required to assess the relative geochemical impact of the disturbance. This can only be accomplished when regional geochemical baselines have been determined. We define baseline here as the 95 percent expected range, as proposed by Tidball and Ebens (1976), which is the concentration range calculated by: $\mathrm{GM} / \mathrm{GD}^{2}$ to $\mathrm{GM} \times \mathrm{GD}^{2}$, where $\mathrm{GM}$ (geometric mean) is the antilogarithm of the mean of logarithmic values and GD (geometric deviation) is the antilogarithm of the standard deviation of the logarithmic values. Table 2 gives the GM, GD, observed range, and expected 95 percent range for the concentration of arsenic and cadmium in the five plant tissues and the three soil horizons.

Because we found no measurable differences in the chemistry of plants growing over different lithologic units, no effort was made in the baseline calculations to segregate the data based on these units. The "analytical detection ratio," therefore, is the number of uncensored analytical values (above the lower limit of detection, LLD) used in the calculations for each of the sample media to the total number of analyses.
In those instances where censored values occur, the GM and GD were not calculated. The baseline calculation is only truly valid when the regional (broad-scale) geochemical variability is large compared to the local (site-scale) variability (Tidball and Ebens, 1976). Because we cannot statistically define the magnitude of the variability at different scales in the geochemical data, this study may not conform to this criterion. The discussion in the next section will argue, however, that broad-scale variability (variability between rock units) may only be important in the soils data but not the plant data. Nevertheless, these data (table 2) are presented as a "snapshot in time" and can be used for comparison with data for these same elements in similar materials in similar boreal forest ecoregions.

In general, the calculated concentration baselines for arsenic in soils and vegetation are well within the observed ranges reported for Alaska (Gough and others, 1988; Gough and others, 1991) and are not considered unusual. Values for cadmium, however, are slightly higher (a factor of about two when compared to other areas).

\section{Arsenic and Cadmium Bioavailability}

As discussed above, arsenic is apparently tightly bound in the lower soil horizons in our study area and does not migrate into the upper soil horizons (fig. 4). Cadmium, however, appears more mobile than arsenic, having been moved vertically by plant uptake and deposited in the A horizon through plant-material decay. Soil $\mathrm{pH}$, slow organic matter decomposition rates, and the probable absence of carbonate precipitates would all favor cadmium solubility and uptake by plants.

Because arsenic is present as an oxyanion, its bioavailability is enhanced by soils that are oxic and have aboveneutral $\mathrm{pH}$ values. Soils in the study area show Fe mottling and alternate between being fully saturated and being partially drained. Therefore, the $\mathrm{pH}$ of our soils (4.8-6.2), along with the presence of abundant organic matter and high levels of total iron and aluminum, would favor the formation of organically bound arsenic as well as iron- and aluminum-arsenates. In general these soils are not expected to favor arsenic bioavailability, and the fact that arsenic is not preferentially found in the organic-rich upper soil horizons would tend to support this supposition. At this point in our studies we believe, therefore, that the increased levels of arsenic with increasing soil depth is a reflection of decreased mobility into the upper soil horizons. The specific nature of the sequestering of arsenic in these soils awaits future sequential extraction studies, column leach experiments, and X-ray diffraction analyses.

Box plots of the concentration of arsenic and cadmium in the collected plant material, and repeated for the soil-horizon samples, are shown in figure 5. Arsenic has very little variability among the shrub species for either the leaf or twig tissue. Arsenic concentrations in moss tissue, however, are five or six times greater than the arsenic values in shrub material. 


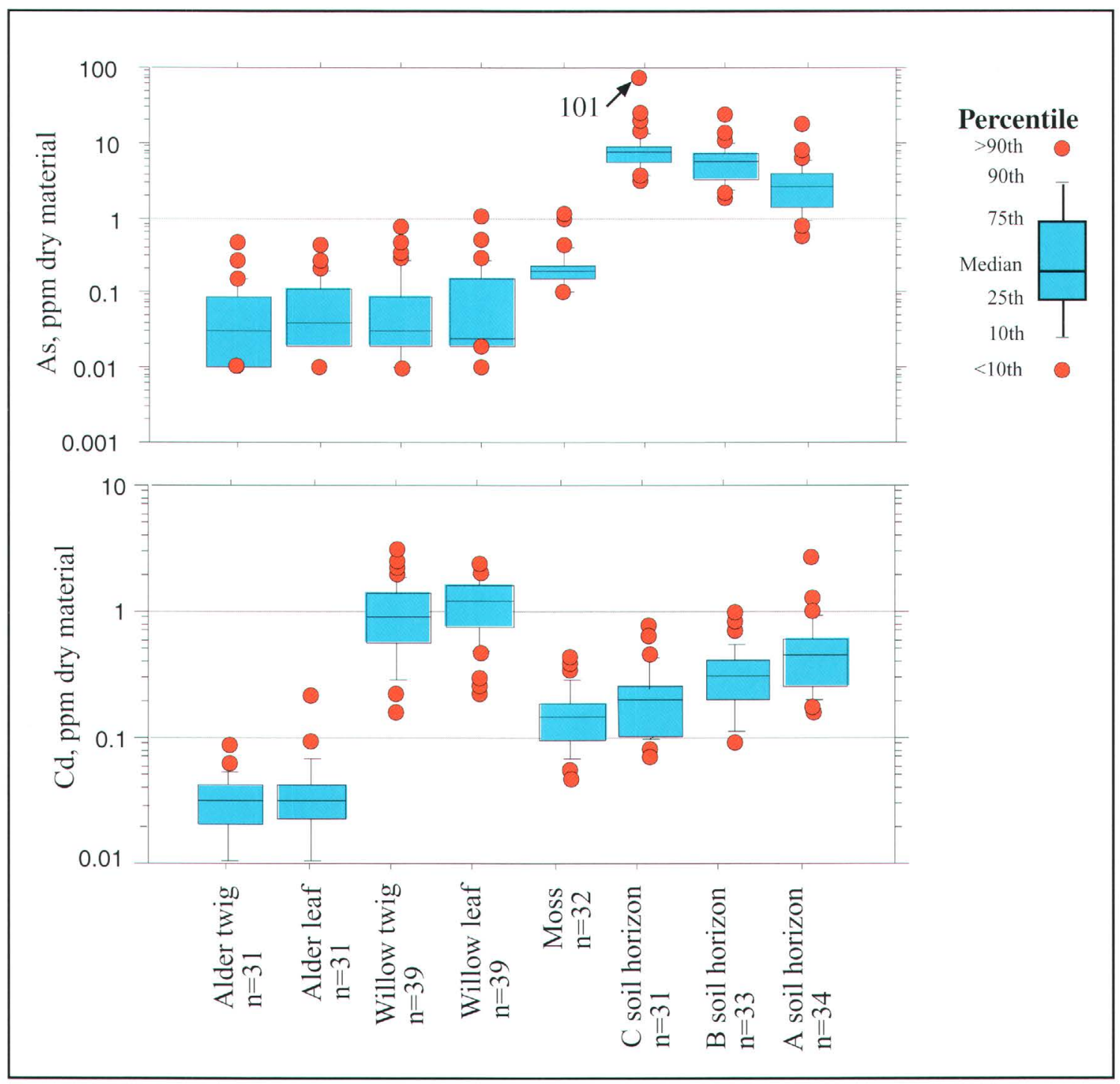

Figure 5. Percentile box plots of arsenic and cadmium concentrations in plant tissue and soil horizons, Fortymile River watershed study area. One value (101 ppm) falls outside the plot boundary.

Arsenic concentrations in the soils are almost two orders of magnitude greater than those found in the plants, and, like the discussion in the paragraph above, suggests that arsenic is not highly bioavailable. In contrast, the cadmium box plots show that the level of cadmium in willow tissue is much greater than in either the alder tissue or the three soil horizons. We have noted in the past that willow seems to be a bioaccumulator of cadmium (Gough and others, 1991), and these data support that observation. The implications that this bioaccumulation might have on the health of animals that depend on willow for browse (for example, moose, grouse, ptarmigan, and hare) are open to speculation. Recently, Larison and others (2000) reported cadmium toxicity in populations of white-tailed ptarmigan in Colorado that feed on willow buds. They report concentrations of cadmium in willow growing in the affected "ore-belt" region that are similar to values we report (table 2; fig. 5). Two research questions come to mind - what is the physiological limit ("barrier"), if any, to cadmium uptake by willow, and under what environmental conditions can one expect to find maximum uptake?

Cadmium concentrations in moss are larger than in alder and arsenic concentrations in moss are larger than in either alder or willow. The moss, Hylocomium splendens, is circumboreal in distribution and has been used extensively in both Scandinavia and the United States as a biomonitor of airborne metal deposition (see, for example, Puckett, 1988; Berg and others, 1995). Physiologically, mosses obtain very little of their nutrient and non-nutrient elements from their immediate substrate. Instead, elements are absorbed directly into their leafy tissue from what is dissolved from wind-blown soil or 


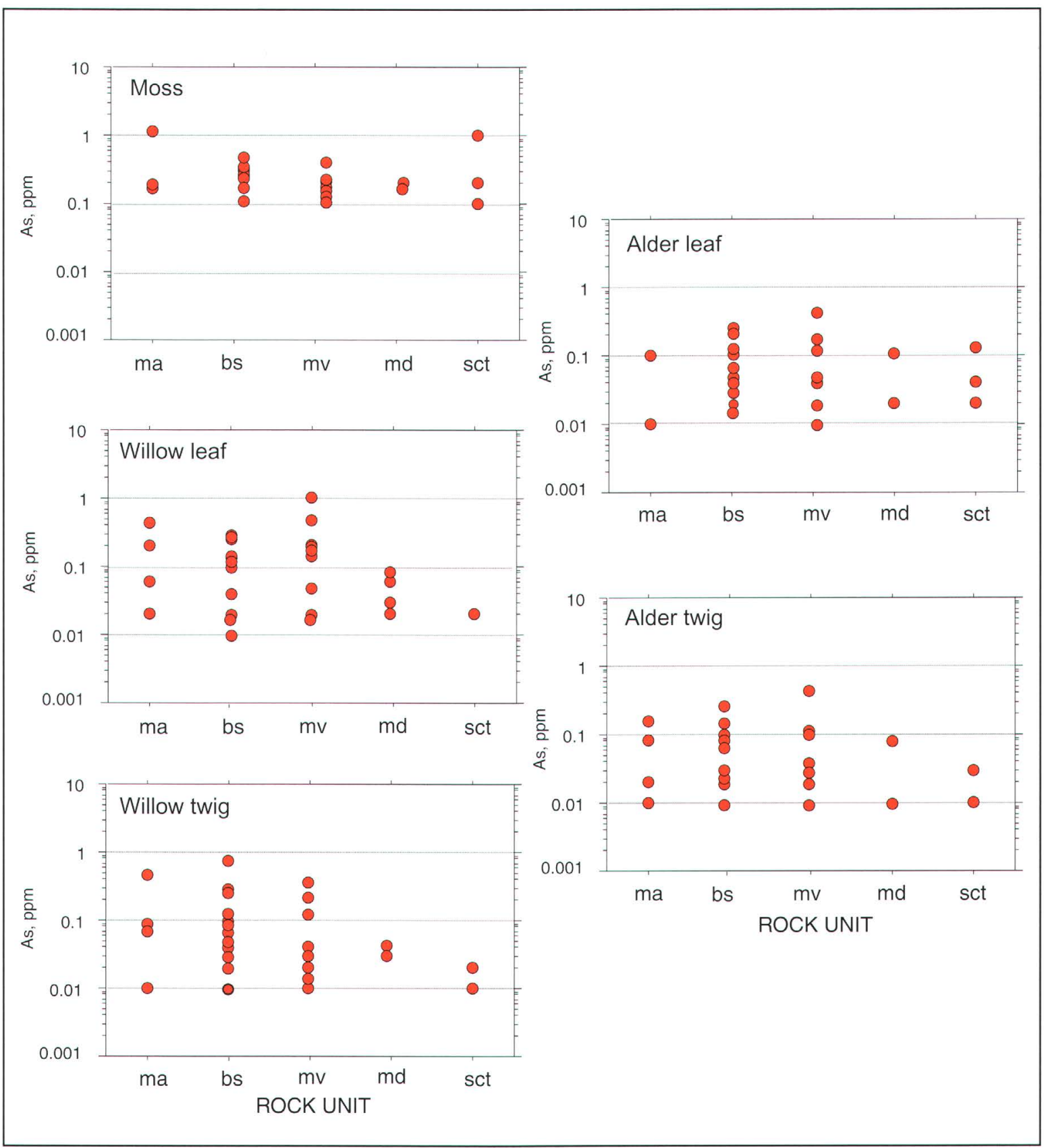

Figure 6. Scatter diagram of arsenic levels in plant materials growing over five lithologic units, Fortymile River watershed study area (rock units same as for figure 2).

from precipitation and forest-canopy throughfall. The moss data suggest that in this boreal forest ecosystem, a certain proportion of the arsenic and cadmium that is bioavailable is coming from airborne sources.

Scatter diagrams of the concentration of arsenic and cadmium, respectively, in plants growing in soils developed over the five major rock types are presented in figures 6 and 7. These data indicate that no important differences exist in the chemistry of plants collected among the various rock units. This is not surprising because plant inorganic chemistry seldom reflects the total inorganic chemistry of bedrock (Gough and others, 1980). Nevertheless, by examining Enrichment Factors (EF, below), relations between bedrock and soil chemistry and plant chemistry can be deduced.

Enrichment Factors (EF) were calculated to measure the magnitude of element uptake in alder, willow, and moss relative to element bioavailability. This technique has also been used to assess possible geogenic vs. anthropogenic additions to plant chemistry when plants have been employed as trace element contamination biomonitors (Gough and others, 1994). 


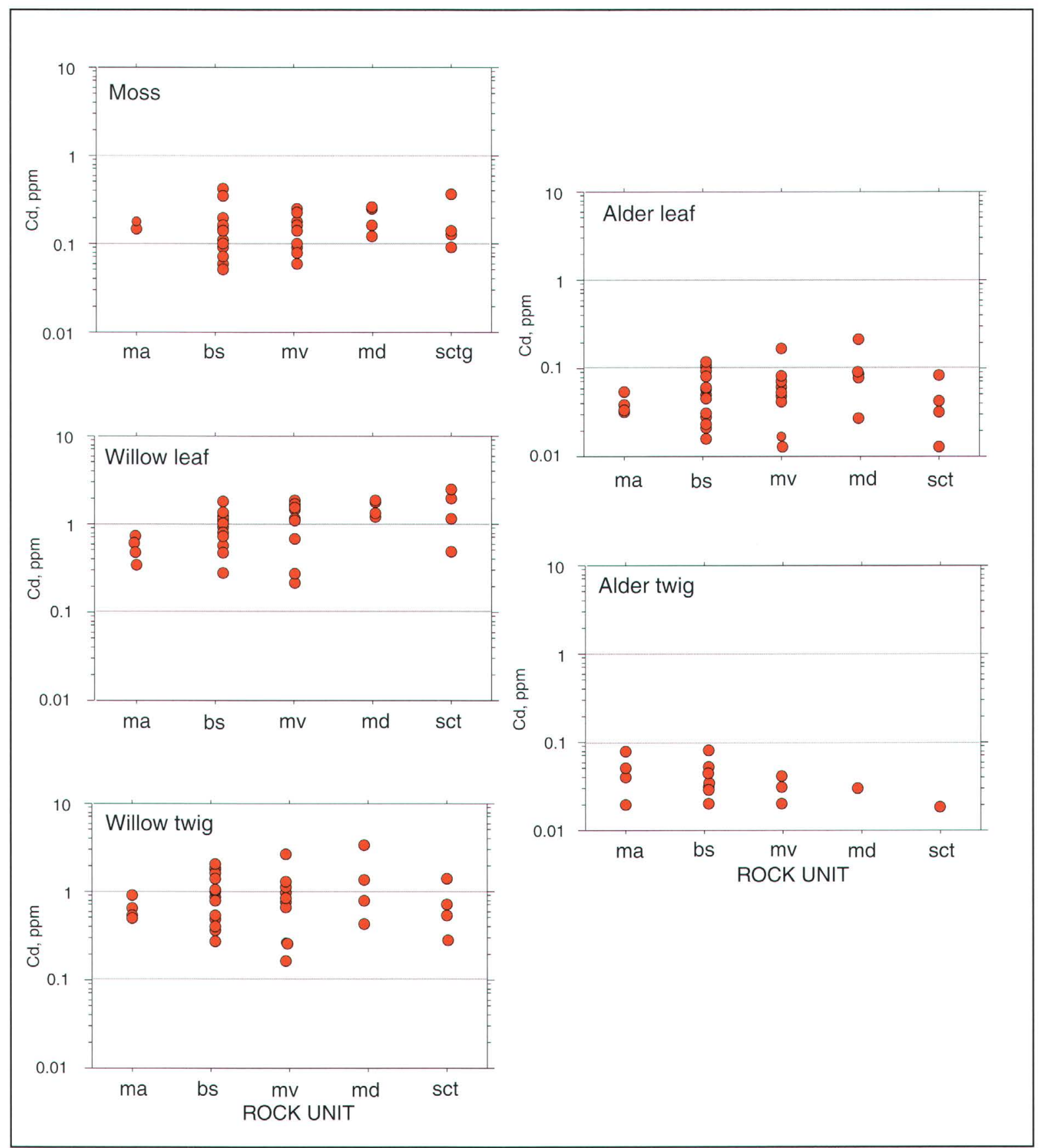

Figure 7. Scatter diagram of cadmium levels in plant materials growing over five lithologic units, Fortymile River watershed study area (rock units same as for figure 2).

The calculation takes the form:

$$
\mathrm{EF}=\frac{[\mathrm{X}] \text { in plant } /[\mathrm{Ce}] \text { in plant }}{[\mathrm{X}] \text { in soil/ } / \mathrm{Ce}] \text { in soil }}
$$

where $[\mathrm{X}]$ and $[\mathrm{Ce}]$ are the concentrations of the element

of concern and of cerium, respectively, in plant material, relative to their concentrations in soil.

This procedure normalizes the data with respect to a geochemical reference element (in this case cerium). Cerium is used here because it is a lithogenic light-rare-earth element and because in slightly acid soils it is relatively non-mobile and unavailable for plant uptake. For example, an EF of 60 means that the plant is 60 times more enriched in a given element 

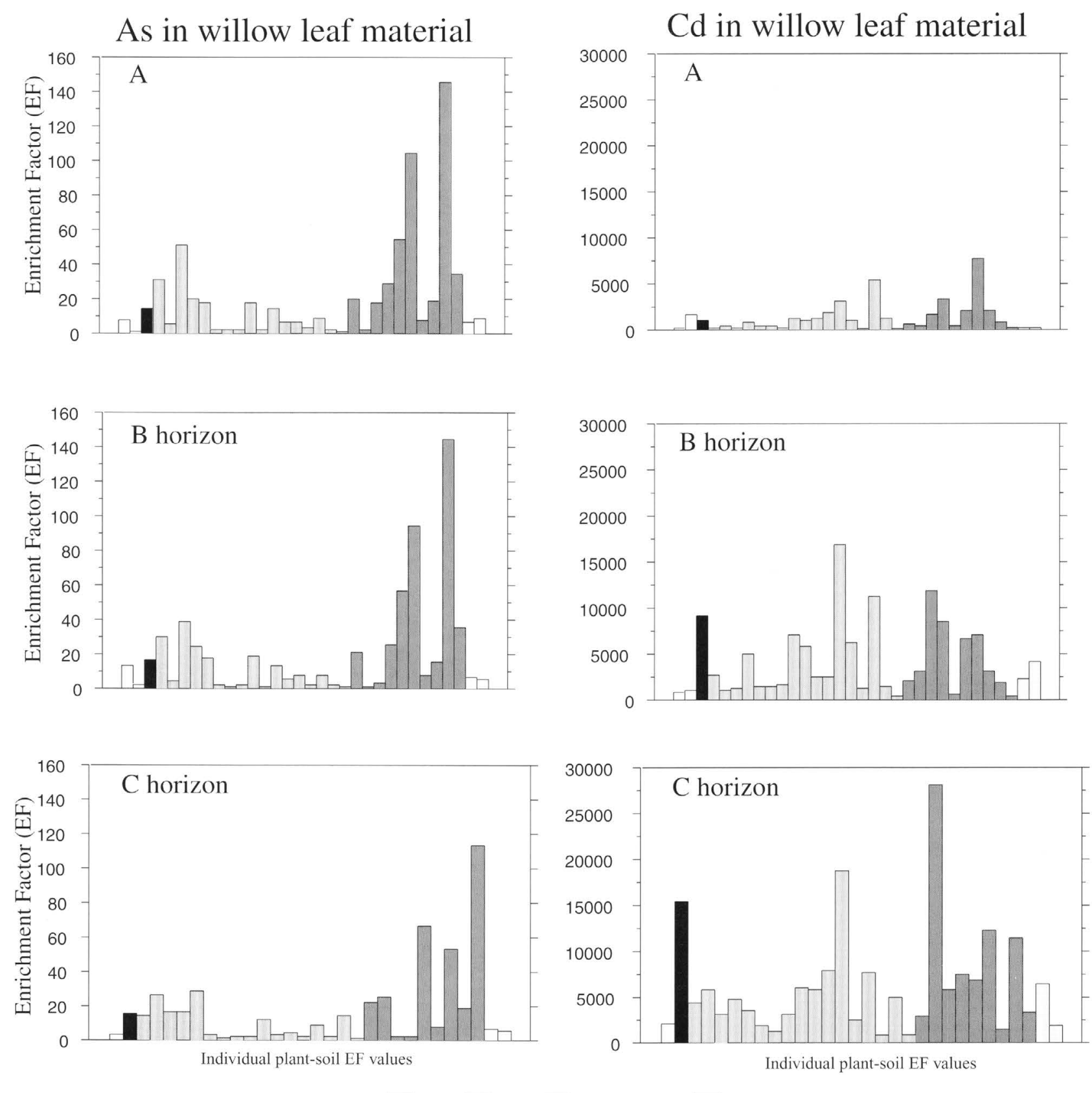

$\square$ ma $\square$ ms $\square$ ms $\square$ mv $\square$ sct

Major rock units (keyed to fig. 2)

Figure 8. Enrichment factors for arsenic and cadmium in willow leaf material for $A, B$, and $C$ soil horizons developed over five major rock units.

compared to the substrate. Assuming that the plant material has been properly cleaned before analysis, the EF is a measure of the relative uptake of an element from its substrate-a sort of "bioavailability" assessment.

Enrichment factor bar plots for arsenic and cadmium in individual samples ( $x$-axis) of willow leaf, alder leaf, and moss tissue for each of the soil horizons developed over the five major rock units are given in figures 8, 9, and 10. Only a few samples represent rock units ma, md, and sct and the EF scales can vary greatly among the figures. Figure 8 shows that arsenic concentrations in willow leaf material are enriched relative to bedrock levels for the mv rock unit as compared to the other rock units. No difference in EF values between soil horizons is noted. In contrast, EF values for cadmium show a marked soil-horizon difference increasing with depth. This difference reflects the greater concentration of cadmium in the upper soil 


\section{As in alder leaf material}
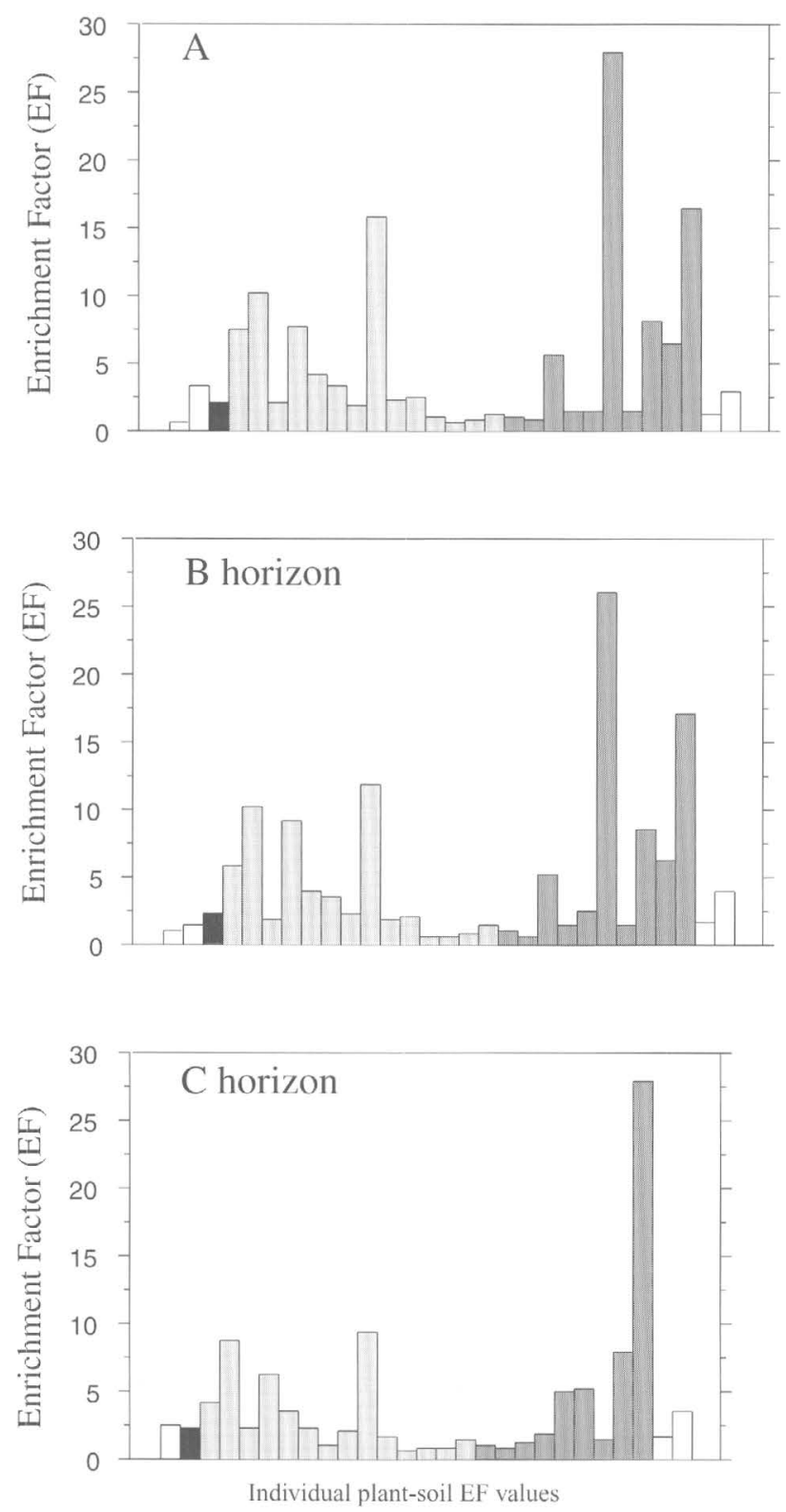

$\mathrm{Cd}$ in alder leaf material
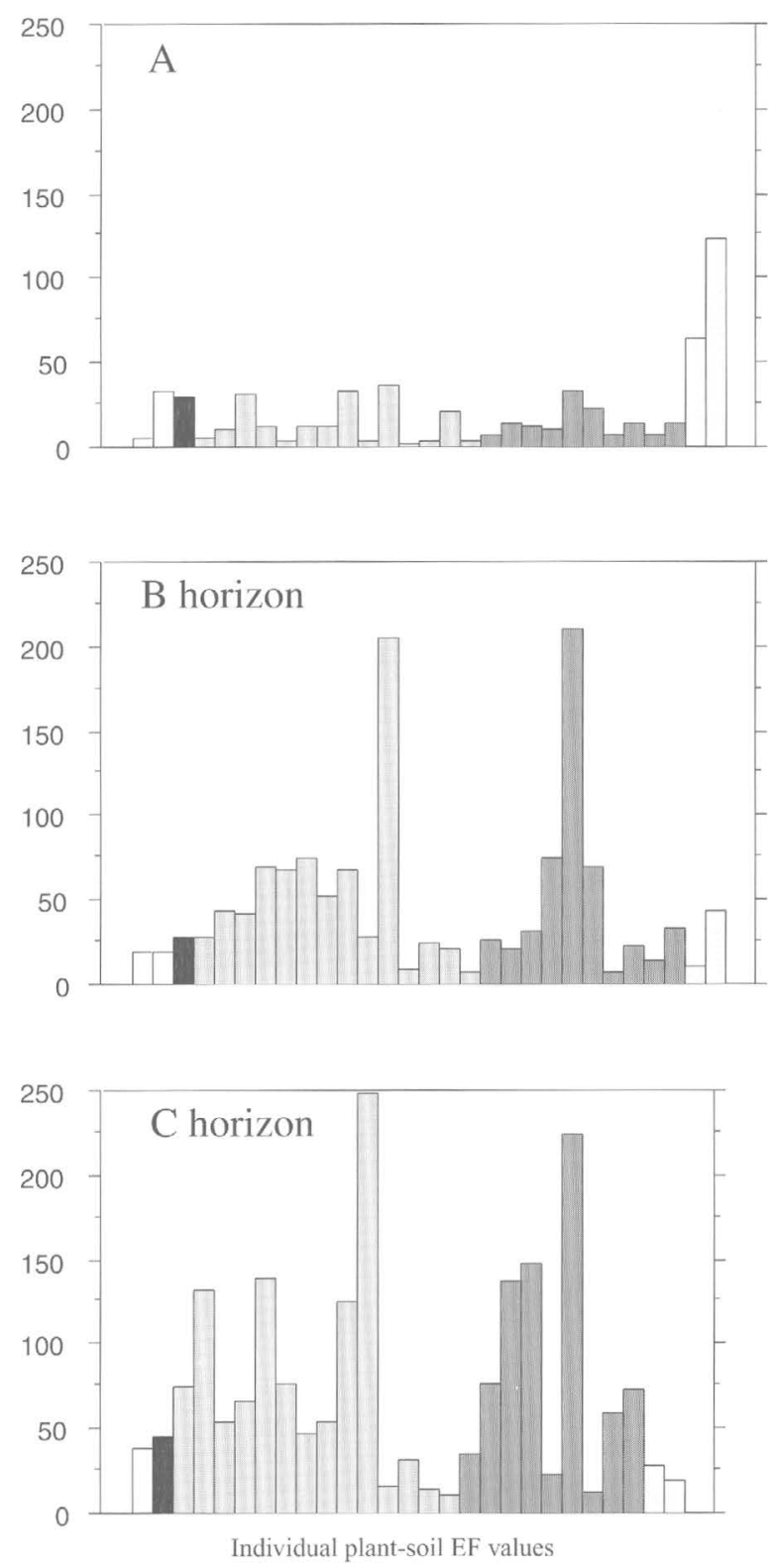

$\square$ ma $\square$ m $\square$ ms $\square$ mv $\square$ sct

Major rock units (keyed to fig. 2)

Figure 9. Enrichment factors for arsenic and cadmium in alder leaf material for $A, B$, and $C$ soil horizons developed over five major rock units.

horizons. The trend is true for all rock units.

Enrichment factor bar plots for arsenic and cadmium in alder leaf material are given in figure 9. These data are similar in general trend to the willow data. Arsenic shows no soilhorizon differences but may show rock unit differences (the mv unit has the greatest EF values and range of values). Of interest, however, are the large EF values for the ms and mv units compared to the other rock units. In general, these EF values indicate that alder tissue has a greater tendency to accumulate cadmium relative to the substrate when growing over $\mathrm{ms}$ and mv. This tendency is much less in overall magnitude than for cadmium in willow as is indicated by the difference in the scales of the $y$-axes (two orders of magnitude).

Moss EF values for arsenic and cadmium are presented in figure 10. No real differences are noted for EF values between rock units for either element. Also, the smallest EF values are 

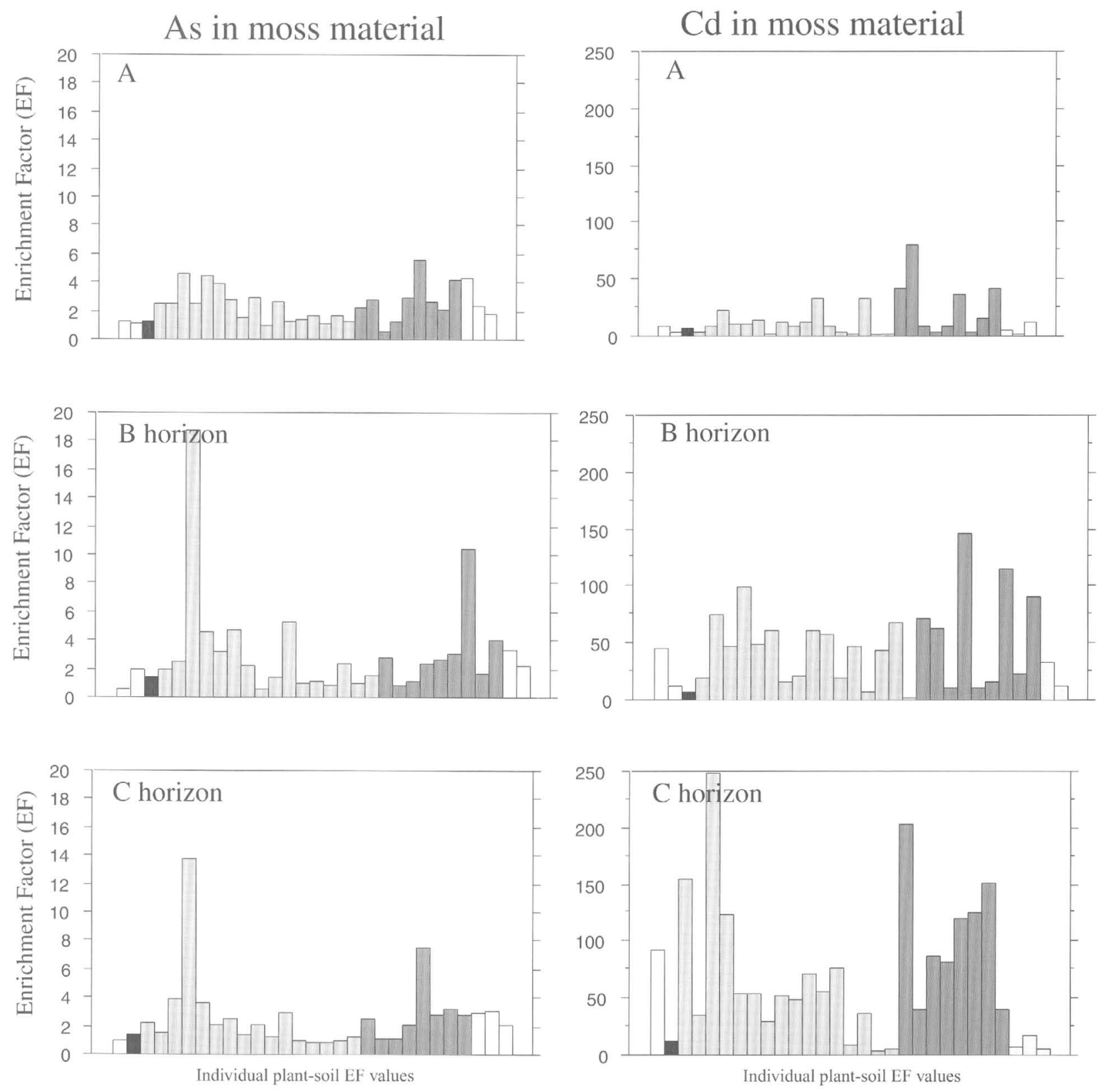

$\square$ ma $\square$ md $\square$ ms $\square$ mv $\square$ sct

Major rock units (keyed to fig. 2)

Figure 10. Enrichment factors for arsenic and cadmium in moss material for $A, B$, and $C$ soil horizons developed over five major rock units.

recorded for the uppermost soil horizon. This means that moss contains less arsenic and cadmium when compared to soil, especially when compared to A-horizon soil. In contrast, moss contains more arsenic and cadmium when compared to deeper soils. The quantity of these elements in moss is therefore most like the A horizon. This fact is consistent with the notion that moss chemistry commonly reflects material most likely to be wind-transported.

\section{Summary and Conclusions}

We report on the bioavailability of arsenic and cadmium in the boreal forests of east-central Alaska as it relates to bedrock geology and soils. Three plant species (five plant tissue materials) were collected along with the three major mineral soil horizons. Concentrations of total arsenic were found to increase with soil depth whereas the highest concentrations of 
cadmium were found in the uppermost soil horizons. Oxic, moderately acidic soils, such as those in our study area, favor arsenate formation which is both precipitated (by iron and aluminum) and sorbed (onto iron- and manganese-oxides). These factors would tend to immobilize arsenic and would account for its lack of upward movement (plant uptake and deposition) in the soil column. Cadmium, however, is readily leached in slightly acidic soils. Acid soils, therefore, favor cadmium dissolution and uptake by plants. Although cadmium generally does not form highly stable complexes with organic matter, it is bioconcentrated by willow, and past studies have shown that cadmium levels can be quite high in the Oa soil horizons (surface organic mat) (Gough and Crock, 1997). Our data show that cadmium is concentrated in the organic-rich upper soil horizons, implying that its occurrence is strongly affected by its bioavailability and uptake by plants.

We found essentially no difference in the concentration of cadmium in soils developed over five different lithologic units. In contrast, the concentration of arsenic did differ somewhat between lithologic units. For example, the two intrusive units differed in their B-horizon arsenic concentrations by two to four times. In addition, we found that both willow and alder growing over metavolcanic terrain were enriched in arsenic relative to the other rock units (this was true for all soil horizons). Examination of different elements, such as the rare earth elements, may prove more promising in the segregation of soils based on parent bedrock.

Willow leaf and twig material were found to be an important bioconcentrator of cadmium. High cadmium concentrations in browse has been shown to have a direct influence on ptarmigan kidney function in Colorado (Larison and others, 2000). We are not, however, implying that this necessarily has animal health implications for this study area. It may be that, although elevated, these cadmium concentrations are still well within animal tolerance levels. We note, however, that cadmium toxicity in the Colorado ptarmigan populations was associated with cadmium concentrations in willow that are similar to values we report. Additional work is needed to define both the physiological limits of cadmium uptake by willow, the soil conditions that most favor its uptake and mobility, and the levels that present health risks to animals. Regions of potential risk, if any, to animal health could then be defined.

Regional biogeochemical baseline values for arsenic and cadmium in plants and soils are presented and represent a "snapshot" for the material sampled during the study. In general, the baselines for arsenic (defined as the 95 percent expected range of the data) for plants and soils fall within the range observed for similar material collected throughout the State of Alaska. The soil cadmium concentrations are slightly higher (two to three times) in our study area when compared to values from material collected elsewhere; whereas cadmium concentrations in plant material are similar.

\section{Acknowledgments}

We thank Mitch Henning of the Alaska Department of Natural Resources, Division of Mining and Water Management, for valuable planning assistance, and the Division of Mining and Water Management for financing logistical needs. Field expertise was provided by Mitch Henning and Steve McGroarty. Field expenses were also defrayed by a generous grant from the Alaska Science and Technology Foundation (Grant \#98-1-079S). We are especially grateful to Larry and June Taylor of Eagle, Alaska, for their hospitality and for sharing their knowledge of the river and the region.

\section{References Cited}

Adriano, D.C., 1986, Trace Elements in the Terrestrial Environment: New York, Springer-Verlag, 533 p.

Ager, T., 2000, Postglacial vegetation history of the Kachemak Bay area, Cook Inlet, south-central Alaska, in Kelley, K.D., and Gough, L.P., eds., Geologic Studies in Alaska by the U.S. Geological Survey, 1998: U.S. Geological Survey Professional Paper 1615, p. 147-165.

Arbogast, B.F., ed., 1996, Analytical methods manual for the Mineral Resource Surveys Program, U.S. Geological Survey: U.S. Geological Survey Open-File Report 96-525, 248 p.

Berg, T., Royset, 0., and Steinnes, E., 1995, Moss (Hylocomium splendens) used as biomonitor of atmospheric trace element deposition-Estimation of uptake efficiencies: Atmospheric Environment, v. 29, p. 353-360.

Crock, J.G., Gough, L.P., Wanty, R.B., Day, W.C., Wang, B., Gamble, B.M., Henning, M., Brown, Z.A., and Meier, A.L., 1999, Regional geochemical results from the analyses of rock, water, soil, stream sediment, and vegetation samples-Fortymile River watershed, eastcentral, Alaska: U.S. Geological Survey Open-File Report 99-33, $82 \mathrm{p}$.

Day, W.C., Gamble, B.M., Henning, M.W., and Smith, B.D., 2000, Geologic setting of the Fortymile River Area-Polyphase deformational history within part of the eastern Yukon-Tanana Uplands of Alaska, in Kelley, K.D., and Gough, L.P., eds., Geologic Studies in Alaska by the U.S. Geological Survey, 1998: U.S. Geological Survey Professional Paper 1615, p. 65-82.

Dusel-Bacon, C., Hansen, V.L., and Scala, J.A., 1995, High-pressure amphibolite facies dynamic metamorphism and the Mesozoic tectonic evolution of an ancient continental margin, east-central Alaska: Journal of Metamorphic Geology, v. 13, p. 9-24.

Foster, H.L., 1976, Geologic map of the Eagle quadrangle, Alaska: U.S. Geological Survey Miscellaneous Investigations Series Map I-922.

Foster, H.L., and Keith, T.E.C., 1969, Geology along the Taylor Highway, Alaska: U.S. Geological Survey Bulletin 1281, $36 \mathrm{p}$.

Foster, H.L., Keith, T.E.C., and Menzie, W.D., 1994, Geology of the 
Yukon-Tanana area of east-central Alaska, in Plafker, G., and Berg, H.C., eds., 1994, The Geology of Alaska: Boulder, Colorado, The Geological Society of America, p. 205-240.

Gallant, A.L., Binnian, E.F., Omernik, J.M., and Shasby, M.B., 1995, Ecoregions of Alaska: U.S. Geological Survey Professional Paper $1567,73 p$.

Goldfarb, R.J., Farmer, G.L., Cieutat, B.A., and Meier, A.L., 1999, Majorelement, trace-element, and strontium-isotope systematics of natural waters in the Fairbanks mining district-Constraints from local geology, in Kelley, K.D., ed., Geologic Studies in Alaska by the U.S. Geological Survey, 1997: U.S. Geological Survey Professional Paper 1614, p. 139-150.

Gough, L.P., and Crock, J.G., 1997, Distinguishing between natural geologic and anthropogenic trace element sources, Denali National Park and Preserve, in Dumoulin, J.A., and Gray, J.E., eds., Geologic Studies in Alaska by the U.S. Geological Survey, 1995: U.S. Geological Survey Professional Paper 1574, p. 57-71.

Gough, L.P., Day, W.C., Crock, J.G., Gamble, B.M., and Henning, M., 1997, Placer gold mining in Alaska-Cooperative studies on the effect of suction dredge operations on the Fortymile River: U.S. Geological Survey Fact Sheet FS-155-97, 4 p.

Gough, L.P., McNeal, J.M., and Severson, R.C., 1980, Predicting native plant copper, iron, manganese, and zinc levels using DTPA and EDTA soil extractants, Northern Great Plains: Soil Science Society of America Journal, v. 44, p. 1030-1036.

Gough, L.P. and Severson, R.C., 1995, Mine-land reclamation-The fate of trace elements in arid and semi-arid areas, in Swaine, D.J., and Goodarze, F., eds., Environmental Aspects of Trace Elements in Coal: The Netherlands, Kluwer Academic Publishers, p. 275-307.

Gough, L.P., Severson, R.C., Harms, T.H., Papp, C.S.E., and Shacklette, H.T., 1991, Biogeochemistry of selected plant materials, Alaska: U.S. Geological Survey Open-File Report 91-292, 30 p.

Gough, L.P., Severson, R.C., and Jackson, L.L., 1994, Baseline element concentrations in soils and plants, Bull Island, Cape Romain National Wildlife Refuge, South Carolina, U.S.A.: Water, Air, and Soil Pollution, v. 74, p. 1-17.

Gough, L.P., Severson, R.C., and Shacklette, H.T., 1988, Element concentrations in soils and other surficial materials of Alaska: U.S. Geological Survey Professional Paper 1458, $53 \mathrm{p}$.

Gough, L.P., Shacklette, H.T., and Case, A.A., 1979, Element concentrations toxic to plants, animals, and man: U.S. Geological Survey Bulletin 1466, $80 \mathrm{p}$.

Kostohrys, J., Sterin, B.B.G., and Hammond, T., 1999, Water resources of the Fortymile National Wild and Scenic River, Alaska: Bureau of Land Management, BLM-Alaska Open-File Report 75, 64 p.

Larison, J.R., Likens, G.E., Fitzpatrick, J.W., and Crock, J.G., 2000, Cadmium toxicity among wildlife in the Colorado Rocky Mountains: Nature, v. 406, p. 181-183.

Lichte, F.E., Meier, A.L., and Crock, J.G., 1986, Determination of the rare earth elements in geological materials by inductively coupled plasma mass spectrometry: Analytical Chemistry, 59, p. 1150-1157.

Newman, M.C., and Jagoe, C.H., eds., 1996, Ecotoxicology-A Hierarchical Treatment: Boca Raton, Fla., CRC, Lewis Publishers, 411 p.
Puckett, K.J., 1988, Bryophytes and lichens as monitors of metal deposition, in Nash, T.H., and Wirth, V., eds., Lichens, Bryophytes, and Air Quality: Berlin-Stuttgart, J. Cramer, p. 231-268.

Severson, R.C., and Shacklette, H.T., 1988, Essential elements and soil amendments for plants-Sources and use for agriculture: U.S. Geological Survey Circular 1017, $48 \mathrm{p}$

Smith, K.S., and Huyck, H.L.O., 1999, An overview of the abundance, relative mobility, bioavailability, and human toxicity of metals, in Plumlee, G.S., and Logsdon, J.J., eds., The Environmental Geochemistry of Mineral Deposits, Part A. Processes, Techniques, and Health Issues: Society of Economic Geologists, Reviews in Economic Geology, v. 6A, p. 29-70.

Smith, M., Thompson, J.F.H., Bressler, J., Layer, P., Mortensen, J.K., Abe, I., and Takaoka, H., 1999, Geology of the Liese Zone, Pogo property, east-central Alaska: Society of Economic Geologists Newsletter, no. 38, p. 11-21.

Szumigala, D.J., Newberry, R.J., Werdon, M.B., Finseth, B.A., and Pinney, D.J., 2000, Preliminary geologic map of a portion of the Fortymile mining district, Alaska, 1999: Alaska Division of Geological and Geophysical Surveys Preliminary Interpretative Report 2000-6, 1 sheet, scale 1:63,360.

Szumigala, D.J., and Swainbank, R.C., 1999, Alaska's mineral industry-1998: Alaska Department of Natural Resources, Division of Geological and Geophysical Surveys Special Report 53, 71 p.

Tidball, R.R., and Ebens, R.J., 1976, Regional geochemical baselines in soils of the Powder River Basin, Montana-Wyoming, in Laudon, R.B., ed., Geology and Energy Resources of the Powder River Basin: Cheyenne, Wyoming, Wyoming Geological Association, 28th Annual Field Conference Guidebook, p. 299-310.

Van Cleve, K., Dyrness, C.T., Viereck, L.A., Fox, J., Chapin, F.S., III, and Dechel, W., 1983, Tiaga ecosystems in interior Alaska: BioScience, v. 33, p. 39-44.

Viereck, L.A., and Little, E.L., 1972, Alaska trees and shrubs: U.S. Department of Agriculture, Forest Service, Agricultural Handbook $410,265 p$.

Wanty, R.B., Wang, B., and Vohden, J., 1997, Studies of suction dredge gold-placer mining operations along the Fortymile River, eastern Alaska: U.S. Geological Survey Fact Sheet 154-97.

Wanty, R.B., Wang, B., Vohden, J., Briggs, P.H., and Meier, A.L., 2000, Regional baseline geochemistry and environmental effects of goldplacer mining operations on the Fortymile River, eastern Alaska, in Kelley, K.D., and Gough, L.P., eds., Geologic Studies in Alaska by the U.S. Geological Survey, 1998: U.S. Geological Survey Professional Paper 1615, p. 101-110.

Yeend, W., 1996, Gold placers of the historical Fortymile River region, Alaska: U.S. Geological Survey Bulletin 2125, 75 p.

Reviewers: C. Ager, D. Muhs 


\title{
Geochemistry of Lithologic Units, Fortymile River Study Area, East-Central Alaska
}

\author{
ByBruce M. Gamble, Warren C. Day, and Mitch W. Henning
}

\section{Introduction}

The U.S. Geological Survey and the Alaska Department of Natural Resources undertook a study of part of the Fortymile River drainage in 1997 and 1998 because of concerns that suction dredge gold mining was impacting river water quality. A multidisciplinary team of geologists, hydrologists, chemists, and botanists from the two agencies sampled the water, rock, soil, stream sediment, and vegetation in the area to determine background levels of elements in these materials. A second objective of the study was to better understand the pathways by which these elements are exchanged between these sampled materials.

Some of the results of these investigations have been previously published or are presented in this volume (Crock and others, 1999; Day and others, 2000; Gough and others, 1997; Gough and others, this volume; Wanty and others, 1997; Wanty and others, 2000). The purpose of this report is to present a brief statistical summary of the geochemistry of rock samples collected in 1997 and 1998 and to compare that information with published data for similar rock types.

\section{Geologic Setting}

Bedrock (fig. 1) consists of amphibolite-grade metasedimentary and mafic metavolcanic rocks intruded by granitic to tonalitic plutons. The metamorphic rocks are of Paleozoic(?) age and the intrusions are, at least in part, of Jurassic age (Dusel-Bacon and others, 1995; Day and others, 2000). The metasedimentary and mafic metavolcanic rocks were originally deposited on a continental margin and (or) distal to an island arc complex. The study area is in the Taylor Mountain assemblage of the Yukon-Tanana composite terrane (Hansen and Dusel-Bacon, 1998) in east-central Alaska. Foster (1969, 1976) published geologic maps of the area but these do not delineate the metamorphic units discussed in this report. The metamorphic rocks in the study area are included in a single gneiss and schist unit (Foster, 1969) or a biotite gneiss and amphibolite unit (Foster, 1976).

Placer gold has been mined in the Fortymile region since 1886 (Yeend, 1996). Yeend hypothesized the placer gold is derived, at least in part, from high terrace gravels, but the ultimate bedrock source remains unknown. The only bedrock mineralization known in the study area are stratabound pyriterich intervals in metasedimentary rocks. These locally contain minor sphalerite and galena and are discussed in greater detail below.

Metasedimentary rocks (ms unit, fig. 1) consist of biotite schist, impure quartzite, and marble. The biotite schist and quartzite constitute end members of a continuum of compositions defined chiefly by the proportion of micaceous material. Collectively, these rocks were mapped as biotite schist in the field and that terminology is used throughout this report. Compositional layering in the biotite schist is on the order of a few to tens of centimeters. These rocks represent a metamorphosed turbidite sequence of interbedded wacke (impure quartzite) and shale (biotite schist). Mineralogy of the biotite schist unit rocks consists of, in approximate decreasing order of abundance, quartz+biotite \pm feldspar \pm white mica \pm garnet \pm epidote \pm hornblende, with accessory amounts of opaque minerals (pyrite plus others?), apatite, and zircon. Within the biotite schist are distinct stratabound, but not necessarily stratiform, iron-stained zones that contain up to 2 percent pyrite. We refer to these rocks as ferruginous biotite schist, and, although too small to show at the map scale, they are indicated on fig. 1 as sulfide-rich zones. The largest of these zones is along the North Fork of the Fortymile River. This zone has a horizontal exposure of approximately $90 \mathrm{~m}$ and a stratigraphic thickness of $60 \mathrm{~m}$. Locally these zones contain iron-stained quartz segregations that are chiefly stratiform but locally cut across foliation. These quartz segregations locally contain as much as 5 percent pyrite, sphalerite, and galena.

Marbles (included in the ms unit, fig. 1) constitute approximately 40 to 50 percent of the metasedimentary rocks. They are, in places, in clear stratigraphic contact with the biotite schist. The marbles are relatively pure, containing up to 5 percent white mica, and locally biotite, amphibole, and (or) pyrite. The marbles may be massive and thick, as much 


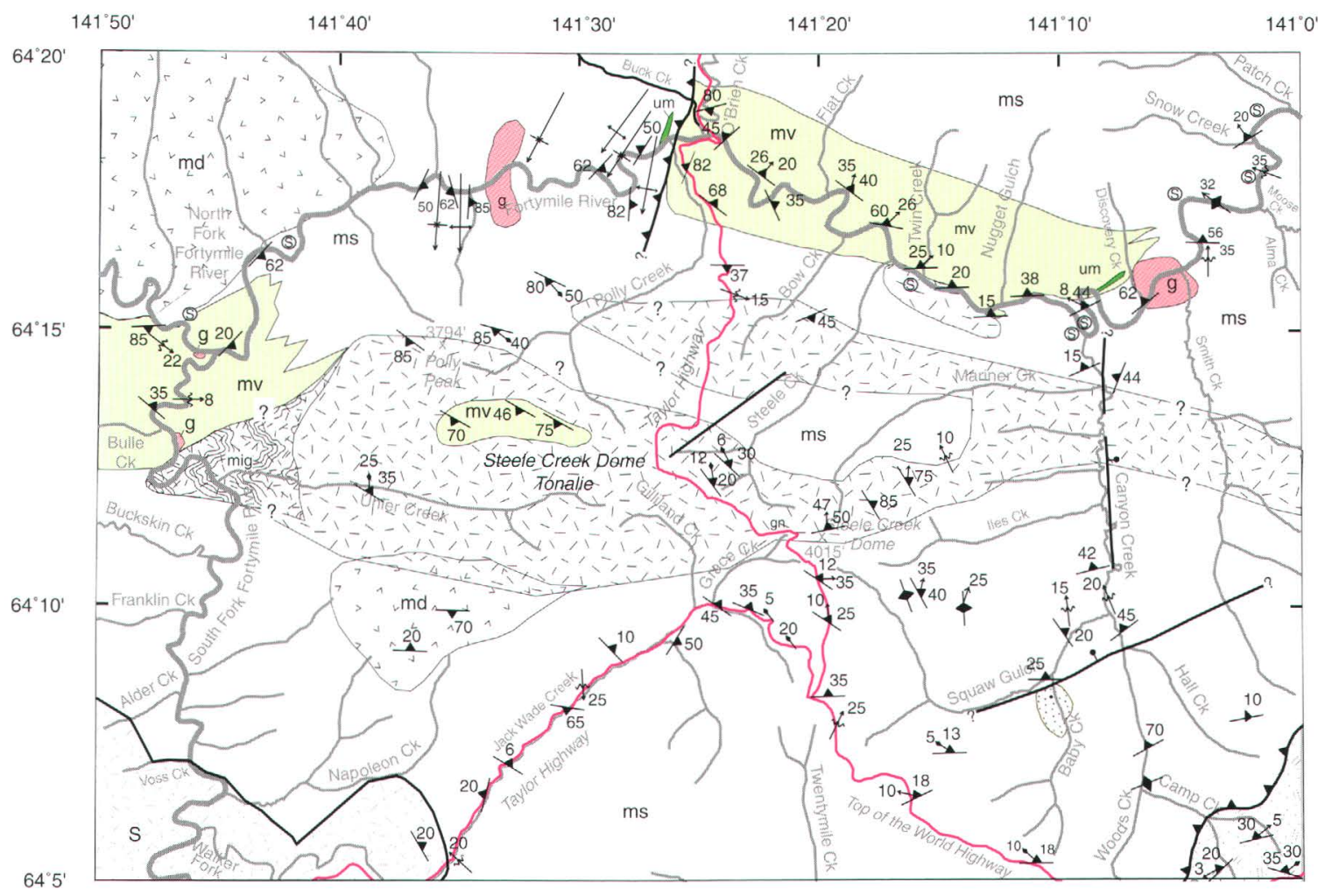

Post-tectonic intrusive rocks

Pre- to syn-tectonic intrusive rocks

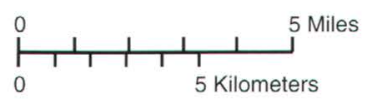

TERTIARY ROCKS

Detrital rocks of Baby Creek

INTRUSIVE ROCKS

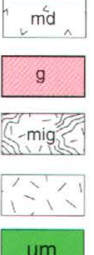

um

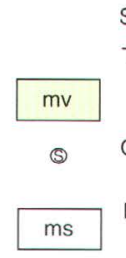

Taylor Mountain Assemblage

Metabasalt-Hornblende-biotite schist

Outcrop of sulfide-rich siliciclastic metasediment horizon within metasedimentary rock unit

Metasedimentary rocks-Biotite schist, marble,

quartzite, metapelite, sulfide-bearing siliciclastic metasediment, and minor hornblene-biotite schist
Map Symbols

18. Strike and dip of foliation

- Strike of vertical foliation

10- Trend and plunge of mineral lineation

, 15 Trend and plunge of stretching lineation

$\longleftarrow$ Trace and plunge of axis of antiform

$\longleftarrow$ Trace and plunge of axis of synform

$\longleftarrow 25$ Trend and plunge of minor fold

\section{Contact-Approximate}

Normal fault-Bar and ball on downthrown side

Thrust fault-Teeth on upper plate

Figure 1. Simplified bedrock geologic map of the Fortymile River study area. 
as several hundred meters, or thin with centimeter-scale color banding that is typically white and dark gray. Visual examination reveals no obvious mineralogical variation to account for the color layering.

Mafic metavolcanic rocks (mv, fig. 1) contain plagioclasehornblende \pm biotite \pm clinopyroxene \pm garnet \pm quartz \pm epidote and minor amounts of opaque minerals. They are fine- to mediumgrained, dark green to black, amphibolite gneisses; are of tholeiitic and calc-alkaline affinity; and are chiefly metabasalts (Day and others, 2000).

The southeast portion of the study area is underlain by a large tonalitic orthogneiss referred to informally as the Steel Creek Dome tonalite (Day and others, 2000). This orthogneiss is light gray in color, fine to medium grained, and gneissic. Feldspar augen are locally present. Although somewhat variable in composition, the orthogneiss generally consists of plagioclase, quartz, biotite, muscovite, and alkali feldspar with accessory apatite, opaque minerals, and zircon.

A large monzodiorite to diorite intrusion underlies much of the western part of the study area (fig. 1). This intrusion is fine to medium grained, seriate, and hypidiomorphic-granular or locally crudely foliated. It consists of plagioclase, clinopyroxene, biotite, quartz, alkali feldspar, and hornblende with accessory sphene, apatite, opaque minerals, and zircon.

Other rock units are present in the study area, but they are too small to show on the geologic map (fig. 1) and will not be discussed in this report.

Quartz veins occur throughout the study area, chiefly in the metasedimentary and metavolcanic units. The veins are generally thin $(3-10 \mathrm{~cm})$ and typically have limited continuity, usually less than $10 \mathrm{~m}$. They locally contain abundant calcite, and locally minor amounts of sulfide minerals, chiefly pyrite.

\section{Results}

The purpose of this section is to compare geochemical results of rock samples from the study area with published crustal abundance data for similar rock types. Rock samples were collected from each of the regional units and crosscutting quartz veins described above. In almost all instances, the sample consisted of a composite of three to five small fragments of rock collected from an exposure of the rock type of interest. All rock samples were shipped to the Denver Laboratories of the USGS for analysis. Methods of sample treatment follow the procedures described by Arbogast (1996). $\mathrm{Ag}, \mathrm{As}, \mathrm{Bi}, \mathrm{Cd}, \mathrm{Co}, \mathrm{Cr}, \mathrm{Cu}, \mathrm{Fe}, \mathrm{Ni}, \mathrm{Pb}, \mathrm{Zn}$ were analyzed by inductively coupled plasma-mass spectrometry; Au was analyzed by heated graphite furnace-atomic absorption spectrometry; $\mathrm{Hg}$ by cold vapor atomic absorption spectrometry; and total $\mathrm{S}$ by combustion infrared analysis.

Geochemical statistics for each of the regional lithologic units and the quartz veins described above are presented in table 1. A subset of all of the elements analyzed (Ag, As, $\mathrm{Au}, \mathrm{Bi}, \mathrm{Cd}, \mathrm{Cr}, \mathrm{Co}, \mathrm{Cu}, \mathrm{Fe}, \mathrm{Hg}, \mathrm{Ni}, \mathrm{Pb}, \mathrm{S}$, and $\mathrm{Zn}$ ) are presented here because they are of greatest environmental and economic interest. The data consists of both 1997 and 1998 samples. A complete listing of 1997 and 1998 sample data and a discussion of analytical methods and lower limits of analytical determination is published in Crock and others (1999, 2000).

Crustal abundance data for the elements discussed in this report are presented in table 2. One difficulty of using published crustal abundance information is the lack of data for some of the specific rock types found in the study area. For example, crustal abundance data are available for basalts and granites but not for metamorphosed mafic volcanic rocks or for tonalitic orthogneiss. Thus, compromises are made here to compare our rock samples with published data. For example, one compromise is to compare metamorphosed rocks to unmetamorphosed equivalents (e.g., metamorphosed mafic volcanic rocks with basalt), but this begs the obvious question of chemical changes during metamorphism. Another compromise is to extrapolate between compositions. For example, extrapolation between a sandstone and a shale is made to approximate a pelitic biotite schist. Given these caveats, succeeding paragraphs will discuss each lithologic unit.

\section{Biotite Schist}

The statistical summary for rock samples from this unit (table 1) shows that most analytical results are well within what would be expected from crustal abundance information for rocks derived from shale or pelite with lesser amounts of sandstone (table 2). Two interesting features emerge. Four samples contain relatively higher than expected (compared to published crustal abundance data) $\mathrm{Ag}$ values, ranging from 0.29 to $0.90 \mathrm{ppm}$. Six samples contain higher than expected total Fe content, ranging from 5.1 to 12 percent.

The higher than expected total Fe and the lack of corresponding higher total $\mathrm{S}$ suggests that most of the $\mathrm{Fe}$ is probably in the form of ferromagnesian minerals, chiefly biotite, rather than in pyrite.

\section{Ferruginous Biotite Schist}

Exposures of ferruginous biotite schist were sampled although they were too small to map apart from the main biotite schist. The analytical results are compared to the same crustal abundance data (shale, pelite, sandstone) as the main biotite schist. Three samples have higher than expected total Fe content. Three samples have higher than expected As content-one at $23 \mathrm{ppm}$ and, more notably, one each at 100 and $230 \mathrm{ppm}$. Three samples in this unit have higher $\mathrm{Hg}$ content, 0.18 to $0.42 \mathrm{ppm}$, the highest of any lithologic unit in the study area and higher than the quartz veins. Four samples have higher $\mathrm{Ag}$ values than expected compared to crustal abundance data.

The higher $\mathrm{Fe}$ values in the ferruginous biotite schist 
Table 1. Summary statistical data for selected elements in rock samples from the Fortymile River study area, Alaska.

[*, not calculated because of presence of censored values. Detection ratio is ratio of number of samples with values above the lower determination limit to the total number of samples]

\begin{tabular}{lccccc}
\hline \multicolumn{1}{c}{ Element } & Detection ratio & Minimum & Maximum & Arithmetic mean & $\begin{array}{c}\text { Standard } \\
\text { deviation }\end{array}$ \\
\hline \multicolumn{7}{c}{ Bgotite Schist } \\
\hline As, ppm & $17: 17$ & 0.02 & 0.9 & 0.16 & 0.2 \\
$\mathrm{Au}, \mathrm{ppm}$ & $13: 17$ & $<0.1$ & 3 & $*$ & $*$ \\
$\mathrm{Bi}, \mathrm{ppm}$ & $11: 17$ & $<0.005$ & 0.013 & $*$ & $*$ \\
$\mathrm{Cd}, \mathrm{ppm}$ & $12: 17$ & $<0.05$ & 0.76 & $*$ & $*$ \\
$\mathrm{Co}, \mathrm{ppm}$ & $11: 17$ & $<0.01$ & 0.2 & $*$ & $*$ \\
$\mathrm{Cr}, \mathrm{ppm}$ & $17: 17$ & 4.4 & 59 & 22 & 17 \\
$\mathrm{Cu}, \mathrm{ppm}$ & $17: 17$ & 4 & 580 & 77 & 123 \\
$\mathrm{Fe}, \%$ & $17: 17$ & 6 & 68 & 35 & 23 \\
$\mathrm{Hg}, \mathrm{ppm}$ & $17: 17$ & 1.2 & 12 & 4.8 & 3 \\
$\mathrm{Ni}, \mathrm{ppm}$ & $5: 17$ & $<0.02$ & 0.04 & $*$ & $*$ \\
$\mathrm{~Pb}, \mathrm{ppm}$ & $17: 17$ & 3.9 & 190 & 37 & 41 \\
Total S, \% & $17: 17$ & 1.7 & 28.3 & 9.9 & 6.5 \\
$\mathrm{Zn}, \mathrm{ppm}$ & $9: 17$ & $<0.03$ & 0.72 & $*$ & $*$ \\
& $17: 17$ & 31.5 & 170 & 79.3 & 37 \\
\hline \multicolumn{1}{c}{ Element } & Detection ratio & Minimum & Maximum & Arithmetic mean & Standard \\
& & & & deviation \\
\hline
\end{tabular}

\begin{tabular}{ccccc}
\hline Detection ratio & Minimum & Maximum & Arithmetic mean & $\begin{array}{c}\text { Standard } \\
\text { deviation }\end{array}$ \\
\hline \multicolumn{5}{c}{ Marble } \\
\hline $4: 6$ & $<0.02$ & 0.17 & $*$ & $*$ \\
$6: 6$ & 0.05 & 8.6 & 2.9 & 2.8 \\
$3: 6$ & $<0.005$ & 0.016 & $*$ & $*$ \\
$0: 6$ & $<0.05$ & $<0.05$ & $*$ & $*$ \\
$6: 6$ & 0.1 & 0.5 & 0.3 & 0.1 \\
$4: 6$ & $<0.1$ & 7 & $*$ & $*$ \\
$6: 6$ & 7 & 51 & 17 & 15 \\
$4: 6$ & $<3$ & 38 & $*$ & $*$ \\
$6: 6$ & 0.27 & 1.8 & 0.58 & .50 \\
$2: 6$ & $<0.02$ & 0.03 & $*$ & 8.2 \\
$6: 6$ & 3.9 & 32 & 17 & 7.9 \\
$6: 6$ & 1.3 & 25 & 5.5 & $*$ \\
$5: 6$ & $<0.03$ & 0.37 & $*$ & 16 \\
$6: 6$ & 8 & 62 & 25 & Standard \\
& & & & deviation \\
\hline Detection ratio & Minimum & Maximum & Arithmetic mean & \\
\hline
\end{tabular}

\begin{tabular}{lccccc}
\hline \multicolumn{5}{c}{ Ferruginous Biotite Schist } \\
\hline $\mathrm{Ag}, \mathrm{ppm}$ & $20: 20$ & 0.06 & 0.79 & 0.25 & 0.2 \\
$\mathrm{As}, \mathrm{ppm}$ & $18: 20$ & $<0.1$ & 230 & $*$ & $*$ \\
$\mathrm{Au}, \mathrm{ppm}$ & $12: 20$ & $<0.005$ & 0.022 & $*$ & $*$ \\
$\mathrm{Bi}, \mathrm{ppm}$ & $12: 20$ & $<0.05$ & 0.74 & $*$ & $*$ \\
$\mathrm{Cd}, \mathrm{ppm}$ & $13: 20$ & $<0.1$ & 0.6 & $*$ & $*$ \\
$\mathrm{Co}, \mathrm{ppm}$ & $20: 20$ & 1.7 & 42 & 8.3 & 8.9 \\
$\mathrm{Cr}, \mathrm{ppm}$ & $20: 20$ & 3 & 120 & 45 & 35.1 \\
$\mathrm{Cu}, \mathrm{ppm}$ & $20: 20$ & 8 & 160 & 52 & 47 \\
$\mathrm{Fe}, \%$ & $20: 20$ & 0.53 & 12 & 3.2 & 2.5 \\
$\mathrm{Hg}, \mathrm{ppm}$ & $14: 20$ & $<0.02$ & 0.42 & $*$ & $*$ \\
$\mathrm{Ni}, \mathrm{ppm}$ & $20: 20$ & 1.1 & 57 & 16 & 16 \\
$\mathrm{~Pb}, \mathrm{ppm}$ & $20: 20$ & 4.3 & 26 & 10 & 6.1 \\
$\mathrm{Total} \mathrm{S}, \%$ & $19: 20$ & $<0.03$ & 3.79 & $*$ & $*$ \\
$\mathrm{Zn}, \mathrm{ppm}$ & $20: 20$ & 22.2 & 140 & 75 & 38
\end{tabular}

\begin{tabular}{ccccc}
\hline \multicolumn{5}{c}{ Mafic Metavolcanic Rocks } \\
\hline $9: 9$ & 0.03 & 0.16 & 0.09 & 0.05 \\
$5: 9$ & $<0.05$ & 6.1 & $*$ & $*$ \\
$0: 9$ & $<0.005$ & $<0.005$ & $*$ & $*$ \\
$2: 9$ & $<0.05$ & 0.1 & $*$ & $*$ \\
$6: 9$ & $<0.1$ & 0.2 & $*$ & $*$ \\
$9: 9$ & 18 & 55 & 40 & 12 \\
$9: 9$ & 17 & 1400 & 287 & 392 \\
$9: 9$ & 5 & 68 & 34 & 25 \\
$9: 9$ & 5.6 & 13 & 8.3 & 2.4 \\
$2: 9$ & $<0.02$ & 0.04 & $*$ & $*$ \\
$9: 9$ & 6.9 & 170 & 65 & 58 \\
$9: 9$ & 0.8 & 8.8 & 4.3 & 2.6 \\
$2: 9$ & $<0.03$ & 0.13 & $*$ & $*$ \\
$9: 9$ & 62 & 120 & 95 & 22
\end{tabular}


Table 1. Summary statistical data for selected elements in rock samples from the Fortymile River study area, Alaska-Continued.

\begin{tabular}{|c|c|c|c|c|c|}
\hline Element & Detection ratio & Minimum & Maximum & $\begin{array}{c}\text { Arithmetic } \\
\text { mean }\end{array}$ & $\begin{array}{l}\text { Standard } \\
\text { deviation }\end{array}$ \\
\hline \multicolumn{6}{|c|}{ Steele Creek Dome Tonalite } \\
\hline $\mathrm{Ag}, \mathrm{ppm}$ & $13: 13$ & 0.04 & 0.12 & 0.08 & 0.29 \\
\hline As, ppm & $10: 13$ & $<0.05$ & 9.3 & $*$ & $*$ \\
\hline $\mathrm{Au}, \mathrm{ppm}$ & $2: 13$ & $<0.005$ & 0.007 & $*$ & $*$ \\
\hline $\mathrm{Bi}, \mathrm{ppm}$ & $10: 13$ & $<0.05$ & 0.53 & $*$ & * \\
\hline $\mathrm{Cd}, \mathrm{ppm}$ & $3: 13$ & $<0.1$ & 1.3 & $*$ & $*$ \\
\hline Co, ppm & $13: 13$ & 0.2 & 11 & 5.7 & 3.7 \\
\hline $\mathrm{Cr}, \mathrm{ppm}$ & $12: 13$ & 1 & 170 & $*$ & $*$ \\
\hline $\mathrm{Cu}, \mathrm{ppm}$ & $9: 13$ & 3 & 44 & $*$ & $*$ \\
\hline $\mathrm{Fe}, \%$ & $13: 13$ & 0.31 & 4.5 & 2.2 & 1.1 \\
\hline $\mathrm{Hg}, \mathrm{ppm}$ & $2: 13$ & $<0.02$ & 0.07 & $*$ & $*$ \\
\hline $\mathrm{Ni}, \mathrm{ppm}$ & $13: 13$ & 0.8 & 26 & 8.5 & 7.5 \\
\hline $\mathrm{Pb}, \mathrm{ppm}$ & $13: 13$ & 5.7 & 43 & 17 & 10 \\
\hline Total S, \% & $4: 13$ & $<0.03$ & 0.1 & $*$ & $*$ \\
\hline $\mathrm{Zn}, \mathrm{ppm}$ & $13: 13$ & 30 & 88 & 45 & 15 \\
\hline Element & Detection ratio & Minimum & Maximum & $\begin{array}{c}\text { Arithmetic } \\
\text { mean }\end{array}$ & $\begin{array}{l}\text { Standard } \\
\text { deviation }\end{array}$ \\
\hline \multicolumn{6}{|c|}{ Quartz Veins } \\
\hline $\mathrm{Ag}, \overline{\mathrm{ppm}}$ & $17: 21$ & $<0.02$ & 0.35 & $*$ & $*$ \\
\hline As, ppm & $17: 21$ & $<0.05$ & 170 & $*$ & $*$ \\
\hline $\mathrm{Au}, \mathrm{ppm}$ & $14: 21$ & $<0.005$ & 0.044 & $*$ & $*$ \\
\hline $\mathrm{Bi}, \mathrm{ppm}$ & $11: 21$ & $<0.05$ & 1.1 & $*$ & $*$ \\
\hline $\mathrm{Cd}, \mathrm{ppm}$ & $13: 21$ & $<0.1$ & 1.6 & * & $*$ \\
\hline Co, ppm & $21: 21$ & 0.1 & 37 & 8.7 & 13 \\
\hline $\mathrm{Cr}, \mathrm{ppm}$ & $19: 21$ & $<1$ & 380 & $*$ & $*$ \\
\hline $\mathrm{Cu}, \mathrm{ppm}$ & $17: 21$ & $<3$ & 340 & $*$ & * \\
\hline $\mathrm{Fe}, \%$ & $21: 21$ & 0.032 & 9 & 2.1 & 2.3 \\
\hline $\mathrm{Hg}, \mathrm{ppm}$ & $12: 21$ & $<0.02$ & 0.16 & $*$ & $*$ \\
\hline $\mathrm{Ni}, \mathrm{ppm}$ & $20: 21$ & $<1$ & 140 & $*$ & $*$ \\
\hline $\mathrm{Pb}, \mathrm{ppm}$ & $21: 21$ & 0.2 & 1700 & 80 & 362 \\
\hline Total S, \% & $13: 21$ & $<0.03$ & 1.99 & $*$ & $*$ \\
\hline $\mathrm{Zn}, \mathrm{ppm}$ & $18: 21$ & $<3$ & 240 & * & * \\
\hline
\end{tabular}

\begin{tabular}{ccccc}
\hline Detection ratio & Minimum & Maximum & $\begin{array}{c}\text { Arithmetic } \\
\text { mean }\end{array}$ & $\begin{array}{c}\text { Standard } \\
\text { deviation }\end{array}$ \\
\hline \multicolumn{5}{c}{} \\
\hline $4: 4$ & 0.1 & 0.56 & 0.25 & .19 \\
$4: 4$ & 0.5 & 5.4 & 2.9 & 2.3 \\
$1: 4$ & $<0.005$ & 0.24 & $*$ & $*$ \\
$2: 4$ & $<0.5$ & 0.1 & $*$ & $*$ \\
$1: 4$ & $<0.1$ & 0.1 & $*$ & \\
$4: 4$ & 14 & 17 & 15 & 1.1 \\
$4: 4$ & 9 & 57 & 29 & 18 \\
$4: 4$ & 4 & 20 & 9.2 & 6.4 \\
$4: 4$ & 3.8 & 5.1 & 4.5 & 3.8 \\
$1: 4$ & $<0.02$ & 0.02 & $*$ & $*$ \\
$4: 4$ & 5 & 14 & 9.1 & 3.2 \\
$4: 4$ & 8.1 & 10 & 8.7 & 0.8 \\
$2: 4$ & $<0.03$ & 0.07 & $*$ & $*$ \\
$4: 4$ & 61 & 97 & 75 & 15
\end{tabular}


Table 2. Crustal abundance data compiled from published litrerature.

[All values in parts per million unless otherwise noted]

\begin{tabular}{|c|c|c|c|c|c|}
\hline & Basalt & Granodiorite & Granite & Shale & Limestone \\
\hline & \multicolumn{5}{|c|}{ Levinson (1974), table 2-1 } \\
\hline $\mathrm{Ag}$ & 0.1 & 0.07 & 0.04 & 0.05 & 1 \\
\hline As & 2 & 2 & 1.5 & 15 & 2.5 \\
\hline $\mathrm{Au}$ & 0.004 & 0.004 & 0.004 & 0.004 & 0.005 \\
\hline $\mathrm{Bi}$ & 0.15 & - & 0.1 & 0.18 & - \\
\hline $\mathrm{Cd}$ & 0.2 & 0.2 & 0.2 & 0.2 & 0.1 \\
\hline $\mathrm{Co}$ & 50 & 10 & 1 & 20 & 4 \\
\hline $\mathrm{Cr}$ & 200 & 20 & 4 & 100 & 10 \\
\hline $\mathrm{Cu}$ & 100 & 30 & 10 & 50 & 15 \\
\hline $\mathrm{Fe}-\%$ & - & - & - & - & - \\
\hline $\mathrm{Hg}$ & 0.08 & 0.08 & 0.08 & 0.5 & 0.05 \\
\hline $\mathrm{Ni}$ & 150 & 20 & 0.5 & 70 & 12 \\
\hline $\mathrm{Pb}$ & 5 & 15 & 20 & 20 & 8 \\
\hline$S$ & - & - & - & - & - \\
\hline \multirow[t]{3}{*}{$\mathrm{Zn}$} & 100 & 60 & 40 & 100 & 25 \\
\hline & Basalts & Granite & Slates & Sandstone & Carbonates \\
\hline & \multicolumn{5}{|c|}{ Roesler (1972), table 95} \\
\hline $\mathrm{Ag}$ & 0.1 & 0.037 & 0.07 & $.0 \mathrm{X}$ & $.0 \mathrm{X}$ \\
\hline As & 2 & 1.5 & 13 & 1 & 1 \\
\hline $\mathrm{Au}$ & 0.004 & 0.004 & $.00 \mathrm{X}$ & $.00 \mathrm{X}$ & $.00 \mathrm{X}$ \\
\hline $\mathrm{Bi}$ & 0.007 & - & - & 0.01 & \\
\hline $\mathrm{Cd}$ & 0.22 & 0.1 & 0.3 & $.0 \mathrm{X}$ & 0.35 \\
\hline Co & 48 & 5 & 19 & 0.3 & 0.1 \\
\hline $\mathrm{Cr}$ & 170 & 25 & 90 & 35 & 11 \\
\hline $\mathrm{Cu}$ & 87 & 20 & 45 & $X$ & 4 \\
\hline $\mathrm{Fe}-\%$ & 8.65 & 2.7 & 4.7 & 0.98 & 0.38 \\
\hline $\mathrm{Hg}$ & 0.09 & 0.8 & 0.4 & 0.003 & 0.004 \\
\hline $\mathrm{Ni}$ & 130 & 8 & 68 & 2 & 20 \\
\hline $\mathrm{Pb}$ & 6 & 20 & 20 & 7 & 9 \\
\hline$S$ & 300 & 400 & 2400 & 240 & 1200 \\
\hline $\mathrm{Zn}$ & 105 & 60 & 95 & 15 & 20 \\
\hline
\end{tabular}

\begin{tabular}{|c|c|c|c|c|}
\hline & Pelitic rock & Granite & Basalt & Shale \\
\hline & \multicolumn{4}{|c|}{ CRC (1982), tables 98, 99} \\
\hline $\mathrm{Ag}$ & 0.07 & 0.04 & 0.1 & 0.1 \\
\hline As & 10 & 1.5 & 2 & 6.6 \\
\hline $\mathrm{Au}$ & 0.005 & - & - & - \\
\hline $\mathrm{Bi}$ & 0.1 & 0.18 & 0.15 & 0.01 \\
\hline $\mathrm{Cd}$ & 0.8 & 0.2 & 0.2 & 0.3 \\
\hline $\mathrm{Co}$ & 19 & 1 & 48 & 20 \\
\hline $\mathrm{Cr}$ & 90 & 4 & 200 & 100 \\
\hline $\mathrm{Cu}$ & 45 & 10 & 100 & 57 \\
\hline $\mathrm{Fe}-\%$ & - & 2.7 & 8.6 & 4.7 \\
\hline $\mathrm{Hg}$ & 0.4 & 0.08 & 0.08 & 0.4 \\
\hline $\mathrm{Ni}$ & 68 & 0.5 & 150 & 95 \\
\hline $\mathrm{Pb}$ & 20 & 20 & 5 & 20 \\
\hline $\mathrm{S}$ & 2400 & 270 & 250 & 220 \\
\hline \multirow[t]{3}{*}{$\mathrm{Zn}$} & 95 & 40 & 100 & 80 \\
\hline & Sandstone & Shale & Carbonate & \\
\hline & \multicolumn{3}{|c|}{ Brownlow (1979), table 7-3 } & \\
\hline $\mathrm{Ag}$ & - & 0.18 & - & \\
\hline As & $1.1-4.3$ & $6.4-9.0$ & $.74-2.5$ & \\
\hline $\mathrm{Au}$ & - & - & - & \\
\hline $\mathrm{Bi}$ & - & - & - & \\
\hline $\mathrm{Cd}$ & - & - & - & \\
\hline $\mathrm{Co}$ & $1.6-7.4$ & $4.8-13$ & $1.3-7.1$ & \\
\hline $\mathrm{Cr}$ & $2.0-39$ & $62-130$ & $2.7-29$ & \\
\hline $\mathrm{Cu}$ & $1.2-8.4$ & $13-130$ & $.84-12$ & \\
\hline $\mathrm{Fe}-\%$ & $.09-1.9$ & $1.8-4.5$ & $.11-2.1$ & \\
\hline $\mathrm{Hg}$ & $.008-.016$ & $0.045-.345$ & $.022-.03$ & \\
\hline $\mathrm{Ni}$ & $1.2-18$ & $21-110$ & $2.3-16$ & \\
\hline $\mathrm{Pb}$ & $5.0-17$ & $1.0-24$ & $4.0-18$ & \\
\hline$S$ & - & - & - & \\
\hline $\mathrm{Zn}$ & $5.2-31$ & $55-82$ & $6.5-42$ & \\
\hline
\end{tabular}


unit do correspond to higher total $\mathrm{S}$ values in the same samples, confirming the field identification of pyrite in these samples. The higher As content in the ferruginous biotite schist do not correspond with higher Fe or $\mathrm{S}$ values. This suggests that the As may not be tied up in the pyrite. The reason for the higher $\mathrm{Hg}$ in some ferruginous biotite schist samples is unknown. The reason for higher $\mathrm{Ag}$ values in both the main biotite schist unit and the ferruginous zones is also unknown.

\section{Marble}

The few marble analyses (table 1) are consistent with their derivation from average limestone (table 2). One sample does contain higher than expected $\mathrm{Ag}, \mathrm{Co}, \mathrm{Cr}, \mathrm{Cu}, \mathrm{Fe}$, and total S. This sample was collected near an apophysis of the diorite intrusion. Within this marble exposure were layers of biotite-pyroxene-epidote(?) skarn. Although the marble sample did not appear to contain skarn mineralization, the analytical data suggests that it may have been affected by heat or fluids from the nearby intrusion.

\section{Mafic Metavolcanic Rocks}

With the exception of two samples with slightly higher than expected As content, and one with higher $\mathrm{Cr}$ content, these samples fall well within crustal abundance data for basalts (table 2).

\section{Steel Creek Dome Tonalite}

The statistical summary for the tonalitic orthogneiss (table 1) can be compared to crustal abundance data for granodiorite data listed in table 2. Most analytical data fall well within predicted values. Two samples contain higher than expected As content; one of these also contains higher $\mathrm{Cd}, \mathrm{Cr}$, and total $\mathrm{S}$.

\section{Monzodiorite/Diorite Intrusion}

Crustal abundance values for granodiorite (table 2) also correspond well to analytical results for this intrusion. One sample does contain higher than expected Ag; two contain slightly higher As; and one contains higher Au.

\section{Quartz Veins}

Table 1 also summarizes analytical results for quartz vein samples. Because of their highly variable character, crustal abundance information is lacking. Perhaps the most interesting sample contains the highest $\mathrm{Au}, \mathrm{Bi}, \mathrm{Pb}$, and $\mathrm{Zn}$ values of all samples from this area. This was a thin, 3- to $5-\mathrm{cm}$ vein in a 20 - to $30-\mathrm{cm}$-wide fracture zone within the mafic metavolcanic unit. The vein contained less than 1 percent sulfide minerals, identified as pyrite in the field. Analytical results suggest that there are trace amounts of other sulfide minerals in this vein. There are a few other samples in this unit that contain slightly to moderately high $\mathrm{As}, \mathrm{Cu}$, total $\mathrm{Fe}, \mathrm{Hg}$, and total $\mathrm{S}$, again reflecting the possible presence of trace amounts of other sulfide minerals.

\section{Summary}

Trace element rock geochemistry data for the Fortymile River study area, for the most part, matches well with worldwide crustal abundance values for rocks of similar composition. Exceptions are mostly isolated single values that are only slightly higher than published data. The few trends shown by higher than expected values were chiefly $\mathrm{Ag}$ and $\mathrm{Fe}$ in both biotite schist units and $\mathrm{Hg}$ in the ferruginous biotite schist. These values, however, are also only slightly higher than published abundance data and represent relatively small proportions of the total sample population for the units.

Companion parts of this study of the Fortymile River drainage have reached similar conclusions. River water contains low amounts of total dissolved solids, and in only two cases did any element, $\mathrm{Fe}$, exceed secondary drinking-water limits (Wanty and others, 1999). Similarly, the levels of arsenic and cadmium, two elements of environmental concern, were found to be below or only slightly above levels for similar vegetation and soil materials found elsewhere in Alaska (Gough and others, this volume).

\section{References Cited}

Arbogast, B.F., ed., 1996, Analytical methods manual for the Mineral Resource Surveys Program: U.S. Geological Survey Open-File Report 96-525, $248 \mathrm{p}$.

Brownlow, A.H., 1979, Geochemistry: Englewood, N.J., Prentice Hall, $498 \mathrm{p}$.

Carmichael, R.S., ed., 1982, Handbook of Physical Properties of Rocks, v. 1: Boca Raton, Florida, CRC Press, $404 \mathrm{p}$.

Crock, J.G., Gough, L.P., Wanty, R.B., Day, W.C., Wang, Bronwen, Gamble, B.M., Brown, Z.A., and Meier, A.L., 1999, Regional geochemical results from the analyses of rock, water, soil, stream sediment, and vegetation samples-Fortymile River Watershed, eastcentral Alaska: U.S. Geological Survey Open-File Report 99-33, $82 \mathrm{p}$. 
Crock, J.G., Gough, L.P., Wanty, R.B., Day, W.C., Wang, Bronwen, Gamble, B.M., Henning, B.M., Brown, Z.A., and Meier, A.L., 2000, Regional geochemical results from the analysis of rock, water, soil, stream sediment, and vegetation samples-Fortymile River Watershed, east-central Alaska: U.S. Geological Survey Open-File Report 00-511, $157 \mathrm{p}$.

Day, W.C. Gamble, B.M., Henning, M.W., and Smith, B.D., 2000, Geologic setting of the Fortymile River area-Polyphase deformational history within part of the eastern Yukon-Tanana uplands of Alaska, in Kelley, K.D., and Gough, L.P., eds., Geologic Studies in Alaska by the U.S. Geological Survey, 1998: U.S. Geological Survey Professional Paper 1615, p. 65-82.

Foster, H.L., 1969, Reconnaissance geology of the Eagle A-1 and A-2 quadrangles, Alaska: U.S. Geological Survey Bulletin 1271-G, 30 p., 1 plate, scale 1:63,360.

Foster, H.L., 1976, Geologic map of the Eagle quadrangle, Alaska: U.S. Geological Survey Miscellaneous Investigations Map 1-922, 1 plate, scale 1:250,000.

Gough, L.P., Day, W.C., Crock, J.G., Gamble, B.M., and Henning, M.W., 1997, Placer gold mining in Alaska-Cooperative studies on the effect of suction dredge operations on the Fortymile River: U.S. Geological Survey Fact Sheet FS-155-97, 4 p.

Hansen, V.L., and Dusel-Bacon, Cynthia, 1998, Structural and kinematic evolution of the Yukon-Tanana upland tectonites, east-central Alaska-A record of late Paleozoic to Mesozoic crustal assemble: Geological Society of America Bulletin v. 110, p. 211-230.
Levinson, A.A., 1974, Introduction to exploration geochemistry: Wilmette, Illinois, Applied Publishing Ltd., 924 p.

Roesler, H.J., and Lange, H., 1972, Geochemical tables: The Netherlands, Elsevier Publishing Co., $468 \mathrm{p}$.

Wanty, R.B., Wang, Bronwen, and Vohden, Jim, 1997, Studies of suction dredge gold-placer mining operations along the Fortymile River, eastern Alaska: U.S. Geological Survey Fact Sheet FS-154-97, $2 \mathrm{p}$.

Wanty, R.B., Wang, Bronwen, Vohden, Jim, Briggs, P.H., and Meier, A.H., 2000, Regional baseline geochemistry and environmental effects of gold placer mining operations on the Fortymile River, eastern Alaska, in Kelley, K.D., and Gough, L.P., eds., Geologic Studies in Alaska by the U.S. Geological Survey, 1998: U.S. Geological Survey Professional Paper 1615, p. 101-110.

Yeend, Warren, 1996, Gold placers of the historical Fortymile River region, Alaska: U.S. Geological Survey Bulletin 2125, 75 p.

Reviewers: E. Bailey, J. Schmidt 


\title{
U.S. Geological Survey Reports on Alaska Released in 1999
}

\author{
Compiled by John P. Galloway
}

[Some reports dated 1997 did not become available until 1999; they are included in this listing]

Barnes, D.F., [1999], Gravity changes during the 26 years following the 1964 Alaskan earthquake, in Kelley, K.D., ed., Geologic Studies in Alaska by the U.S. Geological Survey, 1997: U.S. Geological Survey Professional Paper 1614, p. 115-122.

Bender, D.A., Zogorski, J.S., Halde, M.J., and Rowe, B.L., 1999, Selection procedure and salient information for volatile organic compounds emphasized in the National Water-Quality Assessment Program: U.S. Geological Survey Open-File Report 99-182, 32 p.

Brabets, T.P., Nelson, G.L., Dorava, J.M., and Milner, A.M., 1999, Water-quality assessment of the Cook Inlet basin, Alaska: Environmental setting: U.S. Geological Survey Water-Resources Investigations Report 99-4025, 66 p.

Bradley, D.C., Kusky, T.M., Haeussler, P.J., Karl, S.M., and Donley, D.T., 1999, Geologic map of the Seldovia quadrangle, south-central Alaska: U.S. Geological Survey Open-File Report 99-18, 1 sheet, scale 1:250,000 [color].

Bundtzen, Tom, 1999, Alaska Resource data file, McGrath quadrangle: U.S. Geological Survey Open-File Report 99-357, 199 p.

Cameron, Cheryl, 1999, Alaska Resource data file, Tanacross quadrangle: U.S. Geological Survey Open-File Report 99-358, 69 p.

Casadevall, T.J., Thompson, T.B., and Fox, Tom, 1999, World map of volcanoes and principle aeronautical features: U.S. Geological Survey Geologic Investigations Series Map I-2700, 1 sheet, scale 1:34,268,000 at the Equator (Mercator Projection), 12 p. [Pages are designed to be placed over the English text and warning chart, $p$. 1-4 Spanish, p. 5-8 French, and p. 9-12 Russian]

Claar, D.V., and Lilly, M.R., 1999, Workplan for U.S. Geological Survey hydrologic data-collection and support activities on Fort Wainwright, Alaska, 1994-97: U.S. Geological Survey Open-File Report 99-80, 125 p., 5 pieces.

Crock, J.G., Gough, L.P., Wanty, R.B., Day, W.C., Wang, B., Gamble, B.M., Henning, M., Brown, Z.A., and Meier, A.L., 1999, Regional geochemical results from the analyses of rock, water, soil, stream sediment, and vegetation samples-Fortymile River watershed, eastcentral Alaska: U.S. Geological Survey Open-File Report 99-33, $82 \mathrm{p}$.

Dorava, J.M., 1999, Effectiveness of stream bank-stabilization techniques along the Kenai River, Alaska: U.S. Geological Survey
Water-Resources Investigations Report WRI 99-4156, 21 p.

Dorava, J.M., and Love, Andra, 1999, Concentrations of fecal coliform bacteria in creeks, Anchorage, Alaska, August and September 1998: U.S. Geological Survey Open-File Report 99-236, 9 p.

Dorava, J.M., and Ness, Lee, 1999, Physical, chemical, and biological data for two sites on the upper Kenai River, Alaska, 1998: U.S. Geological Survey Open-File Report 99-258, 49 p.

Dumoulin, J.A., Bradley, D.C., Harris, A.G. and Repetski, J.E., [1999], Lower Paleozoic deep-water facies of the Medra area, central Alaska, in Kelley, K.D., ed., Geologic Studies in Alaska by the U.S. Geological Survey, 1997: U.S. Geological Survey Professional Paper 1614, p. 73-103.

Eppinger, R.G., Rosenkrans, Danny, and Briggs, P.H., 1999, Case study: Environmental investigation of mineral deposits in Wrangell-St. Elias National Park and Preserve, AK, in Modreski, P.J., compiler, Abstracts of the 11th Annual USGS, Central Region, 1999 Poster Review: U.S. Geological Survey Open-File Report 99-321, p. 10.

Fleming, M.D., 1999, AVHRR images for developing a circumpolar arctic vegetation map, in Markon, C.J. and Walker, D.A., eds., Proceedings of the Third International Circumpolar Arctic Vegetation Mapping Workshop: U.S. Geological Survey Open-File Report 99-551, p. 26-27.

Flores, R.M., Myers, M.D., Stricker, G.D., and Houle, J.A., [1999], Core lithofacies analysis and fluvio-tidal environments in the AK 94 CBM-1 well, near Wasilla, Alaska, in Kelley, K.D., ed., Geologic Studies in Alaska by the U.S. Geological Survey, 1997: U.S. Geological Survey Professional Paper 1614, p. 57-72.

Frenzel, S.A., and Dorava, J.M., 1999, Water-quality data for the Talkeetna River and four streams in National Parks, Cook Inlet Basin, Alaska, 1998: U.S. Geological Survey Open-File Report 99-459, 58 p.

Freymueller, J.T., 1997, Regional tectonics of southern Alaska: Extracting the "gold" from existing GPS data: U.S. Geological Survey Contract no. 1434-HQ-97-GR-03056, 9 p.

Freymueller, J.T., 1999, Measurement of active crustal motions in upper Cook Inlet and the Anchorage urban area: Final Report Award \#G03088 (NEHRP Element(s) II-U.S. Geological Survey), $12 \mathrm{p}$.

Galloway, J.P., and Toussaint, Susan, compilers, [1999], Reports on 
Alaska in non-USGS publications released in 1997 that include USGS authors, in Kelley, K.D., ed., Geologic Studies in Alaska by the U.S. Geological Survey, 1997: U.S. Geological Survey Professional Paper 1614, p. 157-160.

Galloway, J.P., and Toussaint, Susan, compilers, [1999], U.S. Geological Survey reports on Alaska released in 1997, in Kelley, K.D., ed., Geologic Studies in Alaska by the U.S. Geological Survey, 1997: U.S. Geological Survey Professional Paper 1614, p. 151-155.

Glass, R.L., 1999, Water-quality assessment of the Cook Inlet basin, Alaska-Summary of data through 1997: U.S. Geological Survey Water-Resources Investigations Report 99-4116, $110 \mathrm{p}$.

Goldfarb, R.J., Farmer, G. Lang, Cieutat, B.A., and Meier, A.L., [1999], Major-element, trace-element, and strontium-isotope systematics of natural waters in the Fairbanks mining district: Constraints from local geology, in Kelley, K.D., ed., Geologic Studies in Alaska by the U.S. Geological Survey, 1997: U.S. Geological Survey Professional Paper 1614, p. 139-150.

Gray, J.E., Lee, G.K., O'Leary, R.M., and Theodorakos, P.M., 1999, Geochemical data for stream-sediment, heavy-mineral-concentrate, and rock samples collected from the Fortyseven Creek gold-arsenic-antimony-tungsten prospect, southwestern Alaska: U.S. Geological Survey Open-File Report 99-584, 22 p.

Greninger, M.L., Klemperer, S.L., and Nokleberg, W.J., 1999, Geographic information systems (GIS) compilation of geological and geophysical data from the Circum-North Pacific, in Nokleberg, W.J. and Diggeles, M.F., eds.: U.S. Geological Survey Open-File Report 99-422, 1 CD-ROM.

Hawley, C.C., 1999, Alaska Resource data file, Yakutat quadrangle: U.S. Geological Survey Open-File Report 99-333, 30 p.

Hawley, C.C., 1999, Alaska Resource data file, Mount Fairweather quadrangle: U.S. Geological Survey Open-File Report 99-334, 204 p.

Hildreth, Wes, Fierstein, Judy, Lanphere, M.A., and Siems, D.F., [1999], Alagogshak volcano: A Pleistocene andesite-dacite stratovolcano in Katmai National Park, in Kelley, K.D., ed., Geologic Studies in Alaska by the U.S. Geological Survey, 1997: U.S. Geological Survey Professional Paper 1614, p. 105-113.

Huber, Jeff, 1999, Alaska Resource data file, Seldovia quadrangle: U.S. Geological Survey Open-File Report 99-391, $70 \mathrm{p}$.

Huber, Jeff, 1999, Alaska Resource data file, Blying Sound quadrangle: U.S. Geological Survey Open-File Report 99-392, 34 p.

Huber, Jeff, 1999, Alaska Resource data file, Kenai quadrangle: U.S. Geological Survey Open-File Report 99-393, 20 p.

Hudson, Travis, 1999, Alaska Resource data file, Bendeleben quadrangle: U.S. Geological Survey Open-File Report 99-332, 301 p.

Karl, S.M., Haeussler, P.J., and McCafferty, A.E., 1999, Reconnaissance geologic maps of the Duncan Canal/Zarembo Island area, southeastern Alaska: U.S. Geological Survey Open-File Report 99-168, 29 p., 1 sheet, scale 1:150,000.

Kelley, K.D., [1999], Introduction, in Kelley, K.D., ed., Geologic Studies in Alaska by the U.S. Geological Survey, 1997: U.S. Geological Survey Professional Paper 1614, p. 1-3.

Kelley, K.D., ed., [1999], Geologic studies in Alaska by the U.S. Geological Survey, 1997: U.S. Geological Survey Professional Paper 1614,
$160 \mathrm{p}$.

Markon, C.J., and Walker, D.A., eds., 1999, Proceedings of the Third International Circumpolar Arctic vegetation mapping workshop: U.S. Geological Survey Open-File Report 99-551, 80 p.

McGimsey, R.G., and Wallace, K.L., 1999, 1997 Volcanic activity in Alaska and Kamchataka: Summary of events and response of the Alaska Volcano Observatory: U.S. Geological Survey Open-File Report 99-448, $42 \mathrm{p}$.

Miller, Tom, 1999, Volcanic ash hazards to aviation across the North Pacific, in Guffanti, M.C. Bacon, C.R. Hanks, T.C., and Scott, W.E., eds., Proceedings of the Workshop on Present and Future Direction in Volcano-Hazard Assessments: U.S. Geological Survey Open-File Report 99-339, p. 12.

Neal, E.G., and Host, R.H., 1999, Hydrology, geomorphology, and flood profiles of the Mendenhall River, Juneau, Alaska: U.S. Geological Survey Water-Resources Investigations Report WRI 99-4150, 35 p.

Nelson, S.W., Miller, M.L., Haeussler, P.J., Snee, L.W., and Huber, Carol, 1999, Preliminary map of the Chugach National Forest Special Study Area, Alaska: U.S. Geological Survey Open-File Report 99-362, 1 sheet, scale 1:63,360 [color].

Newberry, R.J., and Brew, D.A., [1999], Chemical and isotopic data for rocks and ores in the Upper Triassic Greens Creek and Woewodski Island volcanogenic massive sulfide deposits, southeastern Alaska, in Kelley, K.D., ed., Geologic Studies in Alaska by the U.S. Geological Survey, 1997: U.S. Geological Survey Professional Paper 1614, p. 35-55.

Osterman, L.E., Poore, R.Z., and Foley, K.M., 1999, Distribution of benthic foraminifers (> $125 \mu \mathrm{m})$ in the surface sediments of the Arctic Ocean: U.S. Geological Survey Bulletin 2164, 28 p.

Parnow, C.C., Goldfarb, R.J., Kelley, K.D., and York, G.S, [1999], Metal cycling along the northwestern Seward Peninsula, Alaska: A possible natural cause of metal contamination in the Arctic, in Kelley, K.D., ed., Geologic Studies in Alaska by the U.S. Geological Survey, 1997: U.S. Geological Survey Professional Paper 1614, p. 123-137.

Rombach, Cameron, 1999, Alaska Resource data file, Big Delta quadrangle: U.S. Geological Survey Open-File Report 99-354, 145 p.

Saltus, R.W., Riggle, F.E., Clark, B.T., and Hill, P.L., 1999, Merged areoradiometric data for Alaska: A web site for distribution of gridded data and plot files: U.S. Geological Survey Open-File Report 99-16, $13 \mathrm{p}$.

Talbot, S.S., and Markon, C.J., 1999, Prototype map of southwestern Alaska for the circumpolar arctic vegetation map, in Markon, C.J. and Walker, D.A., eds., Proceedings of the Third International Circumpolar Arctic Vegetation Mapping Workshop: U.S. Geological Survey Open-File Report 99-551, p. 28.

Trabant, D.C., 1999, Perennial snow and ice volumes on Iliamna volcano, Alaska, estimated with ice radar and volume modeling: U.S. Geological Survey Water-Resources Investigations Report WRI 99-4176, $11 \mathrm{p}$.

U.S. Geological Survey, 1999, USGS program in Alaska: U.S. Geological Survey Fact Sheet 003-99, $4 \mathrm{p}$.

U.S. Geological Survey, 1999, Alaska Resource data file, Afognak quadrangle: U.S. Geological Survey Open-File Report 99-40, 15 p. 
U.S. Geological Survey, 1999, Alaska Resource data file, Trinity Island quadrangle: U.S. Geological Survey Open-File Report 99-41, 12 p.

U.S. Geological Survey, 1999, Alaska Resource data file, Karluk quadrangle: U.S. Geological Survey Open-File Report 99-42, 71 p.

U.S. Geological Survey, 1999, Alaska Resource data file, Kodiak quadrangle: U.S. Geological Survey Open-File Report 99-43, 67 p.

U.S. Geological Survey, 1999, Alaska Resource data file, Talkeetna quadrangle: U.S. Geological Survey Open-File Report 99-139, 183 p.

U.S. Geological Survey, 1999, Alaska Resource data file, Medfra quadrangle: U.S. Geological Survey Open-File Report 99-156, 16 p.

U.S. Geological Survey, 1999, Alaska Resource data file, Prince Rupert quadrangle: U.S. Geological Survey Open-File Report 99-306, 16 p.

Walker, D.A., 1999, An integrated vegetation map for northern Alaska: A prototype for circumpolar arctic vegetation mapping, in Markon, C.J. and Walker, D.A., eds., Proceedings of the Third International Circumpolar Arctic Vegetation Mapping Workshop: U.S. Geological Survey Open-File Report 99-551, p. 32.

Wang, Bronwen, 1999, Spatial distribution of chemical constituents in the Kuskokwim River, Alaska: U.S. Geological Survey WaterResources Investigations Report WRI 99-4177, 33 p.

Wanty, R.B., Wang, Bronwen, Vohden, Jim, Briggs, P.H., and Meier, A.H., 1999, Regional baseline geochemistry and environmental effects of gold placer mining operations on the Fortymile River, eastern Alaska: U.S. Geological Survey Open-File Report 99-328, $24 \mathrm{p}$.
Waythomas, C.F., and Miller, T.P., 1999, Preliminary volcano-hazard assessment for lliamna Volcano, Alaska: U.S. Geological Survey Open-File Report 99-373, 31 p., 1 sheet.

Werdon, M.B., [1999], Geologic setting of Mississippian vein-breccias at the Kady $\mathrm{Zn}-\mathrm{Pb}-\mathrm{Cu}-\mathrm{Ag}$ prospect: Plumbing system for a failed Sedex deposit, in Kelley, K.D., ed., Geologic Studies in Alaska by the U.S. Geological Survey, 1997: U.S. Geological Survey Professional Paper 1614, p. 5-34.

Wesson, R.L., Frankel, A.D, Mueller, C.S., and Harmsen, S.C., 1999, Probabilistic seismic hazard maps of Alaska: U.S. Geological Survey Open-File Report 99-36, 43 p.

Wesson, R.L., Frankel, A.D., Mueller, C.S., and Harmsen, S.C., 1999, Seismic-hazard maps for Alaska and the Aleutian Islands: U.S. Geological Survey Geologic Investigation Series I-2679, 2 sheets, scale 1:7,500,000.

Winkler, G.R., Goldfarb, R.J., Pickthorn, W.J., and Campbell, D.L., 1999, Maps showing areas of potential for metallic mineral resources in the Valdez $1^{\circ} \times 3^{\circ}$ quadrangle, Alaska: U.S. Geological Survey Geologic Investigations Series I-2652, 39 p., 1 sheet, scale 1:250,000 [color].

Wyss, Max, and Hansen, Roger, 1999, Seismicity parameters for seismic hazard assessment in Alaska: U.S. Geological Survey Contract no. 1434-HQ-97-GR-03073, 12 p. 



\title{
Reports About Alaska in Non-USGS Publications Released in 1999 that Include USGS Authors
}

\author{
Compiled by John P. Galloway
}

[USGS authors are marked with asterisks $\left(^{*}\right)$ ]

*Ager, Thomas, 1999, Late Wisconsin glacial and postglacial history of southeastern Alaska: Implications for ecosystem development and colonization by humans [abs.]: Geological Society of America, Abstracts with Programs, v. 31, no. 7, p. 367.

*Ager, T.A., 1999, Late Quaternary history of vegetation and climate change in the Mount Harper area, Yukon-Tanana upland, East-central Alaska [abs.]: AAAS, Arctic Division, Program and Abstracts50th Arctic Science Conference-Science in the North: 50 years of Change, Denali National Park and Preserve, Alaska, Sept. 19-22, 1999, p. 75.

Anderson, K.S., 1999, News from Capital Hill-Sometimes science is beside the point: Journal of Geoscience Education, v. 47, no. 4, p. 374-375. [Anderson is the 1998/99 GSA/USGS Congressional Science Fellow, the article discusses ANWR, science versus policy decisions]

*Bailey, E.A., Hines, M.E., *Gray, J.E., and *Rytuba, J.J., 1999, Mercury transformations in soils at abandoned $\mathrm{Hg}$ mines [abs.]: Geological Society of America, Abstracts with Programs, v. 31, no. 6, p. 36.

*Bolm, K.S., *Frank, D.G., and *Schneider, J.L., 1999, Three archives of the U.S. Geological Survey's Western Mineral Resources Team [abs.]: Geological Society of America, Abstracts with Programs, v. 31, no. 7, p. 163.

${ }^{*}$ Brew, D.A., 1999, Plutonic belts of southeastern Alaska (SEAK) and adjacent regions: Products of accreted arcs and continent-continent collision [abs.]: Geological Society of America, Abstracts with Programs, v. 31, no. 6, p. 40.

Bruhn, R.L., Pavlis, T.L., *Plafker, George, and Serpa, Laura, 1999, Deformation of the Yakutat microplate in the St. Elias orogen, Alaska and Canada [abs.]: Geological Society of America, Abstracts with Programs, v. 31, no. 7, p. 295.

Bundtzen, T.K., Harris, E.E., *Miller, M.L., Layer, P.W., and Laird, G.M., 1999, Geology of the Sleetmute C-7, C-8, D-7 and D-8 quadrangles, Horn Mountains, southwestern Alaska: Alaska Division of Geological and Geophysical Surveys Report of Investigations 98-12, 38 p., 1 sheet, 2 oversized tables, scale 1:63,360 [color].

${ }^{*}$ Carlson, P.R., ${ }^{*}$ Cochrane, G.R., ${ }^{*}$ Hooge, P.N., and *Taggert, S.J., 1999,
Discovery of $100+$ yr. old iceberg gouges; are they effective habitats for halibut in lower Glacier Bay, Alaska? [abs.]: Geological Society of America, Abstracts with Programs, v. 31, no. 6, p. 43.

*Carlson, P.R., Cowan, E.A., Powell, R.D. and Cai, J., 1999, Growth of post-Little Ice Age submarine fan, Glacier Bay, Alaska: Geo-Marine Letters, v. 19, no. 4, p. 227-236.

Dehn, Jonathan, Dean, Kenneson, Worley, Shelly, Izbekov, Pavel, *Schneider, Dave, Theilen, Monica, and Engel, Kevin, 1999, Thermal satellite imagery of the 1999 eruption of Shishaldin Volcano [abs.]: Eos (American Geophysical Union Transactions), v. 80, no. 16, supplement, p. 1146.

*Dorava, J.M., and *Milner, A.M., 1999, Effects of recent volcanic eruptions on aquatic habitat in the Drift River, Alaska, USA; implications at other Cook Inlet region volcanoes: Environmental Management, v. 23, no. 2, p. 217-230.

*Dusel-Bacon, Cynthia, and Cooper, K.M., 1999, Trace-element geochemistry of metabasaltic rocks from the Yukon-Tanana Upland and implications for the origin of tectonic assemblages in eastcentral Alaska: Canadian Journal of Earth Sciences, v. 36, no. 10, p. 1671-1695.

*Dutro, J.T., Jr., 1999, Geologic mapping in the Brooks Range, Alaska, 1950-1990 [abs.]: AAAS, Arctic Division, Program and Abstracts50th Arctic Science Conference-Science in the North: 50 years of Change, Denali National Park and Preserve, Alaska, Sept. 19-22, 1999, p. 173.

*Dzurisin, Daniel, *Lu, Zhong, *Wicks, Charles, and *Thatcher, Wayne, 1999, Inflation of Westdahl Volcano, Alaska, detected by satellite radar interferometry [abs.]: Eos (American Geophysical Union Transactions), v. 80, no. 16, supplement, p. 1196.

Elias, S,A., *Hamilton, T.D., Edwards, M.E., Begét, J.E., Krumhardt, A.P., and Lavoie, Claude. 1999, Late Pleistocene environments of the western Noatak Basin, northwestern Alaska: Geological Society of America Bulletin, v. 111, no. 5, p. 769-789.

Farmer, G.L., ${ }^{*}$ Goldfarb, R.J., and *Meier, A.L., 1999, Arsenic-rich ground and surface waters of the Fairbanks mining district: How do they relate to lode gold mining? [abs.]: Geological Society of 
America, Abstracts with Programs, v. 31, no. 6, p. 54.

Fountain, A.G., Walder, J.S., Anderson, S.P., Anderson, R.S., *Trabant, Dennis, Lindsay, Donald, and Cunico, Michelle, 1999, The 1999 outburst of glacier-dammed Hidden Creek Lake [abs.]: Eos (American Geophysical Union Transactions), v. 80, no. 16, supplement, p. 426.

Fruehn, Juergen, von Huene, Roland, and *Fisher, M.A., 1999, Accretion in the wake of terrane collision; the Neogene accretionary wedge off Kenai Peninsula, Alaska: Tectonics, v. 18, no. 2, p. 263-277.

Gehrels, G.E., Johnsson, M.J., and *Howell, D.G., 1999, Detrital zircon geochronology of the Adams Argillite and Nation River Formation, east-central Alaska, U.S.A.: Journal of Sedimentary Research, v. 69 , no. 1, p. 135-144. [Devonian Nation River Formation, Adams Argillite]

${ }^{*}$ Gough, L.P., Wanty, R.B., *Wang, B., *Crock, J.G., Day, W.C., *Gamble, B.M., and Henning, M.W., 1999, Regional geochemical studies related to placer gold resources, Fortymile River area, east-central Alaska [abs.]: Geological Society of America, Abstracts with Programs, v. 31, no. 6, p. 58 .

${ }^{*}$ Gray, J.E., ${ }^{*}$ Crock, J.G., *Theodoraks, P.M., and *Bailey, E.A., 1999, Historic mercury mining in Alaska and why it has not represented a significant environmental hazard [abs.]: Geological Society of America, Abstracts with Programs, v. 31, no. 6, p. 59.

Greninger, M.L., Klemperer, S.L., and *Nokleberg, W.J., 1999, Spatial data compilation of geophysical, geological, and tectonic data for the circum-North Pacific region [abs.]: Eos (American Geophysical Union Transactions), v. 80, no. 16, supplement, p. 1030.

*Haeussler, P.J., Best, Timothy, and *Waythomas, C.F., 1999, Paleoseismology of Castle Mountain fault, Alaska, from trenching studies [abs.]: Eos (American Geophysical Union Transactions), v. 80, no. 16 , supplement, p. 737

*Haeussler, P.J., *Karl, S.M., Mortensen, J.K., Layer, Paul, and Himmelberg, G.R., 1999, Permian and mid-Cretaceous deformation of the Alexander Terrane on Admiralty and Kupreanof Islands, southeastern Alaska [abs.]: Geological Society of America, Abstracts with Programs, v. 31, no. 6, p. 60.

Johnston, S.T., Mihalynuk, M.G., ${ }^{*}$ Brew, D.A., Hart, C.J.R., Erdmer, Philippe, Gehrels, G.E., Currie, L.D., and Parrish, R.R., 1999, Paleozoic and Mesozoic rocks of Stikinia exposed in northwestern British Columbia; implications for correlations in the northern Cordillera; discussion and reply: Geological Society of America Bulletin, v. 111, no. 7 , p. 1103-1106.

*Karl, S.M., *Haeussler, P.J., Mortenson, J.K., Layer, Paul, Savage, Norman, *Wardlaw, Bruce, ${ }^{*}$ Harris, Anita, ${ }^{*}$ Murchey, Bonnie, and *Blome, Charles, 1999, New stratigraphic and isotopic constraints on the depositional and deformational history of the Alexander terrane, southeastern Alaska [abs.]: Geological Society of America, Abstracts with Programs, v. 31, no. 6, p. 68.

*Karl, S.M., Zumsteg, Cathy, ${ }^{*}$ Haeussler, P.J., and Himmelberg, G.R., 1999, Slab window metamorphism of the Chugach accretionary complex, Baranof Island, southeastern Alaska [abs.]: Eos (American Geophysical Union Transactions), v. 80, no. 16, supplement, p. 1025-1026.

*Keith, T.C., Eichelberger, and Nye, C.J., 1999, The 1999 eruption of
Shishaldin Volcano, Alaska: A successful example of "remote" monitoring [abs.]: Eos (American Geophysical Union Transactions), v. 80 , no. 16 , supplement, p. 1145-1146.

*Kennedy, B.W., *Trabant, D.C., and *March, R.S., 1999, Air temperature and precipitation data for two high-altitude climate and glacier-monitoring sites in Alaska, 1968-98 [abs.]: AAAS, Arctic Division, Program and Abstracts - 50th Arctic Science ConferenceScience in the North: 50 years of Change, Denali National Park and Preserve, Alaska, Sept. 19-22, 1999, p. 78.

Kusky, T.M., and *Bradley, D.C., 1999, Kinematic analysis of mélange fabrics: Examples and applications from the McHugh complex, Kenai Peninsula, Alaska: Journal of Structural Geology, v. 21, no. 12 , p. 1773-1796

Lewchuk, M.T., Symons, D.T.A., *Leach, David, and *Kelly, K.D., 1999, Paleomagnetism of the Red Dog zinc-lead ore deposit in northern Alaska [abs.]: Eos (American Geophysical Union Transactions), v. 80, no. 16, supplement, p. 289.

*Lu, Zhong, *Wicks, Charles, and Mann, Doerte, 1999, Studying volcanoes of Alaska by satellite radar interferometry [abs.]: Eos (American Geophysical Union Transactions), v. 80, no. 16, supplement, p. 1193.

*Lu, Zhong, *Wicks, Charles, *Power, J.A., and *Dzurisin, Daniel, 1999, Deformation of Akutan Volcano, Alaska, revealed by satellite radar interferometry [abs.]: Eos (American Geophysical Union Transactions), v. 80, no. 16, supplement, p. 1196.

*Marlow, M.S., * Stevenson, A.J., *Chezar, H., and Mc Connaughey, R.A., 1999, Tidally generated sea-floor lineations in Bristol Bay, Alaska, USA: Geo-Marine Letters, v. 19, no. 4, p. 219-226.

McClelland, W.C., Kusky, T., *Bradley, D., *Dumoulin, J.A., and *Harris, A.G., 1999, The nature of "Nixon Fork basement," west-central Alaska [abs.]: Geological Society of America, Abstracts with Programs, v. 31, no. 6, p. 78.

McCoy, Dan, Dodd, Stan, Arribas, Jr., Antino, *Miller, M.L., ${ }^{*}$ Goldfarb, R.J., and Szumigala, D.J., 1999, Geology and geochemistry of the Donlin Creek Gold deposit, SW Alaska [abs.]: Geological Society of America, Abstracts with Programs, v. 31, no. 6, p. 78.

*McGimsey, R.G., *Schneider, D.J., *Neal, C.A., and Roach, A.L., 1999, Use of FLIR observations during eruption response at two Alaskan volcanoes [abs.]: Eos (American Geophysical Union Transactions), v. 80 , no. 16 , supplement, p. 1146.

*Miller, T.P., 1999, Newly identified early Holocene caldera-forming eruption from Roundtop Volcano, Unimak Island, Alaska [abs.]: Eos (American Geophysical Union Transactions), v. 80, no. 16, supplement, p. 1190.

*Miller, T.P., Chertkoff, D.G., Eichelberger, J.C., and Coombs, M.L., 1999, Mount Dutton Volcano, Alaska; Aleutian Arc analog to Unzen Volcano, Japan: Journal of Volcanology and Geothermal Research, v. 89 , nos. 1-4, p. 275-301.

*Molnia, B.F., and Sfraga, Mike, 1999, Measuring and monitoring changes in Alaska's glaciers with ground, aerial, and space photography: a history [abs.]: AAAS, Arctic Division, Program and Abstracts-50th Arctic Science Conference-Science in the North: 50 years of Change, Denali National Park and Preserve, Alaska, Sept. 19-22, 1999, p. 78-79. 
*Moore, T.E., 1999, Balanced cross section, Brooks Range to Beaufort Shelf, northeastern Arctic National Wildlife Refuge (ANWR), Alaska [abs.]: Geological Society of America, Abstracts with Programs, v. 31, no. 6, p. 81 .

*Moran, S.C., Hansen, R.A., Stihler, S.D., and Lees, J.M., 1999, A tectonic earthquake sequence preceding the April-May 1999, eruption of Shishaldin volcano, Alaska [abs.]: Eos (American Geophysical Union Transactions), v. 80, no. 16, supplement, p. 972.

*Muhs, D.R., *Ager, T.A., and Begét, J.E., 1999, Vegetation and paleoclimate of the Last Interglacial Period in central Alaska and a data-model comparison [abs.]: AAAS, Arctic Division, Program and Abstracts - 50th Arctic Science Conference-Science in the North: 50 years of Change, Denali National Park and Preserve, Alaska, Sept. 19-22, 1999, p. 76.

*Nokleberg, W.J., Bundtzen, T.K., Goryachev, N.A., Shpikerman, V.I., Khanchuk, A.I., Ratkin, V.V., and Parfenov, L.M., 1999, Metallogenesis of the Russian Far East and Alaska as part of the Circum-North Pacific tectonic regime [abs.]: Mongolian Geoscientist, no. 14, p. 89-90.

*Nokleberg, W.J., Khanchuk, A.I., Naumova, V.V., Badarch, Gombosuren, Parfenov, L.M., *Miller, R.J., and NE Asia Metallogenesis Team, 1999, Geographic information systems compilation of geodynamic, mineral resource, and geophysical maps being developed for the Northeast Asia metallogenesis project [abs.]: Mongolian Geoscientist, no. 14, p. 52-53.

*Nokleberg, W.J., ${ }^{*}$ Scholl, D.W., Khanchuk, A.I., Monger, J.W.H., Norton, I.A., and Parfenov, L.M., 1999, Late Cretaceous and Cenozoic tectonic evolution of the North Pacific Rim [abs.]: Geological Society of America, Abstracts with Programs, v. 31, no. 6, p. 83.

*Poore, R.Z., *0sterman, Lisa, Curry, W.B., and *Phillips, R.L., 1999, Late Pleistocene and Holocene meltwater events in the western Arctic Ocean: Geology, v. 27, no. 8, p. 759-762.

*Potter, C.J., *Perry, W.J., and * Grow, J.A., 1999, Style and timing of deformation in the frontal part of the northeastern Brooks Range orogen beneath the Beaufort coastal plain, Arctic National Wildlife Refuge, northeast Alaska [abs.]: Geological Society of America, Abstracts with Programs, v. 31, no. 6, p. 86.

*Saltus, R.W., Hudson, T.L., and Connard, G.G., 1999, A new magnetic view of Alaska: GSA Today, v. 9, no. 3, p. 1-6.

*Schmidt, J.M., Werdon, M.B., ${ }^{*}$ Riehle, J.R., Newberry, R.J., Pessel, G., and Clautice, K., 1999, Iron Creek geophysical tract update [abs.]: Alaska Miners Association Annual Convention, Nov. 1-6, 1999, Anchorage, Alaska, p. 4-6.

*Schmoll, H.R., Yehle, L.A., and Updike, R.G., 1999, Summary of Quaternary geology of the Municipality of Anchorage, Alaska: Quaternary International, v. 60, p. 3-36.

*Schneider, D.J., *Moran, S.C., and Nye, C.J., 1999, Volcanic clouds from the 1999 eruption of Shishaldin Volcano, Alaska: Comparisons of satellite, seismic, and geologic observations [abs.]: Eos (American Geophysical Union Transactions), v. 80, no. 16, supplement, p. 1146-1147.

${ }^{*}$ Scholl, D.W., 1999, Plate-boundary driven tectonism of the northern rim of the Pacific basin forms the Aleutian-Bering region in the Early and Middle Eocene [abs.]: Geological Society of America,
Abstracts with Programs, v. 31, no. 6, p. 92.

Scotese, C.R., *Nokleberg, W.J., ${ }^{*}$ Scholl, D.W., Bundtzen, T.K., Khanchuk, A.I., Monger, J.W.H., Dawson, K.M., Norton, I.O., and Parfenov, L.M., 1999, Metallogenic and tectonic development of the circum-north: A computer animation [abs.]: Geological Society of America, Abstracts with Programs, v. 31, no. 6, p. 93.

Scotese, C.R., *Nokleberg, W.J., ${ }^{*}$ Scholl, D.W., Bundtzen, T.K., Khanchuk, A.I., Monger, J.W.H., Dawson, K.M., Norton, I.O., and Parfenov, L.M., 1999, Computer animation and tectonic reconstruction illustrating the metallogenic development of the circum-north Pacific from the Devonian to present [abs.]: Geological Society of America, Abstracts with Programs, v. 31, no. 6, p. 93.

${ }^{*}$ Stottlemyer, Robert, and McLoone, Keather, 1999, Stream chemistry in small watersheds, Denali National Park and Preserve, AK [abs.]: AAAS, Arctic Division, Program and Abstracts-50th Arctic Science Conference-Science in the North: 50 years of Change, Denali National Park and Preserve, Alaska, Sept. 19-22, 1999, p. 196.

*Taylor, C.D., *Premo, W.R., and *Meier, A.L., 1999, The Late Triassic metallogeny of the Alexander terrane, southeastern Alaska and British Columbia [abs.]: Geological Society of America, Abstracts with Programs, v. 31, no. 6, p. 101.

*Taylor, T.E., 1999, USGS toponymic research in Alaska between 1950 and 1975 [abs.] AAAS, Arctic Division, Program and Abstracts50th Arctic Science Conference-Science in the North: 50 years of Change, Denali National Park and Preserve, Alaska, Sept. 19-22, 1999, p. 145-146.

*Till, Alison, 1999, Interagency Minerals Coordinating Group-Status report [abs.]: Alaska Miners Association Annual Convention, Nov. 1-6, 1999, Anchorage, Alaska, p. 19.

*Trabant, Dennis, 1999, Ice-dam motion during Jokulhlaup release [abs.]: Eos (American Geophysical Union Transactions), v. 80, no. 16 , supplement, p. 426.

*Trabant, D.C., and *March, R.S., 1999, Mass-balance measurements in Alaska and suggestions for simplified observations programs: Geografiska Annaler, v. 81A, no. 4, p. 777-789.

*Wallace, K.L., and *Waythomas, C.F., 1999, Geologic setting and characterization of a large volcanic debris avalanche deposit in the Copper River basin, Alaska [abs.]: Eos (American Geophysical Union Transactions), v. 80, no. 16, supplement, p. 1150.

*Waythomas, C.F., 1999, Stratigraphic framework of Holocene volcaniclastic deposits, Akutan Volcano, east-central Aleutian Islands, Alaska: Bulletin of Volcanology, v. 61, no. 3, p. 141-161.

*Waythomas, C.F., *Miller, T.P., and Begét, J.E., 1999, Record of late Holocene debris-avalanche and lahar formation at Iliamna Volcano, Alaska [abs.]: Eos (American Geophysical Union Transactions), v. 80 , no. 16 , supplement, p. 1140.

Wiles, G.C., *Post, Austin, Muller, E.H., and *Molnia, B.F., 1999, Dendrochronology and late Holocene history of Bering Piedmont Glacier, Alaska: Quaternary Research, v. 52, no. 2, p. 185-195.

*Wynn, Jeff, and *Grybeck, Donald, 1999, A new geologic interpretation of the aeromagnetic and gravity data for Prince of Wales and nearby islands, southeastern Alaska [abs.]: Alaska Miners Association Annual Convention, Nov. 1-6, 1999, Anchorage, Alaska, p. 2. 
Manuscript approved for publication December 22, 2000

Published in the Central Region, Denver, Colorado

Editing, page layout, photocomposition-Richard W. Scott, Jr.

Cover design, graphics consultation-Carol A. Quesenberry

Graphics by the authors 